\title{
Causticizing for Black Liquor Gasifiers
}

Final Project Report

October 1, 2002 - Feb 28, 2007

\author{
by \\ Scott Sinquefield \\ James Cantrell \\ Xiaoyan Zeng \\ Alan Ball \\ Jeff Empie
}

Report issued October, 2007

U.S. DOE Award \#DE-FC26-02NT41492

Institute of Paper Science and Technology at Georgia Tech 500 Tenth St. NW

Atlanta, GA 30332-0620 


\section{DISCLAIMER}

This report was prepared as an account of work sponsored by an agency of the United States Government. Neither the United States Government nor any agency thereof, nor any of their employees, makes any warranty, express or implied, or assumes any legal liability or responsibility for the accuracy, completeness, or usefulness of any information, apparatus, product, or process disclosed, or represents that its use would not infringe privately owned rights. Reference herein to any specific commercial product, process, or service by trade name, trademark, manufacturer, or otherwise does not necessarily constitute its endorsement, recommendation, or favoring by the United States Government or any agency thereof. The views and opinions of authors expressed herein do not necessarily state or reflect those of the United States Government or any agency thereof. 


\begin{abstract}
The cost-benefit outlook of black liquor gasification (BLG) could be greatly improved if the smelt causticization step could be achieved in situ during the gasification step. Or, at a minimum, the increase in causticizing load associated with BLG could be mitigated. A number of chemistries have been proven successful during black liquor combustion. In this project, three in situ causticizing processes (titanate, manganate, and borate) were evaluated under conditions suitable for high temperature entrained flow BLG, and low temperature steam reforming of black liquor. The evaluation included both thermodynamic modeling and lab experimentation. Titanate and manganate were tested for complete direct causticizing (to thus eliminate the lime cycle), and borates were evaluated for partial causticizing (to mitigate the load increase associated with BLG). Criteria included high carbonate conversion, corresponding hydroxide recovery upon hydrolysis, non process element (NPE) removal, and economics. Of the six cases (three chemistries at two BLG conditions), only two were found to be industrially viable: titanates for complete causticizing during high temperature BLG, and borates for partial causticizing during high temperature BLG. These two cases were evaluated for integration into a gasification-based recovery island. The Larsen [28] BLG cost-benefit study was used as a reference case for economic forecasting (i.e. a 1500 tpd pulp mill using BLG and upgrading the lime cycle). By comparison, using the titanate direct causticizing process yielded a net present value (NPV) of $\$ 25 \mathrm{M}$ over the NPV of BLG with conventional lime cycle. Using the existing lime cycle plus borate autocausticizing for extra capacity yielded a NPV of \$16M.
\end{abstract}




\section{CONTENTS}

$\begin{array}{ll}\text { Abstract } & 3 \\ \text { Introduction } & 4 \\ \quad \text { Scope of Work } & 7 \\ \text { Experimental } & 8 \\ \text { Results and Discussion: } & 14 \\ \quad \text { Equilibrium Modeling } & 14 \\ \quad \text { Experimental Results and Discussion } & 22 \\ \quad \text { Char Leaching } & 29 \\ \quad \text { XRD Analysis of Titanate Chars } & 32 \\ \quad \text { NPE Removal } & 34 \\ \quad \text { Mill Integration and Economics } & 38 \\ \text { Conclusions } & 46 \\ \text { Future Work } & 48 \\ \text { Acknowledgements } & 48 \\ \text { References } & 49 \\ \text { List of Abbreviations } & 51 \\ \text { Appendix A. Experimental Data } & 52 \\ \text { Appendix B. Jacobs Engineering Mill Integration and Economic Report } & 112\end{array}$

\section{INTRODUCTION}

In order for both the low and high temperature black liquor gasification (LTBLG, HTBLG) technologies to become economically viable alternatives to the conventional recovery cycle, the issues relating to causticization and dregs purge must be addressed. LTBLG (i.e. the MTCI process) is carried out with steam, in a fluidized bed, at $600^{\circ} \mathrm{C}$, near atmospheric pressure, and requires over 50 hours residence time for organic carbon conversion. $600^{\circ} \mathrm{C}$ is well below the melting point of the inorganic products, producing a solid inorganic phase which is then dissolved to make green liquor. HTBLG (i.e. the Chemrec process) is carried out with air or oxygen, using an entrained flow reactor, at approximately $950^{\circ} \mathrm{C}$, and requires about 5 seconds residence time. It can be accomplished at either atmospheric or pressurized conditions, and it produces a molten inorganic phase, which is then quenched into an aqueous solution. Causticization refers to the overall conversion of $\mathrm{Na}_{2} \mathrm{CO}_{3}$ to $\mathrm{NaOH}$ and $\mathrm{CO}_{2}$. In a conventional recovery boiler the reducing conditions in the char bed region produce partial causticization of the smelt prior to exiting the boiler. Additionally, a portion of the sodium in the smelt is bound up as $\mathrm{Na}_{2} \mathrm{~S}$, thereby reducing the amount of sodium available to form $\mathrm{Na}_{2} \mathrm{CO}_{3}$. Causticization of the remaining $\mathrm{Na}_{2} \mathrm{CO}_{3}$ is then completed by the lime cycle. In the case of LTBLG, the bulk of the sulfur ends up in the gas phase, and the solid product is predominantly $\mathrm{Na}_{2} \mathrm{CO}_{3}$, creating an even greater causticizing load than for conventional recovery. If scrubbing is used to remove $\mathrm{H}_{2} \mathrm{~S}$ from the gas, then some $\mathrm{CO}_{2}$ will be co- 
absorbed; this $\mathrm{CO}_{2}$ must also be causticized. The inherent separation of sulfur and sodium creates opportunities for high yield pulping but the additional causticizing load must be addressed. The situation is only slightly better for HTBLG. The sulfur is split between the gas and solid phases so a smaller portion of the sulfur is available to bind up sodium as $\mathrm{Na} 2 \mathrm{~S}$ as compared to conventional recovery. Additionally, in the Chemrec HTBLG system, the water quenching of the smelt results in co-absorption of $\mathrm{CO}_{2}$, which must be subsequently causticized. So, although the reasons are different for each case, increased causticizing load will be a problem for both HTBLG and LTBLG processes.

Direct and auto causticizing processes offer a solution to this problem. These in situ processes involve adding some chemical agent to either the black liquor or the product smelt that reacts preferentially with the sodium to form a salt and thus allow the carbon to be released as $\mathrm{CO}_{2}$. At the minimum, partial in situ causticization would mitigate the increase in causticizing load compared to conventional recovery; thus allowing existing lime cycle equipment to be used in conjunction with a gasifier. However if a sufficiently high yield of in situ causticization can be obtained, it would eliminate the need for the lime cycle resulting in significant energy and capital savings.

Currently there are three promising processes that are worthy of testing and evaluation, at realistic gasifier conditions, for feasibility of partial and complete in situ causticization during BLG. Methods of purging dregs will be explored for the feasible processes. Finally, economic and mill integration studies will be performed for the viable candidates. The three processes are:

\section{Direct Causticization using Titanates.}

In this system sodium trititanate is added to the liquor to bind up the sodium as pentatitanate and allow the carbon to be released as $\mathrm{CO}$ or $\mathrm{CO}_{2}$. The main reactions involved are considered to be:

$$
\begin{gathered}
\mathrm{Na}_{2} \mathrm{CO}_{3}+3 \mathrm{TiO}_{2}(\mathrm{~s}) \Leftrightarrow=\mathrm{Na}_{2} \mathrm{O} 3 \mathrm{TiO}_{2}(\mathrm{~s})+\mathrm{CO}_{2}(\mathrm{~g}) \\
7 \mathrm{Na}_{2} \mathrm{CO}_{3}+5\left(\mathrm{Na}_{2} \mathrm{O} 3 \mathrm{TiO}_{2}\right)(\mathrm{s})<=3\left(4 \mathrm{Na}_{2} \mathrm{O} 5 \mathrm{TiO}_{2}\right)(\mathrm{s})+7 \mathrm{CO}_{2}(\mathrm{~g}) \\
\mathrm{Na} 2 \mathrm{O} \cdot 6 \mathrm{TiO} 2(\mathrm{~s})+\mathrm{Na} 2 \mathrm{CO} 3(\mathrm{~s}) \leftrightarrow 2(\mathrm{Na} 2 \mathrm{O} \cdot 3 \mathrm{TiO} 2)(\mathrm{s})+\mathrm{CO} 2(\mathrm{~g})
\end{gathered}
$$

[Abbreviated NT3, N4T5, NT6]

Reaction (1) is how make-up titanate is introduced to the system. Reactions (2) and (3) are repeated cyclically in the gasifier. The sodium pentatitanate formed in the gasifier is leached with water, forming solid sodium trititanate and sodium hydroxide (white liquor) via reaction (4):

$$
\begin{gathered}
3\left(4 \mathrm{Na}_{2} \mathrm{O} 5 \mathrm{TiO}_{2}\right)(\mathrm{s})+7 \mathrm{H}_{2} \mathrm{O} \leftrightarrow 14 \mathrm{NaOH}(\mathrm{aq})+5\left(\mathrm{Na}_{2} \mathrm{O} 3 \mathrm{TiO}_{2}\right)(\mathrm{s}) \\
2(\mathrm{Na} 2 \mathrm{O} \cdot 3 \mathrm{TiO} 2)(\mathrm{s})+\mathrm{H} 2 \mathrm{O} \leftrightarrow 2 \mathrm{NaOH}(\mathrm{aq})+\mathrm{Na} 2 \mathrm{O} \cdot 6 \mathrm{TiO} 2(\mathrm{~s})
\end{gathered}
$$

Recent work at IPST has shown that NT3 can be further leached to NT6 via reaction (5), which has additional causticizing potential than NT3 via reaction (3). The leached NT3 and NT6 solids are separated from the caustic (white liquor) and recycled to the gasifier/reactor where reactions (2) and (3) repeat. For HTBLG the remaining solution is sulfur-lean white liquor since some $\mathrm{Na}_{2} \mathrm{~S}$ is present. For LTBLG the remaining solution is non-sulfur white liquor since virtually no $\mathrm{Na}_{2} \mathrm{~S}$ is present in the solid phase. The $\mathrm{H}_{2} \mathrm{~S}$ 
is separated from the gasification gas and can be used to produce an aqueous sulfur-rich stream. Consequently, white liquors of varying sulfidity can be obtained as shown in Figure 1 below.

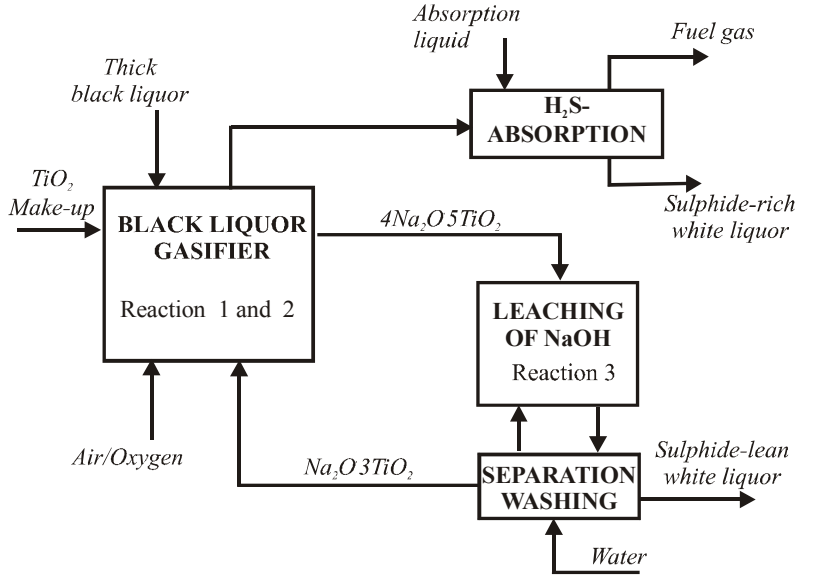

Figure 1. Black liquor gasification process with titanate direct causticization. The process would be analogous for manganates.

The kinetics of these reactions has been shown to be fast enough to occur within a HTBLG system [2\&3]. Nearly complete conversion was obtained at $900-1000^{\circ} \mathrm{C}$ under $\mathrm{CO}_{2}$ gasification conditions. It was also found that the causticization reactions took place faster during simultaneous black liquor gasification than for mixtures of titanate and carbonate with no black liquor. This is strong evidence that complete causticization could be obtained in a gasifier. The chemistry must be tested under pressurized, water vapor/O2 blown gasification conditions representative of those found in a Chemrec-type gasifier. Also, the means to purge dregs must be addressed.

A number of studies [11]-[15] have shown that titanates will causticize sodium carbonate under conditions relevant to LTBLG. However, minimal work has been done during actual BLG [15], and even that was done under gasification with $\mathrm{CO}_{2}$. To date, no published BLG work has been done with titanates in water vapor at or near $600^{\circ} \mathrm{C}$.

\section{Direct Causticization using Manganates.}

In this system $\mathrm{Mn}_{3} \mathrm{O}_{4}$ is added to bind up the sodium and allow carbon to be released as $\mathrm{CO}$ or $\mathrm{CO}_{2}$. For gasification, the process schematic would be analogous to that shown in Figure 1. A Canadian patent [29] describes a direct causticizing process using $\mathrm{MnO}_{2}$, but there was no experimental work supporting the claims. Eames and Empie [4\&5] have determined the causticization reaction to be:

$$
\mathrm{Na}_{2} \mathrm{CO}_{3}+\mathrm{Mn}_{3} \mathrm{O}_{4}=>2 \mathrm{NaMnO}_{2}+\mathrm{MnO}+\mathrm{CO}_{2}
$$

Over $98 \%$ conversion was obtained in under 24 hours for both the solid $\left(650-850^{\circ} \mathrm{C}\right)$, and liquid $\left(850-950^{\circ} \mathrm{C}\right)$ phase regimes chosen for this work. $\mathrm{Mn} 3 \mathrm{O} 4$ is recovered and hydroxide is formed upon hydrolysis:

$$
2 \mathrm{NaMnO}_{2}+\mathrm{MnO}+\mathrm{H}_{2} \mathrm{O}=>2 \mathrm{NaOH}(\mathrm{aq})+\mathrm{Mn}_{3} \mathrm{O}_{4}(\mathrm{~s})
$$

The $\mathrm{Mn}_{3} \mathrm{O}_{4}$ precipitate would then be separated from the solution and added to the black liquor entering the gasifier. A major consideration is whether manganate will interfere 
with sulfur chemistry. When $\mathrm{Na}_{2} \mathrm{~S}$ was added to reaction (6), it was oxidized to $\mathrm{Na}_{2} \mathrm{SO}_{4}$ as shown in reaction (8); however the metallic sulfide $(\mathrm{MnS})$ was not found in either the product smelt or the precipitate following hydrolysis [4\&5].

$$
\mathrm{Na}_{2} \mathrm{~S}+4 \mathrm{Mn}_{3} \mathrm{O}_{4}=>\mathrm{Na}_{2} \mathrm{SO}_{4}+12 \mathrm{MnO}
$$

So, in a system where significant amounts of sulfur partition into the smelt phase (HTBLG, and conventional recovery boilers), this creates a problem in that a major pulping chemical is oxidized and must then be reduced in a separate process. For this reason we feel it is fruitless to pursue this process under HTBLG conditions. However, in LTBLG virtually all of the sulfur leaves with the gas as H2S. It has yet to be determined experimentally if $\mathrm{H} 2 \mathrm{~S}$ released during $\mathrm{LTBLG}$ will react to form MnS. It has been determined [4] that the required residence time for causticization via reaction (6) is much less than the 50 hours of residence time required by the MTCI LTBLG process, and is therefore worthy of further investigation under LTBLG conditions.

\section{Autocausticization using Borates.}

In this process the sodium would be bound up by borate in the gasifier as follows:

$$
\mathrm{NaBO}_{2}+\mathrm{Na}_{2} \mathrm{CO}_{3}<=>\mathrm{Na}_{3} \mathrm{BO}_{3}+\mathrm{CO}_{2}
$$

The caustic is recovered upon hydrolysis:

$$
\mathrm{Na}_{3} \mathrm{BO}_{3}+\mathrm{H}_{2} \mathrm{O}=>2 \mathrm{NaOH}(\mathrm{aq})+\mathrm{NaBO}_{2}(\mathrm{aq})
$$

Note here that autocausticization differs from direct causticization in that the agent is soluble in water and thus circulates through the pulping cycle. The dregs would be the only precipitates, resulting in a convenient removal mechanism. The drawback is that the circulating borates are essentially dead load with respect to the pulping operation, somewhat limiting the throughput capacity. The use of borates for partial autocausticizing (as incremental capacity) in kraft mills is well documented, and mill trials have been successful [6]-[8]. Partial borate autocausticization has been obtained with black liquor under $\mathrm{CO}_{2}$ gasification conditions at 5 bar in the IPST pressurized gasifier (PEFR) at $950^{\circ} \mathrm{C}$ [9]. Additional testing is needed to determine if complete autocausticization can be obtained at HTBLG, and if the process is viable at LTBLG conditions.

\section{Scope of Work}

In Phase I of the project the in situ causticizing technologies will be tested, both experimentally and with an equilibrium model, at realistic black liquor gasification conditions to determine if complete causticization can be achieved, or alternately if sufficient partial (approximately 40\%) in situ causticization can be achieved. The high temperature borate and titanate cases will be evaluated using the pressurized entrained flow reactor at IPST. The low temperature experiments with borate, titanate, and manganate will be carried out at IPST using a semi-batch fixed bed reactor. A special autotitrator on loan from U.S. Borax will be used to analyze the borate samples. Standard analytical techniques will be used on the remaining samples. In all cases, the goal is to gasify the liquor/agent mixtures under conditions representative of the gas leaving an industrial gasifier. In Phase II the processes that pass Phase I will be developed for potential ways to purge dregs. The dregs will first be characterized. Possible purge 
methods include, but are not limited to: selective dissolution, clarifiers, liquid cyclones, and agglomerating agents. Passing Phase III requires that a sound method for dregs purge be developed. The options will be assessed jointly by all collaborators after the dregs have been characterized. IPST will then conduct laboratory measurements to test the proposed methods. In Phase III the processes that pass Phase II (if any) would undergo an economic evaluation including a plan for mill/gasifier integration. This will be done by James Cantrell of Jacobs Engineering Group with the support of all collaborators as needed.

\section{EXPERIMENTAL}

The in situ causticization reactions (Reactions 2, 6, and 9) were evaluated both experimentally and with an equilibrium computer model. The equilibrium calculations were carried out using FactSage ${ }^{\mathrm{TM}}$ 5.1, which determines the equilibrium composition of a chemical system by minimizing Gibbs free energy of the entire system. It was introduced in 2001 as a fusion of the FACT-Win ${ }^{\mathrm{TM}} / \mathrm{F}^{*} \mathrm{~A}^{*} \mathrm{C}^{*} \mathrm{~T}^{\mathrm{TM}}$ and ChemSage $^{\mathrm{TM}} / \mathrm{SOLGASMIX}{ }^{\mathrm{TM}}$ thermochemical packages. The FactSage ${ }^{\mathrm{TM}}$ package runs on a PC operating under Microsoft Windows and consists of a series of information, database, calculation, and manipulation modules.

The composition of the base liquor used in this project is shown in Table 1. It is fairly typical North American kraft liquor. Various causticizing agents were added in the proportions shown in Table 2. The combined elemental composition was used as input to FactSage $^{\mathrm{TM}}$, and for the experiments.

\begin{tabular}{|lc|}
\hline \multicolumn{2}{|c|}{$\begin{array}{c}\text { Table 1 } \\
\text { Starting Black Liquor Dry Mass }\end{array}$} \\
Carbon & Composition \\
Hydrogen & $34.8 \%$ \\
Oxygen & $3.1 \%$ \\
Sodium & $35.6 \%$ \\
Sulfur & $19.5 \%$ \\
Potassium & $5.2 \%$ \\
Chlorine & $1.7 \%$ \\
& $0.1 \%$ \\
\hline
\end{tabular}

\begin{tabular}{|c|c|c|c|}
\hline \multicolumn{4}{|c|}{ Table } \\
Causticizing Agent Additions to Black Liquor \\
\hline & Compound & $\mathrm{g} / \mathrm{Kg}$ DBLS & Metal/Na mass ratio \\
\hline Titanate (100\% conv) & $\mathrm{Na}_{2} \mathrm{O} \cdot 3 \mathrm{TiO}_{2}$ & 960 & 1.34 \\
\hline Borate (20\% conversion) & $\mathrm{NaBO}^{*} * 2 \mathrm{H} 2 \mathrm{O}$ & 58 & 0.03 \\
\hline Manganate (100\% conv) & $\mathrm{Mn} 3 \mathrm{O} 4$ & 979 & 3.62 \\
\hline
\end{tabular}




\begin{tabular}{|c|c|}
\hline & $\begin{array}{l}\text { Table } 3 \\
\text { Species Included in the FactSage Equilibrium Calculations }\end{array}$ \\
\hline Gases & $\begin{array}{l}\mathrm{CH}_{4}, \mathrm{C}_{2} \mathrm{H}_{2}, \mathrm{C}_{2} \mathrm{H}_{4}, \mathrm{C}_{2} \mathrm{H}_{6}, \mathrm{CO}, \mathrm{CO}_{2}, \mathrm{COS}, \mathrm{CS}, \mathrm{CS}_{2}, \mathrm{H}, \mathrm{HS}, \mathrm{H}_{2} \mathrm{~S}_{2}, \mathrm{H}_{2}, \mathrm{H}_{2} \mathrm{O}, \\
\mathrm{H}_{2} \mathrm{~S}, \mathrm{O}, \mathrm{O}_{2}, \mathrm{OH}, \mathrm{N}, \mathrm{N}_{2}, \mathrm{~S}, \mathrm{~S}_{2}, \mathrm{SO}, \mathrm{SO}_{2}, \mathrm{SO}_{3}, \mathrm{SSO}, \mathrm{Na}, \mathrm{Na}_{2}, \mathrm{NaOH}, \mathrm{NaCN}\end{array}$ \\
\hline Liquids* & 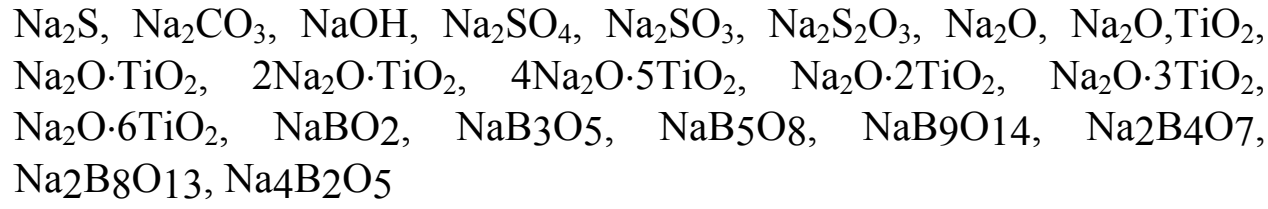 \\
\hline \multirow[t]{2}{*}{ Solids* } & 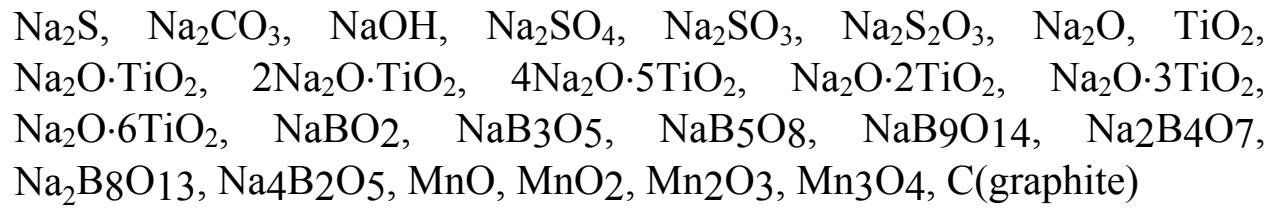 \\
\hline & $\begin{array}{l}\text { * Two key compounds, } \mathrm{Na}_{3} \mathrm{BO}_{3} \text { and } \mathrm{NaMnO}_{2} \text {, were not found in the } \\
\text { FactSage database. Data could not be found in the literature for these } \\
\text { compounds. See text for explanation. }\end{array}$ \\
\hline
\end{tabular}

Table 3 shows the relevant chemical species included in the modeling. For species not included in the FactSage thermodynamic database, the required information can be added, assuming it is available. One key borate compound is not included in the database and data for that compound could not be found in the literature. However, some conclusions can still be drawn for the borate system and the rationale for doing so is explained in the results section. For the manganate system, the database did not include any sodium-manganese compound, nor could the required data be found in the literature. The manganate system therefore could not be modeled.

The experimental portion of the work was performed in specialized reactors that mimic the conditions of temperature, pressure, and gas composition found in full scale gasifiers. They are described in detail below. The black liquor fuels were prepared by doping the liquor shown in Table 1 with causticizing agents as shown in Table 2, drying in a laboratory oven at $110 \mathrm{C}$, grinding in a ball mill, and finally sieving to obtain particles of size 63-90 microns.

\section{Laminar Entrained Flow Reactors}

Laminar entrained-flow reactors have been used extensively to investigate coal, biomass, and black liquor combustion and gasification. The advantages of using a laminar entrained-flow reactor for gasification studies are the rapid heating and cooling rates which allow for experiments at nearly isothermal conditions for controlled amounts of time, and the possibility to make experiments in controlled and well-defined gas atmospheres. The atmospheric-pressure entrained-flow reactor (LEFR) located at IPST 
(schematic shown in Figure 2) has been successfully utilized for numerous studies of black liquor pyrolysis, combustion and gasification. A larger pressurized entrained flow reactor (PEFR) has been used successfully in three studies involving various aspects of gasification of black liquor $[9,18,19]$.

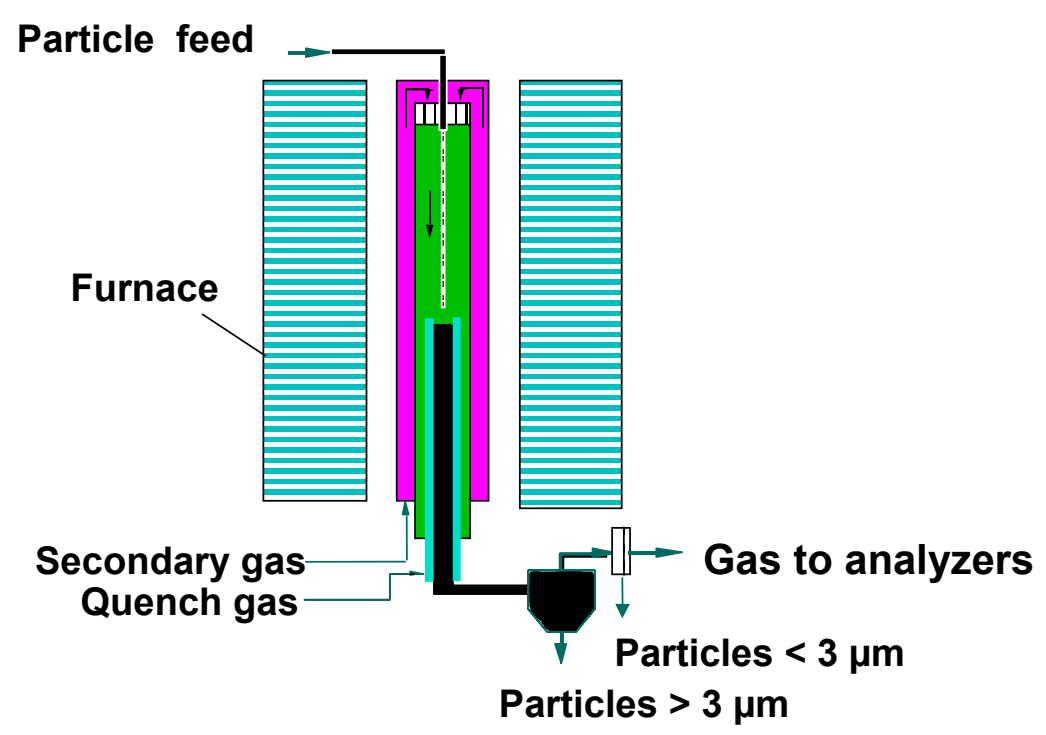

Figure 2. Diagram of an entrained flow reactor

In these reactors, solid particles of the material to be gasified are entrained in the primary gas stream and fed into the reactor via a water-cooled injection tube. A secondary gas stream, which constitutes the main part of the reaction gas is preheated to the desired reaction temperature and then enters the reactor concentric to the particles and primary gas stream. The solid particles and the primary gas are rapidly heated (particle heating rates of $10^{4}-10^{5}{ }^{\circ} \mathrm{C} / \mathrm{s}$ ) by radiation from the hot reactor walls and convection from the hot secondary gas. The flow pattern through the reactor is laminar to prevent deposition of particles on the reactor walls. The gas and particles exit via a water-cooled probe. They are rapidly cooled by a quench gas that is introduced at the upper tip of the collector. The particles are separated from the sample gas and collected, and the gas is sent to gas analyzers. Placing such a reactor inside a pressure vessel allows for variable pressure. Photos of the PEFR and LEFR are shown in Figure 3. 

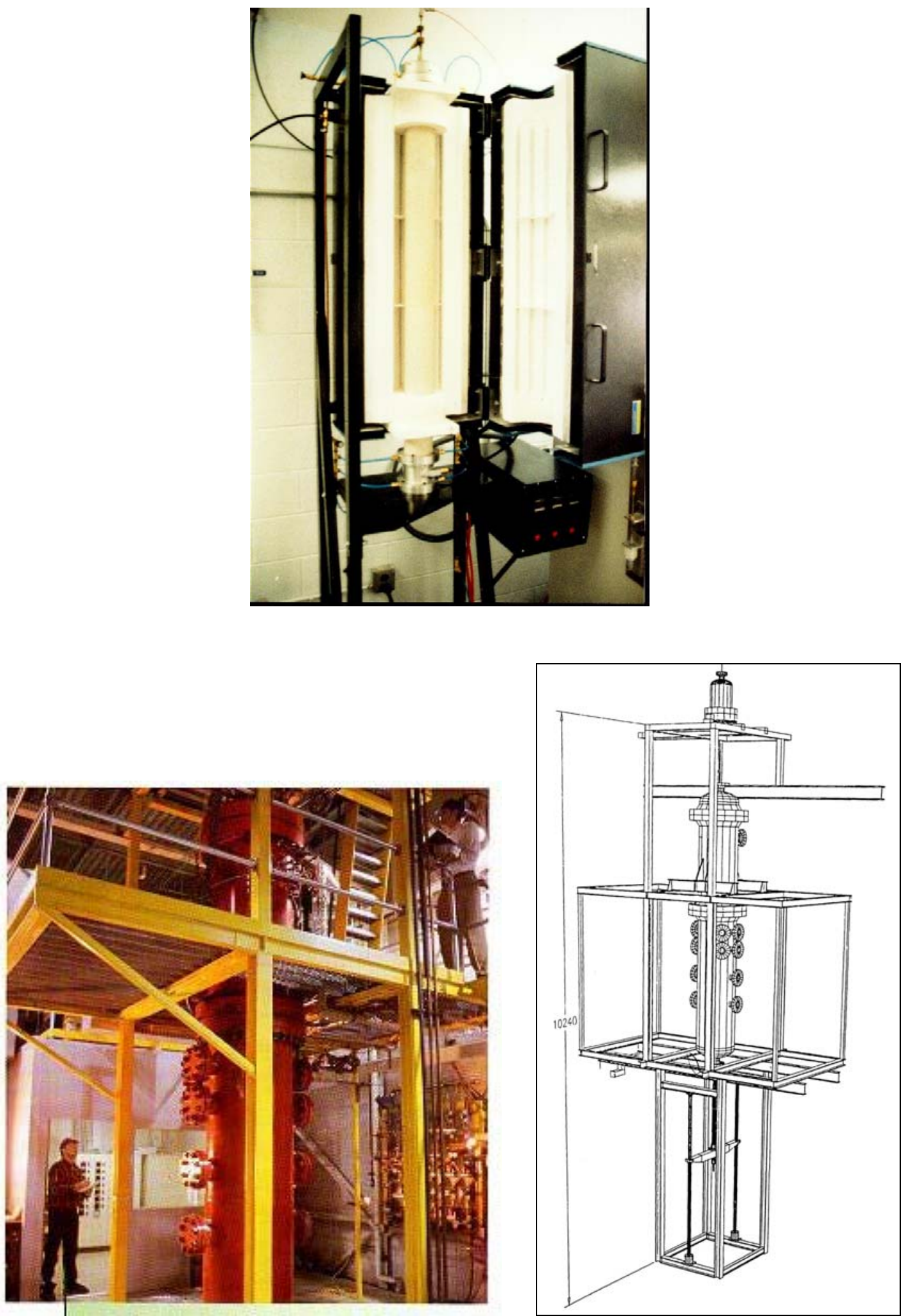

Figure 3. IPST's LEFR (top) shown with furnace open. Total height is 11 feet. Lower left is IPST's PEFR. Lower right is a CAD drawing of the PEFR. Total height is 35 feet. 
An LEFR also has the flexibility of functioning as a semi-batch reactor. Rather than feeding fuel continuously, a sample container (supported by the collector probe) is placed inside the reactor. The reactor is purged with an inert gas and heated to the test temperature. The reaction gases are then fed through the reactor for a fixed amount of time, and then the reactor is cooled down and the sample removed. The heating and cooling time should be small compared to the total exposure time for good results. For the LTBLG experiments described above, the total residence time (50 hours) is large compared to the heat-up time ( 1 hour). The feed gas composition can be chosen to approximate the product gas composition from an industrial gasifier. In this way, a batch of solid fuel is exposed to the same conditions as if it was in a flow reactor or fluidized bed. A fixed bed reactor can be used to obtain gas-solid reaction conversion data, which can then be corrected to fluid bed conditions [20]. In this way, the difficulties of operating a lab-scale black liquor fluid bed reactor are avoided (i.e. agglomeration, carryover, temperature variations, etc).

The experimental conditions are summarized in Table 4. The causticizing agents were added to black liquor in the ratios shown in Table 2, mixed, and then spray-dried. The mixture ratios (doping levels) reflect amount calculated from the stoichiometry above to achieve specified conversions shown in the table. The solids were sieved to 63-90 microns for use in the entrained flow reactors.

\begin{tabular}{|l|c|c|c|}
\hline \multicolumn{4}{|c|}{ Table 4. Experimental conditions } \\
\hline Leactor & LEFR (semi-batch) & $\begin{array}{c}\text { Pressurized High } \\
\text { Temp }\end{array}$ & $\begin{array}{c}\text { High Temp at 1 bar } \\
\text { (for borates only) }\end{array}$ \\
\hline Temperature C & 600 & 950 & LEFR (flow) \\
\hline Pressure, bar & 1 & $5 \& 15$ & 950 \\
\hline Feed gas & $\begin{array}{c}50 \% \mathrm{H} 2 \mathrm{O} \text { in N2, } \\
\text { with and w/o 5\% } \\
\text { and } 10 \% \mathrm{CO} 2\end{array}$ & $\begin{array}{c}5 \% \text { N2, with and w/o } \\
3 \% \mathrm{H} 2 \mathrm{O}\end{array}$ & $\begin{array}{c}2 \% \text { \& } 5 \% \mathrm{CO} 2 \text { in } \\
\text { N2 }\end{array}$ \\
\hline Residence time & 50 hours & 5 seconds & 2 seconds \\
\hline
\end{tabular}

After reacting the doped liquors in the respective reactors, the residual solid material (char) was collected and analyzed by Coulometry for total carbon and carbonate carbon, and by Inductively Coupled Plasma emission spectroscopy for $\mathrm{Na}, \mathrm{K}, \mathrm{Mn}, \mathrm{Ti}$, and $\mathrm{B}$. These tests each required about 1 gram of sample. If a sufficient mass of char was recovered on the borate experiments (additional 2 grams per test), then it was dissolved in water and titrated using a special dual titration technique. In this technique, developed by U.S. Borax, the sample is split into two parts to be titrated simultaneously by hydrochloric acid, and by silver nitrate. The combined results of the two titrations yields the concentration of carbonate, bicarbonate, hydroxide, borate, and sulfide ions. The test assumes that no other titratable ions are present in solution. 


\section{Char Leaching Procedure}

For the titanate and manganate cases, the char must be leached in accordance with reactions (3) and (9) to obtain aqueous hydroxide and the insoluble starting agent (which would be recycled to the gasifier with fresh black liquor in the real world process). The leachate (solution) can then be titrated for determination of carbonate and hydroxide concentrations.

The analytical leaching of the char samples was carried out in a $500 \mathrm{ml}$ 3-necked flask (Figure 4) equipped with a water-cooled condenser, a thermometer and a Pasteur pipette through which $\mathrm{N}_{2}$ gas was bubbling through in order to eliminate air $\left(\mathrm{O}_{2}\right.$ and $\left.\mathrm{CO}_{2}\right)$. While provided constant stirring with magnetic stirrers, the flask was heated via an oil bath in order to bring the water to boil. Evaporated water was condensed on the condenser and fell back down into the flask. When the distilled and deionized water reached its boiling point, $1.000 \mathrm{~g}$ of the recycled sample was added to the boiling water. The leaching time was 90 minutes in order to ensure complete reaction. Some of the samples were leached multiple times as explained in later sections.

After the leaching time had elapsed, the flask with the contents was removed from the oil bath and allowed to cool to room temperature. When cooled, the solution was quantitatively transferred to a previously weighed $60 \mathrm{ml} 4-5.5 \mu \mathrm{m}$ fine glass filter Büchner funnel set up on a 1-liter Erlenmeyer flask and suction filtered by using an aspirator. The filtrate was thereafter transferred to a $250 \mathrm{ml}$ volumetric flask and diluted with distilled and deionized water and put aside for further analysis. The filter cake was dried in an oven overnight $\left(105^{\circ} \mathrm{C}\right)$, and then weighed and stored for further analysis. Finally, the filtrate's caustic concentration was determined by acidimetric titration in a 751 GPD Titrino from Metrohm.

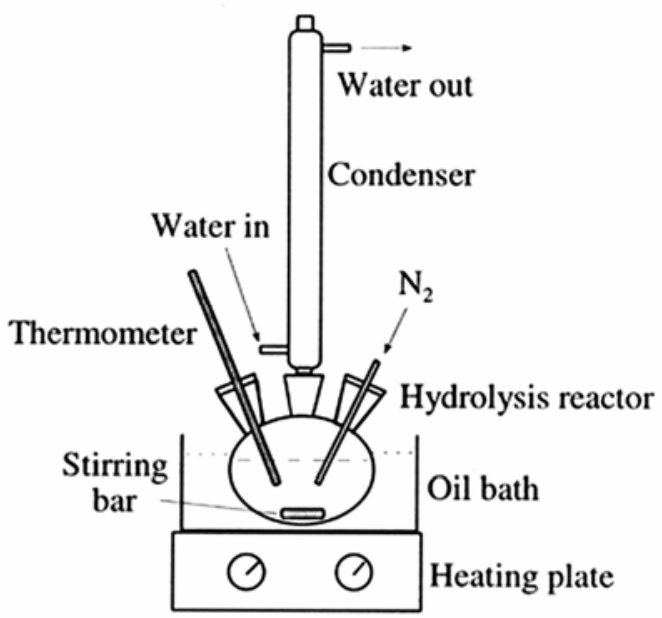

Figure 4. The leaching apparatus.

A $25 \mathrm{ml}$ sample volume of the $\mathrm{Na}-\mathrm{Ti}$ leachate was pipetted into a beaker. Barium chloride, $10 \mathrm{wt} \%$, was added to the sample to bind any anions, such as carbonate, that would interfere with the titration of $\mathrm{OH}^{-}$. After adding phenolphthalein (PP) indicator, the 
mixture was titrated to the PP end point 8.67 with a $0.1 \mathrm{M} \mathrm{HCl}$ solution. The volume of added $\mathrm{HCl}$ was noted and the $\mathrm{NaOH}$ concentration was calculated (see Appendix $\mathrm{B}$ ).

To account for sulfide a formaldehyde solution ( $\mathrm{HCHO}, 40 \%$ in water) was added to convert $\mathrm{Na}_{2} \mathrm{~S}$ to $\mathrm{NaOH}$. If there were any sulfide ions present, the pink color should return. If the pink color of PP returned, the mixture was titrated again to the PP end point.

\section{Other Analysis}

The titanate and manganate chars were also examined by X-ray diffraction (XRD), which can distinguish [qualitatively] between the reacted (e.g. N4T5) and unreacted (e.g. NT3) forms.

For the Phase II work on dregs purge, the leached solids were characterized by scanning electron microscopy (SEM) to determine how the non-process elements (NPE's or "dregs") were distributed; as discrete particles or bound to the titanate or manganate solids. This information was used to narrow the options for separating the NPE's from the leached solids prior to mixing the solids with fresh black liquor.

For the phase III work, the Larson study [28] was used as reference case for the economics of straight BLG. The incremental NPV and IRR of adding each in situ causticization case was then evaluated. For the mill integration study, the experimental results were used to build a WinGems ${ }^{\mathrm{TM}}$ model of a gasification based recovery island with in situ Causticization using the processes found viable in Phases I and II.

\section{RESULTS and DISCUSSION}

\section{Equilibrium Modeling Results}

\section{Borate Modeling}

For the equilibrium modeling the FactSage database contains data for several $\mathrm{Na} / \mathrm{B}$ compounds ( $\mathrm{NaBO}_{2}, \mathrm{NaB}_{3} \mathrm{O} 5, \mathrm{NaB} 5 \mathrm{O} 8, \mathrm{NaB} 9 \mathrm{O}_{14}, \mathrm{Na} 2 \mathrm{~B} 4 \mathrm{O}_{7}, \mathrm{Na} 2 \mathrm{~B} 8 \mathrm{O} 13, \mathrm{Na} 4 \mathrm{~B}_{2} \mathrm{O}_{5}$ ), but not Na3BO3. No thermodynamic data could be found in the literature. Only the existence of $\mathrm{Na}_{3} \mathrm{BO} 3$ is mentioned in a 1939 patent. This does not however completely prevent us from making some reasonable predictions about sodium borates and BLG. Consider the phase diagram in Figure 5 for oxides of sodium and boron. For the case of Reaction 1 (above), the reactant is $\mathrm{Na}_{2} \mathrm{O}_{-} \mathrm{B}_{2} \mathrm{O}_{3}$ and the desired product is $3 \mathrm{Na}_{2} \mathrm{O}-\mathrm{B}_{2} \mathrm{O}_{3}$. On a phase diagram, starting with $\mathrm{Na}_{2} \mathrm{O}-\mathrm{B}_{2} \mathrm{O}_{3}$ and increasing the ratio of $\mathrm{Na} / \mathrm{B}$, the species $3 \mathrm{Na}_{2} \mathrm{O}-\mathrm{B}_{2} \mathrm{O}_{3}$ (equivalent to $\mathrm{Na}_{4} \mathrm{~B}_{2} \mathrm{O} 5$ ) would be formed. Adding $\mathrm{Na}$ would eventually give $3 \mathrm{Na} 2 \mathrm{O}-\mathrm{B}_{2} \mathrm{O}_{3}$ (equivalent to $\mathrm{Na}_{3} \mathrm{BO}_{3}$ ). When viewed in this manor it is easy to see that if the thermodynamics do not favor the formation of $\mathrm{Na}_{4} \mathrm{~B}_{2} \mathrm{O}_{5}$, then it is unlikely that $\mathrm{Na} 3 \mathrm{BO} 3$ would be favored either. Therefore the FactSage prediction that no $\mathrm{Na}_{4} \mathrm{~B}_{2} \mathrm{O}_{5}$ forms during the gasification reaction also indicates that $\mathrm{Na}_{3} \mathrm{BO}_{3}$ should not form either. However that is not to say that if $\mathrm{Na}_{4} \mathrm{~B}_{2} \mathrm{O}_{5}$ does form then $\mathrm{Na}_{3} \mathrm{BO}_{3}$ would also. 


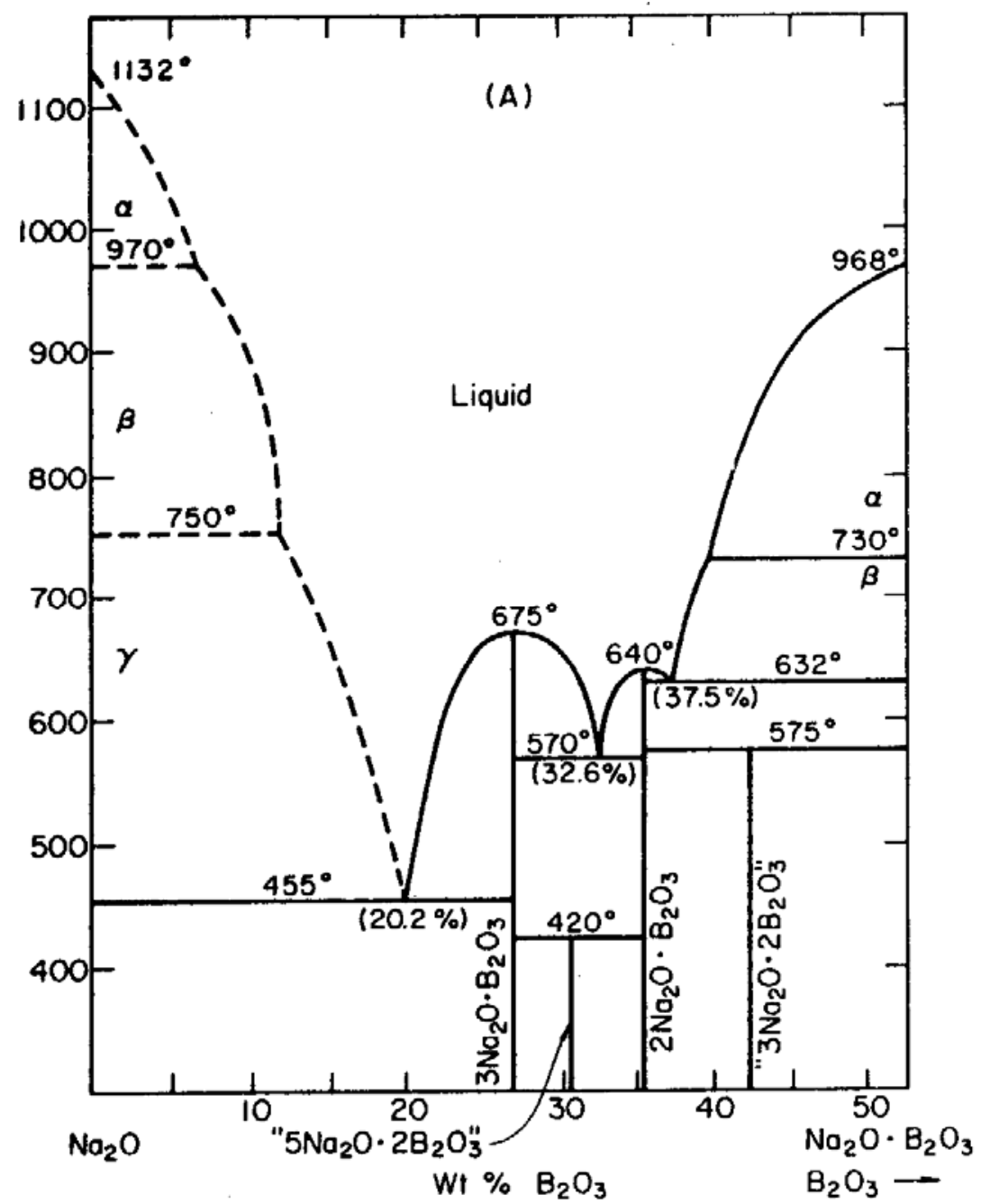

Figure 5. System Na2O-B2O3. Dashed lines refer to metastable equilibrium [21]. 
Figure 6 shows the FactSage equilibrium results for causticization of sodium carbonate in air as a function of temperature. In this simulation a large amount of air was used; therefore the hindering effects of $\mathrm{CO}_{2}$ were not modeled. The reaction is favored above 800C. This is consistent with the experimental results of Tran, et.al. [6]

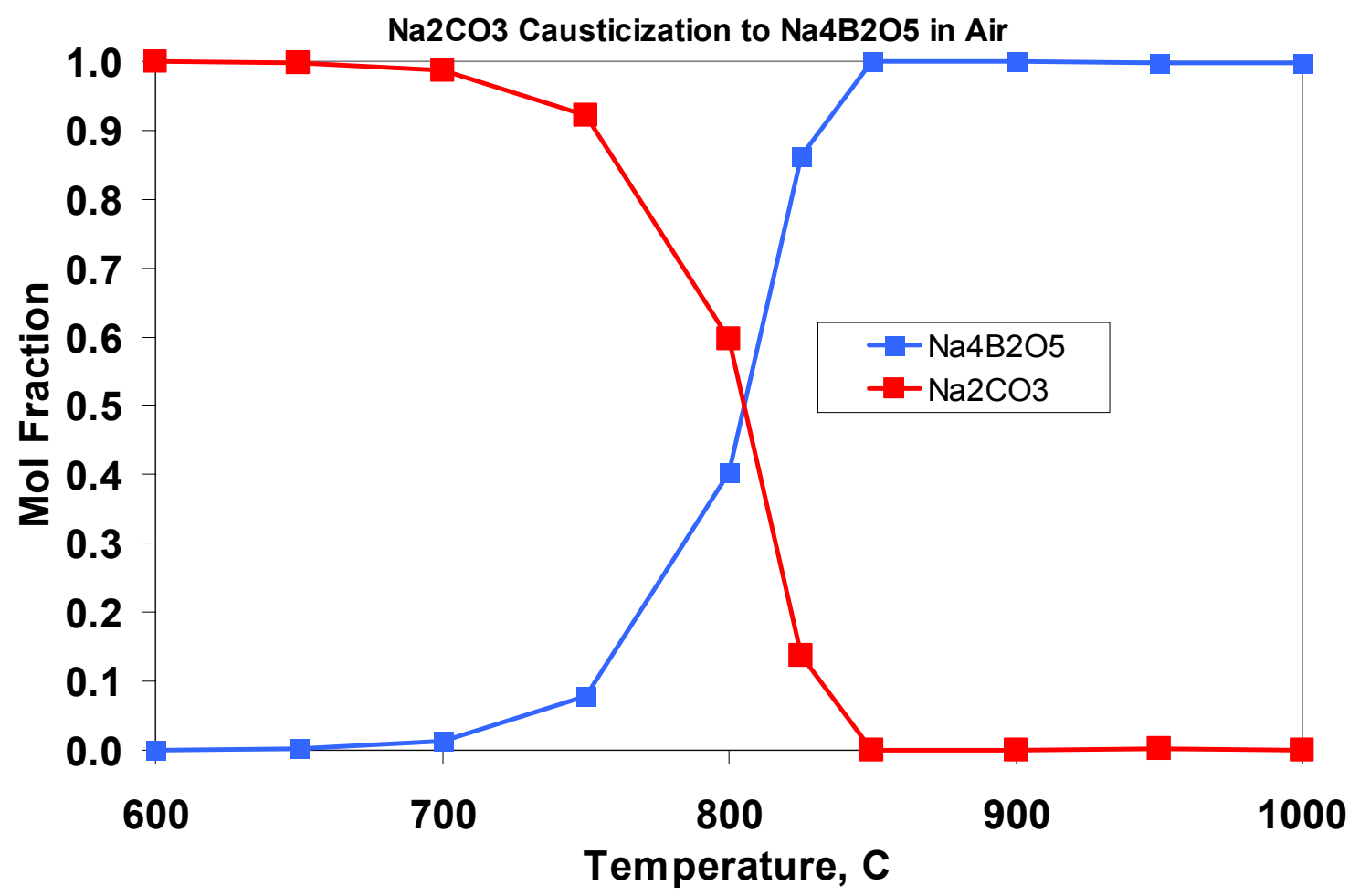

Figure 6. FactSage equilibrium model of sodium carbonate, sodium borate, at $100 \mathrm{mols}$ air per mol solid (i.e. excess air to dilute $\mathrm{CO}_{2}$ ). 
Figure 7 shows the FactSage prediction of the products of borate autocaust during $\mathrm{O}_{2}$ blown BLG. The $\mathrm{O}_{2} /$ fuel ratio is reasonable for industrial conditions. The autocaust (blue diamonds indicating $\mathrm{Na}_{4} \mathrm{~B}_{2} \mathrm{O}_{5}$ ) reaction is favored only at very low pressures; in this simulation below about 1.2 bar. Above 1.2 bar the reaction does not proceed due to the partial pressure of $\mathrm{CO}_{2}$ in the product gas. $\mathrm{CO}_{2}$ hinders reaction (9). This is not encouraging for potential $\mathrm{O}_{2}$-blown BLG envisioned to operate at 20-30 bar.

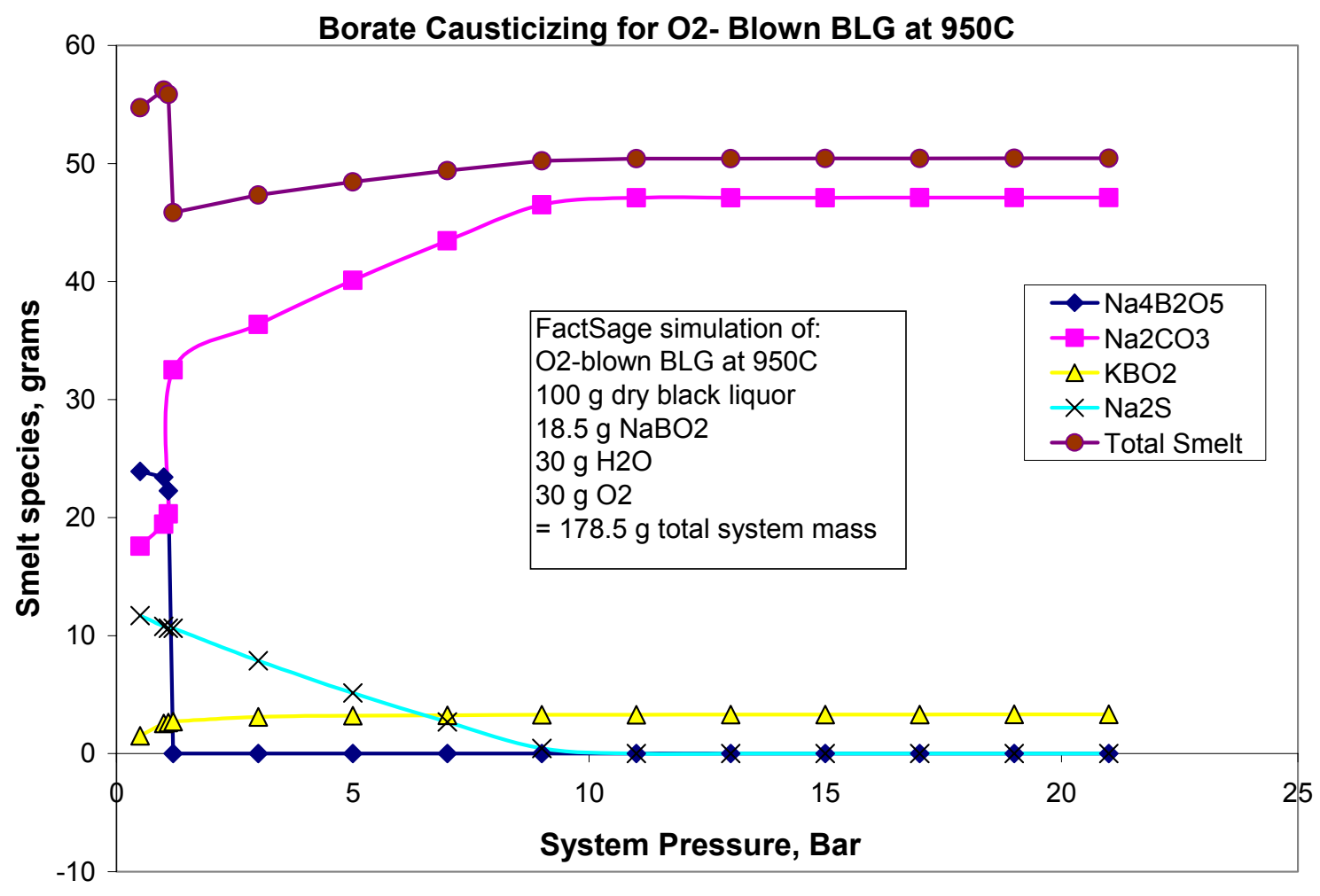

Figure 7. FactSage model of $\mathrm{O}_{2}-$ blown $\mathrm{BLG}$ at an industrial gas/solid ratio 
The impact of temperature on borate autocaust is shown in Figure 8 for the air-blown case BLG case. The result is dramatic. At $900 \mathrm{C}$ there is no conversion of $\mathrm{NaBO}_{2}$ to $\mathrm{Na}_{4} \mathrm{~B}_{2} \mathrm{O}_{5}$. Between $950 \mathrm{C}$ and $975 \mathrm{C}$ the reaction kicks in and carbonate is causticized. Note that the $\mathrm{NaBO}_{2}$ concentration drop s zero but there is still carbonate present. The doping level modeled is appropriate for complete conversion to $\mathrm{Na}_{3} \mathrm{BO}_{3}$. Since $\mathrm{Na}_{3} \mathrm{BO}_{3}$ is not in the FactSage database, the reaction can only proceed part way to $\mathrm{Na}_{2} \mathrm{~B}_{2} \mathrm{O}_{5}$. Thus some carbonate remains. While this is not proof that $\mathrm{Na}_{3} \mathrm{BO}_{3}$ would form, it is encouraging evidence. However the temperature of $950-975 \mathrm{C}$ for conversion is just about the value we expect to run.

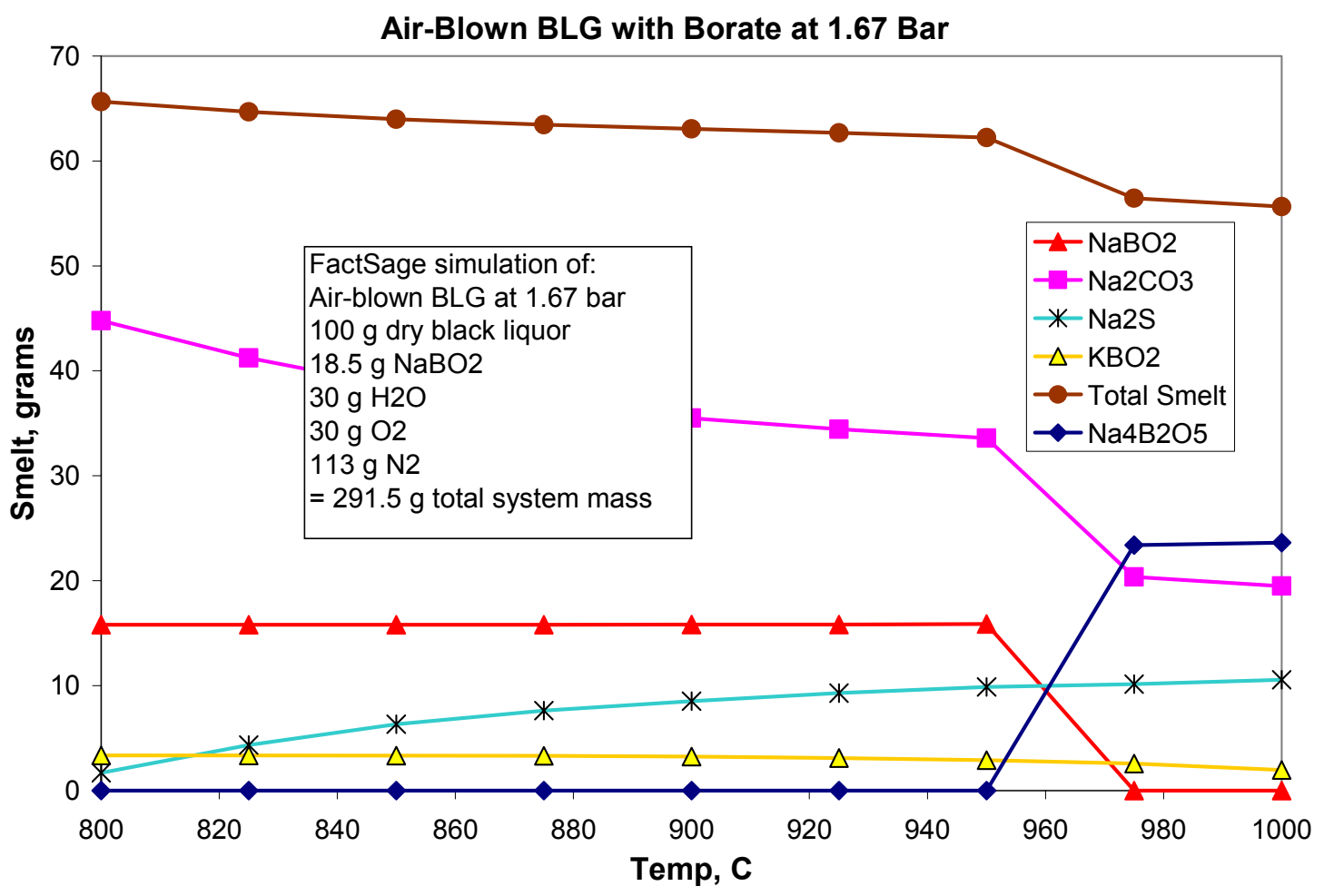

Figure 8. FactSage model of Air-blown BLG with borate at reasonable conditions for an industrial booster gasifier. 
Figure 9 shows the FactSage predictions for borate autocaust during steam reforming at 600C. The results are similar to the air-blown case. The reaction (i.e. Rxn 9) begins to take place above 950C. However steam reforming of black liquor is carried out at $600 \mathrm{C}$. In order for the bubbling bed steam reformer to work, the temperature must be kept below the melting point (in fact below the sticky temperature) of the solids. Therefore the FactSage model does not predict borate autocaust to work for black liquor steam reforming.

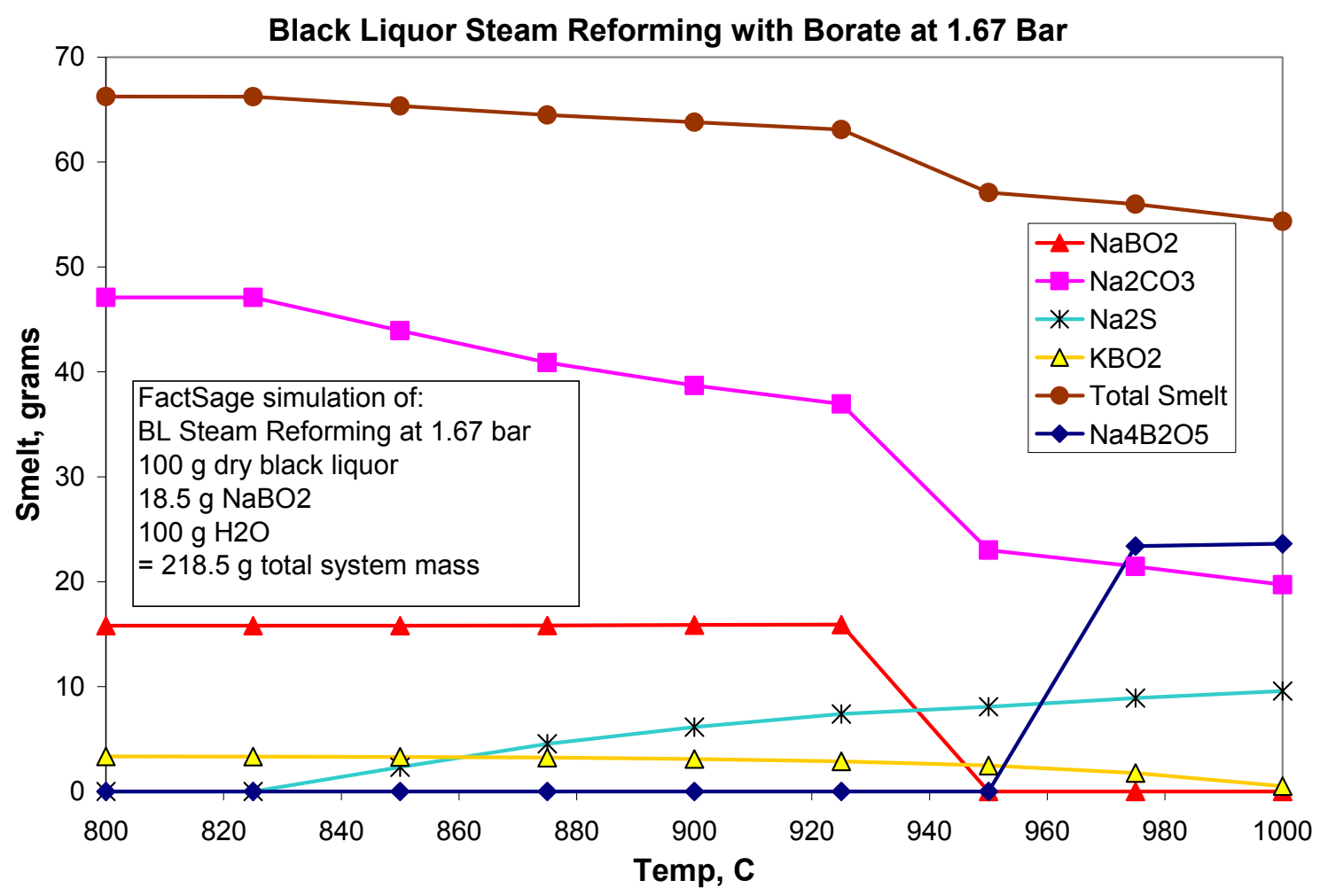

Figure 9. FactSage model of BLG with borate using steam over a range of temperatures. 


\section{Equilibrium Modeling of BLG and Titanates}

The FactSage simulation of BLG with titanate at air-blown atmospheric pressure conditions is shown in Table 10. The model predicts that causticizing conversion will take place above 600-650C. The conversion remains nearly complete until $800 \mathrm{C}$, where the last remaining NT3 forms N4T5. It is interesting to note the presence of the NT species at $600 \mathrm{C}$, so some causticizing is taking place even at 600C. Based on these results we would expect complete causticizing for BLG above 800C.

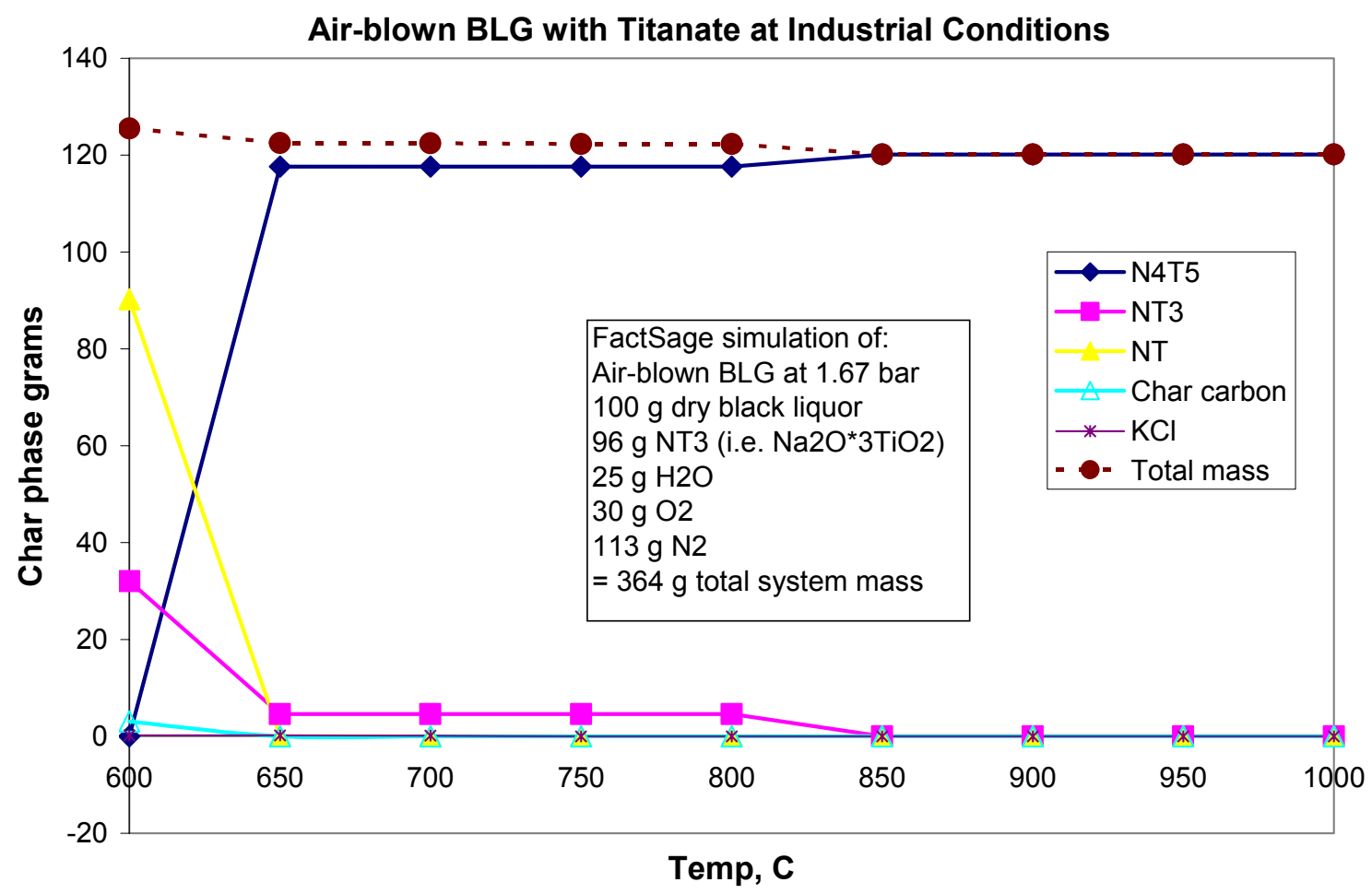

Figure 10. FactSage simulation of temperature dependence on air-blown BLG at 1.67 bar (10 psig) with titanate added for complete causticization. 
In Figure 11, we see the results of the pressure dependence on oxygen-blown BLG with titanate at 950C, which is the specified temperature for the HTBLG process. Causticizing is complete at pressures to 10 bar and only drops off a bit between 10 and 20 bar. Based on this simulation, we would expect titanates to work fine for both atmospheric and pressurized HTBLG.

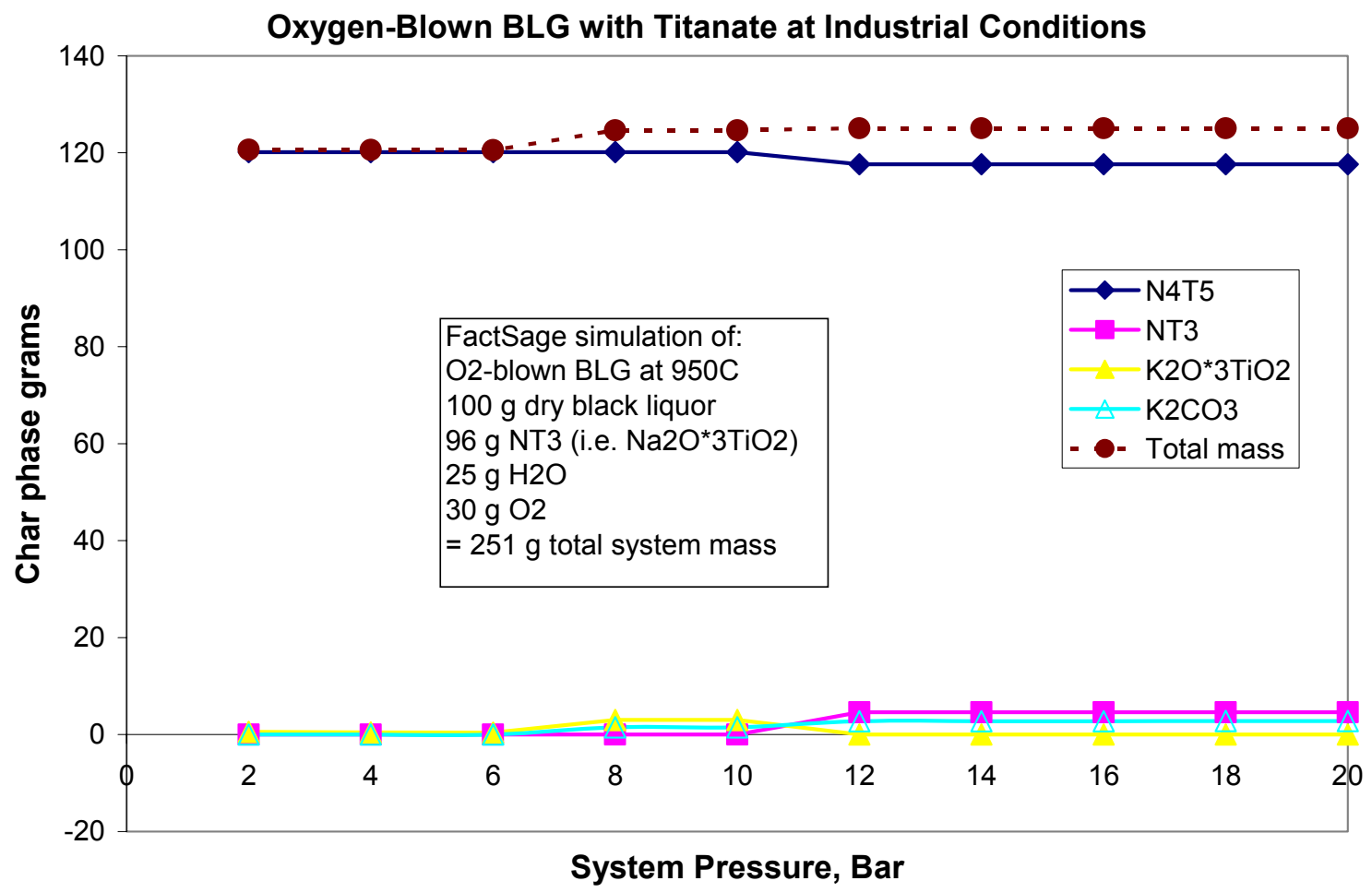

Figure 11. FactSage simulation of pressure dependence on oxygen-blown BLG at 950C with titanate added for complete causticization. 
In Figure 12 on the following page the FactSage simulation for BL steam reforming with titanate causticizing is shown. The specified temperature for the industrial-scale process is $600 \mathrm{C}$. The model predicts that the causticizing reactions progress at between 625 and $650 \mathrm{C}$. Therefore we would not expect titanates to work for the BL steam reforming process.

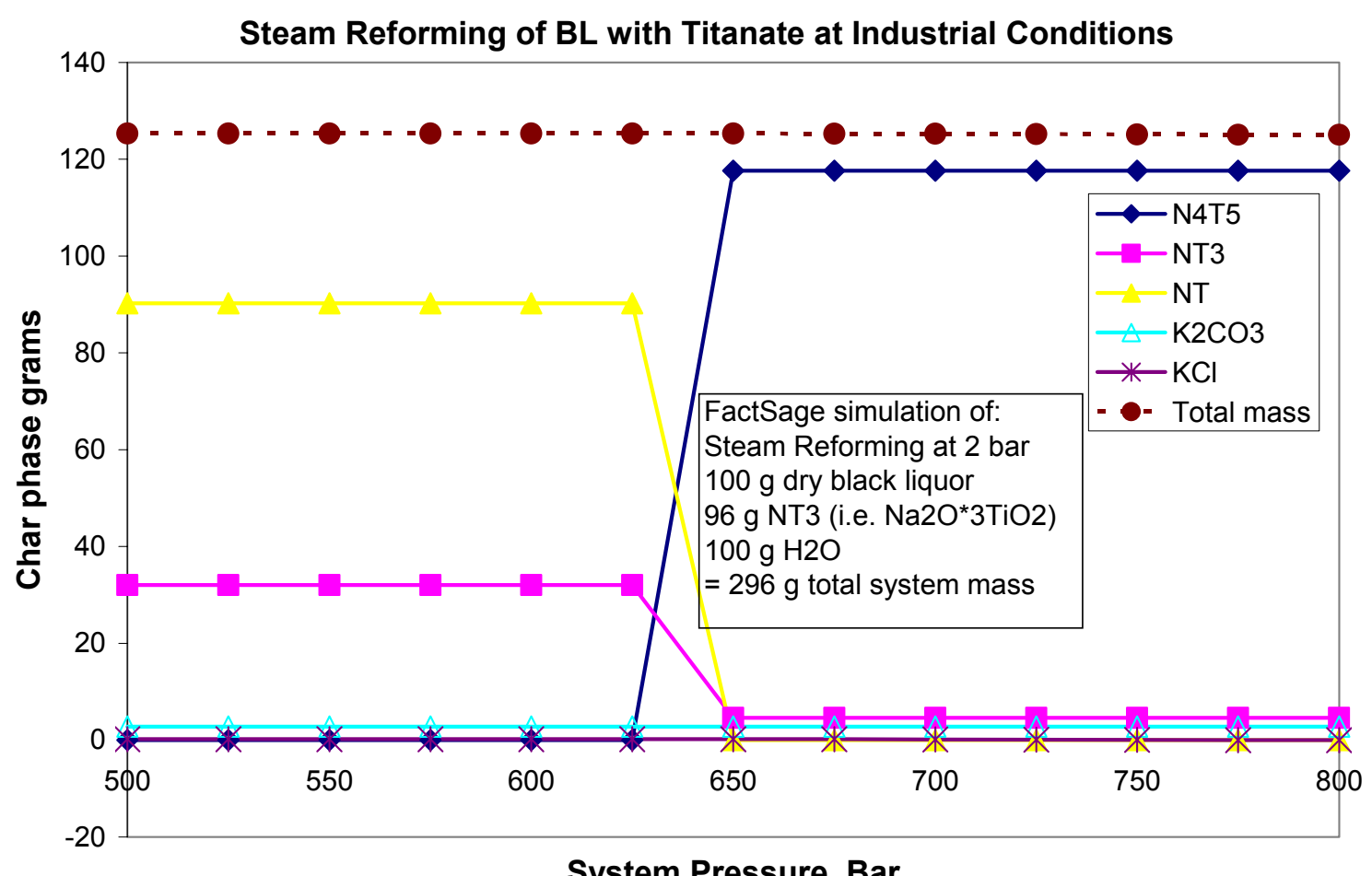

Figure 12. FactSage simulation of temperature dependence on steam reforming of BL at 2 bar, with titanate added for complete causticization.

\section{Equilibrium Modeling of BLG and Manganates}

It was not possible to model the manganate/BLG system since thermodynamic data for one key compound $\left(\mathrm{NaMnO}_{2}\right)$ was not in the FactSage database nor could it be found in the literature. Experimentation will have to suffice.

\section{Experimental Results and Discussion}

A Table of raw data from the experiments is included in Appendix 1. Some discussion of how the data were analyzed is in order. The objective of this work is to reduce the amount of carbonate in gasification smelt via Reactions (2), (6), and (9). However, even if the reactions do not take place (i.e. conversion $=0$ ) there will be a significant reduction in smelt carbonate due to the diluting effect of the causticizing agent. This must be 
accounted for in the interpretation of the data. This is done by applying some assumptions and simple stoichiometry to the liquor composition shown in Table 1 . The assumptions are as follows for the un-doped liquor:

1. Sodium forms chloride, sulfide, and carbonate

2. Potassium forms carbonate

3. The sulfur partitioned to the char phase in the high temperature case was measured for each experiment and the conversion back calculated based on the carbonate measured in the char. For the LT case, $100 \%$ of the sulfur portioned to the gas phase.

4. Complete gasification of fixed carbon is assumed

From these assumptions the composition of the smelt resulting from gasification of the black liquor is easily calculated. The result is the theoretical reference smelt and is shown in Table 5. The mass fraction of carbonate is the key quantity.

\begin{tabular}{|c|c|c|}
\hline \multicolumn{3}{|c|}{ Table 5 } \\
Theoretical Reference Smelt Composition \\
\hline Species & $\begin{array}{c}\text { HT case (example 60\% of S } \\
\text { to smelt) Mass \% }\end{array}$ & $\begin{array}{c}\text { LT case (no S in smelt) } \\
\text { Mass \% }\end{array}$ \\
\hline $\mathrm{Na}$ & $43.1 \%$ & $40.7 \%$ \\
\hline $\mathrm{K}$ & $3.8 \%$ & $3.5 \%$ \\
\hline $\mathrm{CO}_{3}$ & $46 \%$ & $55.6 \%$ \\
\hline $\mathrm{S}$ & $6.9 \%$ & - \\
\hline $\mathrm{Cl}$ & $0.2 \%$ & $0.2 \%$ \\
\hline
\end{tabular}

Once the reference smelt composition has been calculated, the causticizing agents are then included in the composition. Using stoichiometry again, the smelt composition is then calculated as a function of the conversion of the causticizing reactions. Specifically the theoretical carbonate concentration is calculated as a function of reaction conversion. This is done for each of the agents at each doping level. This is combined with the carbonate concentration in the reference smelt to obtain the percentage decrease in carbonate as a function of reaction conversion (shown in Figure 13). These relationships can be used to estimate the reaction conversion given the measured carbonate content in the smelt from the experiments. For example, $0 \%$ conversion would lead to a reduction in carbonate from the reference smelt due to dilution only. $50 \%$ conversion would yield a greater reduction in carbonate compared to the reference smelt (i.e. due to dilution and the causticizing reaction). By comparing experimental results from the doped liquors to experimental results from the un-doped liquor the net effect of the doping agent is measured. Then, the sulfur split must be taken into account as $\mathrm{Na} 2 \mathrm{~S}$ will offset $\mathrm{Na} 2 \mathrm{CO} 3$ formation sans any causticizing taking place. This is most accurately done by measuring the sulfur in the smelt (char) phase and adjusting the reference smelt to match. Table 5 assumes a sulfur split of $60 \%$ but it will likely vary for each experiment. This technique 
results in lines like those in Figure 13 for each data point. This is the method that was used to back calculate causticizing conversion from smelt carbonate data.

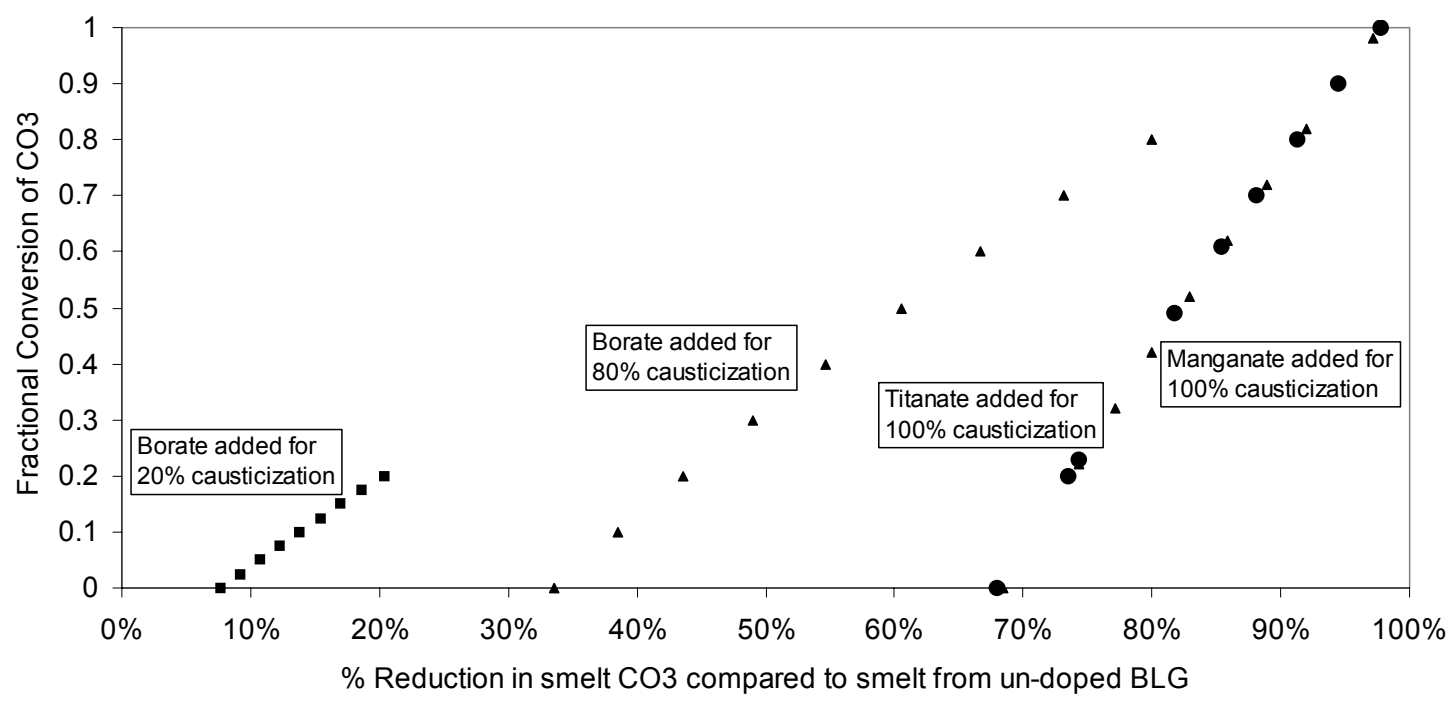

Figure 13. Predicted causticization reaction conversion as a function of the percent decrease in carbonate concentration compared to the reference (un-doped) case. These relationships are used to account for the diluting effects of the causticizing agent and translate the experimental smelt carbonate concentrations into the degree of reaction conversion.

\section{Titanate Experimental Results}

The results for the titanates at high temperature are shown in Figure 14. As expected from the stoichiometry and L'Chatlier's principal, $\mathrm{CO} 2$ inhibits all of the desired reactions. In order to utilize the results, we estimate the $\mathrm{CO} 2$ concentration in the syngas leaving a full scale gasifier over a range of conditions (Figure 15). These results are then superimposed on the experimentally derived conversion levels to estimate if the process in question would work in the real gasifier. The ranges of $\mathrm{CO} 2$ concentration are shown in Figure 14 to estimate the conditions for which titanates would be effective at high temperature. We estimate that from 1 to 5 bars total reactor pressure, the $\mathrm{CO} 2$ levels during BLG would be low enough to allow titanate direct causticizing (Task 1.1.2) to work to high conversion levels. This would correspond to a low pressure air or O2blown booster gasifier such at the one at Weyerhaeuser, New Bern. However, at 20 bars the conversion drops to zero. In order to be effective at 20 bars the process would have to be modified to lower the $\mathrm{CO} 2$ partial pressure in the product gas. 


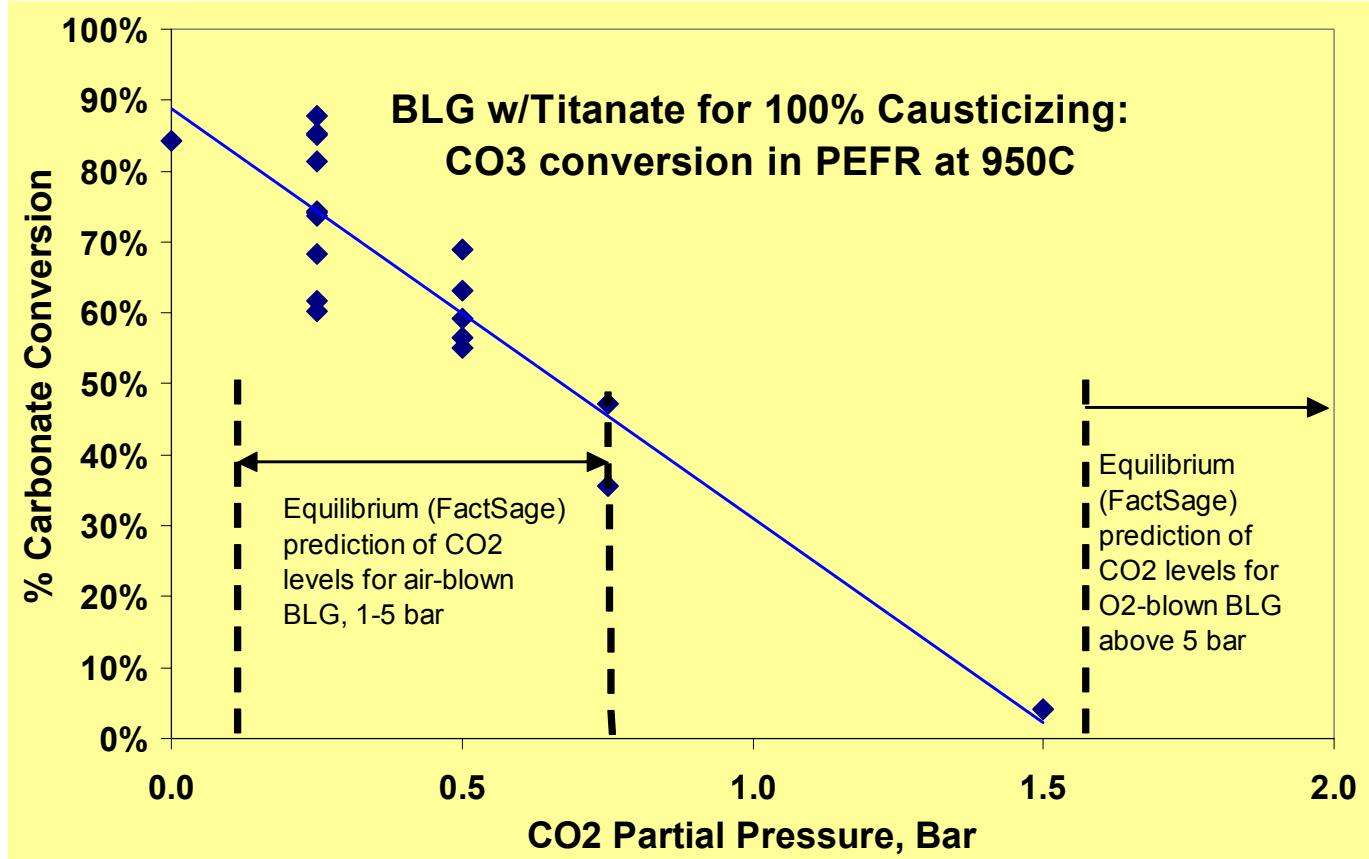

Figure 14. Titanate direct causticizing conversion at high temperature entrained flow as a function of $\mathrm{CO} 2$ partial pressure.

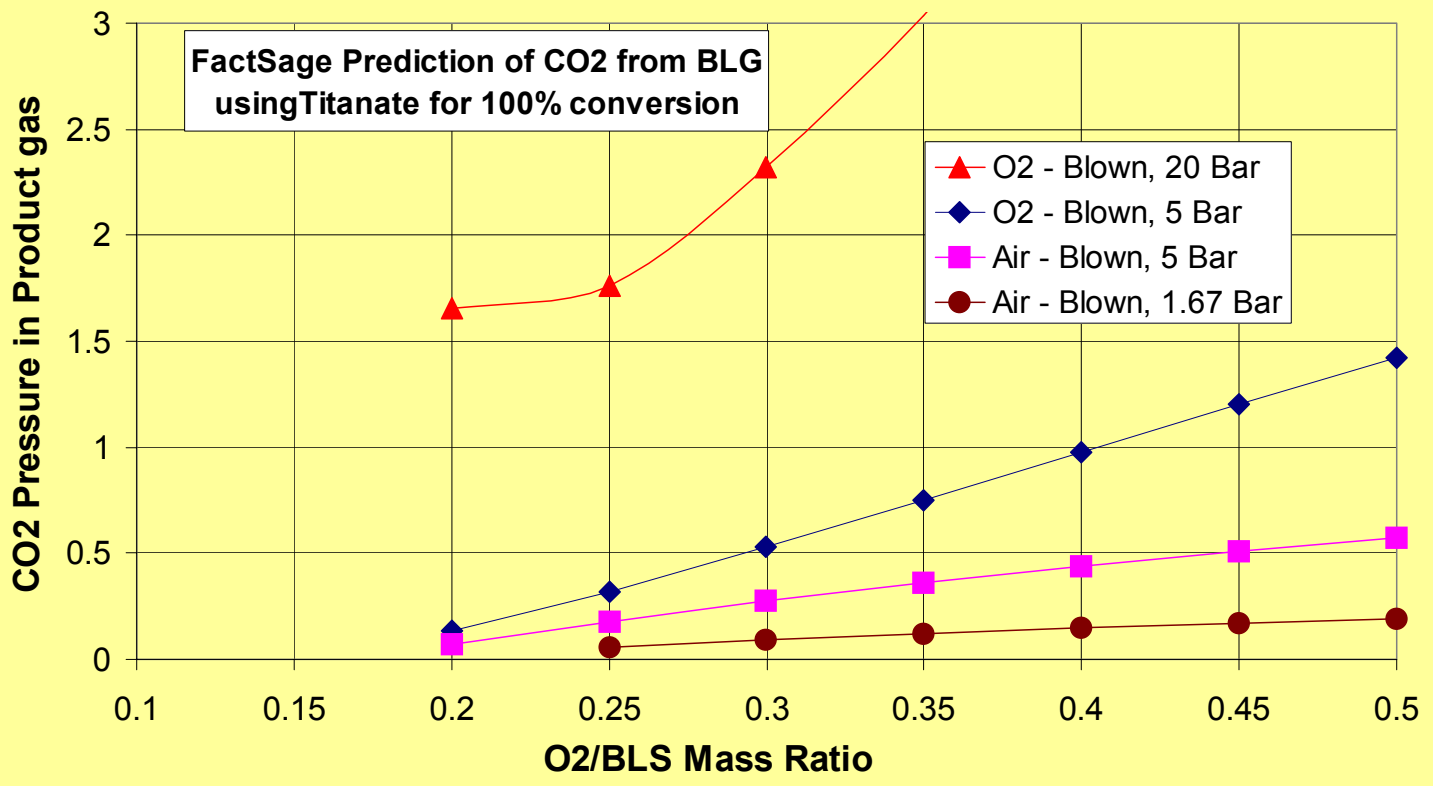

Figure 15. Equilibrium calculations of $\mathrm{CO} 2$ levels from black liquor gasification over a range of oxygen to fuel ratios. Realistic values are around 0.3 
The results for titanate direct causticizing during steam reforming (task 1.1.3) are shown in Figure 16. With no $\mathrm{CO} 2$ present, high conversions were achieved. However when $10 \% \mathrm{CO} 2$ was added, the conversion dropped to zero. Thus the titanate chemistry will not work for steam reforming in its current configuration. FactSage modeling suggests however that at $650 \mathrm{C}$ the reaction would reach high conversion. Given that titanates would also raise the smelting temperature of the char, the steam reformer temperature might well be raised to $650 \mathrm{C}$ without problems with bed sintering. For the present, no further work will be done with titanates for steam reforming.

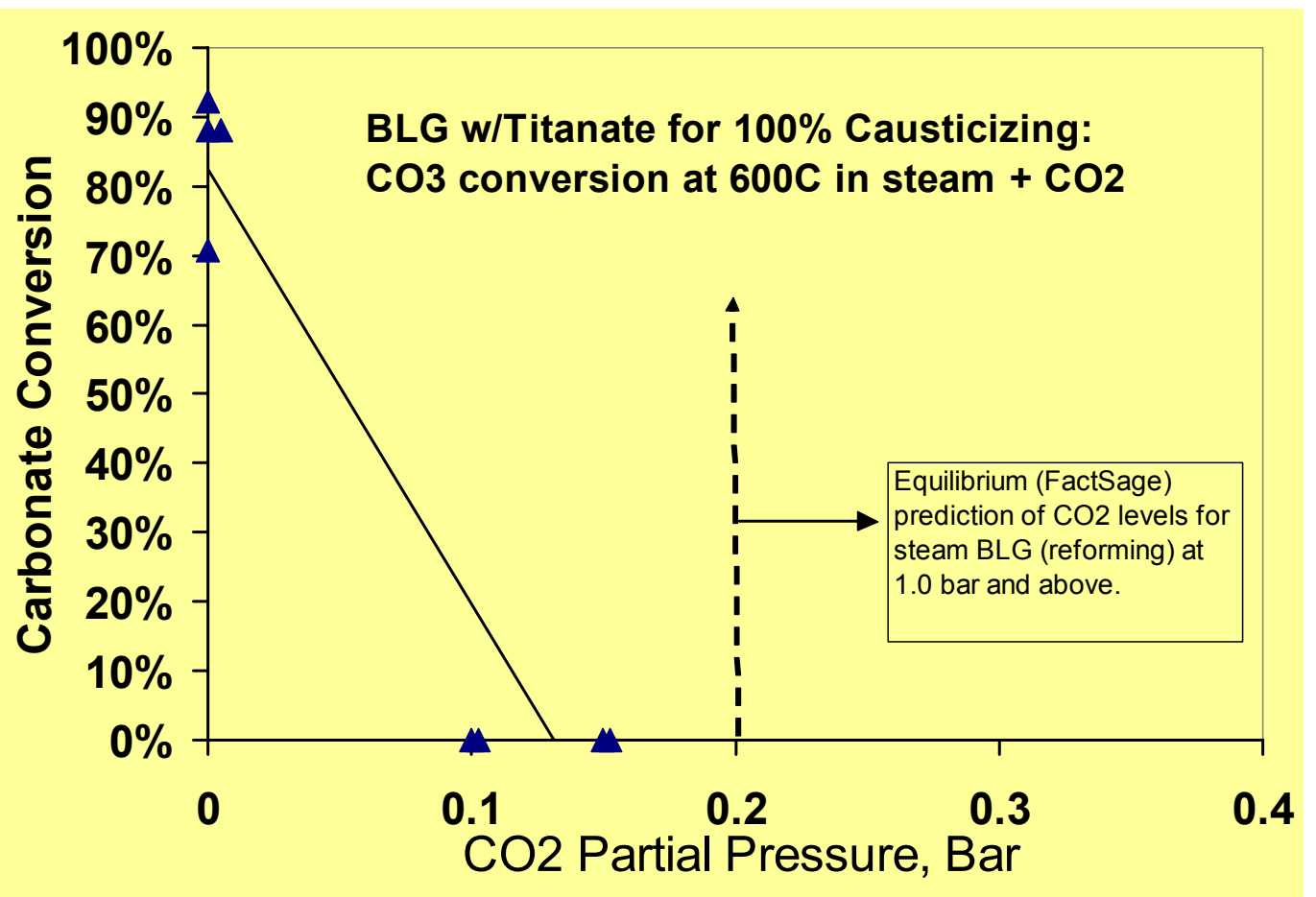

Figure 16. Titanate direct causticizing during steam reforming at 1 bar.

\section{Borate Experimental Results}

The experimental results for the borates (task 1.3.1) are shown in Figures 17 and 18 for partial $(20 \%)$ conversion. This would be appropriate for either a booster or full scale gasifier when the existing lime kiln will be used to handle the bulk of the causticizing load. At high temperature and low pressures, the chemistry reaches high conversion due to low $\mathrm{CO} 2$ partial pressure. The borates will be tested for complete causticization at $950 \mathrm{C}$ and low pressure as well. However, as before, at 20 bars total pressure, the CO2 would be sufficiently high to inhibit the conversion of this reaction as well. 


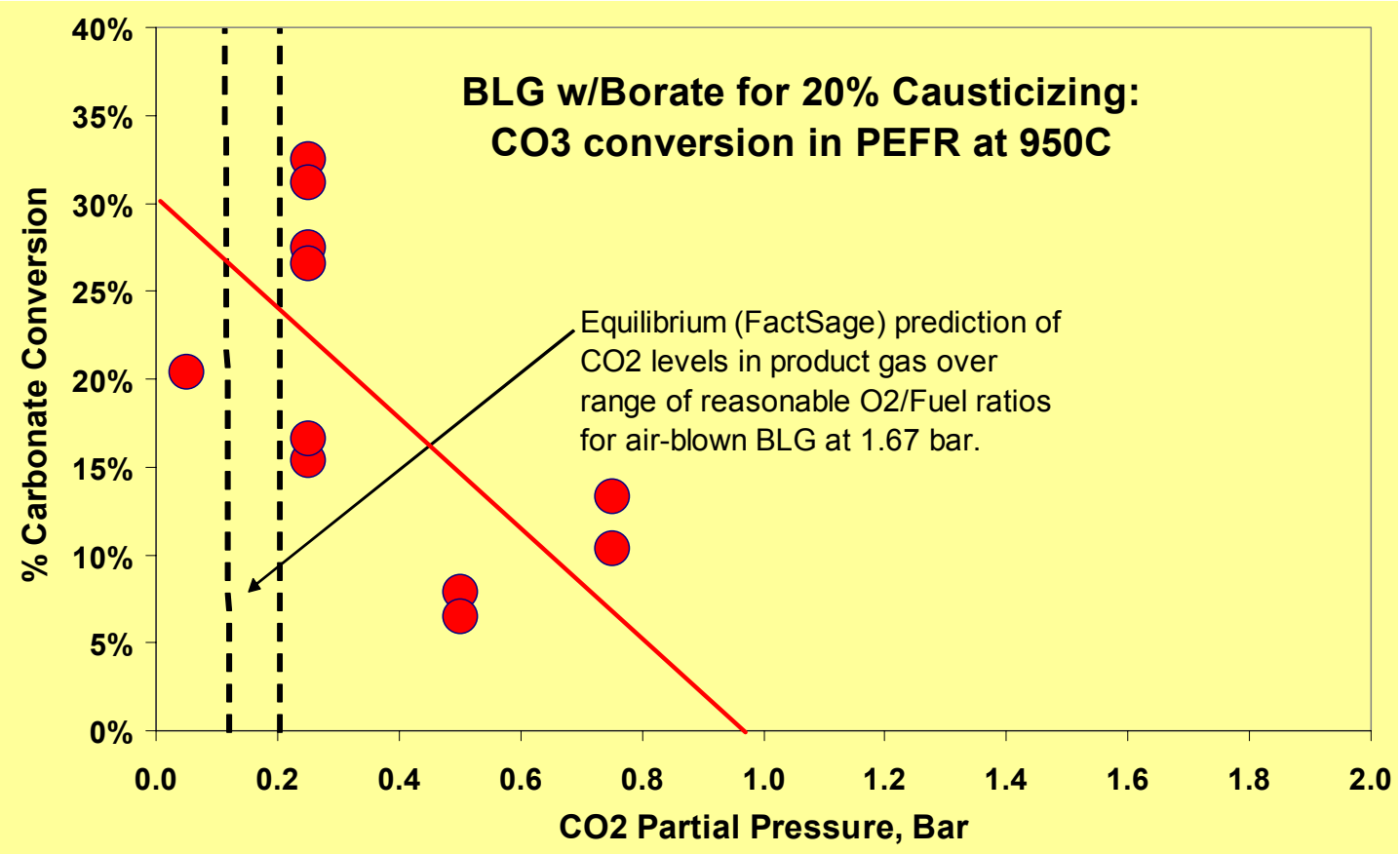

Figure 17. Borate autocausticization at high temperature

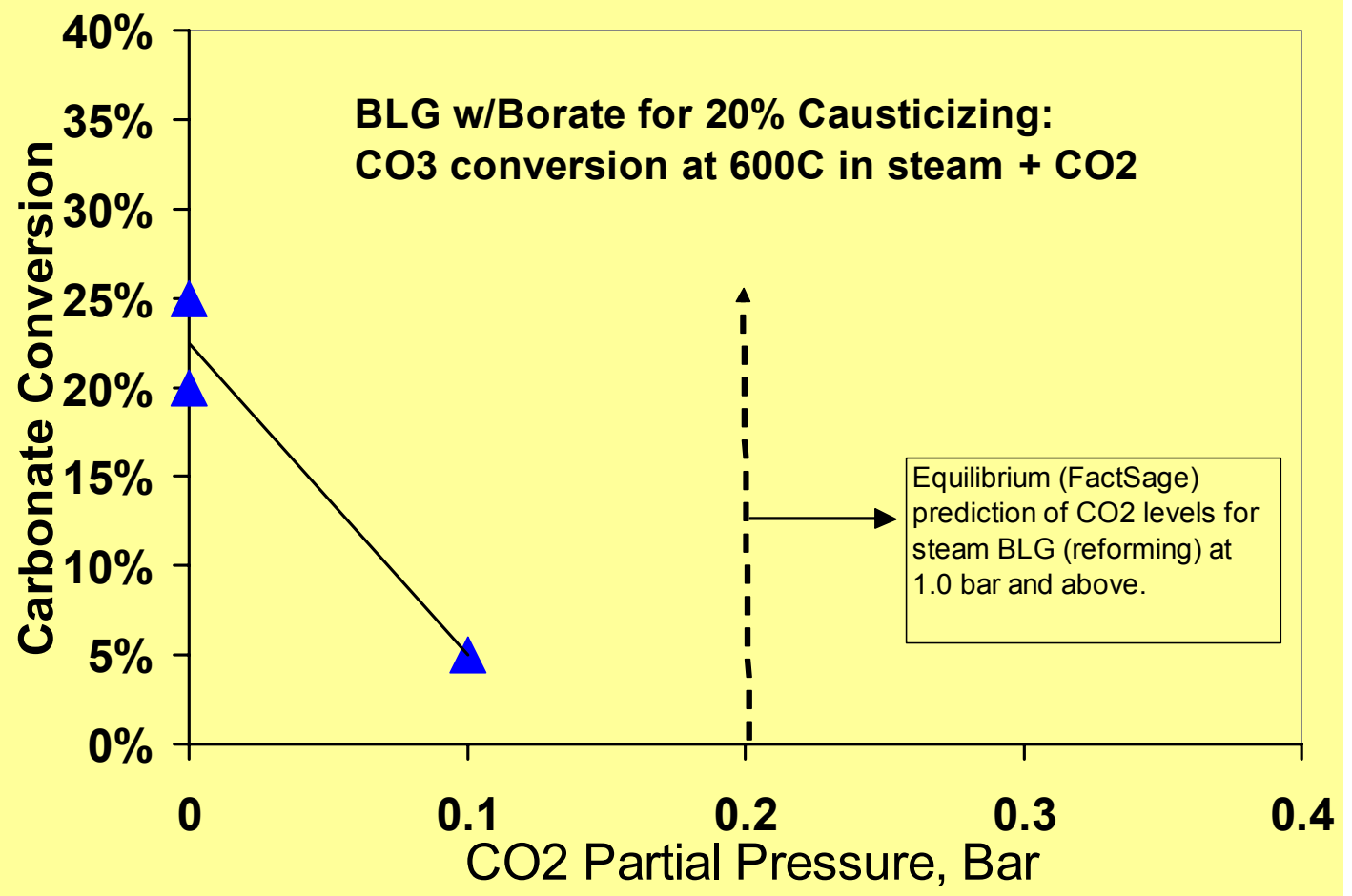

Figure 18. Borate autocausticization during steam reforming 
The steam reforming case for the borates at $20 \%$ conversion is shown in Figure 18. Again, the $\mathrm{CO} 2$ levels would be too high in the real gasifier to achieve any conversion. FactSage modeling suggests that the temperature would have to reach $925 \mathrm{C}$ before the causticizing reactions move forward in this case. Borates for steam reforming will not be considered further.

\section{Manganate Experimental Results}

The experimental results for gasification of manganate-doped black liquor are shown in Tables 6 and 7 (a graph is not in order for this case). For the high temperature case, zero conversion was achieved. Manganates for high temperature gasification will not be considered further.

\begin{tabular}{|c|c|c|c|}
\hline \multicolumn{4}{|c|}{ Table 6. Manganate conversion during high } \\
temperature gasification \\
$\begin{array}{c}\text { Gas } \\
\text { Conditions }\end{array}$ & $\begin{array}{c}\text { Stoichiometric } \\
\text { maximum } \\
\text { conversion } \\
\text { based on Mn } \\
\text { added }\end{array}$ & $\begin{array}{c}\text { Fixed } \\
\text { (i.e. char) } \\
\text { carbon in } \\
\text { smelt }\end{array}$ & $\begin{array}{c}\text { Experimental } \\
\text { causticizing } \\
\text { conversion }\end{array}$ \\
\hline $5 \% \mathrm{CO} 2$ & $100 \%$ & $0.6 \%$ & $\mathbf{0 \%}$ \\
\hline $5 \% \mathrm{CO} 2$ & $100 \%$ & $0.1 \%$ & $\mathbf{0 \%}$ \\
\hline $10 \% \mathrm{CO} 2$ & $100 \%$ & $0.5 \%$ & $\mathbf{0 \%}$ \\
\hline $10 \% \mathrm{CO} 2$ & $100 \%$ & $1.7 \%$ & $\mathbf{0 \%}$ \\
\hline
\end{tabular}

For the steam reforming case (Task 1.2.2), manganates gave complete conversion in almost all cases, with and without $\mathrm{CO} 2$ present. Experiments with manganates will continue into the non-process element removal stage of the project.

\begin{tabular}{|c|c|c|}
\hline \multicolumn{2}{|c|}{ Table 7. Manganate conversion during steam reforming } \\
\hline Gas Conditions & $\begin{array}{c}\text { Fixed } \\
\text { (i.e. char) carbon in smelt }\end{array}$ & $\begin{array}{c}\text { Experimental causticizing } \\
\text { conversion }\end{array}$ \\
\hline $50 \% \mathrm{H} 2 \mathrm{O}$ & $0.00 \%$ & $100 \%$ \\
\hline $50 \% \mathrm{H} 2 \mathrm{O}$ & $0.05 \%$ & $100 \%$ \\
\hline $50 \% \mathrm{H} 2 \mathrm{O}$ & $0.01 \%$ & $100 \%$ \\
\hline $50 \% \mathrm{H} 2 \mathrm{O}+10 \% \mathrm{CO} 2$ & $0.03 \%$ & $95 \%$ \\
\hline $50 \% \mathrm{H} 2 \mathrm{O}+10 \% \mathrm{CO} 2$ & $0.02 \%$ & $100 \%$ \\
\hline
\end{tabular}


The results for all of the cases are summarized in Table 8 below. Three of the six combinations will be retained for non-process element removal, and caustic recovery experiments. Chars from the successful causticizing processes above were hydrolyzed (leached) and titrated to measure the hydroxide recovered for comparison to the carbonate causticized.

\begin{tabular}{|c|l|l|}
\hline \multicolumn{2}{|c|}{ Table 8. } \\
\hline \multicolumn{2}{|c|}{ Summary Results of Causticizing Experiments } \\
\hline & $\begin{array}{l}600 \mathrm{C}, 50 \mathrm{hrs} \\
\text { Steam reforming }\end{array}$ & $\begin{array}{l}\text { 950C, 5sec using } \\
\text { CO2 and H2O }\end{array}$ \\
\hline $\begin{array}{c}\text { Titanates for 100\% } \\
\text { conv }\end{array}$ & $\begin{array}{l}\text { No; CO2 is too high in } \\
\text { product gas }\end{array}$ & $\begin{array}{l}\text { Works below 4-5 bar total } \\
\text { pressure. Good leaching } \\
\text { recovery }\end{array}$ \\
\hline $\begin{array}{c}\text { Borates for 20\% } \\
\text { conv }\end{array}$ & $\begin{array}{l}\text { No; CO2 is too high in } \\
\text { product gas }\end{array}$ & $\begin{array}{l}\text { Works below 2-3 bar total } \\
\text { pressure. Good leaching } \\
\text { recovery }\end{array}$ \\
\hline $\begin{array}{c}\text { Manganates for } \\
100 \% \text { conv }\end{array}$ & $\begin{array}{l}\text { No; achieved 100\% caust'n } \\
\text { but fails to reform Mn3O4 } \\
\text { during leaching. }\end{array}$ & No; zero causticizing \\
\hline
\end{tabular}

\section{Char Leaching}

Once the causticization conversion has been confirmed, the chars must be hydrolyzed (leached) to recover the hydroxide for pulping and return the agent back to a form where it can be returned to the gasifier and again causticize more carbonate. The overall process is shown in Figure 19. The amount of hydroxide formed during leaching must be compared to the carbonate consumed to verify material balance closure. Also the leached solids and leachate must be characterized to determine the fate of the non-process elements.

Three of the six variants considered thus far did not yield sufficient causticizing and were eliminated. The remaining three, shown in Table 9, were tested for caustic recovery to see if the $\mathrm{OH}$ formed matches the $\mathrm{CO} 3$ removed during gasification. This gives an indication that the causticizing agent returns to its initial state during hydrolysis and is ready for another cycle through the gasifier. The titanates yielded fairly good hydroxide recovery in most tests. Some low yields were observed however and remain unexplained. The borates yielded good recovery. The manganates consistently returned only $40 \%$ of the expected hydroxide. 


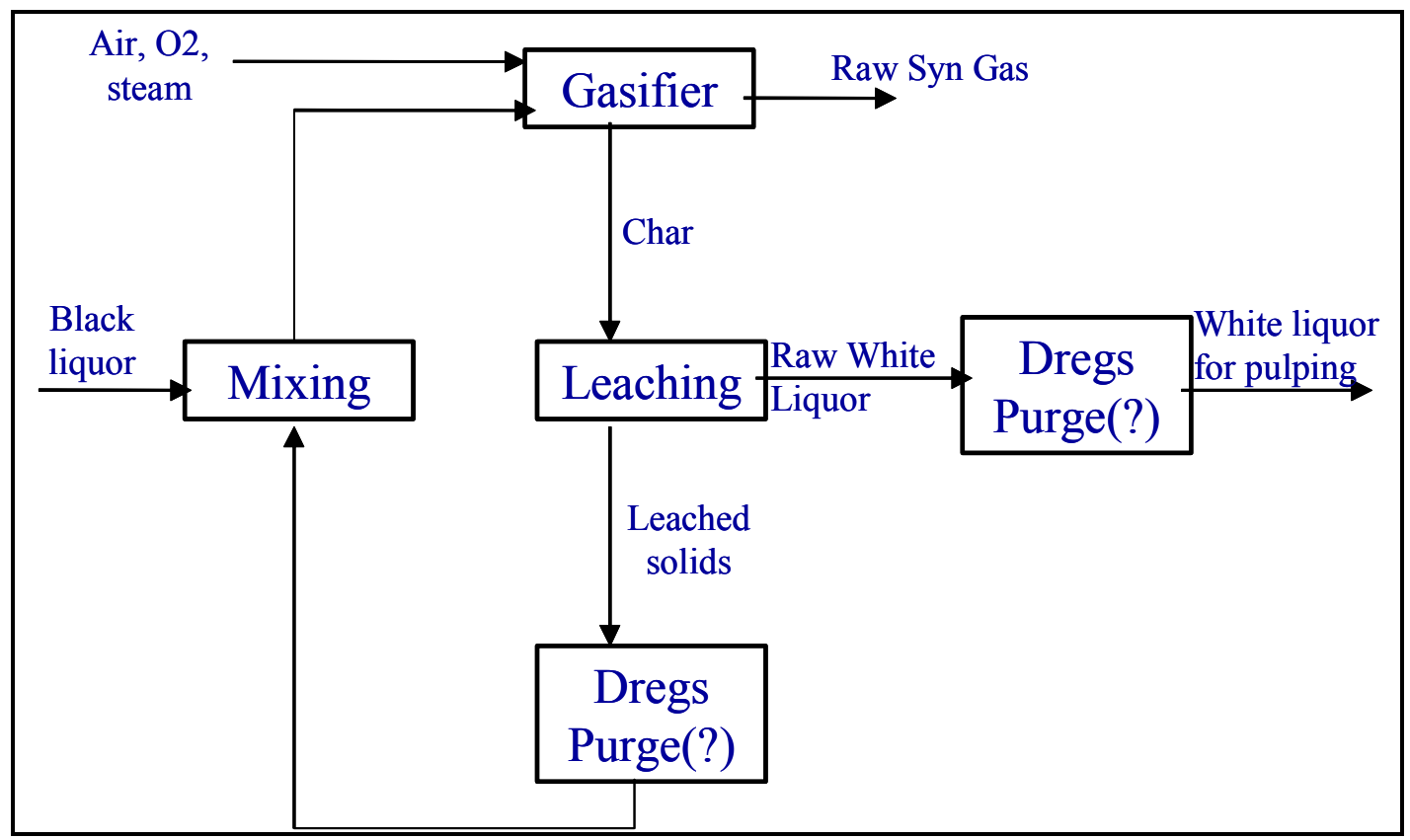

Figure 19. Hydroxide recovery and non-process element removal schematic

\begin{tabular}{|c|c|c|c|}
\hline \multicolumn{3}{|c|}{ Table 9. } \\
\hline & \# of runs & $\begin{array}{c}\text { Average } \% \mathrm{OH} \\
\text { recovered as \% of } \\
\text { maximum possible }\end{array}$ & Range of \% \\
\hline $\begin{array}{c}\text { Titanates for 100\% } \\
\text { conversion at HTBLG }\end{array}$ & 15 & $54 \%$ & $32-88 \%$ \\
\hline $\begin{array}{c}\text { Borates for 20\% conversion } \\
\text { at HTBLG }\end{array}$ & 5 & $18 \%$ & $16-20 \%$ \\
\hline $\begin{array}{c}\text { Manganates for 100\% } \\
\text { conversion at LTBLG }\end{array}$ & 5 & $39 \%$ & $38-40 \%$ \\
\hline
\end{tabular}

The apparent reason for the low hydroxide yield from the manganates is that some of the sodium and virtually all of the potassium are retained in the solid phase with the manganate despite two successive leachings for 90 minutes at $90^{\circ} \mathrm{C}$ (Table 10). The desired product should be pure $\mathrm{Mn3O} 4$ as shown in reaction (5) to obtain cyclic chemistry. If a significant portion of the causticizing agent is rendered inert in one cycle then cyclic chemistry cannot be maintained and the process is not viable. Manganates were therefore eliminated from further consideration, leaving no causticizing option for LTBLG. 


\begin{tabular}{|l|l|}
\hline \multicolumn{2}{|c|}{ Table 10 } \\
\hline Element & $\begin{array}{l}\text { \% of element in char found in } \\
\text { 2nd leached solid }\end{array}$ \\
\hline $\mathrm{Mn}$ & $98 \%$ \\
\hline $\mathrm{Na}$ & $29 \%$ \\
\hline $\mathrm{K}$ & $94 \%$ \\
\hline
\end{tabular}

Hydroxide recovery (in a single leaching step) for the titanate system varied from 32$88 \%$ (avg 55\%) of that expected. To improve recovery, multiple leachings were attempted. An example is shown in Table 11. While not all cases resulted in $98 \% \mathrm{OH}$ closure, factors such as particle agglomeration or sintering could be resolved with additional work.

\begin{tabular}{|l|l|}
\hline \multicolumn{2}{|c|}{ Table 11. Staged leaching results } \\
\hline Experiment & $\mathrm{D} 02 / 24 / 04$ \\
\hline OH recovered on 1st leaching & $86.1 \%$ \\
\hline OH recovered on 2nd leaching & $8.9 \%$ \\
\hline OH recovered on 3rd leaching & $3.6 \%$ \\
\hline Total of 3 stages & $98.6 \%$ (of the OH expt'd) \\
\hline
\end{tabular}




\section{XRD Analysis for Titanate Chars}

As an independent check to confirm the leaching is restoring the titanate to the forms expected in reactions (4) and (5), the char and subsequent leached solids were analyzed by X-ray Diffraction (XRD). Figure 20 shows the XRD spectra of titanate-doped black liquor gasified in $\mathrm{CO} 2$ at $950 \mathrm{C}$. The spectral signature of both the NT3 (same as $\mathrm{Na} 2 \mathrm{Ti3O}$ ) reactant form, and the N4T5 (shown as Na16Ti10O28) causticization product are both prominent. This suggests there was either incomplete causticization or an excess of NT3 in the system. Either way, reaction (2) is confirmed to occur. Additional XRD scans are included in the Appendix.

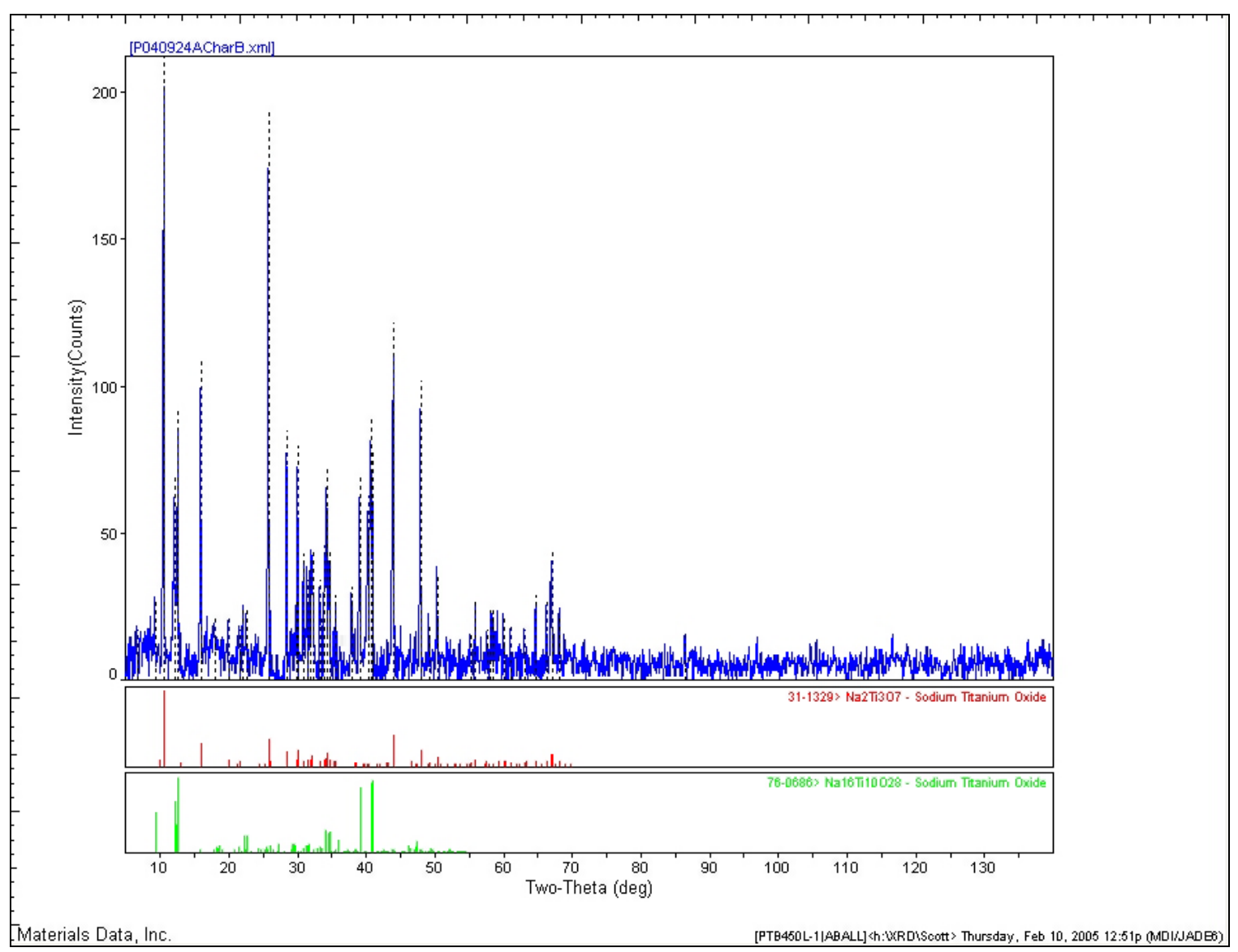

Figure 20. XRD spectra of titanate char before leaching

Figure 21 shows the XRD spectra of the same char from Figure 20 but after leaching. Note that N4T5 is not present but NT3 and a species with formula Na0.57Ti2O4 (equivalent to NT7, which is even better) are detected. From reaction (5), the form should be NT6 but the trend is the same in that the leaching step reduces the ratio of $\mathrm{Na} / \mathrm{Ti}$, while the causticizing step increases it. 


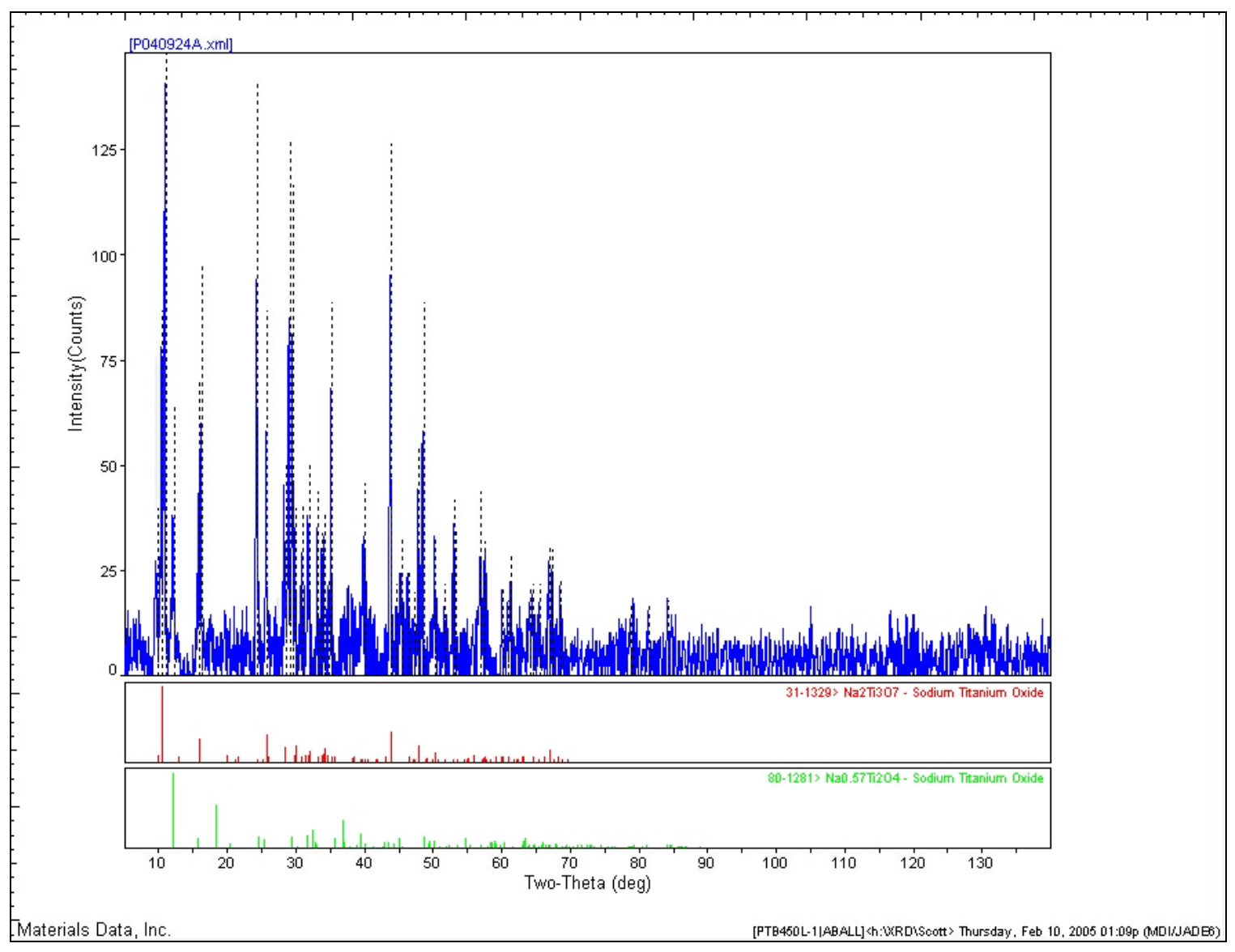

Figure 21. XRD of leached solids formed from leaching of char in Figure 20.

XRD data for the manganate case is irrelevant since manganates were eliminated. For the borate case, the char is soluble so there is no leached solid to examine. Confirmation of the borate chemistry is limited to disappearance of carbonate and appearance of hydroxide. 


\section{NPE Removal}

For the borate case, since the borates are soluble the NPE's can be removed as grits from the white liquor. Soluble NPE's such as potassium and chloride can be purged by purging a small amount of white liquor.

For the titanate case, the char, leached solids, and leachate (i.e. white liquor) were all analyzed by ICP to try and close the material balance on the NPE's. For major system species such as $\mathrm{Na}, \mathrm{K}, \mathrm{Ti}$, and $\mathrm{S}$, the material balance closed to within a few percent. For the trace metals of interest, such as Fe, $\mathrm{Al}, \mathrm{Si}, \mathrm{Ca}, \mathrm{Mg}, \mathrm{Ba}$, etc., the closure was not good enough to draw conclusions. An example is shown in Table 12. The poor closure may have been due to small sample sizes not representative of the bulk solids or incomplete acid digestion prior to analysis.

\begin{tabular}{|l|r|r|r|r|r|r|}
\hline \multicolumn{7}{|c|}{ Table 12. Elemental balance between char, leachate and solids for two successive } \\
\hline $\begin{array}{c}\text { ICP } \\
\text { element }\end{array}$ & $\begin{array}{r}\text { Char } \\
\text { ppm }\end{array}$ & $\begin{array}{r}\text { Leached } \\
\text { Solid ppm }\end{array}$ & $\begin{array}{c}\text { to solid } \\
\text { phase }\end{array}$ & $\begin{array}{c}\text { 1st leachate } \\
\text { ppm }\end{array}$ & $\begin{array}{c}\text { 2nd leachate } \\
\text { ppm }\end{array}$ & $\begin{array}{c}\text { Mat'l bal } \\
\% \text { error }\end{array}$ \\
\hline $\mathrm{Al}$ & 397 & 121 & $31 \%$ & 1177 & 30 & $-234 \%$ \\
\hline $\mathrm{B}$ & 48 & 13 & $28 \%$ & 2495 & 509 & $-6217 \%$ \\
\hline $\mathrm{Ca}$ & 530 & 683 & $129 \%$ & 114 & 74 & $-64 \%$ \\
\hline $\mathrm{Cr}$ & 77 & 7 & $9 \%$ & 62 & 2 & $9 \%$ \\
\hline $\mathrm{Cu}$ & 30 & 23 & $76 \%$ & 5 & 8 & $-17 \%$ \\
\hline $\mathrm{Fe}$ & 572 & 613 & $107 \%$ & 15 & 10 & $-11 \%$ \\
\hline $\mathrm{K}$ & 15500 & 2353 & $15 \%$ & 13433 & 215 & $-3 \%$ \\
\hline $\mathrm{Mg}$ & 11 & 141 & $1322 \%$ & 15 & 10 & $-1456 \%$ \\
\hline $\mathrm{Mn}$ & 131 & 150 & $115 \%$ & 1 & 0 & $-15 \%$ \\
\hline $\mathrm{Mo}$ & 7 & 7 & $89 \%$ & 11 & 7 & $-223 \%$ \\
\hline $\mathrm{Na}$ & 26600 & 61587 & $23 \%$ & 197457 & 8787 & $-1 \%$ \\
\hline $\mathrm{S}$ & 23200 & 155 & $1 \%$ & 23180 & 155 & $-1 \%$ \\
\hline $\mathrm{Sb}$ & 213 & 21 & $10 \%$ & 34 & 21 & $65 \%$ \\
\hline $\mathrm{Si}$ & 1210 & 247 & $20 \%$ & 22877 & 2558 & $-202 \%$ \\
\hline $\mathrm{Ti}$ & 282000 & 291692 & $103 \%$ & 4 & 7 & $-3 \%$ \\
\hline $\mathrm{V}$ & 203 & 3 & $2 \%$ & 31 & 1 & $83 \%$ \\
\hline
\end{tabular}




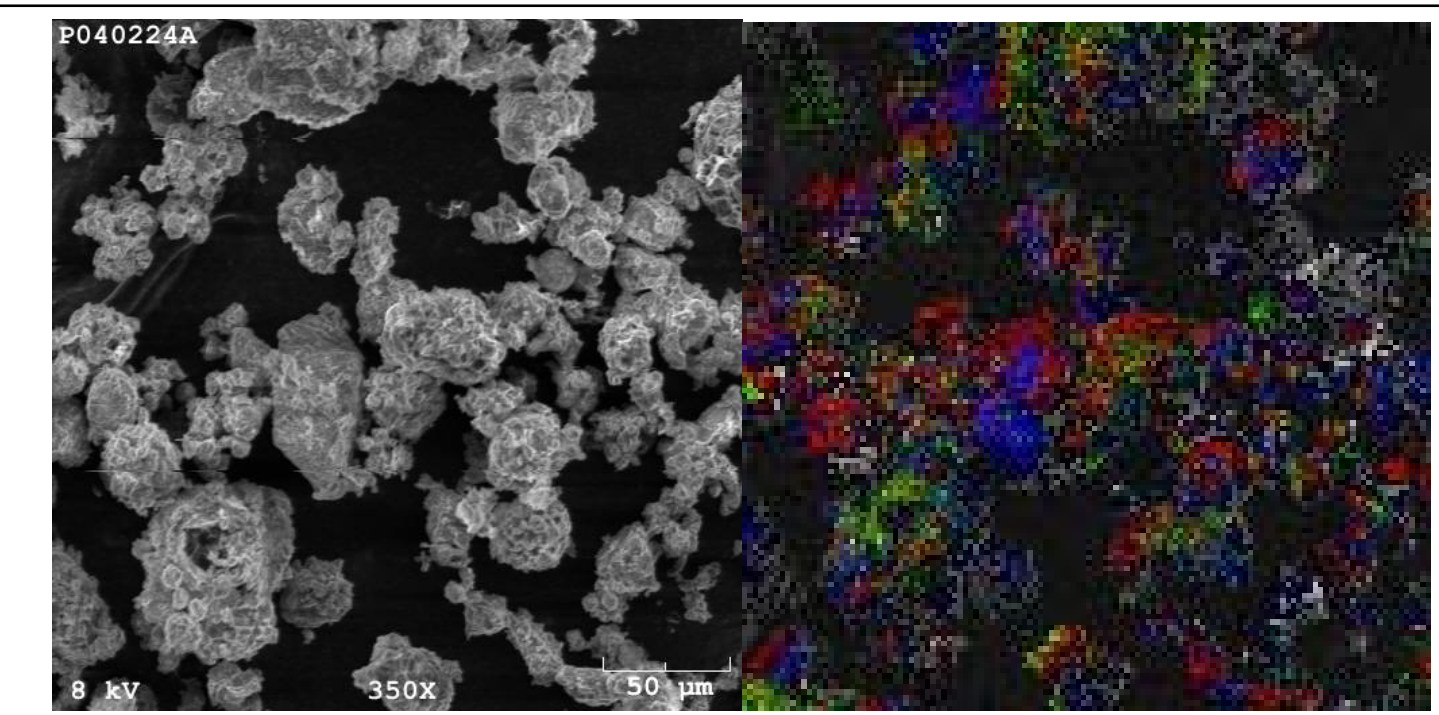

Figure 22. Above left is the SEM-EDS micrograph (titanate leached solids from run P040224A) with 50 micron size reference bar shown. On the left is the same image with major surface species concentrations shown in colors. Below are the same regions shown for each species. Note that while sulfur appears to be abundant, only $0.7 \%$ of the sulfur in the char remained with the solids after leaching.

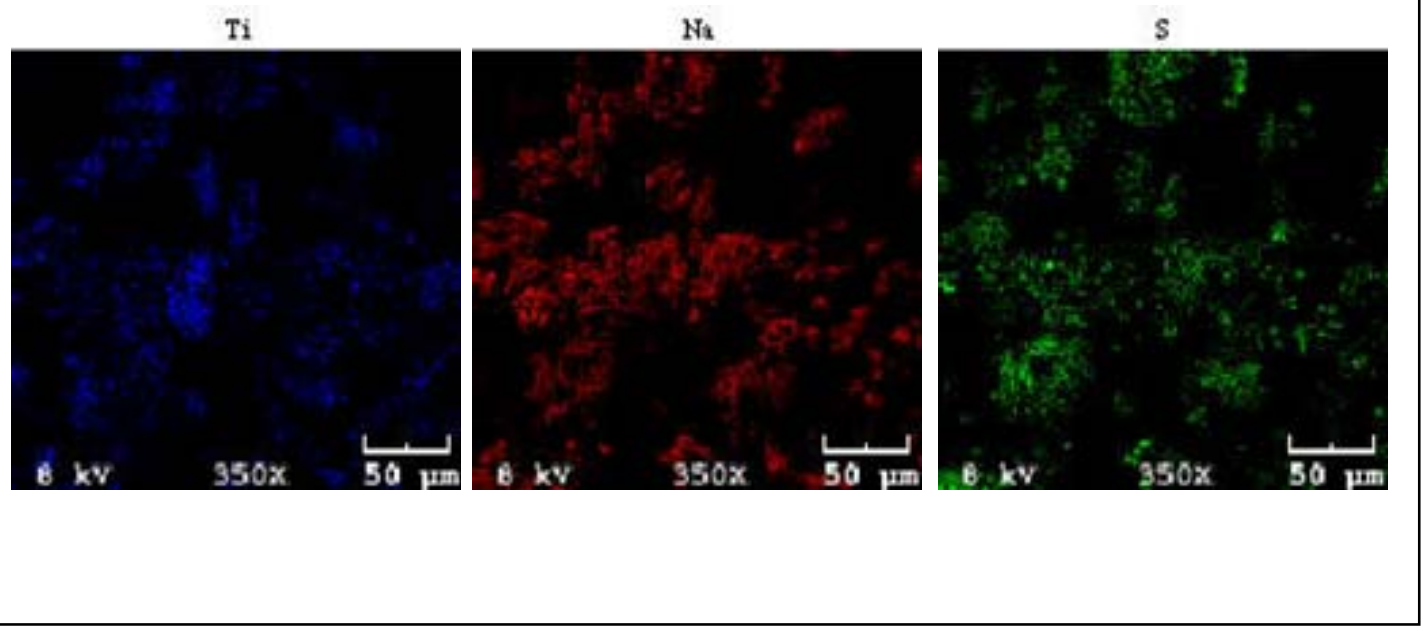




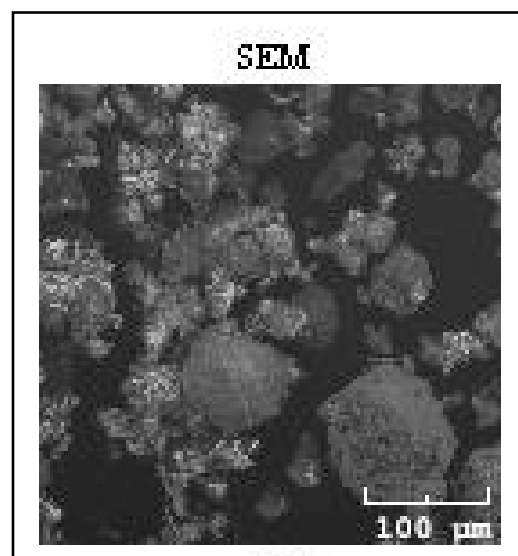

$\mathrm{Na}$

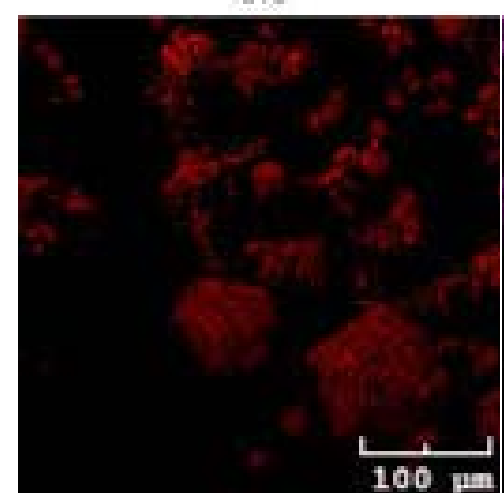

$\mathrm{Si}$

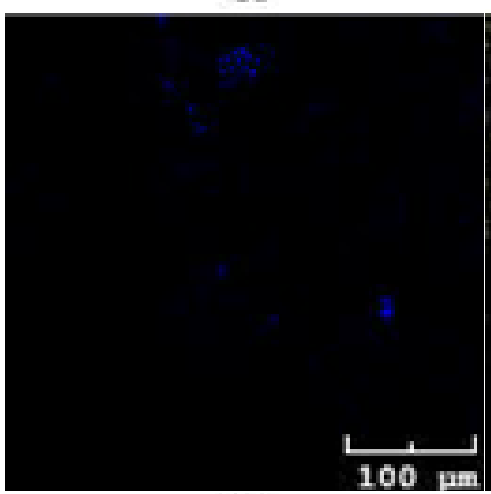

Fe
Figure 23. Experiment P040224A. The reference SEM is at left. Each element is color coded in the figures below. It must be viewed in color. Note most of the NPE's such as Fe, $\mathrm{Si}$, etc., appear as point sources on the surface of other particles. Density-based separation removal processes will not be effective at this level of mixture.

S

Ti

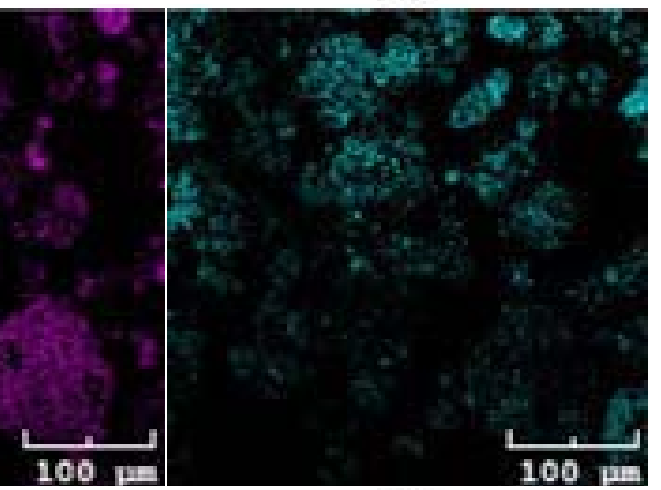

$\mathrm{K}$

Al

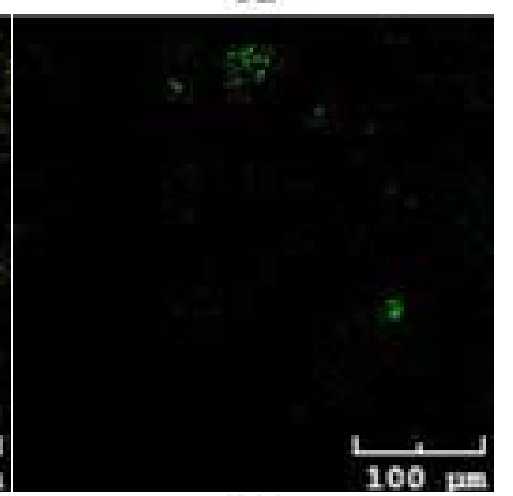

In

$\mathrm{Sn}$

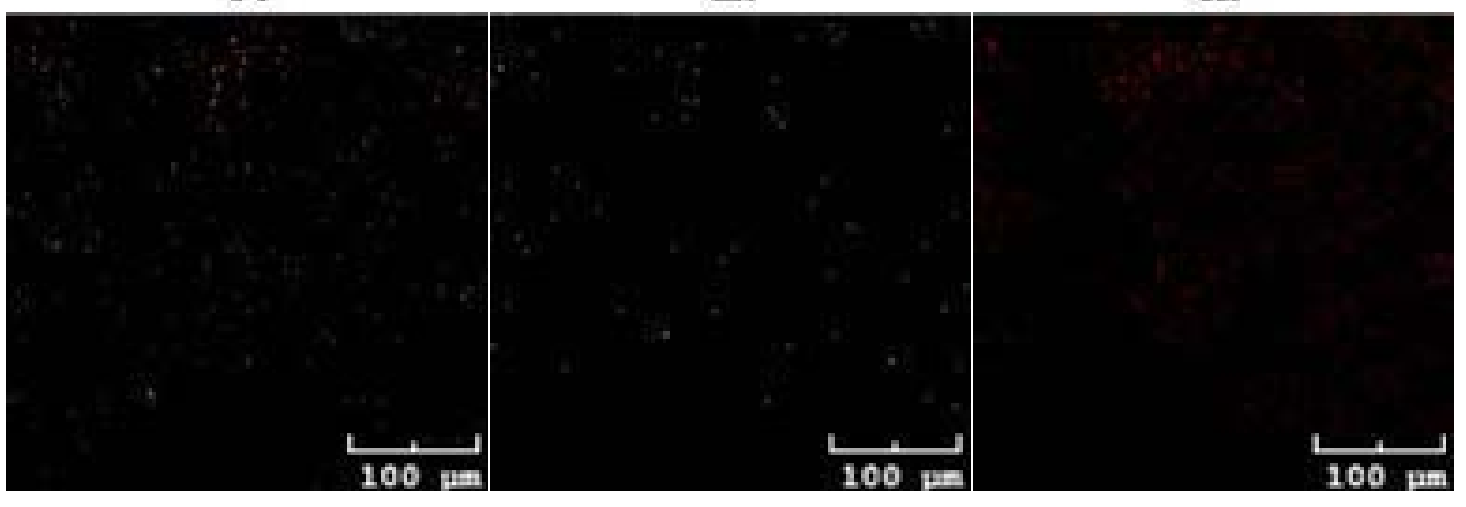


In any case, there must be an NPE purge mechanism. There are two approaches: 1) chemical separation (acid treatment, or metal complexing), or 2) size or density based techniques as used in the mining industry.

To try and narrow the options, SEM EDS was carried out on samples of leached Ti solids (Figures 22 and 23). In this analysis several SEM images are taken of the same area, as shown in Figures 22 and 23, with each photo color-coded to show only one element (e.g. $\mathrm{Fe}, \mathrm{Si}$, etc.). They require a color medium to interpret results so they are not shown here. What they reveal is that while species such as $\mathrm{Na}, \mathrm{K}$, and $\mathrm{S}$ are uniformly distributed over each particle, some of the NPE's are concentrated on a few particles, and others appear as points appearing on nearly every particle.

We conclude from the SEM-EDS that the NPE's are intimately bound to the particles, and thus any size or density based separation technique is not likely to work. This leaves us with chemical techniques. The simplest option in the case of Ti solids is to titrate with an acid. Ti remains solid down to very low $\mathrm{pH}$; lower than the NPE's we wish to remove, as shown in Table 13.

\begin{tabular}{|l|l|}
\hline \multicolumn{2}{|c|}{ Table 13. $\mathrm{pH}$ precipitation points } \\
\hline Metal & $\mathrm{pH}$ \\
\hline $\mathrm{Ca}^{++}, \mathrm{Mg}^{++}$ & $10-11$ \\
\hline $\mathrm{Mn}$ & $8-9$ \\
\hline $\mathrm{Fe}$ & 7 \\
\hline $\mathrm{Zn}, \mathrm{Cu}$ & 6 \\
\hline $\mathrm{Al}$ & $4-5$ \\
\hline $\mathrm{Fe}$ & $2-3$ \\
\hline $\mathrm{Ti}$ & 2 \\
\hline
\end{tabular}

FactSage 5.4 was used to simulate the titration prior to lab testing. $\mathrm{HCl}, \mathrm{HNO}_{3}$, and $\mathrm{H}_{2} \mathrm{SO}_{4}$ were considered (Table 14). The latter two failed to dissolve $\mathrm{BaSO}_{4}$. Only $\mathrm{HCl}$ produced clean NT3 in the simulation. Lab testing confirmed that all NPE's were removed by $\mathrm{HCl}$ titration.

\begin{tabular}{|c|c|}
\hline & Do \\
\hline $\mathrm{H} 2 \mathrm{SO} 4$ & $\begin{array}{l}\text { TiO2, CaSO4, BaSO4 remained } \\
\text { in solid phase }\end{array}$ \\
\hline HNO3 & $\begin{array}{l}\mathrm{TiO} 2, \mathrm{Fe} 2 \mathrm{O} 3, \mathrm{BaSO} 4 \text { remained } \\
\text { in solid phase }\end{array}$ \\
\hline $\mathrm{HCl}$ & $\mathrm{TiO} 2$ is the only solid \\
\hline
\end{tabular}




\section{Mill Integration and Economic Evaluation}

The final phase of the project was a mill integration study to develop the most likely process configuration for the borate and titanate options based on the reference mill design basis, perform capital cost estimates for the options, and then to perform economic evaluations for the options as compared to the base case. The base case is pressurized HTBLG with a conventional causticizing operation that has been upgraded with oxygen enriched fuel oil firing in the lime kiln. The reference mill basis used for this study is the same as that used by Larson et al. [28]. The study by Larson et al. was quite thorough and provides an excellent benchmark to assess just the in situ causticizing option of a BLG based mill. The Larson mill is an integrated pulp and paper mill producing uncoated freesheet paper from a 65/35 mix of hardwood and softwood. The mill produces about 5.4 MM lbs/day of black liquor solids (BLS). The HTBLG case data from the Larson Study is used for the base case in this study. Detailed mill data and assumptions can be found in the report by Larson et al. [28].

\section{The Base Case}

The base case process is based on HTBLG followed by conventional calcium oxide causticizing. Since HTBLG will increase smelt sodium carbonate, the lime requirement for slaking increases by a like amount. Larson et al. [28] assumes a conservative increase of $16 \%$, although this number will vary with gasification conditions, sulfur split, and sulfur recovery technique. This puts an increase load on the lime kiln. Considering that many mills are kiln limited and the hypothetical mill is at its kiln design limit, Larson et al [28] includes oxygen enrichment, a new kiln burner system, and new refractory brick to increase the kiln capacity.

\section{Borate Autocausticization Case}

Borate autocausticizing is a partial causticization process $(20 \%$ of lime is replaced with borate). This means that the conventional lime caustic plant continues to run but at a reduced rate. Borate in the form of sodium tetraborate pentahydrate $\left(\mathrm{Na}_{2} \mathrm{~B}_{4} \mathrm{O}_{7} \cdot 5 \mathrm{H}_{2} \mathrm{O}\right)$ is added to the liquor system to achieve the desired level of lime substitution. Once this level is achieved, borate can be made up to the liquor system in small amounts to account for natural system losses [7]. The borate is fed to a small mix tank from a supersack/screw feeder. A side stream of clarified green liquor is sent to the mix tank to dissolve and absorb the borate. This green liquor/borate stream then flows to the slaker by gravity. A spreadsheet balance was used to develop the chemical flows and borate makeup. Borate makeup is based on lime substitution, lime availability, white liquor causticity, borate loss rate, and borate reaction efficiency

\section{Titanate Direct Causticizing Case}

Titanate direct causticizing is for full $100 \%$ substitution of lime, hence, the conventional caustic plant is shut down. The envisioned overall process is shown in Figure 24. For the economical use of titanate, it must be recovered and recycled back to the black liquor prior to gasification. Following smelt dissolving, titanate remains in the green liquor as a suspended solid. By assuming physical properties of the titanate being similar to lime mud, we can extrapolate to a mill-scale process utilizing three staged leaching tanks for 
reaction residence time with each stage followed by disc filtration. The green liquor/titanate slurry goes to a first stage leaching tank. The leaching tank is agitated to keep the solids in suspension. Each tank is sized for 60 minutes of residence time to allow adequate mass transfer and leaching of the sodium hydroxide. From the first stage leaching tank, the slurry is pumped to a disc filter. Solids discharge from the filter at $85 \%$ solids. The filtrate from the first stage filtrate tank is essentially white liquor that is transferred to the digester area. The first stage filter discharge solids are diluted and gravity fed to the second stage leaching tank. The second and third leaching stages are configured the same as the first stage. Note that only a single leaching stage is shown in Figure 4 but more could be added as needed. Filtrate moves countercurrent to the solids flow through the system. Hot water or evaporator condensate is added to the third stage filter showers. Titanate solids off the third stage filter are conveyed to a black liquor mix tank prior to the gasifier. Note that two leaching stages are very likely sufficient but three were used for a conservative analysis.

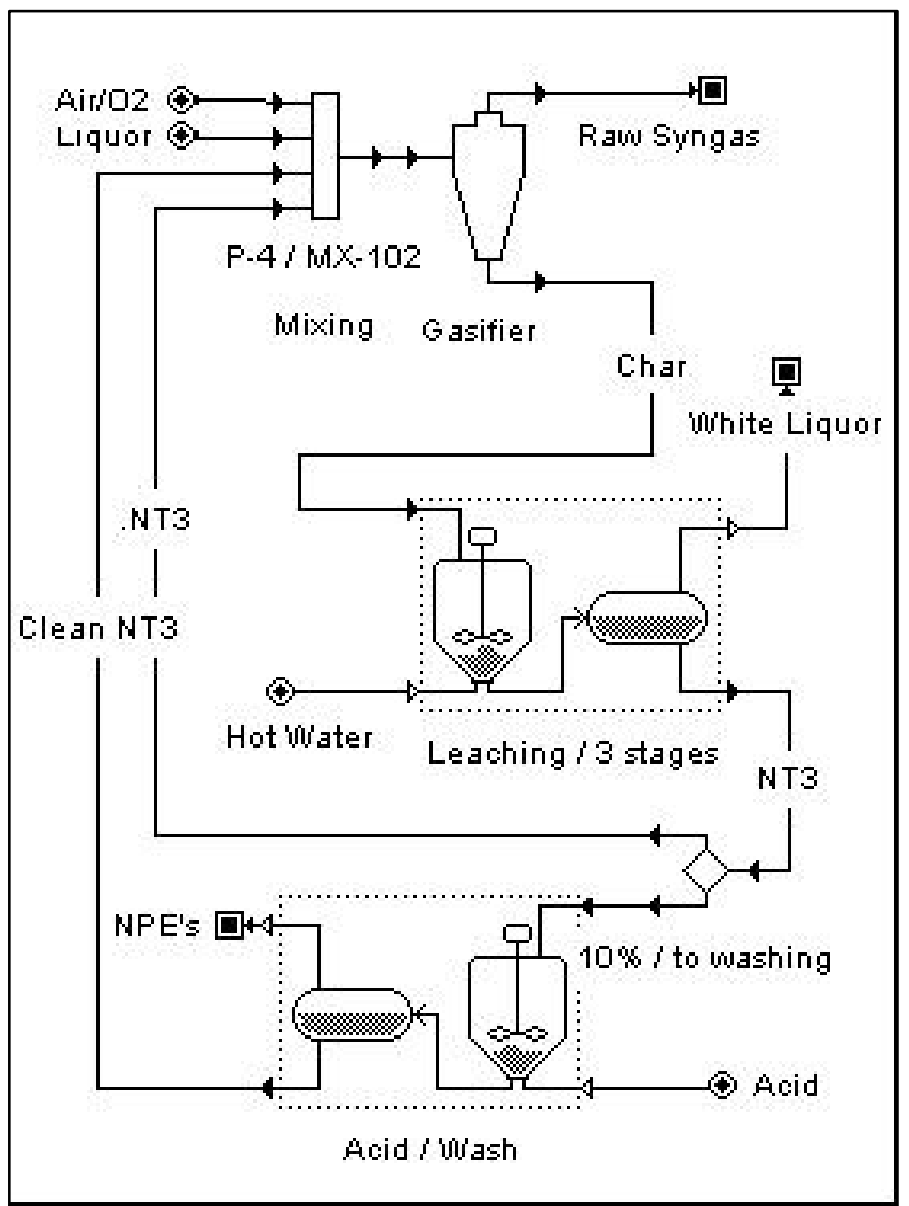

Figure 24. BLG with Ti-direct causticizing and acid treatment to purge NPE's. Circles are feed streams; squares are product.

A portion of the titanate solids stream $(10 \%)$ is transferred to an acid slurry mix tank. The purpose of the acid slurry tank is to mix hydrochloric acid with the titanate solids. The acid leaches out the NPE's from the titanate. The acid slurry is transferred to a disc 
filter. Filtrate from the NPE purge filter flows by gravity to the NPE purge filtrate tank. Caustic is added to neutralize the acid. The neutralized filtrate then flows to the sewer. Solids from the NPE purge filter are conveyed to a new black liquor mix tank. Titanium dioxide makeup is added to the black liquor mix tank as well via the screw conveyor. It is assumed that the mill already has available hydrochloric acid and caustic make-down and delivery systems.

Potassium remains in the system either as potassium titanate or potassium hydroxide and carbonate. Potassium lowers the melting point of recovery boiler ash and is a primary cause of boiler tube pluggage in Tomlison recovery boilers. In a HTBLG system, the potassium poses no problem.

A new agitated heavy $(50 \%)$ black liquor mix tank is required to recycle the titanate prior to the black liquor concentrator. This allows the $85 \%$ solids titanate recycle stream to be uniformly mixed prior to concentrating the black liquor to $80 \%$ solids for gasification. The titanate suspended solids flow is substantial, adding about $40 \%$ to the overall mass flow of the black liquor. The black liquor volume flow increases about $20 \%$. Although no increase to the evaporation capacity of the black liquor concentrator is required, modifications are required to increase the hydraulic capacity. Primarily pump and motor upgrades are required. An allowance is included in the capital estimate to cover concentrator upgrades for the increased liquor flow. The additional suspended solids should enhance the crystallization process and reduce fouling for $80 \%$ solids liquor production by providing sites for crystallization to take place rather than on heat transfer surface areas.

A material and energy balance was performed to calculate material flows and temperatures for the titanate recovery and NPE purge process (Table 15). The balance is

\begin{tabular}{|l|r|}
\hline \multicolumn{2}{|c|}{ TABLE 15. TITANATE BALANCE BASIS AND ASSUMPTIONS } \\
\hline Smelt & (w/o potassium) \\
\hline $\mathrm{Na}_{2} \mathrm{CO}_{3}, \mathrm{mt} / \mathrm{hr}$ & 4.76 \\
\hline $\mathrm{NaOH}, \mathrm{mt} / \mathrm{hr}$ & 0.79 \\
\hline $\mathrm{Na}_{2} \mathrm{~S}, \mathrm{mt} / \mathrm{hr}$ & 4.73 \\
\hline $\mathrm{HCl}, \mathrm{mt} / \mathrm{hr}$ & 0 \\
\hline $\mathrm{NPE}$ 's (Dissolved), $\mathrm{mt} / \mathrm{hr}$ & 3.15 \\
\hline Inerts (Suspended), $\mathrm{mt} / \mathrm{hr}$ & 1.46 \\
\hline Black Liquor Sodium Carbonate Converted, \% & 88.0 \\
\hline 1st Leaching Stage Caustic Recovery, \% & 86.1 \\
\hline 2nd Leaching Stage Caustic Recovery, \% & 8.9 \\
\hline 3rd Leaching Stage Caustic Recovery, \% & 3.6 \\
\hline Titanate Split to NPE Purge, \% & 10 \\
\hline HCl ratio to Treated Solids, kg/kg & 0.1 \\
\hline
\end{tabular}

based on HTBLG smelt chemical flow data from the Larson et al. [28] and stoichiometric titanate requirements for causticization. In addition, results from IPST experimental data were also used for the balance around the caustic leaching stages and the NPE acid 
leaching stage. Table IV shows the basis and assumptions for executing the material and energy balance for the Titanate case.

The Titanate split to acid treatment for NPE purge was varied to observe the effect on the steady-state level of NPE's in the recycled titanate. Figure 25 shows the effect on NPE levels at different purge fractions. At 5\% fraction to acid treatment, the NPE's level in the recycled titanate is $23 \%$. A higher level of NPE's in the system means a higher deadload through the process. This causes higher loads on the causticizing equipment and higher hydraulic/pumping loads on the black liquor concentrator system. Of course the acid and caustic costs decrease, but there is still more operational risk with the higher dead-load through the process. At $10 \%$ fraction to acid treatment, the NPE's level decreases to $15 \%$. Further increases in acid treatment fractions yield lower decreases in the NPE's level. It appears that $10 \%$ fraction to acid treatment is good conservative minimum for the purpose of this mill integration study. In a traditional lime based causticizing system, the amount of NPE's or inerts carried in the reburned lime is typically 10 to $15 \%$ as well.

Note also that three leaching stages were used to recover $98.6 \%$ of the hydroxide (Table IV). Conventional lime cycles are not this efficient. It is likely that two or even one leaching stage could be employed. However conservative estimates were desired for this study.

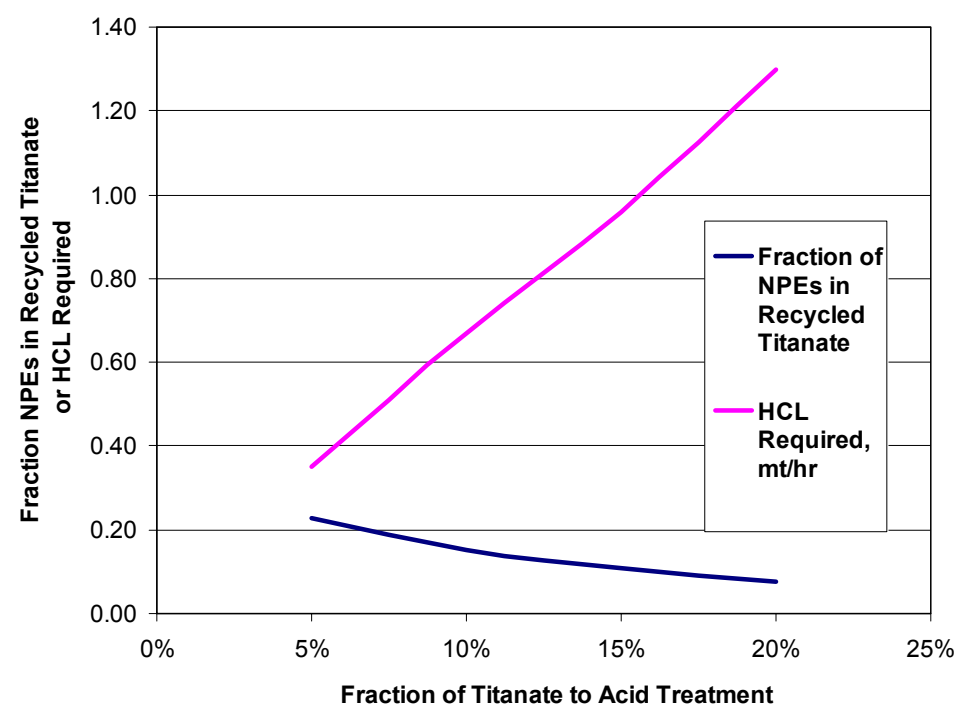

Figure 25. NPE acid treatment sensitivity analysis

\section{Water Balance}

Water usages for the three options are compared in Figure 26 along with a base case that uses a scrubber on the kiln flue gas instead of an electrostatic precipitator (ESP). The state of the art mill with an ESP on the lime kiln flue gas uses minimal water because the recycle lime dust is returned dry. The base case assumes a state of the art mill with a lime kiln ESP. The borate case water usage is even less due to a lower lime requirement. 
The base case with a conventional kiln scrubber has the highest water usage due to evaporative losses. The titanate case water usage is an improvement upon a kiln scrubber but it does require more water than the base case with a kiln ESP.

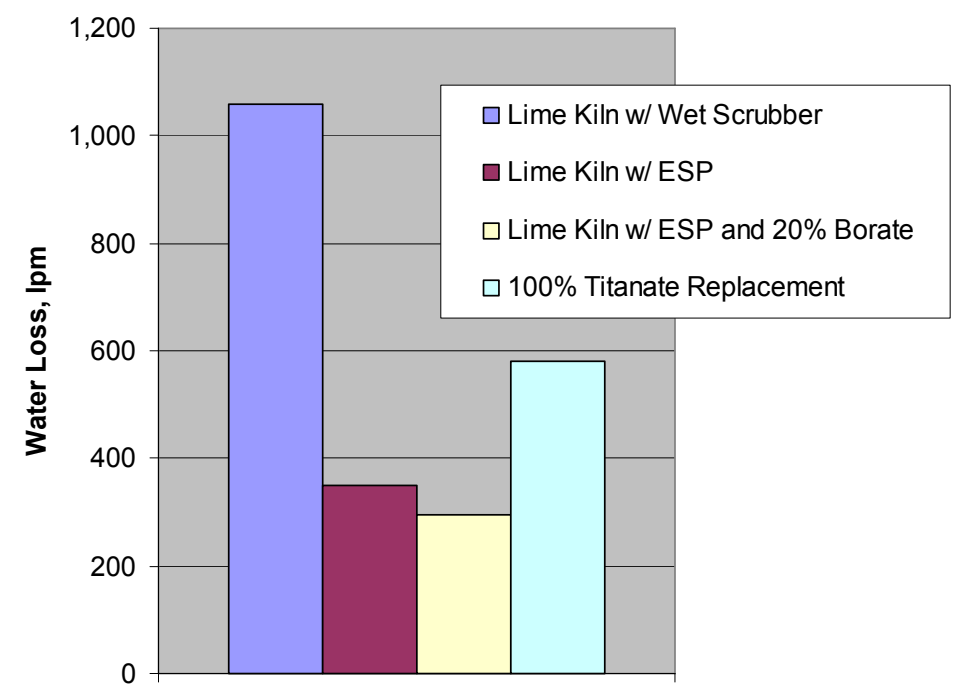

Figure 26. Causticizing process water balance.

\section{Capital and Operating Cost Summary}

The capital cost estimates are $\pm 30 \%$ accuracy factored total installed cost (TIC). The estimates are based on preliminary process flow diagrams, priced equipment lists, and project scope descriptions. Equipment pricing was obtained from Andritz for disc filters and leaching tank agitators. Pump pricing was obtained from ITT Goulds. All other equipment pricing was obtained from historical database of recent projects with similar equipment. Piping, structural, electrical, and controls material and equipment were factored based on the process equipment direct cost. The estimates assume an engineering, procurement, and construction management (EPC) type contract to execute the project. The estimates assume a site in the southeastern United States, non-union, and no escalation is included. The capital cost estimates are summarized in Table 16. The base case capital cost is taken from Larson et al. [28] and factored up to account for inflation from 2002 to 2006.

\begin{tabular}{|l|c|}
\hline \multicolumn{2}{|l|}{ TABLE 16. CAPITAL COST SUMMARY } \\
\hline Case & \$MM U.S. \\
\hline Base & 1.20 \\
\hline Borate & 0.17 \\
\hline Titanate (3-stage leaching) & 31.55 \\
\hline
\end{tabular}


The operating and maintenance costs for each option are estimated from the following sources of information:

- $\quad$ Chemicals usages from M\&E balances (Table 17)

- $\quad$ Lime kiln fuel oil usage for HTBLG [28]

- Electricity usage based on total connected equipment horsepower times $80 \%$ for each case (Table 18)

- Chemicals, fuel oil, and electricity costs from current market pricing (August, 2006) (Table 18)

- Annual maintenance cost equal to $5 \%$ of capital cost

\begin{tabular}{|l|l|}
\hline \multicolumn{2}{|l|}{ TABLE 17. CHEMICALS, FUEL, AND ELECTRICITY COSTS (2006) } \\
\hline \#6 Fuel Oil , \$/MMBTU & $\$ 8.51$ \\
\hline Electricity, \$/MWh & $\$ 58.60$ \\
\hline Borate, $\$ / \mathrm{mt}$ & $\$ 425.00$ \\
\hline Titanium Dioxide, $\$ / \mathrm{mt}$ & $\$ 480.00$ \\
\hline Hydrochloric Acid, $\$ \mathrm{mt}$ & $\$ 135.00$ \\
\hline Sodium Hydroxide, $\$ / \mathrm{mt}$ & $\$ 370.00$ \\
\hline (note: $\mathrm{mt}=$ metric ton, MM=million, MW=megawatt) \\
\hline
\end{tabular}

\begin{tabular}{|r|r|r|l|}
\hline \multicolumn{5}{|c|}{ TABLE 18. EXPERIMENTAL CONDITIONS } \\
\hline & Borate & Titanate & \\
\hline Fuel Oil Savings & 217,386 & $1,086,928$ & MMBTU/yr \\
\hline Electricity Savings & 4,310 & 7,038 & $\mathrm{MWhr} / \mathrm{yr}$ \\
\hline Borate Usage & 1,177 & & $\mathrm{mt} / \mathrm{yr}$ \\
\hline Titanium Dioxide & & 3,951 & $\mathrm{mt} / \mathrm{yr}$ \\
\hline Hydrochloric Acid & & 5,559 & $\mathrm{mt} / \mathrm{yr}$ \\
\hline Sodium Hydroxide & & 3,912 & $\mathrm{mt} / \mathrm{yr}$ \\
\hline
\end{tabular}

Table 19 shows the costs or savings items for each option. Avoided cost savings are treated as positive cash flow. The annual maintenance cost for the base case is based on $5 \%$ of the capital cost of a new lime kiln and caustic plant of similar capacity. The order of magnitude capital cost of a new lime kiln and caustic plant is approximately $\$ 35,000,000$. Note that if this were a greenfield comparison, the cost of a new lime cycle would make the titanate option far more attractive. 


\begin{tabular}{|c|c|r|r|}
\hline \multicolumn{4}{|c|}{ TABLE 19. ANNUAL O \& M COSTS } \\
\hline & Base & \multicolumn{1}{c|}{ Borate } & Titanate \\
\hline Avoided Costs & & & \\
\hline Avoided kiln fuel & & $1,849,503$ & $9,247,514$ \\
\hline Avoided elec & & 252,567 & 412,428 \\
\hline Total & & $2,102,070$ & $9,659,943$ \\
\hline & & & \\
\hline Direct Op Costs & & & \\
\hline Borate & & 500,288 & \\
\hline Titanate & & & $1,896,391$ \\
\hline HCl & & & 750,454 \\
\hline NaOH & & & $1,447,375$ \\
\hline $\begin{array}{l}\text { Inc waste treat } \\
(.10 \mathrm{~kW} / \mathrm{lpm})\end{array}$ & & & 29,809 \\
\hline Op \& Maint. & $1,750,000$ & $1,408,700$ & $1,577,250$ \\
\hline Total & $1,750,000$ & $1,908,988$ & $5,701,279$ \\
\hline
\end{tabular}

\section{Economic Analysis}

Both the internal rate of return (IRR) and net present value (NPV) analyses were performed on each case and also performed relative to the base case. The key inputs to the analyses are the capital costs and the annualized operating and maintenance costs. Table 20 shows the economic assumptions used for the analyses.

\begin{tabular}{|l|l|}
\hline \multicolumn{2}{|c|}{ TABLE 20. ECONOMIC ASSUMPTIONS } \\
\hline Financial Parameters & \\
\hline Annual Inflation Rate & $4.0 \%$ \\
\hline Debt Fraction of Capital & $50 \%$ \\
\hline Equity Fraction of Capital & $50 \%$ \\
\hline Interest Rate on Debt & $8.0 \%$ \\
\hline Return on Equity & $15 \%$ \\
\hline Resulting Discount Rate used for NPV calculations & $9.9 \%$ (after tax) \\
\hline Income Tax Rate (combined Federal \& State) & $40 \%$ \\
\hline Economic Life (years) & 25 \\
\hline Depreciation Method & 20 -year MACRS rate schedule \\
\hline Construction Time & 1 yr \\
\hline Mill Assumptions & \\
\hline Annual Operating Hours & 8,330 \\
\hline Annual O\&M Costs, \% of Capital Cost & $5 \%$ \\
\hline Start-up Assumptions & \\
\hline Year 1 of Operation & $100 \%$ \\
\hline \multicolumn{2}{|l}{} \\
\hline (1 - Modified Accelerated Cost Recovery System (MACRS) per IRS Tax Code) \\
\hline
\end{tabular}


The IRR and NPV cash flow analyses were performed for each case and for relative comparison to the HTBLG base case. Total net cash flows are shown in Table 21. The stand-alone base case is taken directly from Larson et.al. [28]. The numbers for the stand-alone borate and titanate cases are incremental beyond the base.

\begin{tabular}{|l|c|c|c|c|}
\hline \multicolumn{5}{|c|}{ TABLE 21. TOTAL NET CASH FLOW } \\
\hline & \multicolumn{2}{|c|}{ Stand-Alone } & \multicolumn{2}{c|}{ Relative to Base } \\
\hline & IRR & NPV & IRR & NPV \\
& $(\%)$ & $(\$ \mathrm{MM})$ & $(\%)$ & $(\$ \mathrm{MM})$ \\
\hline Base - HTBLG & $16 \%$ & 72.8 & N/A & 0 \\
\hline Borate & $135 \%$ & 1.4 & N/A & 16.1 \\
\hline $\begin{array}{l}\text { Titanate } \\
\text { (3-stage leach) }\end{array}$ & $15.9 \%$ & 10.6 & $23.9 \%$ & 25.2 \\
\hline
\end{tabular}

Considering the stand-alone NPVs over the total project life of 25 years, the titanate option clearly has the best NPV of $\$ 10.6 \mathrm{MM}$ primarily from the substantial fuel savings over the base case. The borate option has a high stand-alone IRR of $135 \%$ due to the minimal capital investment required. The borate option still achieves $20 \%$ of the fuel savings of the titanate option. Relative to the base case the titanate option is more economically attractive with an NPV of $\$ 25.2 \mathrm{MM}$ and an IRR of $23.9 \%$.

The titanate carries some technical risks though because it is a new technology. The performance of titanate as a direct causticizing agent and the subsequent acid purging of NPE's was proven successful on the lab scale. Some basic assumptions are made about the titanate char physical properties in order to configure the process presented in this report. The actual performance of the process must be determined through pilot plant trials to refine the process configuration and minimize risk (e.g. two leaching stages will likely suffice). Hence, the capital cost could vary depending on the final process scope from pilot plant work. Borate, on the other hand, has been proven effective in conventional Tomlinson based recovery cycles but only for partial auto-causticization.

Figure 27 shows IRR sensitivity to titanate capital cost variance at varying fuel oil prices. Fuel oil price variance has a significant effect on the IRR. If fuel oil price rises to $\$ 10$ per MMBTU, then the IRR will increase from $23.9 \%$ to $31 \%$. 


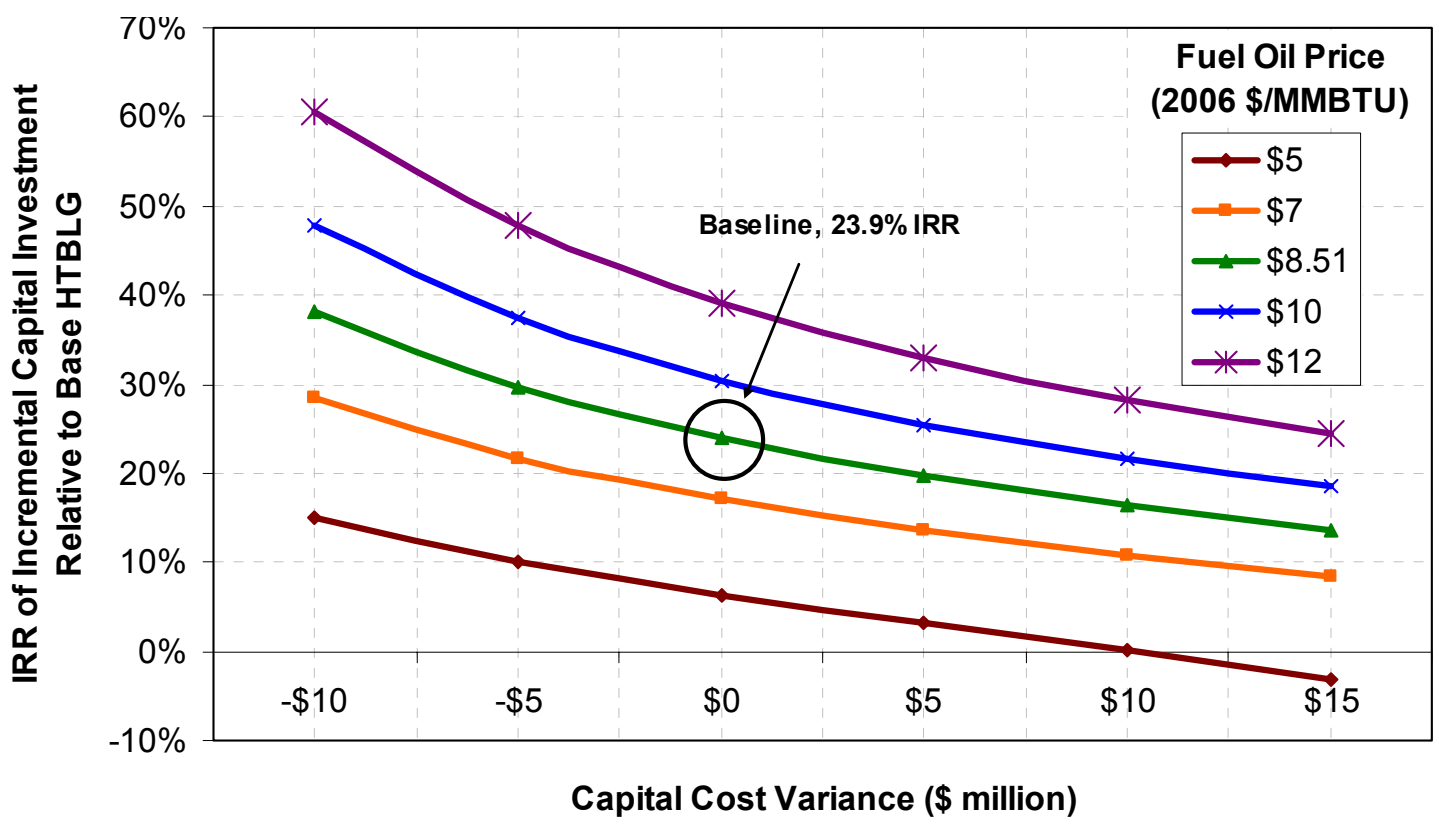

Figure 27. Fuel oil and capital cost sensitivity analysis.

On the other hand a significant drop in fuel oil price will severely negate the economics of titanate as well. Therefore, fuel price trends must be carefully analyzed to predict economic performance for future projects.

\section{CONCLUSIONS}

The borate and titanate options are both effective auto and direct causticizing agents, respectively, within the pressure and temperature limits found in this study. Borate carries minimal capital investment and provides attractive payback and economics by alleviating the additional burden on the lime cycle that HTBLG causes and by saving some kiln fuel oil cost.

Titanate can replace up to $100 \%$ of the lime cycle and provide equal white liquor quality. This has been demonstrated on the lab scale. By assuming physical properties of the titanate being similar to lime mud we can extrapolate to a mill-scale process utilizing three staged agitated leaching tanks for reaction residence time followed by disc filtration. Acid leaching of a final titanate side stream achieves the required NPE purge of metals. Potassium remains in the system either as potassium titanate or potassium hydroxide and carbonate. This poses no problem without a Tomlinson recovery boiler in the system.

An additional hydraulic burden is put on the black liquor concentrator system due to the high flow rate of suspended titanate solids to $50 \%$ black liquor. The fact that most of the sulfur portioned to the smelt phase means that less NT3 would be required in the real system compared to what was allowed for in the study. It is not known exactly what the performance and maintenance impact will be with this additional $40 \%$ mass flow load 
increase. The additional suspended solids could enhance the crystallization process and reduce fouling for $80 \%$ solids liquor production by providing sites for crystallization to take place rather than on heat transfer surface areas. On the other hand, the added abrasiveness of the concentrated black liquor may pose a maintenance risk to the process equipment.

Titanate bears no advantage to the mill water balance except when compared to a conventional lime kiln wet scrubber system. In this case there is a 40 to $50 \%$ reduction in water lost to the sewer or atmosphere with the titanate option.

The titanate option economics are very favorable. The titanate recovery system is estimated at about \$32MM with an NPV and IRR, relative to the base case, of \$25.2MM and $23.9 \%$. The situation would improve by using only two leaching stages: NPV increases to approximately $\$ 35 \mathrm{MM}$ and IRR to approximately 35\%. The main issue as of this writing is scale-up from lab results. Pilot plant testing is required to firm up the process scope and capital cost estimate.

The borate case is also attractive, with NPV of \$16MM and very low initial capital cost. The chemistry has also been demonstrated at the mill scale in Tomlinson boilers, and thus is a lower risk. The existence of a functioning caustic plant would favor the borate option.

Using the Larson study as a reference, it was commensurately assumed that a working lime cycle is already in place and the decision to use BLG is being weighed against a new recovery boiler. A cost of a caustic plant is approximately $\$ 35 \mathrm{MM}$, which was not included in the economics. Thus if a greenfield mill or forest products biorefinery is being planned, or if both the boiler and caustic plant are in need of refit at an existing mill, then the titanate option is the better choice.

It should be noted that the reference case selected from the Larson [2] study was based on HTBLG at 35 bar pressure. Our findings indicate that pressures below 5 bar were required to limit the $\mathrm{CO}_{2}$ partial pressure and thus allow the causticizing reactions to proceed. This is simply a technology gap that must be overcome if the planned process requires pressurized syngas (e.g. combine cycle power generation, or Fischer-Tropsh diesel). There are other processes to gasify kraft black liquor, all of which will require some form of causticizing to produce suitable pulping liquors. This study focused only on gasification conditions found in two actively marketed processes of current industry interest. The favorable economics provide incentive to resolve the pressure limitation. 


\section{FUTURE WORK}

A number of key questions arose during this project which were either beyond the scope of the project, or for which resource limitations prevented further investigation. Additional work in the area of in situ causticization for BLG should address one or more of these points:

- The manganates showed great promise by achieving complete conversion of carbonate to hydroxide for the LTBLG case. Manganates failed during the leaching step when they could not be leached back to $\mathrm{Mn}_{3} \mathrm{O}_{4}$. The potassium remained with the solid phase and thus contaminated the manganate. Further work could be done to identify the exact reason for this and possibly modify or add to the leaching procedure to restore the $\mathrm{Mn}_{3} \mathrm{O}_{4}$ for subsequent cycles through the process.

- The titanate solids recovered from leaching of the char should be mixed with black liquor and gasified a second time to determine if the same conversion is achieved as in the first cycle. The complete operational cycle should be verified to confirm that the titanates are not altered in some way that was not characterized in this study.

- The borates should be run at higher doping levels to determine of complete (at least $85 \%$ ) causticization can be achieved for the HTBLG case.

- The pressure limitation on the titanates would rule out their use in pressured BLG. This is due to the high partial pressure of $\mathrm{CO}_{2}$ inhibiting the causticizing reaction at high gasifier pressures. It is worth investigating the possibility of using some sort of multi-stage reactor or arrangement of reactors (e.g. circulating fluid beds) that would achieve the carbon gasification while keeping the $\mathrm{CO}_{2}$ concentration low enough to allow the causticizing reactions to proceed.

\section{ACKNOWLEDGEMENTS}

We gratefully acknowledge sponsorship of this work under U.S. DOE grant \#DE-FC2602-NT41492, and cost sharing support from the Gasification and Biorefinery Development industry consortium at IPST at GA Tech. Also the technical contributions from Andritz Corp and from ITT Goulds for the mill integration study.

We also acknowledge technical contributions to this work and fruitful discussions with Dr. Ingrid Nohlgren of the Energy Technology Center, in Pitea Sweden; and fruitful discussions with Prof. Adriaan van Heiningen, (Chemical Engineering Dept., University of Maine, USA). 


\section{REFERENCES}

[1] Tucker, P., "Closing in on a Step Change in Power Generation from Self-Generated Fuels - The Pathway Parts 1 and 2", DOE Energy Summit white paper, Peachtree City, GA May, 2001, TAPPI Solutions, Feb-March, 2002

[2] NOHLGREN, I., "Recovery of Kraft Black Liquor with Direct Causticization using Titanates", Ph.D. Thesis, Luleå University of Technology, Luleå, Sweden (2002).

[3] Nohlgren, I., Sricharoenchaikul, V., Sinquefield, S., Frederick, W., Theliander, H. "Black Liquor Gasification with Direct Causticization using Titanates in a Pressurized Entrained Flow Reactor, Part 1: Kinetics of the Causticization Reaction", J. Pulp Pap. Sci 29(4):107-113 (2003).

[4] Eames, D.E., Empie, H.J., "Direct Causticizing of Sodium Carbonate with Manganese Oxide", IPST Technical Paper Series \#889, Institute of Paper Science and Technology, Atlanta, GA, 2001

[5] Eames, D.E., Empie, H.J., "Direct Causticizing of Sodium Carbonate Using Manganese Oxide", Proceedings of the International Chemical Recovery Conference, Whistler, B.C., June 11-14, 2001

[6] Tran, H.N., Mao, T., Lesmana, N., Kochesfahani, S.H., Bair, C.M., "Effects of Partial Borate Autocausticizing on Kraft Recovery Operations", International Chemical Recovery Conference, Whistler, B.C., June, 2001

[7] Mark, J., Hoddenbagh, A., Wilfing, K., Miller, K., Hardman, D., Tran, H.N., Bair, C., "Borate Autocausticizing- A Cost Effective Technology", International Chemical Recovery Conference, Whistler, B.C., June, 2001

[8] Hupa, M., Forssen, M., Backman, R., Stubs, A., Bolton, R., "Fireside Behavior of Black Liquors Containing Boron", International Chemical Recovery Conference, Whistler, B.C., June, 2001

[9] Sinquefield, S.A., Unpublished data

[10] Larson, E.D., et.al., "A Cost-Benefit assessment of Black Liquor Gasification/Combined Cycle Technology Integrated into a Kraft Pulp Mill", International Chemical Recovery Conference, Tampa, June 1-4, 1998

[11] Zou, X., "Recovery of Kraft Black Liquor Including Direct Causticization", Ph. D. Thesis, McGill University, Montreal, QC, Canada (1991).

[12] Nohlgren, I., Theliander, H., Zhuang, Q. and Van Heiningen, A.R.P, "Model Study of the Direct Causticization Reaction Between Sodium Trititanate and Sodium Carbonate", CJChE 78(3): 529-539 (2000).

[13] Palm, M. and Theliander, H., "Kinetic Study on the Direct Causticization reaction Including Titanates and Titanium Dioxide", Chem. Eng. Journ. 68: 87-94 (1997).

[14] Zhuang, Q., Gai, H., van Heiningen, A.R.P., Nohlgren, I. and Theliander, H., "Direct Causticization of Kraft Black Liquor with Recycled Sodium Titanate", 1998 Int. Chem. Recov. Conf, Tampa, Florida, USA, June 1-4, 831-839 (1998).

[15] Zeng, L., "Kraft Black Liquor Gasification and Direct Causticization in a Fluidized Bed", Ph.D. Thesis, University of New Brunswick, Fredericton, N.B., CA (1997). 
[16] RICHARDS, T., "Recovery of Kraft Black Liquor - Alternative Processes and System Analysis", Ph.D. Thesis, Chalmers University of Technology, Gothenburg, Sweden (2001).

[17] Green, R.P., Hough, G., "Chemical Recovery in the Alkaline Pulping Process", 3 rd Ed, TAPPI Press, 1992

[18] Nohlgren, I., Sricharoenchaikul, V., Sinquefield, S, Frederick, W.J., Theliander, H., "Black Liquor Gasification with Direct Causticization using Titanates in a Pressurized Entrained Flow Reactor, Part 1: Kinetics of the Causticization Reaction", Journal of Pulp and Paper Science, 29(4): 107-113 (2003)

[19] Sinquefield, S., Sricharoenchaikul, V., Frederick, W.J., Dayton, D., Ratcliff, M., French, R., Carpenter, D., and Lewnard, J., "Black Liquor Gasification I: The Impact of Pressure on $\mathrm{C}-\mathrm{H}-\mathrm{O}-\mathrm{S}$ gas Speciation and Tar Components During Pyrolysis", International Chemical Recovery Conference, Whistler BC, June 11-14, 2001

[20] Levenspiel, O., The Chemical Reactor Omnibook, OSU Press

[21] T.Milman and R. Bouaziz, Ann. Chim. (paris), 3[4], 313 (1968)

[22] Eriksson, G. and Pelton, A. D., "Critical Evaluation and Optimization of the Thermodynamic properties and Phase Diagrams of the $\mathrm{MnO}-\mathrm{TiO}_{2}, \mathrm{MgO}-\mathrm{TiO}_{2}$, FeO-TiO $, \mathrm{Ti}_{2} \mathrm{O}_{3}-\mathrm{TiO}_{2}, \mathrm{Na}_{2} \mathrm{O}-\mathrm{TiO}_{2}$, and $\mathrm{K}_{2} \mathrm{O}-\mathrm{TiO}_{2}$ Systems, Metall. Trans. B, Vol. 24B, p. 795-805 (1993).

[23] Zou, X., G.J. Kubes, M.M. Avedesian and van Heiningen, A.R.P., "Autocausticizing of Kraft Black Liquor: Process implications based on Chemical Equilibrium Calculations", 1990 Pulping Conference, p. 897-903 (1990).

[24] Backman, R. and Salmenoja, K., "Equilibrium behaviour of sodium, sulfur and chlorine in pressurized black liquor gasification with addition of titanium dioxide", Paperi Ja Puu - Paper and Timber, 76 (5), p.320-325 (1994).

[25] Richards, T., Nohlgren, I., Warnqvist, B. and Theliander, H., "Mass and Energy Balances for a Conventional Recovery Cycle and for a Recovery Cycle using Borates of Titanates", Nordic Pulp and Paper Research Journal, Vol.17(3), p. 213221 (2002).

[26] Warnqvist, B., Delin, L., Theliander, H. and Nohlgren, I., "Techno-economical Evaluation of Black Liquor Gasification Processes", 2001 Int. Chem. Recov. Con.f, Whistler, BC, Canada, June 10-14 (2001).

[27] Wagman, et.al. "NBS Tables of Chemical Thermodynamic Properties", Journal of Phys and Chem Ref Data, 11(2) 1982

[28] Larson, E., Consonni, S. and Katofsky, R., "A Cost-Benefit Assessment of Biomass Gasification Power Generation in the Pulp and Paper Industry', Princeton University, Final Report (Oct, 2003).

[29] Budney, J.L., "Method of Recovering Caustic Soda from Spent Pulping Liquor", Canadian Patent 1,283,256 (1991). 


\section{ABBREVIATIONS}

PEFR: Pressurized laminar Entrained Flow Reactor

LEFR: Laminar Entrained Flow Reactor

BLG: Black Liquor Gasification

HTBLG: High Temperature BLG

LTBLG: Low Temperature BLG

BLGCC: Black Liquor Gasification with Combined Cycle power generation

BL: Black Liquor

XRD: X-Ray Diffraction

SEM: Scanning Electron Microscopy

\section{END OF MAIN BODY OF REPORT APPENDIX A FOLLOWS}




\section{Project}

DE-FC26-02NT41492

\section{APPENDIX A}

\section{EXPERIMENTAL DATA}




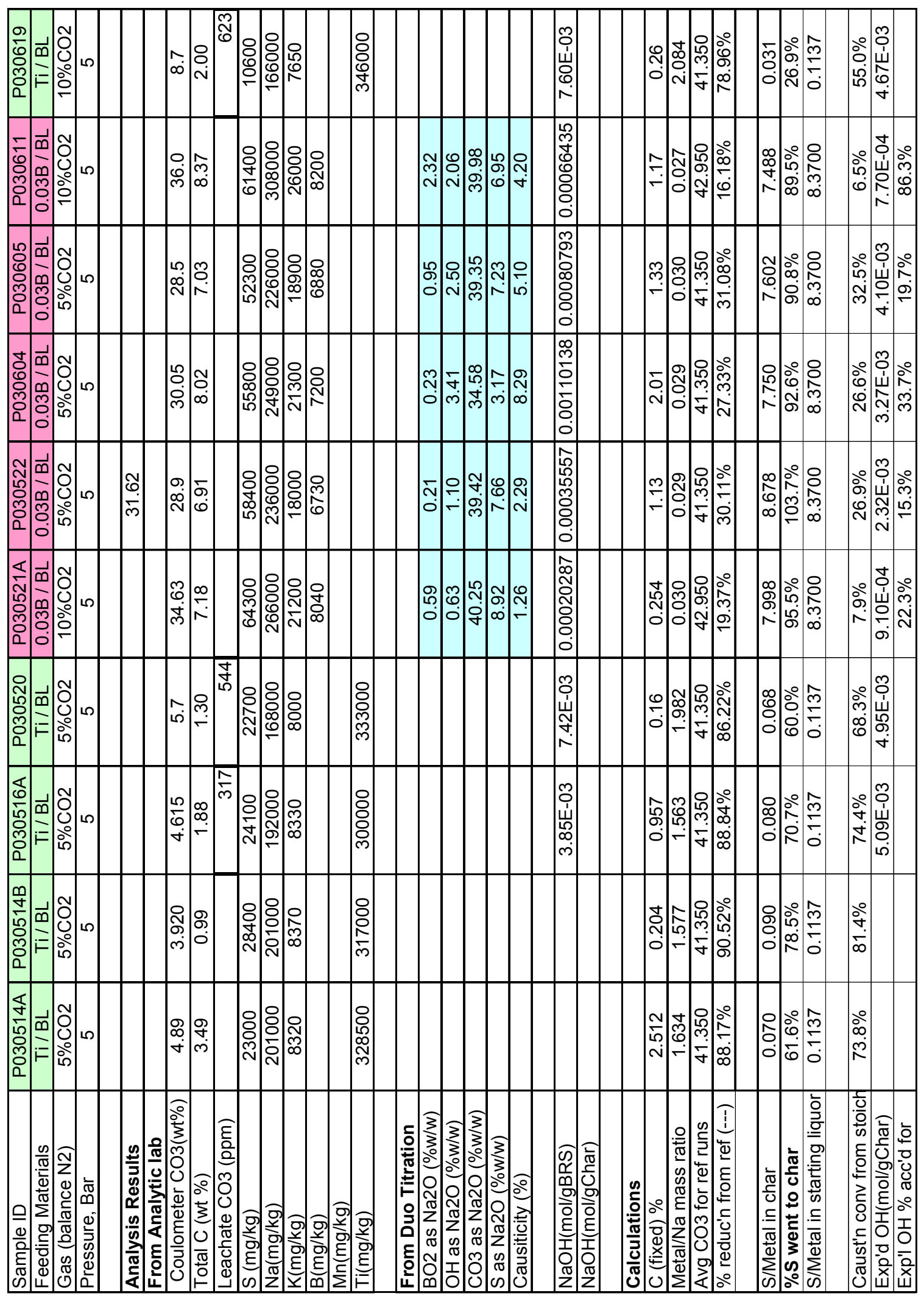




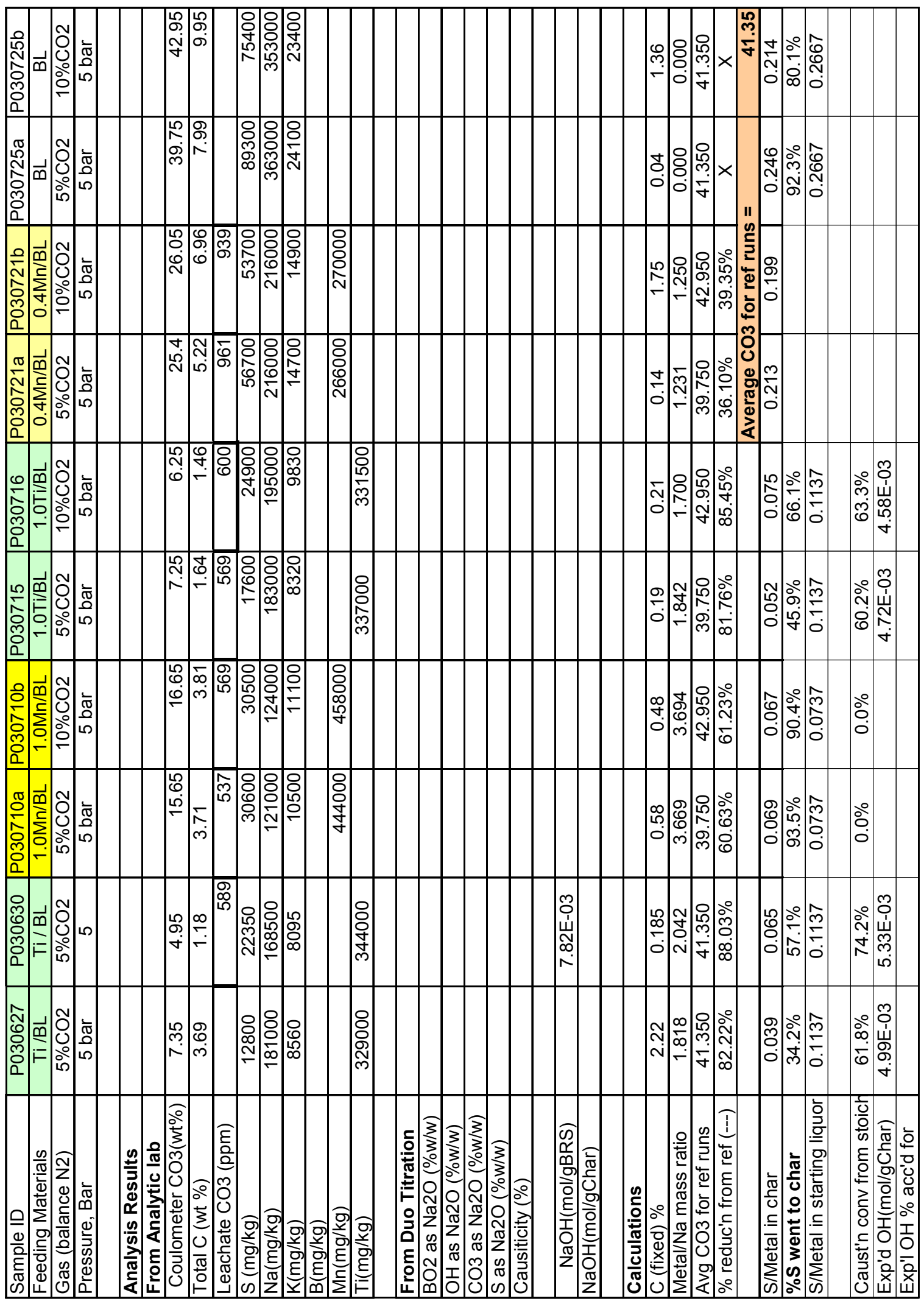




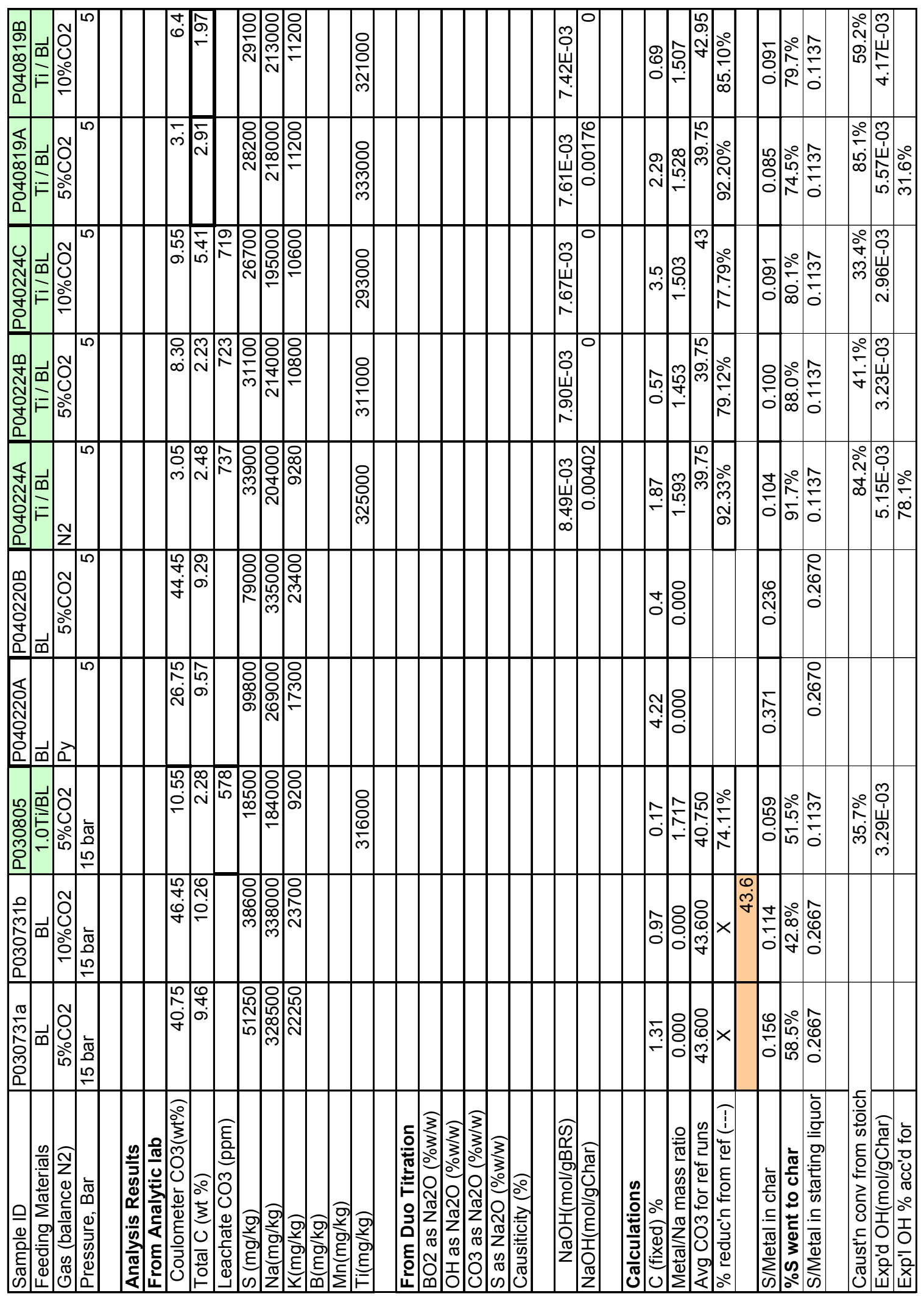




\begin{tabular}{|c|c|c|c|c|c|c|c|c|c|c|c|c|c|c|c|c|c|c|c|c|c|c|c|c|c|c|c|c|c|c|}
\hline 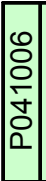 & 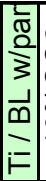 & 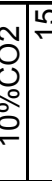 & 5 & & $\mid \begin{array}{l}5 \\
8 \\
2\end{array}$ & $\begin{array}{l}c \\
\dot{j} \\
\end{array}$ & & 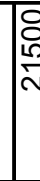 & $\begin{array}{l} \\
\vdots \\
\frac{0}{2} \\
\frac{0}{2}\end{array}$ & & & ০্টি & & & & & & & 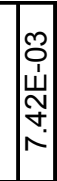 & 0 & & مִ & 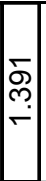 & 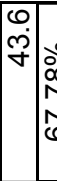 & & $\left|\begin{array}{c}N \\
\hat{o} \\
0 \\
0\end{array}\right|$ & $\mid \begin{array}{c}0 \\
\\
\\
0 \\
0\end{array}$ & & $\begin{array}{c}\stackrel{\circ}{ } \\
\stackrel{+}{ }\end{array}$ & $\begin{array}{l}0 \\
0 \\
\dot{u} \\
0 \\
0 \\
\\
\end{array}$ \\
\hline 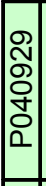 & \begin{tabular}{|l|}
$\frac{2}{\pi}$ \\
$\frac{2}{3}$ \\
$\bar{m}$ \\
\\
$=$ \\
\end{tabular} & 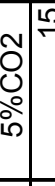 & & & $\widehat{\sigma}$ & $\stackrel{\substack{n \\
m}}{m}$ & & হ্তি & 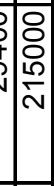 & 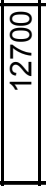 & & 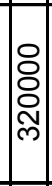 & & & & & & & 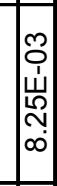 & $\mid \begin{array}{c}\bar{N} \\
\infty \\
0 \\
0 \\
0 \\
0\end{array}$ & & $\stackrel{r}{r}$ & $\mid$\begin{tabular}{c}
$\infty$ \\
$\infty$ \\
\multirow{\sigma}{*}{} \\
-
\end{tabular} & 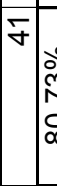 & 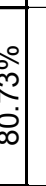 & $\mid \begin{array}{l}\text { જे } \\
\circ \\
0\end{array}$ & $\left(\begin{array}{c}0 \\
\infty \\
\infty \\
\infty \\
\infty \\
\infty \\
c\end{array}\right.$ & & م̊̊ & 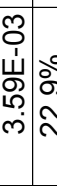 \\
\hline 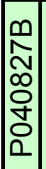 & $\frac{\vec{m}}{\bar{m}}$ & 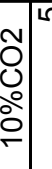 & $\sqrt{3}$ & & $\infty$ & of & & 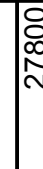 & v| & \begin{tabular}{|l|} 
\\
\end{tabular} & & 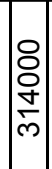 & & & & & & & 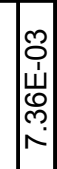 & $\begin{array}{l}\infty \\
\frac{1}{2} \\
\overline{8} \\
0 \\
0\end{array}$ & & $\mid \begin{array}{l}\mathscr{C} \\
\stackrel{0}{0}\end{array}$ & 足 & 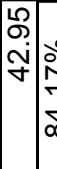 & 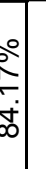 & $\left|\begin{array}{l}\mathscr{\infty} \\
\infty \\
0 \\
0\end{array}\right|$ & ça & & $\begin{array}{l}0 \\
0 \\
0 \\
6 \\
10 \\
\end{array}$ & 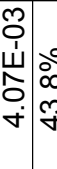 \\
\hline 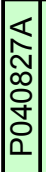 & $\frac{\vec{m}}{\sim}=$ & 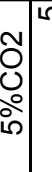 & & & $\bar{m}$ & & & 유 & †े & \begin{tabular}{|} 
잉 \\
$\frac{\mathrm{O}}{\mp}$
\end{tabular} & & 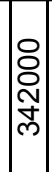 & & & & & & & $\begin{array}{c}\infty \\
0 \\
0 \\
w \\
\stackrel{N}{N} \\
\infty \\
\infty\end{array}$ & \begin{tabular}{|c|}
0 \\
$\infty$ \\
- \\
0 \\
0 \\
0
\end{tabular} & & مَ & 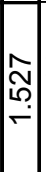 & 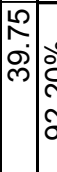 & 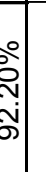 & $\mid \begin{array}{l}\mathscr{\infty} \\
\infty \\
0 \\
0 \\
0\end{array}$ & ב̀ & & $\begin{array}{l}\text { ○े } \\
\text { N } \\
\infty \\
\infty\end{array}$ & 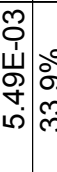 \\
\hline 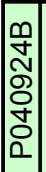 & 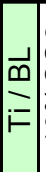 & 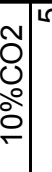 & & & $\mid \begin{array}{l}10 \\
15 \\
15\end{array}$ & & & 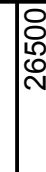 & 可 & $\begin{array}{l} \\
\\
0 \\
\circ \\
\circ \\
\end{array}$ & & $\mid \begin{array}{l}8 \\
\mathbb{D} \\
\infty \\
\mathbb{N} \\
\mathrm{m}\end{array}$ & & & & & & & 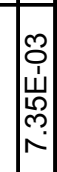 & 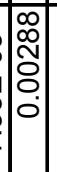 & & $\begin{array}{l}\tilde{N} \\
\tilde{O} \\
0\end{array}$ & $\mid \begin{array}{c}\tilde{N} \\
0 \\
0 \\
-\end{array}$ & 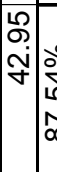 & $\begin{array}{l} \\
0 \\
0 \\
0 \\
0 \\
\infty \\
\infty \\
\end{array}$ & $\left|\begin{array}{l}\bar{\infty} \\
0 \\
0\end{array}\right|$ & $\frac{\substack{c\\
}}{2}$ & & $\begin{array}{l} \\
0 \\
8 \\
8 \\
\end{array}$ & 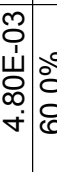 \\
\hline 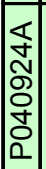 & 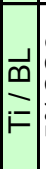 & \begin{tabular}{l|l}
\multirow{2}{*}{} & \multicolumn{1}{|r}{} \\
0 \\
0 \\
0 \\
0 \\
0
\end{tabular} & & & $\infty$ & & & $\begin{array}{l}\text { 尺 } \\
\text { N } \\
\text { N }\end{array}$ & 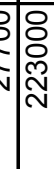 & \begin{tabular}{|l} 
\\
응 \\
ㄱ.
\end{tabular} & & $\mid \begin{array}{l}\text { Oి } \\
\text { స్స్ } \\
\text { లె }\end{array}$ & & & & & & & 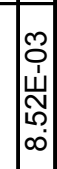 & 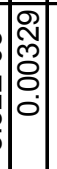 & & $\stackrel{\nabla}{-}$ & 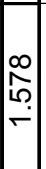 & 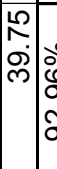 & 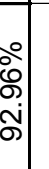 & 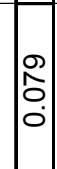 & 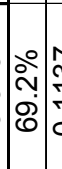 & & $\begin{array}{c}0 \\
\infty \\
\infty \\
\infty \\
\infty\end{array}$ & 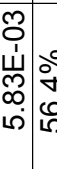 \\
\hline 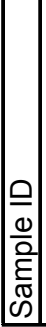 & 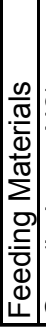 & 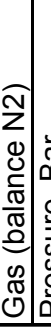 & 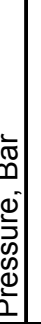 & 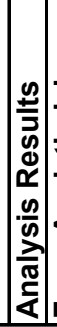 & 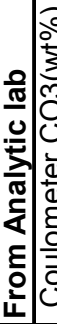 & 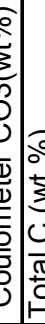 & 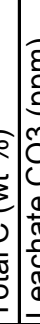 & 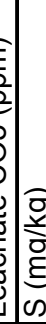 & 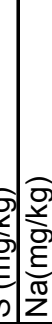 & 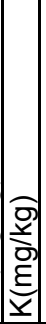 & 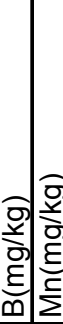 & : & 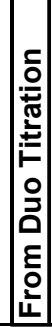 & 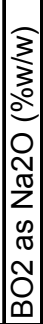 & 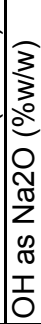 & 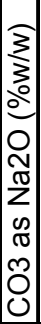 & 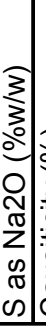 & 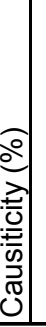 & 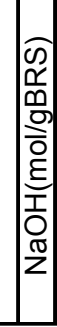 & 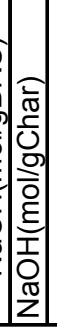 & 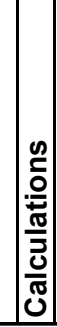 & 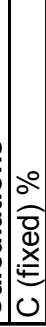 & 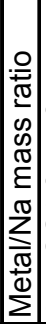 & 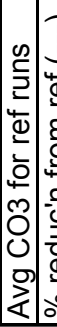 & 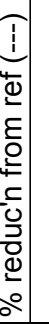 & 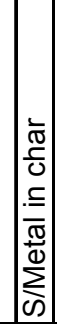 & 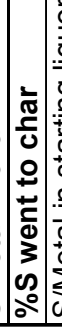 & $\begin{array}{l}\frac{\pi}{\omega} \\
. \subseteq \\
. \bar{\pi} \\
\frac{\pi}{0} \\
\sum_{\omega}^{\infty}\end{array}$ & 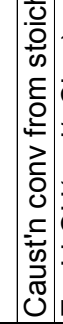 & 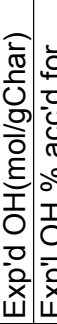 \\
\hline
\end{tabular}




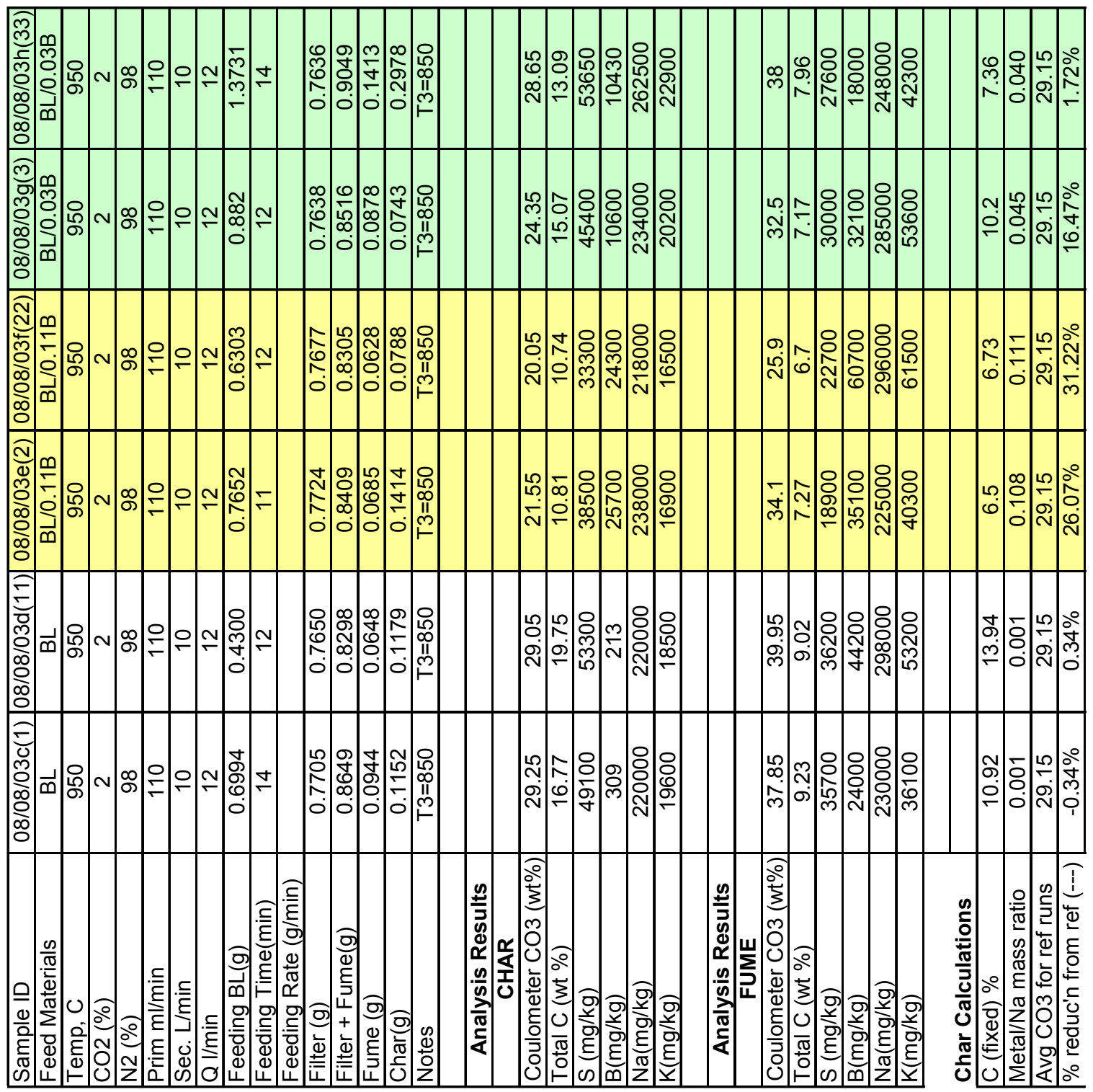




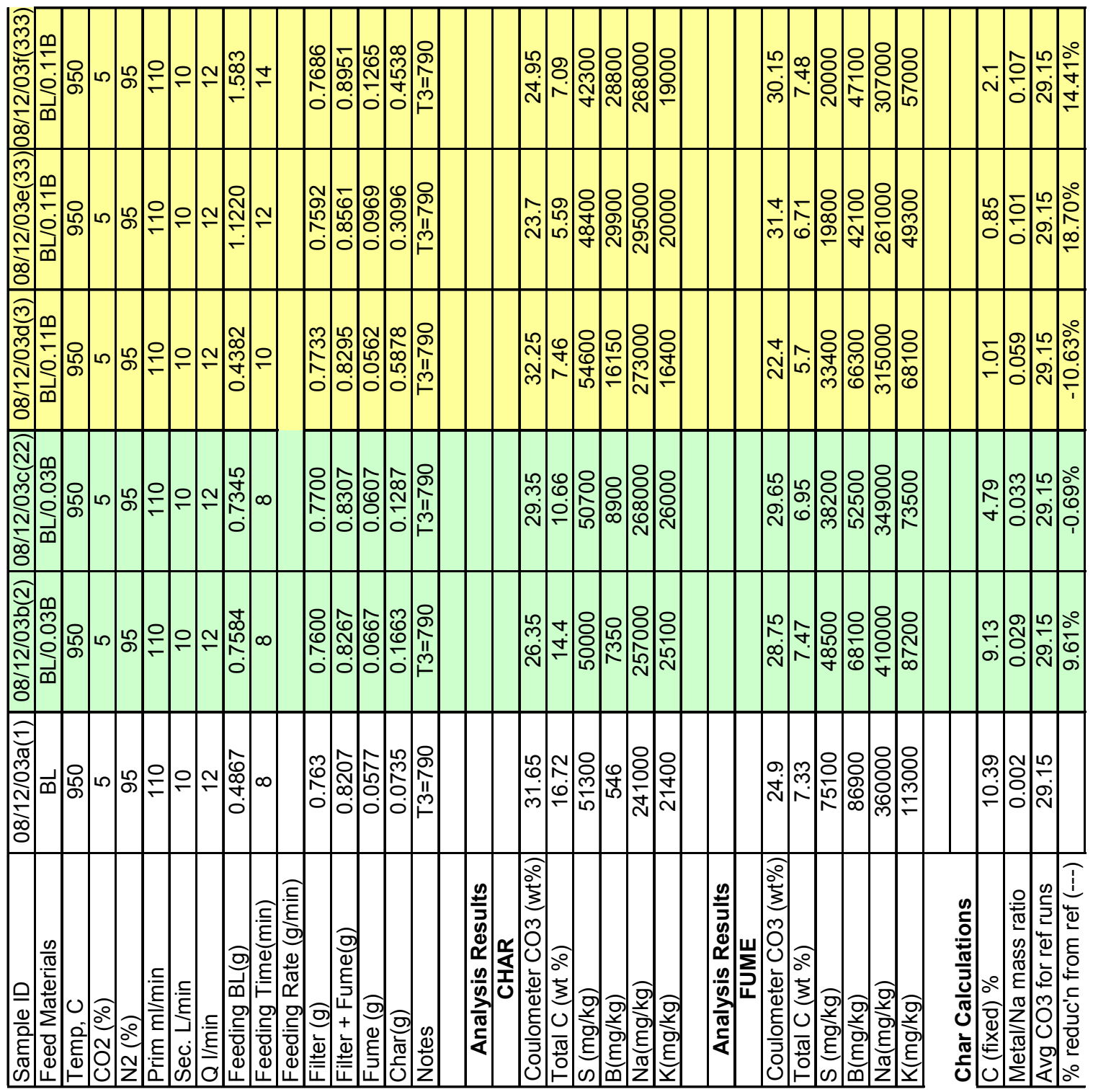




\begin{tabular}{|c|c|c|c|c|c|c|c|c|c|c|c|c|c|c|c|c|c|c|c|c|}
\hline 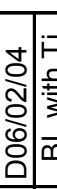 & & & 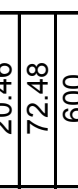 & & & 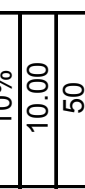 & & & 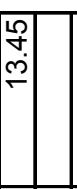 & 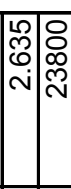 & 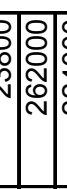 & 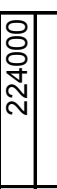 & 임 & & 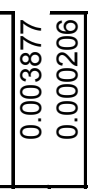 & - & & 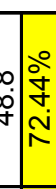 & 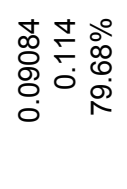 & 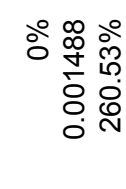 \\
\hline 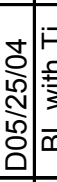 & & & 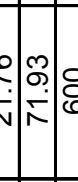 & & & 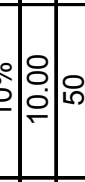 & & & \begin{tabular}{|l|} 
\\
$\dot{x}$ \\
$\dot{T}$
\end{tabular} & 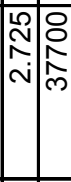 & 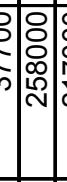 & & 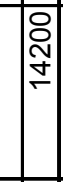 & & 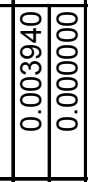 & זי. & & ơ & 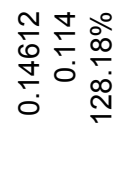 & 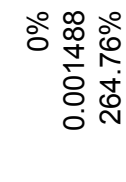 \\
\hline 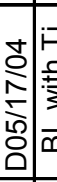 & & 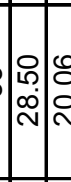 & & bे & & \begin{tabular}{c|c|c|c|c|}
8 \\
\hdashline
\end{tabular} & & & 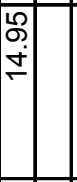 & 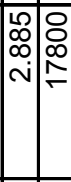 & •. & 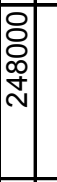 & 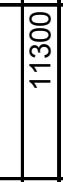 & & 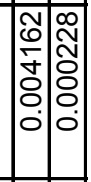 & : & & 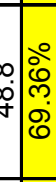 & $\begin{array}{l}\hat{0} \\
\& \\
0 \\
0 \\
0 \\
0\end{array}$ & 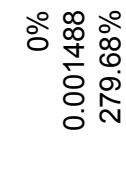 \\
\hline 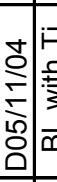 & & 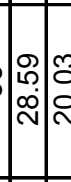 & \begin{tabular}{c|c}
3 \\
$: 3$
\end{tabular} & bे & & : & & & 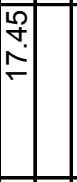 & $\begin{array}{ll}\infty & 0 \\
0 & 0 \\
0 & 0 \\
0 & 0 \\
0\end{array}$ & ‘ी & | & 赵 & & 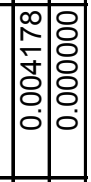 & & & 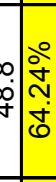 & 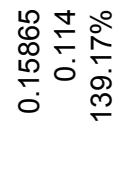 & 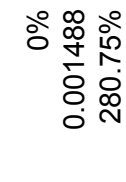 \\
\hline 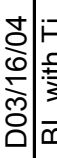 & & 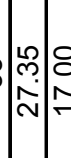 & 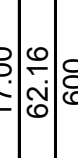 & b) & & م & & & \begin{tabular}{|l|l|} 
& \\
\\
$\infty$
\end{tabular} & 守唐 & ơ & | & $\mid \begin{array}{l}8 \\
\vdots \\
\vdots \\
0 \\
\end{array}$ & & 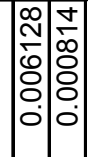 & 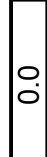 & 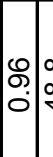 & 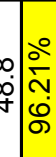 & 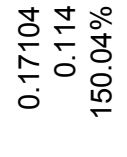 & 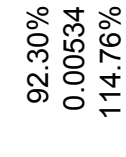 \\
\hline 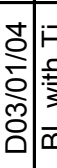 & 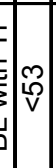 & 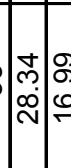 & 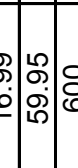 & b & & 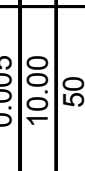 & & & 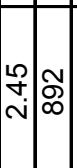 & 시류 & งิ & $\begin{array}{l}\text { D } \\
\text {. } \\
\\
\text { N }\end{array}$ & 总 & & 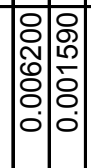 & $\begin{array}{l}0 \\
0\end{array}$ & & 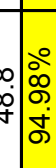 & 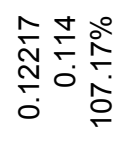 & 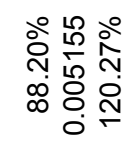 \\
\hline 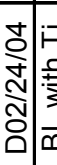 & & 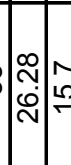 & 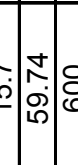 & bे & & 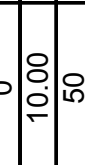 & & & 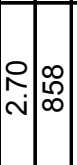 & @) & งे & $\begin{array}{l}8 \\
\text { a } \\
\vdots \\
\text { Na }\end{array}$ & $\mid$ & & 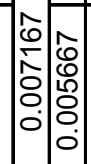 & षे. & 10 & 字 & 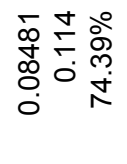 & 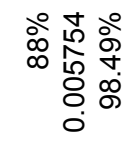 \\
\hline 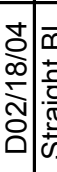 & & $\mid$\begin{tabular}{c|c}
$\stackrel{m}{\infty}$ \\
$\stackrel{\infty}{\infty}$ & $\infty$ \\
$\infty$
\end{tabular} & 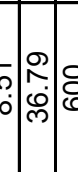 & b) & & \begin{tabular}{l|l} 
& 0 \\
\\
$\circ$
\end{tabular} & & & $\mid \begin{array}{l}\infty \\
\infty \\
\infty \\
+\end{array}$ & ల্ণ & & $\begin{array}{l}\text { D. } \\
\frac{0}{\hat{m}} \\
m\end{array}$ & 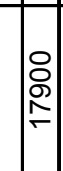 & & & & & 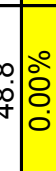 & 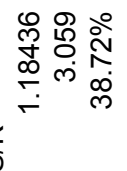 & \\
\hline 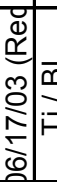 & & & & b) & & م & & & $\nabla$ & - & م્ & 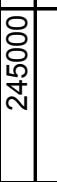 & \begin{tabular}{|l|} 
\\
0 \\
0 \\
\hdashline
\end{tabular} & & 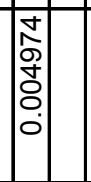 & & $F$ & 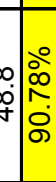 & 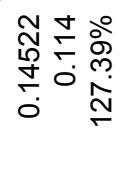 & 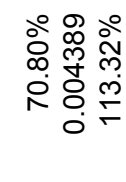 \\
\hline 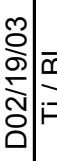 & & $\mid$\begin{tabular}{l|l}
0 \\
\hdashline
\end{tabular} & 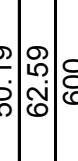 & b. & in & \begin{tabular}{l|l} 
\\
\\
0
\end{tabular} & & & 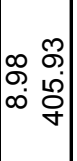 & $\mid$\begin{tabular}{l}
0 \\
0 \\
0 \\
\hdashline \\
-
\end{tabular} & $\begin{array}{l}8 \\
0 \\
0 \\
0 \\
+ \\
\end{array}$ & స్టి & & & $\left|\begin{array}{l}8 \\
8 \\
0 \\
0 \\
0 \\
0 \\
0\end{array}\right|$ & & 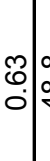 & 守 & $\underset{⿱ 亠}{\check{D}}$ & \\
\hline 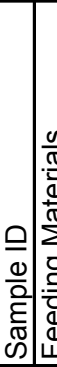 & 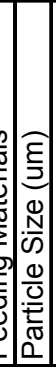 & 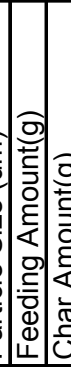 & 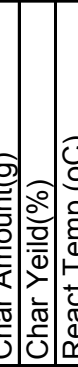 & 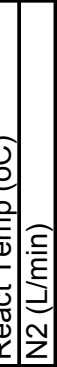 & 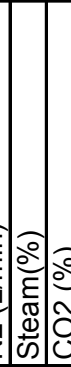 & 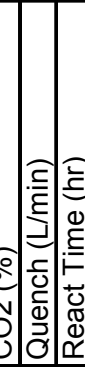 & 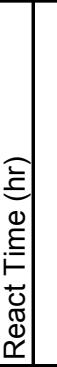 & 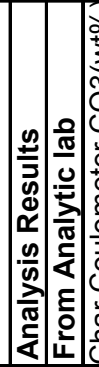 & 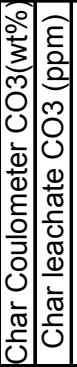 & 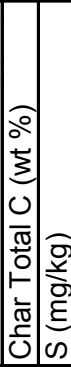 & :00 & 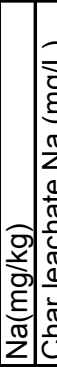 & 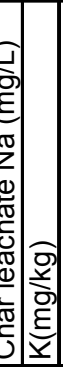 & & 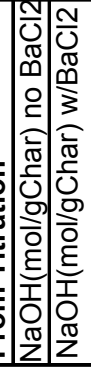 & & & 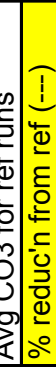 & 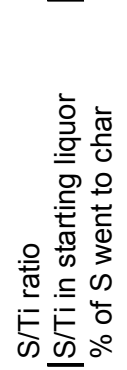 & 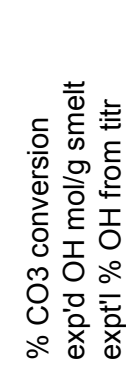 \\
\hline
\end{tabular}




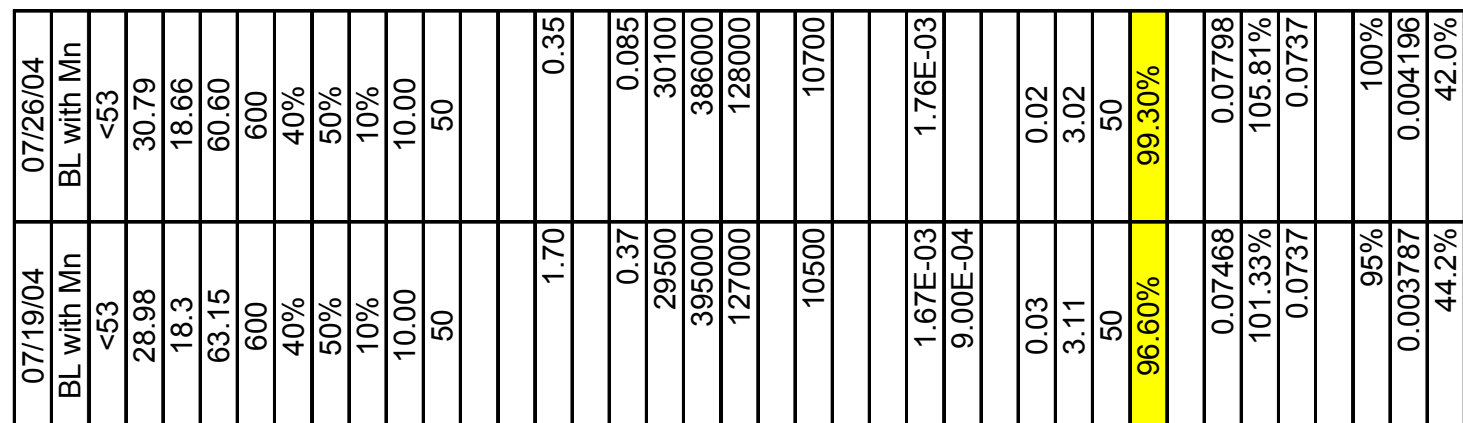

\&

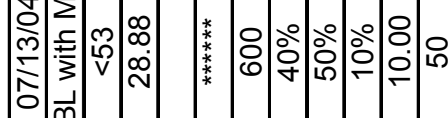

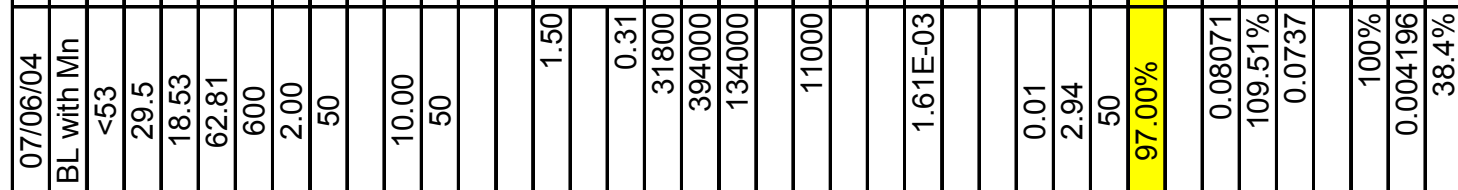

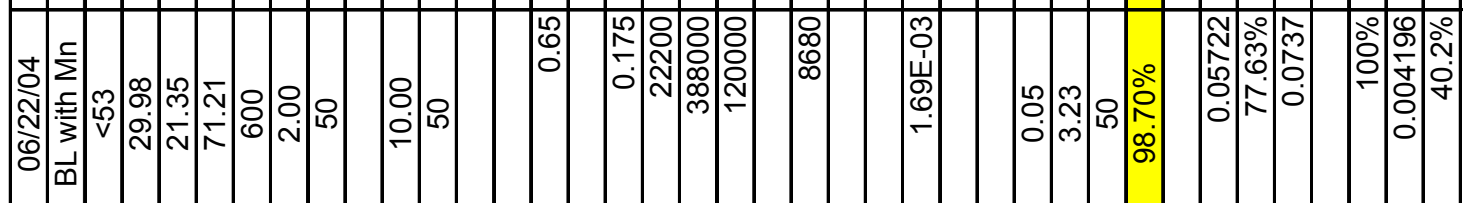

\section{雨}

\%)

됭

잉ำ

웅

岺

- 0.1 :

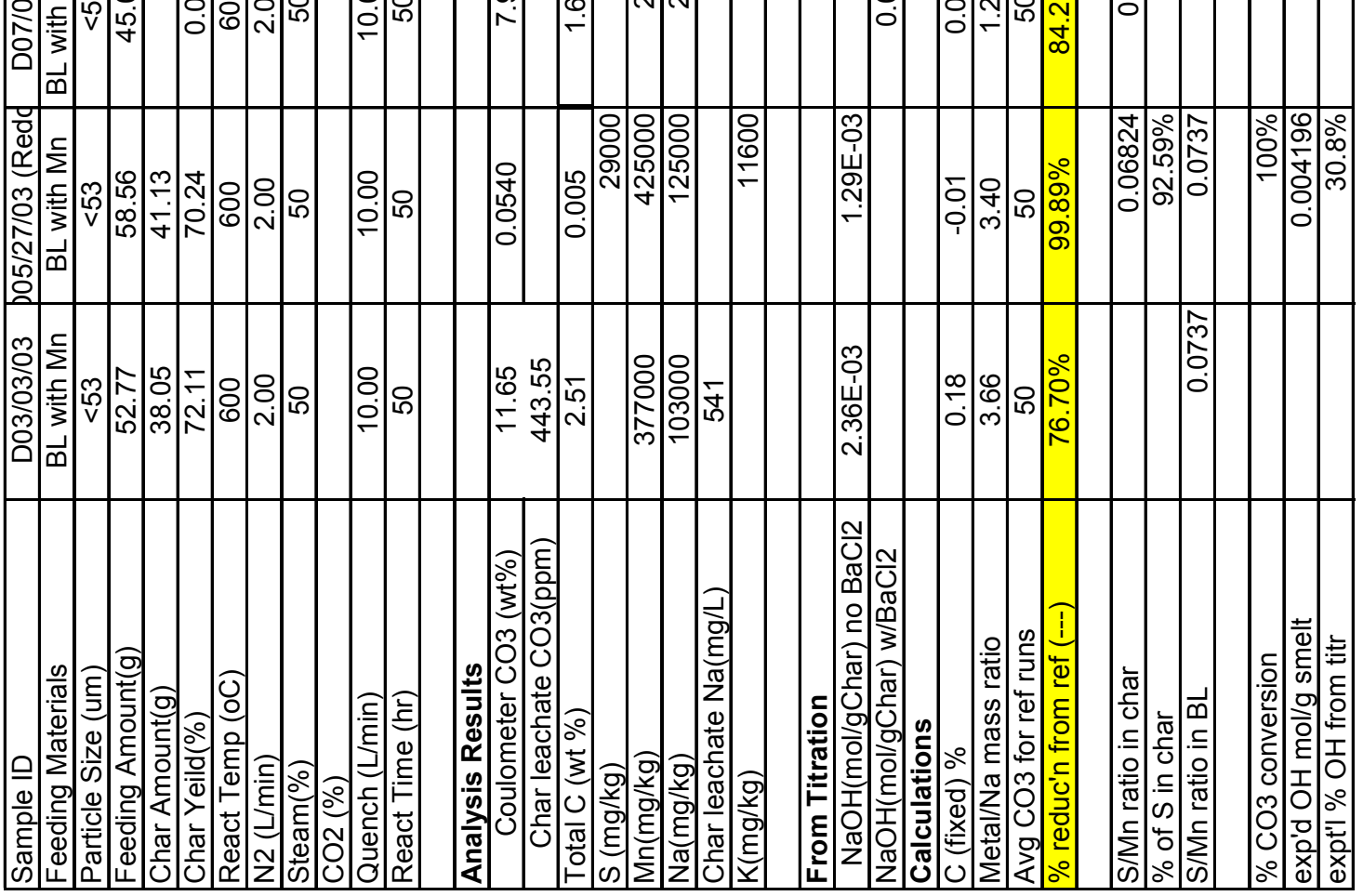




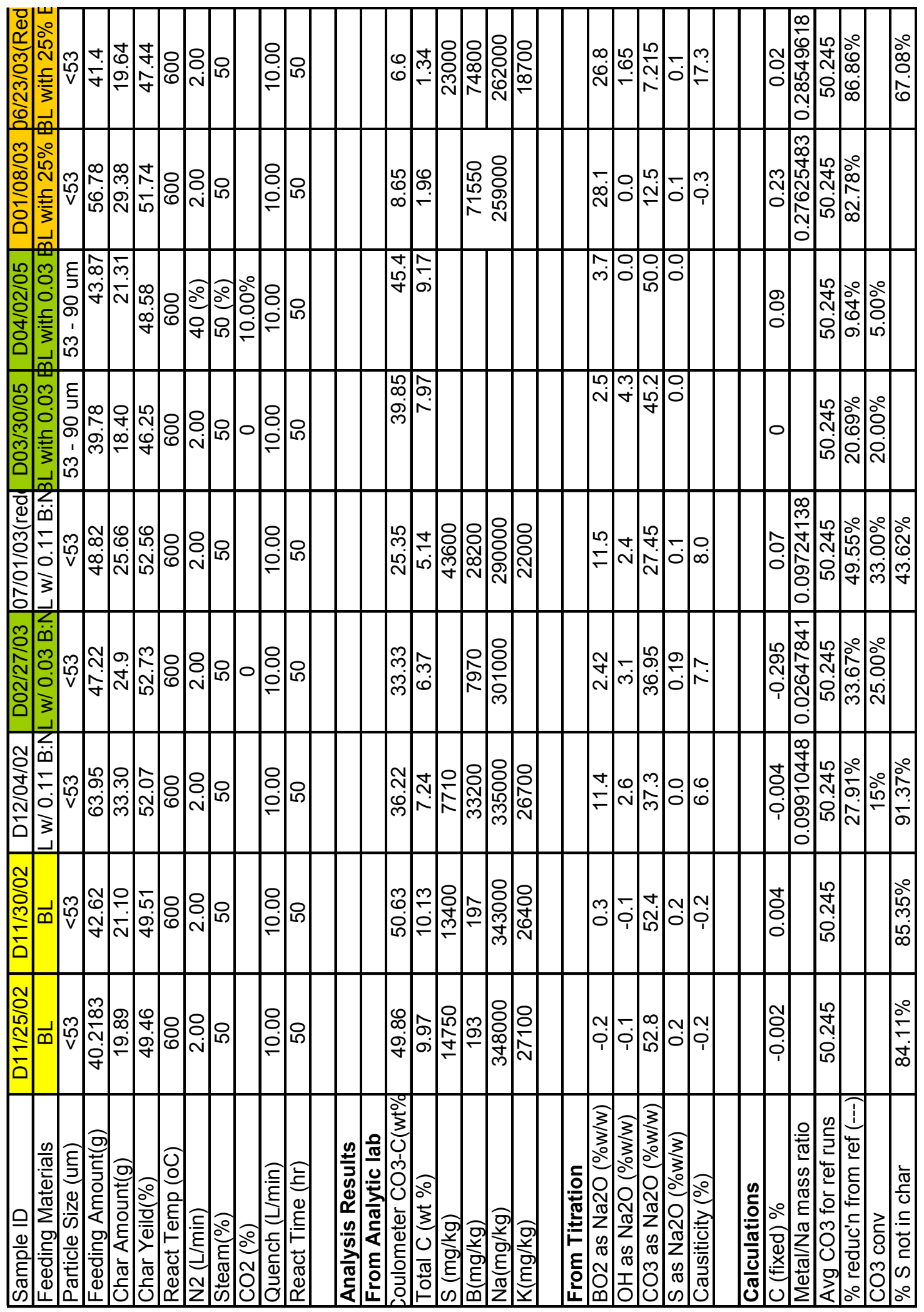


(Ti leaching data)

\begin{tabular}{|c|c|c|c|c|c|c|}
\hline Sample & Leachate Name & Leaching Time & Sample Wt. & Empty Funnel & Funnel+Residue & Residue \\
\hline ID & & $(\min )$ & (g) & (g) & (g) & (g) \\
\hline $\mathrm{D} 02 / 24 / 04$ & 06/28/05 (1st) & 1st 90 min & 2.9994 & 60.5835 & & \\
\hline D02/24/04 & $06 / 28 / 05$ (2st) & 2nd $90 \mathrm{~min}$ & & & & \\
\hline D02/24/04 & $06 / 28 / 05$ (2st) & 2nd $90 \mathrm{~min}$ & & & & \\
\hline D02/24/04 & $06 / 28 / 05$ (3st) & $3 \mathrm{rd} 90 \mathrm{~min}$ & & & 62.3682 & 1.7847 \\
\hline D02/24/04 & $07 / 05 / 05$ (1st) & 1 st 90 min & 5.9994 & $61.5384(\# 3)$ & & \\
\hline D02/24/04 & $07 / 07 / 05(2 \mathrm{st})$ & $2 \mathrm{st} 90 \mathrm{~min}$ & & & & \\
\hline $\mathrm{D} 02 / 24 / 04$ & $07 / 08 / 05$ (3st) & 3rd $90 \mathrm{~min}$ & & & 65.2425 & 3.7041 \\
\hline D03/01/04 & $07 / 06 / 05$ (1st) & $1 \mathrm{st} 90 \mathrm{~min}$ & 6.0001 & 61.1619 (\#S4) & 66.2138 & 5.0519 \\
\hline & & & & & & \\
\hline & & & & & & \\
\hline P050603 & $7 / 13 / 2005$ & $1 \mathrm{st} 90 \mathrm{~min}$ & 5.9987 & $60.9718(\mathrm{~F} 2)$ & 65.5840 & 4.6122 \\
\hline P050603 & $7 / 13 / 2005(2)$ & $1 \mathrm{st} 90 \mathrm{~min}$ & 6.0058 & $60.6015(4)$ & 65.3008(black) & 4.6993 \\
\hline P050621(very loose) & $7 / 14 / 2005$ & $1 \mathrm{st} 90 \mathrm{~min}$ & 6.0004 & 61.4731(\#3) & 283(black) split out s & $2.2552^{*}$ \\
\hline P050621(very loose) & $7 / 14 / 2005(2)$ & $1 \mathrm{st} 90 \mathrm{~min}$ & 6.0006 & 61.3489 (\#S4) & & \\
\hline & & & & & & \\
\hline D02/19/03 & $7 / 18 / 2005^{\star *}$ & $1 \mathrm{st} 90 \mathrm{~min}$ & 6.0006 & 71.3095(new) & 74.7854 & 3.4759 \\
\hline D02/19/03 & $7 / 18 / 2005(2)^{* *}$ & $1 \mathrm{st} 90 \mathrm{~min}$ & 6.0005 & $62.1039(\mathrm{~S} 4)$ & 65.5746 & 304707 \\
\hline $\mathrm{D} 02 / 19 / 03$ & $7 / 26 / 2005$ & 1 ct $90 \mathrm{~min}$ & 59997 & $616290(+3)$ & & \\
\hline $\mathrm{D} 02 / 19 / 03$ & $7 / 26 / 2005(2)$ & $1 \mathrm{st} 90 \mathrm{~min}$ & 6.0030 & $\frac{61.029(A+3)}{60.6083(\# 4)}$ & & \\
\hline $\mathrm{D} 02 / 19 / 03$ & $7 / 26 / 2005(3)$ & $1 \mathrm{st} 90 \mathrm{~min}$ & 5.9990 & $60.9828(F 2)$ & & \\
\hline D02/19/03 & $7 / 27 / 2005$ & $1 \mathrm{st} 90 \mathrm{~min}$ & 5.9991 & 61.2333(\#2) & & \\
\hline $\mathrm{D} 06 / 17 / 03$ & $7 / 27 / 2005(2)$ & $1 \mathrm{st} 90 \mathrm{~min}$ & 6.0005 & 71.1018(new) & & \\
\hline & & & & & & \\
\hline $7 / 27 / 2005$ & $7 / 28 / 2005$ & 2nd $90 \mathrm{~min}$ & & & & \\
\hline $7 / 27 / 2005(2)$ & $7 / 28 / 2005(2)$ & 2nd $90 \mathrm{~min}$ & & & & \\
\hline \multicolumn{7}{|l|}{${ }^{*}$ split a lot of solids out. } \\
\hline \multicolumn{7}{|c|}{ ** Use vacuum pump. Vacuum trap is very cold. } \\
\hline \multicolumn{7}{|c|}{ *** Leaching solution pink will come back a little bit $(0.058-0.094 \mathrm{ml})$ after it reaches to end points for PEFR runs. } \\
\hline \multicolumn{7}{|l|}{ Reference: } \\
\hline $\mathrm{D} 02 / 24 / 04$ & & & 0.9998 & & & \\
\hline \multicolumn{7}{|l|}{ D02/19/03 } \\
\hline \multicolumn{7}{|l|}{$\mathrm{D} 06 / 17 / 03$} \\
\hline \multicolumn{7}{|l|}{ Procedure: } \\
\hline \multicolumn{7}{|c|}{ (1). 1st leaching: Weight about 3 grams char and add $45 \mathrm{ml} \mathrm{DDH2O}$, leaching $90 \mathrm{~min}$ at $100 \mathrm{C}$. } \\
\hline \multirow{2}{*}{\multicolumn{7}{|c|}{\begin{tabular}{|c|c|c|} 
Filter it and transfer leachate to $50 \mathrm{ml}$ volumetric bottle. & & \\
(2) 2 nd leaching: & & \\
\end{tabular}}} \\
\hline \multirow{2}{*}{\multicolumn{7}{|c|}{$\begin{array}{c}\text { (2). 2nd leaching: Dry about 30min leaching cake which is gotten from Procedure (1) with funnel in oven. } \\
\text { Transfer residual to } 3 \text { neck bottle and add } 45 \mathrm{ml} \mathrm{DDH2O} \text {, leaching } 90 \mathrm{~min} \text { at } 100 \mathrm{C} \text {. }\end{array}$}} \\
\hline & & & & & & \\
\hline \multicolumn{7}{|c|}{ Filter it and transfer leachate to $50 \mathrm{ml}$ volumetric bottle. } \\
\hline \multicolumn{7}{|c|}{ (3). 3nd leaching: Dry about 30min leaching cake which is gotten from Procedure (2) with funnel in oven. } \\
\hline \multicolumn{7}{|c|}{ Transfer residual to 3 neck bottle and add $45 \mathrm{ml} \mathrm{DDH} 2 \mathrm{O}$, leaching $90 \mathrm{~min}$ at $100 \mathrm{C}$. } \\
\hline \multicolumn{7}{|c|}{ Filter it and transfer leachate to $50 \mathrm{ml}$ volumetric bottle. } \\
\hline (4). Take $2 \mathrm{ml}$ leachat & add $10 \mathrm{ml} 10 \%$ & $\mathrm{BaCl} 2$ and titrate & with $0.1 \mathrm{M} \mathrm{HCl}$. & & & \\
\hline
\end{tabular}


(Ti leaching data)

\begin{tabular}{|c|c|c|c|c|c|c|c|}
\hline Sample & Leachate Vol. & aliquot & {$[\mathrm{HCl}]$ titrant } & Vol. $\mathrm{HCl}$ & {$[\mathrm{NaOH}]$} & {$[\mathrm{NaOH}]$} & {$[\mathrm{NaOH}]$} \\
\hline ID & $(\mathrm{mL})$ & $(\mathrm{mL})$ & conc & $(\mathrm{mL})$ & $(\mathrm{mol} / \mathrm{L})$ & $(g / L)$ & (mol/g char) \\
\hline D02/24/04 & 50 & 2 & 0.1 & 5.944 & $2.97 \mathrm{E}-01$ & 11.89 & 4.95E-03 \\
\hline D02/24/04 & 50 & 2 & 0.1 & 0.612 & $3.06 \mathrm{E}-02$ & 1.22 & $5.10 \mathrm{E}-04$ \\
\hline D02/24/04 & & 1 & 0.1 & 0.330 & $3.30 \mathrm{E}-02$ & 1.32 & \\
\hline D02/24/04 & 50 & 2 & 0.1 & 0.248 & $1.24 \mathrm{E}-02$ & 0.50 & $2.07 \mathrm{E}-04$ \\
\hline & & & & & & & \\
\hline D02/24/04 & 30 & 1 & 0.1 & 12.770 & $1.28 \mathrm{E}+00$ & 51.08 & 6.39E-03 \\
\hline D02/24/04 & 30 & 1 & 0.1 & 0.668 & $6.68 \mathrm{E}-02$ & 2.67 & $3.34 \mathrm{E}-04$ \\
\hline D02/24/04 & $30 \mathrm{ml} \mathrm{H} 2 \mathrm{O}$ & 1 & 0.1 & 0.162 & $1.62 \mathrm{E}-02$ & 0.65 & $8.10 \mathrm{E}-05$ \\
\hline \multirow{2}{*}{ D03/01/04 } & about $225 \mathrm{ml}$ & 1 & 01 & 24266 & $243 \mathrm{~F}+00$ & 0706 & \\
\hline & & 0.5 & 0.1 & 12.540 & $2.51 \mathrm{E}+00$ & 100.32 & \\
\hline & & & & & & & \\
\hline P050603 & $45 \mathrm{ml} \mathrm{H} 2 \mathrm{O}$ & 1 & 0.1 & 5.076 & 5.08E-01 & 20.30 & \\
\hline P050603 & $35 \mathrm{ml}$ & 1 & 0.1 & 10.440 & $1.04 \mathrm{E}+00$ & 41.76 & \\
\hline P050621(very loose) & $30 \mathrm{ml}$ & 1 & 01 & 9552 & 9 55F-01 & 3821 & \\
\hline \multirow[t]{2}{*}{ P050621(very loose) } & $23 \mathrm{ml}$ & & & & & & \\
\hline & & & & & & & \\
\hline D02/19/03 & $50 \mathrm{ml} \mathrm{H} 2 \mathrm{O}$ & 1 & 0.1 & 4.628 & 4.63E-01 & 18.51 & \\
\hline $\mathrm{D} 02 / 19 / 03$ & $35 \mathrm{ml}$ & 1 & 0.1 & 11.684 & $1.17 \mathrm{E}+00$ & 46.74 & \\
\hline & & & & & & & \\
\hline D02/19/03 & $50 \mathrm{ml}$ & 1 & 0.1 & 5.332 & $5.33 \mathrm{E}-01$ & 21.33 & \\
\hline $\mathrm{D} 02 / 19 / 03$ & $35 \mathrm{ml}$ & 1 & 0.1 & 12.278 & $1.23 \mathrm{E}+00$ & 49.11 & \\
\hline $\mathrm{D} 02 / 19 / 03$ & & 1 & 0.1 & 18.764 & $1.88 \mathrm{E}+00$ & 75.06 & \\
\hline & & & & & & & \\
\hline D02/19/03 & & 1 & 0.1 & 21.958 & $2.20 \mathrm{E}+00$ & 87.83 & \\
\hline D06/17/03 & & 1 & 0.1 & 24.768 & $2.48 \mathrm{E}+00$ & 99.07 & \\
\hline & & & & & & & \\
\hline $7 / 27 / 2005$ & $40 \mathrm{ml} \mathrm{H} 2 \mathrm{O}$ & 1 & 0.1 & 4.792 & 4.79E-01 & 19.17 & \\
\hline $7 / 27 / 2005(2)$ & $40 \mathrm{ml} \mathrm{H} 2 \mathrm{O}$ & 1 & 0.1 & 5.228 & $5.23 \mathrm{E}-01$ & 20.91 & \\
\hline \multicolumn{8}{|c|}{${ }^{*}$ split a lot of solids out. } \\
\hline \multirow{2}{*}{\multicolumn{8}{|c|}{\begin{tabular}{|l|l|l|l|l|}
$* *$ & & & \\
$* * *$ \\
$*$ Leaching solution pink will come back a little bit $(0.058-0.094 \mathrm{ml})$ after it reaches to end points for PEFR runs.
\end{tabular}}} \\
\hline & & & & & & & \\
\hline \multicolumn{8}{|l|}{ Reference: } \\
\hline D02/24/04 & 250 & 25 & 0.1 & 3.744 & $1.50 \mathrm{E}-02$ & 0.60 & \\
\hline D02/19/03 & & 25 & 0.1 & 3.946 & $1.58 \mathrm{E}-02$ & 0.63 & \\
\hline $\mathrm{D} 06 / 17 / 03$ & & 25 & 0.1 & 1.710 & $6.84 \mathrm{E}-03$ & 0.27 & \\
\hline \multirow{2}{*}{\multicolumn{8}{|c|}{ Procedure: }} \\
\hline & & & & & & & \\
\hline \multicolumn{8}{|c|}{ Filter it and transfer leachate to $50 \mathrm{ml}$ volumetric bottle. } \\
\hline \multicolumn{8}{|c|}{ (2). 2nd leaching: Dry about 30min leaching cake which is gotten from Procedure (1) with funnel in oven. } \\
\hline \multicolumn{8}{|c|}{ Transfer residual to 3 neck bottle and add $45 \mathrm{ml} \mathrm{DDH} 2 \mathrm{O}$, leachin } \\
\hline \multicolumn{8}{|c|}{ Filter it and transfer leachate to $50 \mathrm{ml}$ volumetric bottle. } \\
\hline \multicolumn{8}{|c|}{ (3). 3nd leaching: Dry about 30min leaching cake which is gotten from Procedure (2) with funnel in oven. } \\
\hline \multirow{2}{*}{\multicolumn{8}{|c|}{$\begin{array}{l}\text { Transfer residual to } 3 \text { neck bottle and add } 45 \mathrm{ml} \mathrm{DDH} 2 \mathrm{O} \text {, le } \\
\text { Filter it and transfer leachate to } 50 \mathrm{ml} \text { volumetric bottle. }\end{array}$}} \\
\hline \multicolumn{6}{|c|}{ Filter it and transfer leachate to $50 \mathrm{ml}$ volumetric bottle. } & & \\
\hline (4). Take $2 \mathrm{ml}$ leachat & e, add $10 \mathrm{ml} 10$ & $\mathrm{BaCl} 2$ & $d$ titrate with 0 & $\mathrm{HCl}$. & & & \\
\hline
\end{tabular}




\section{(Ti leaching data)}

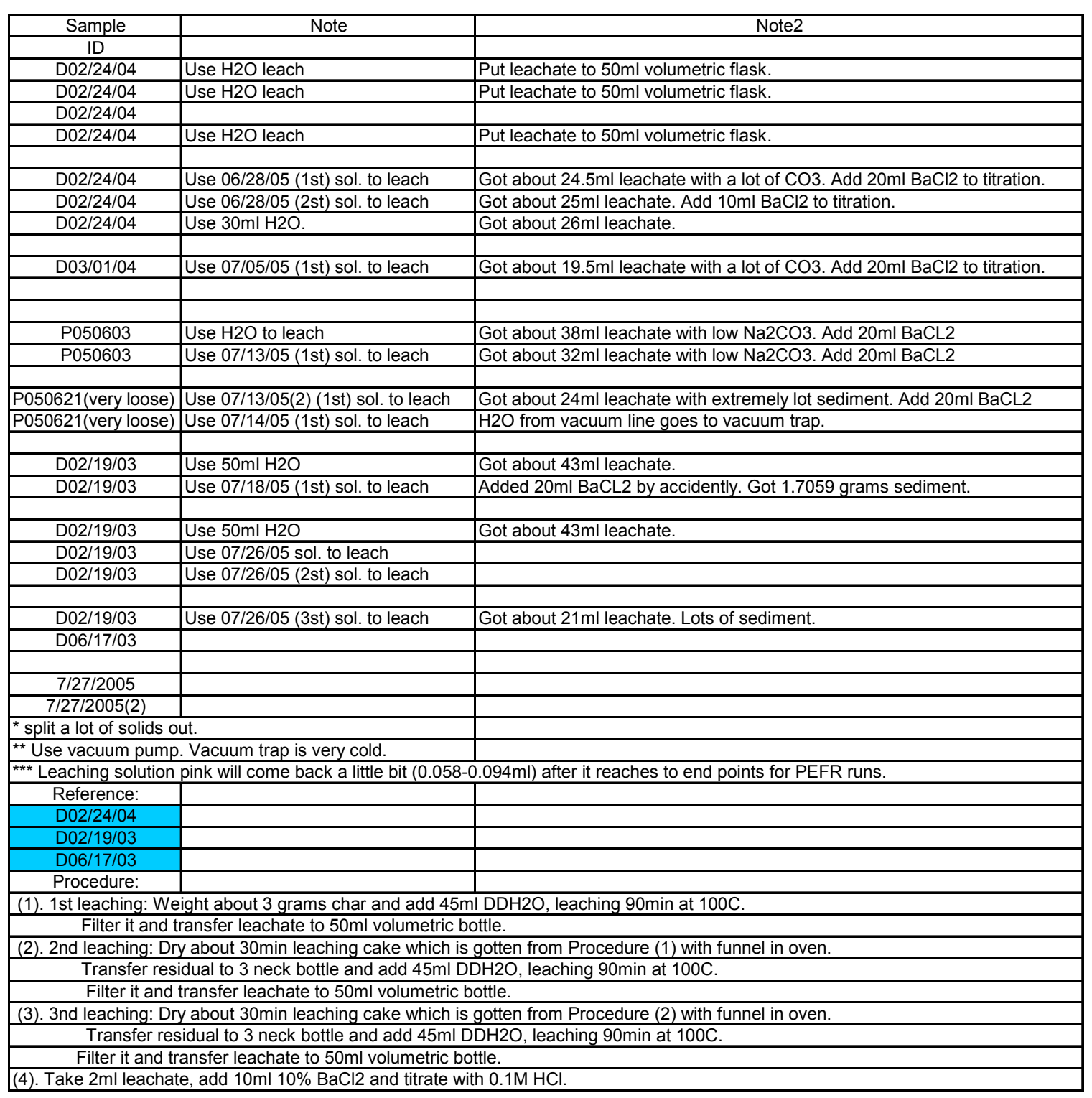


(Ti Leach)
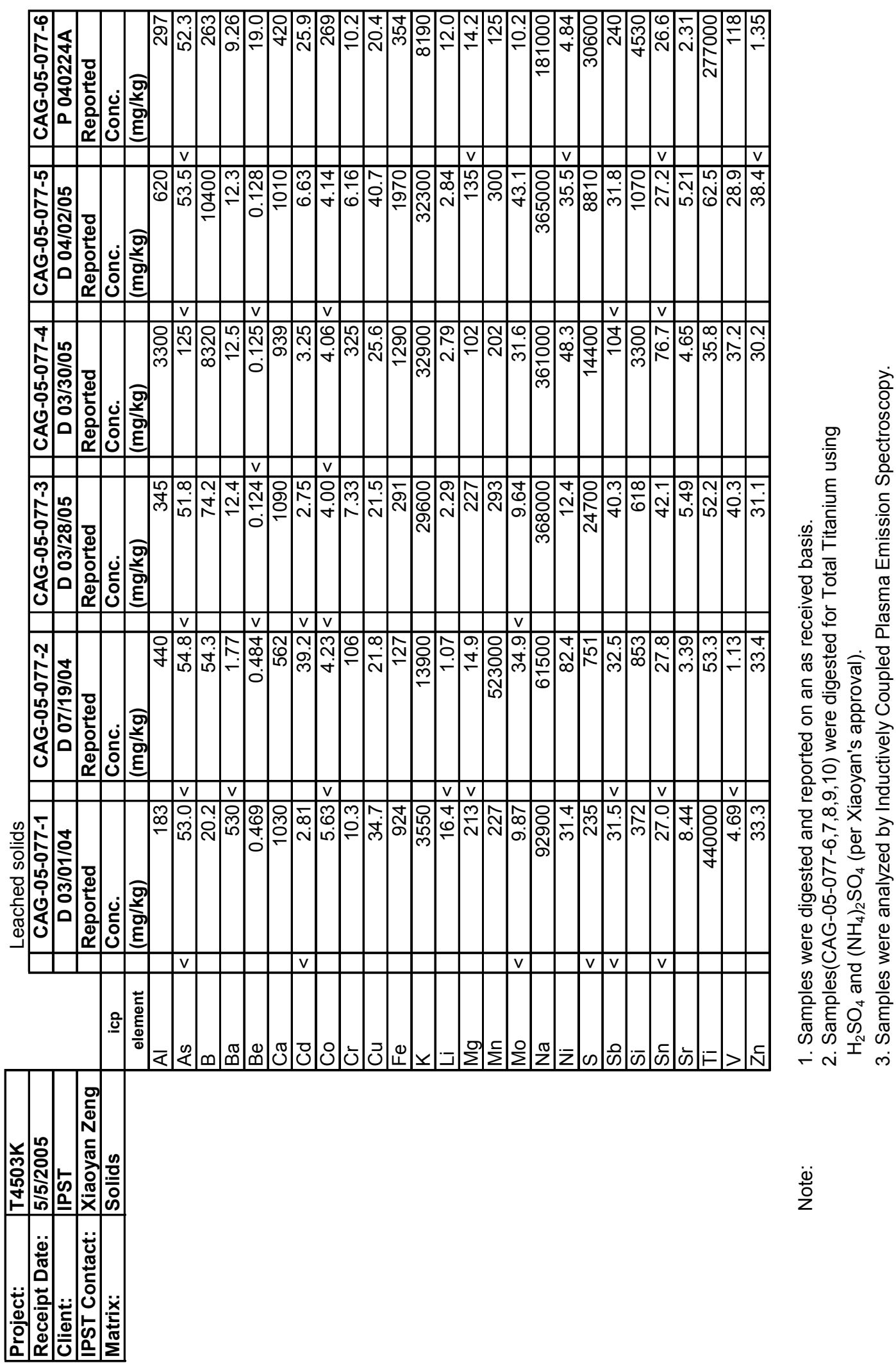

운 
(Ti Leach)

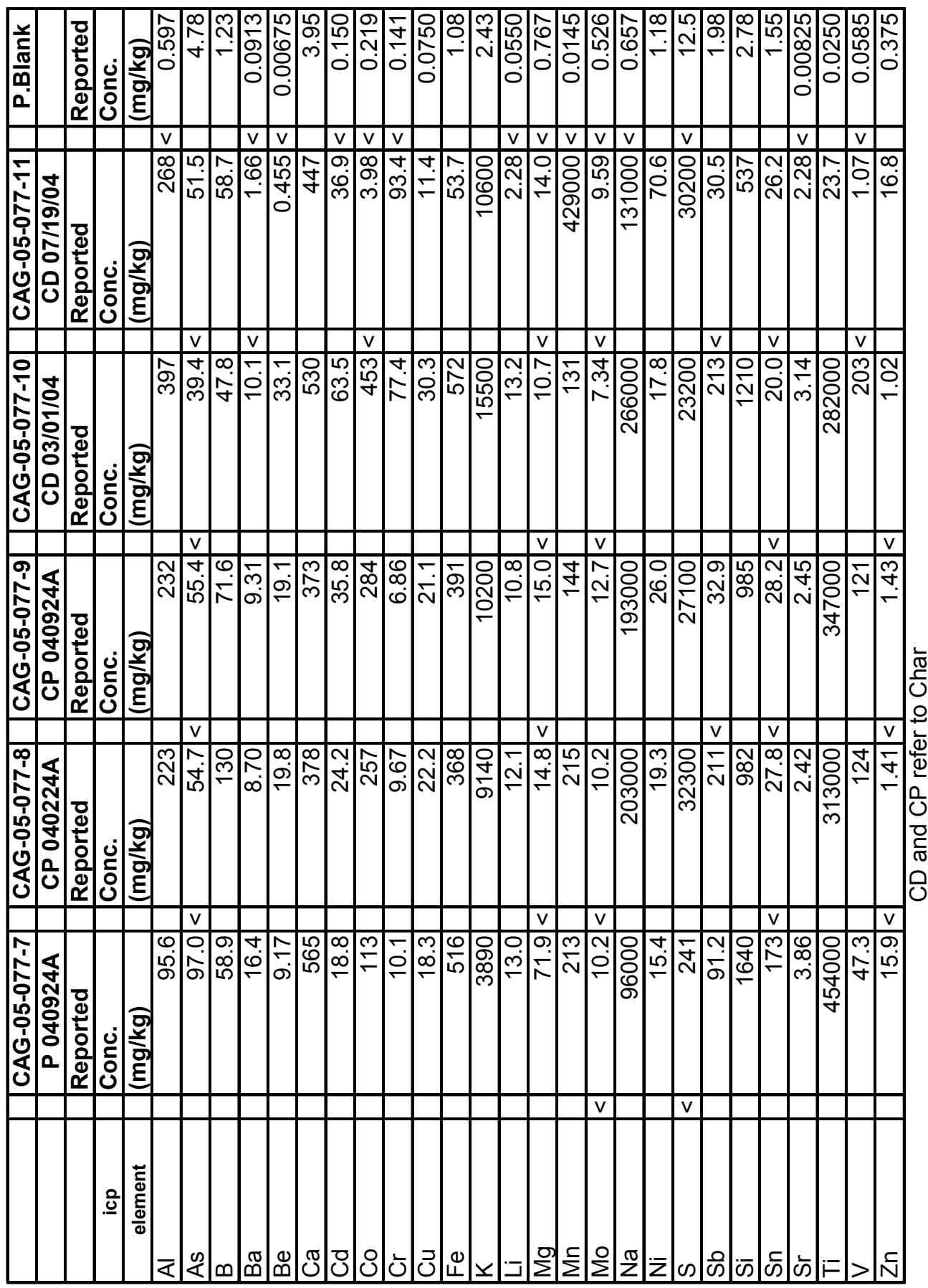


(Ti Leach)

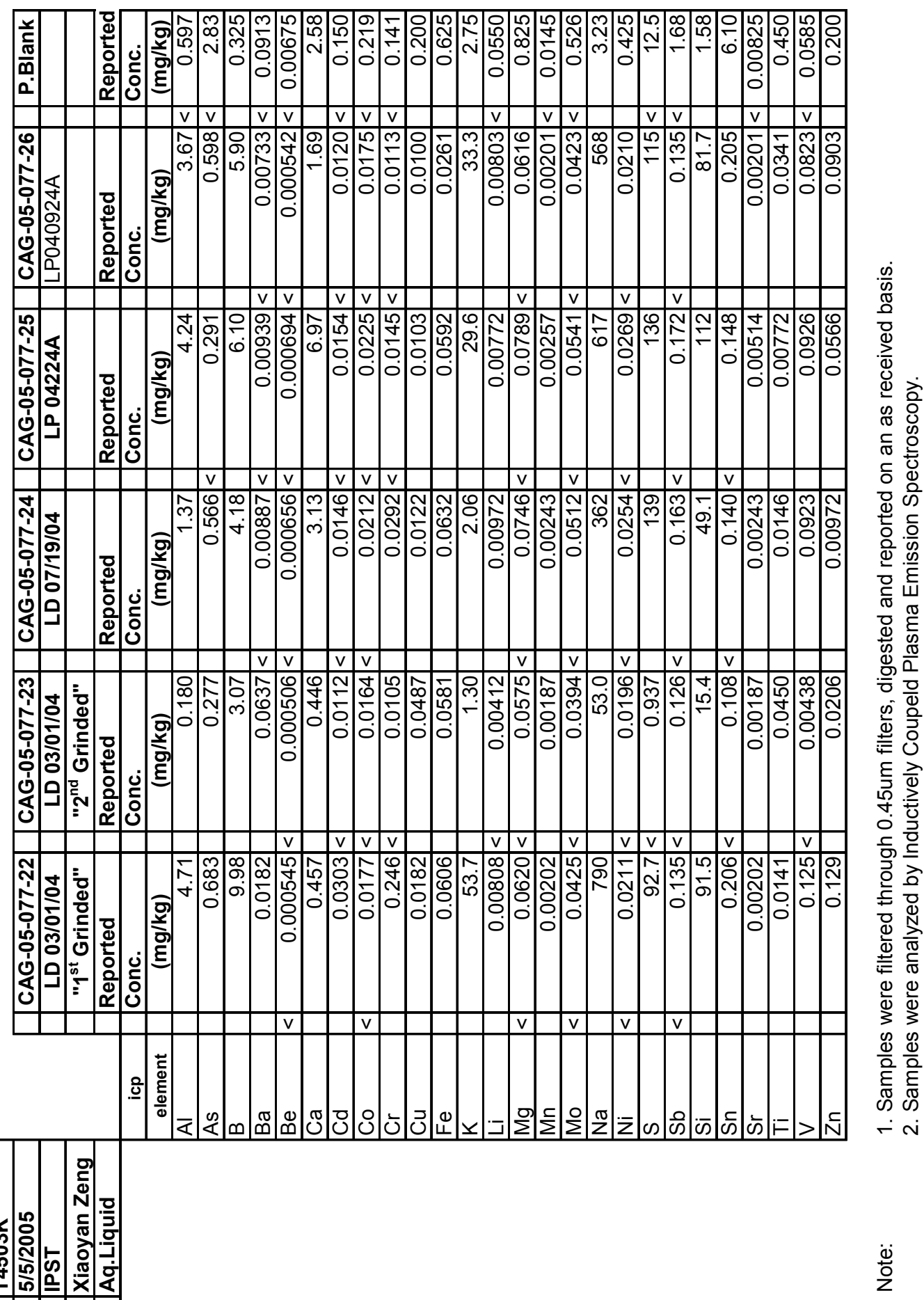


(Mn Leaching data)

\begin{tabular}{|c|c|c|c|c|c|c|c|}
\hline Sample & Leaching Time & Sample Wt. & Empty Funnel & \begin{tabular}{|l|} 
Funnel+Residue \\
\end{tabular} & Residue & Leachate Vol. & aliquot \\
\hline ID & $(\min )$ & $(\mathrm{g})$ & $(\mathrm{g})$ & $(g)$ & $(\mathrm{g})$ & $(\mathrm{mL})$ & $(\mathrm{mL})$ \\
\hline \multicolumn{8}{|c|}{ 03/07/05 Retitrate (with $\mathrm{BaCl} 2$ ) } \\
\hline $\mathrm{D} 07 / 08 / 03$ & 90 & 1.0005 & 60.4851 & 60.9750 & 0.4899 & 250 & 25 \\
\hline $\mathrm{D} 06 / 22 / 04$ & 90 & 1.0002 & 61.5305 & 62.3378 & 0.8073 & 250 & 25 \\
\hline $\mathrm{D} 07 / 06 / 04$ & 90 & 0.9997 & 60.5840 & 61.3867 & 0.8027 & 250 & 25 \\
\hline & & & & & & & \\
\hline $\mathrm{D} 06 / 22 / 04$ & 90 & 1.0002 & 61.5305 & 62.3378 & 0.8073 & 250 & 25 \\
\hline D07/06/04 & 90 & 0.9997 & 60.5840 & 61.3867 & 0.8027 & 250 & 25 \\
\hline D07/19/04 & 90 & 1.0000 & 61.167 & 61.9869 & 0.8199 & 250 & 25 \\
\hline $\mathrm{D} 07 / 19 / 04$ & 90 & 1.0000 & 61.167 & 61.9869 & 0.8199 & 250 & 25 \\
\hline $\mathrm{D} 07 / 26 / 04$ & 90 & 1.0001 & 76.1245 & 76.9378 & 0.8133 & 250 & 25 \\
\hline & & & & & & & \\
\hline \multicolumn{8}{|c|}{ 03/29/05 2nd leaching(Use sample after XRD) } \\
\hline $\mathrm{D} 06 / 22 / 04$ & 90 & 0.7982 & 60.5811 & 61.3565 & 0.7754 & 250 & 25 \\
\hline & & & & & & & \\
\hline & & & & & & & \\
\hline \multicolumn{8}{|c|}{ 01/18/06 Leaching and send samples to Mike } \\
\hline D07/19/04 & $1 \mathrm{st} 90 \mathrm{~min}$ & 1.0052 & 61.0939 & 61.8722 & 0.7783 & 250 & 25 \\
\hline D07/19/04 & 2 nd $90 \mathrm{~min}$ & 0.6346 & 61.4671 & 62.0973 & 0.6302 & 250 & 25 \\
\hline
\end{tabular}

(same table continued)

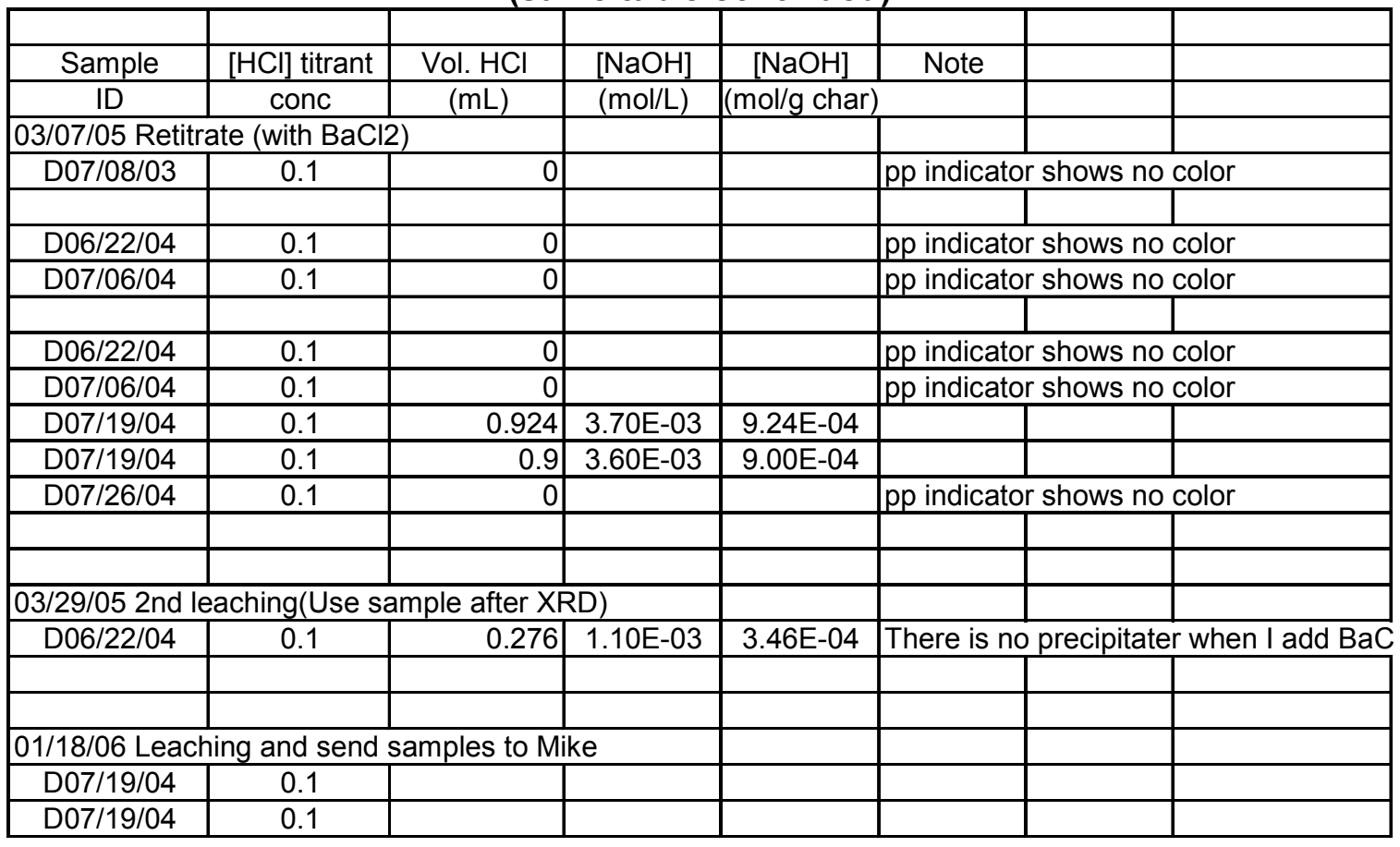


(Mn Leaching)
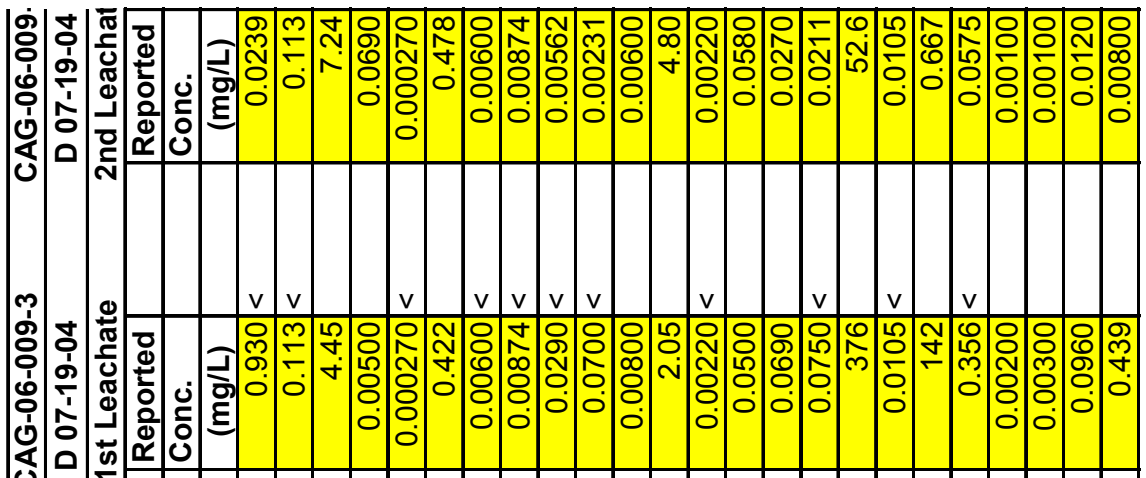

ڤ̊.

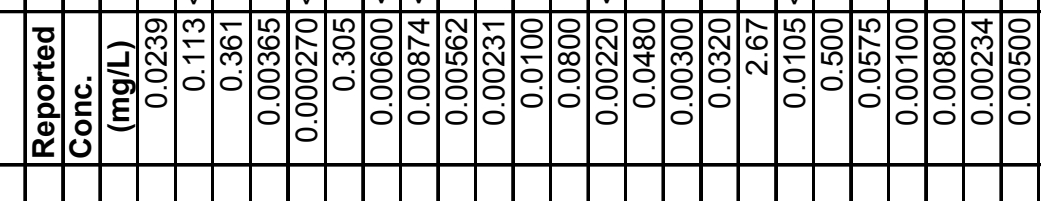

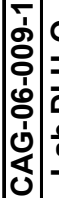
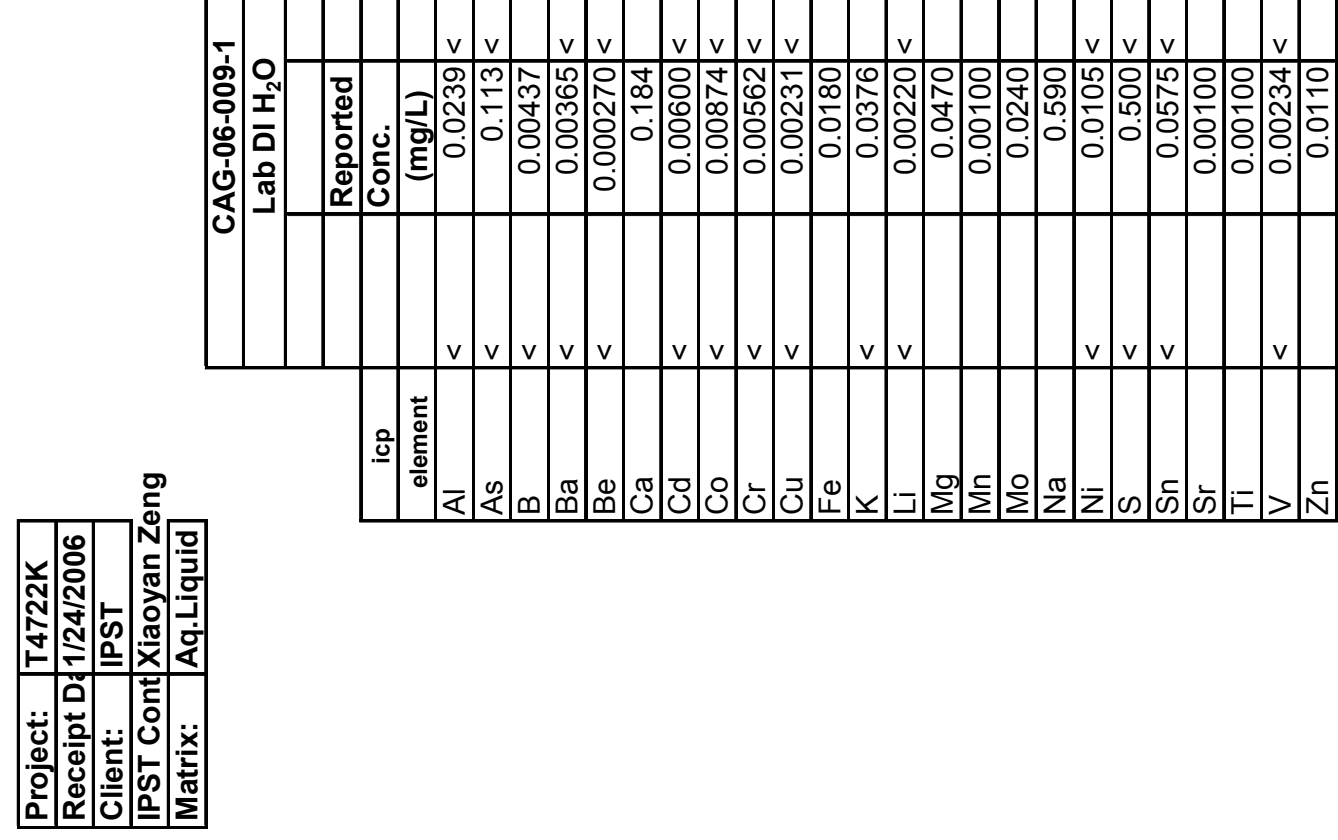

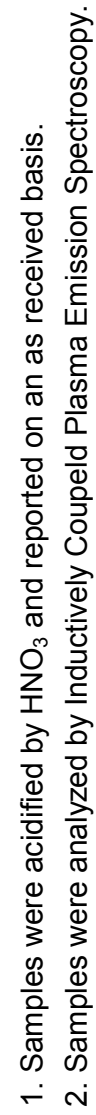


(Mn Leaching)
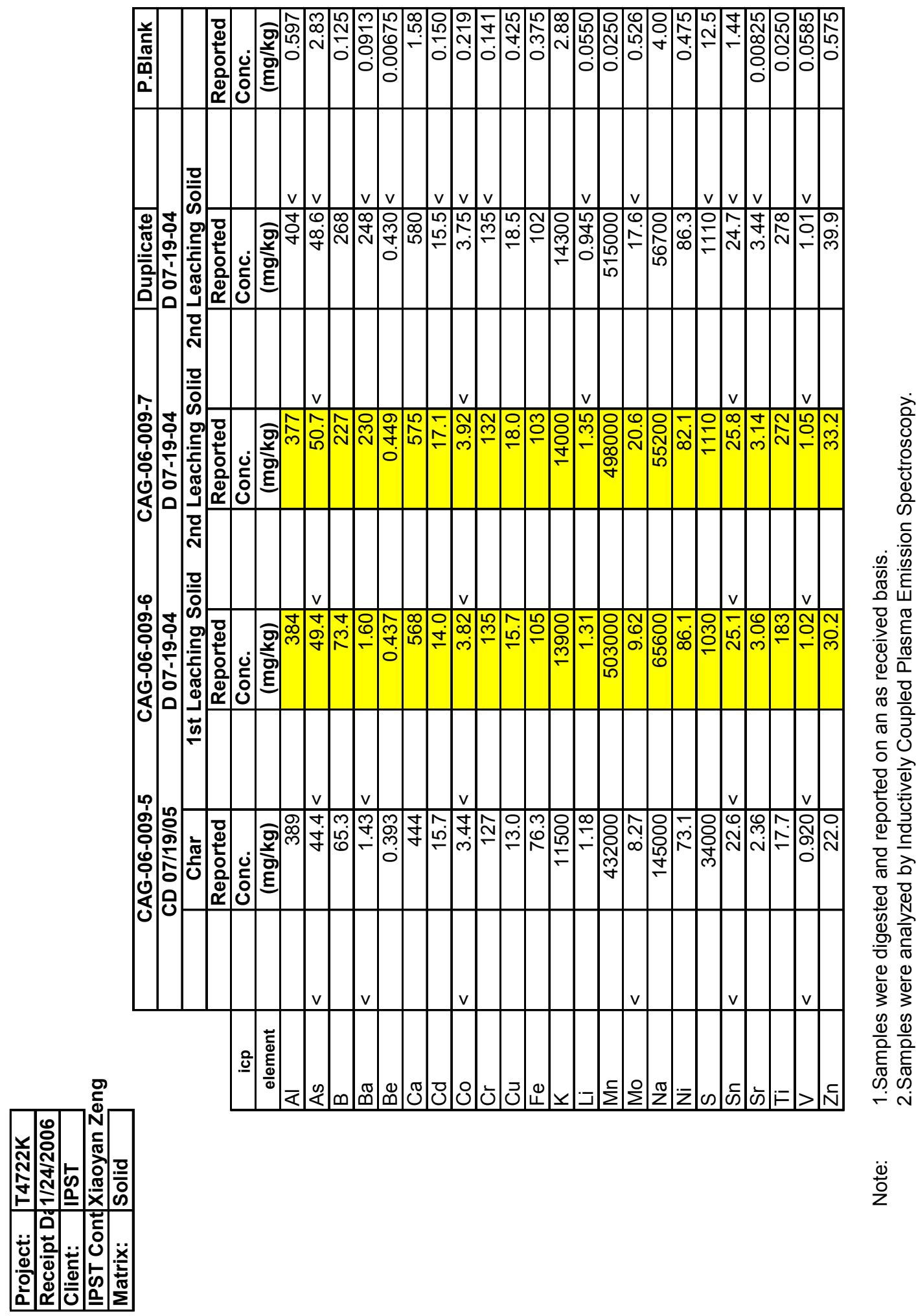


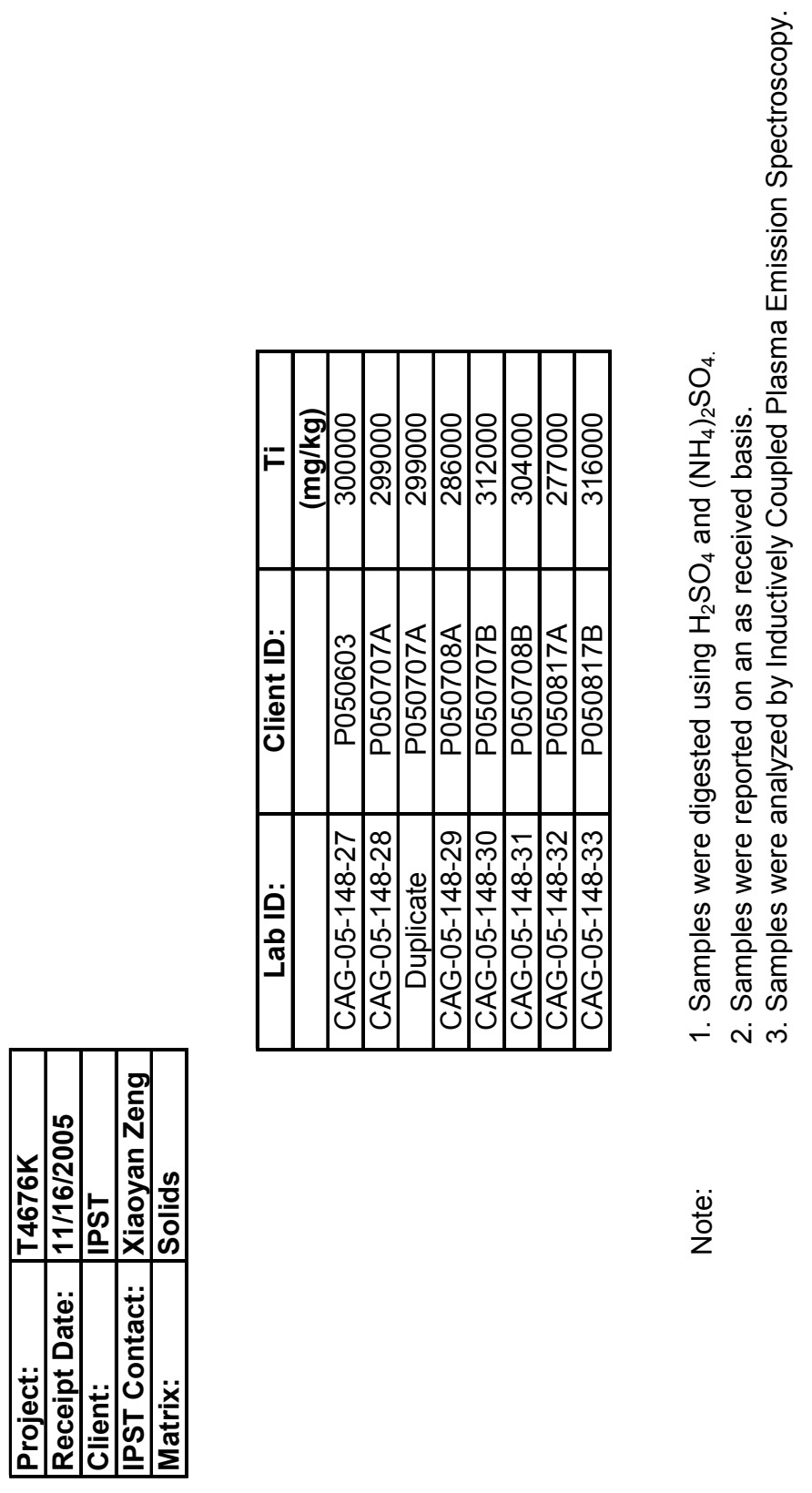




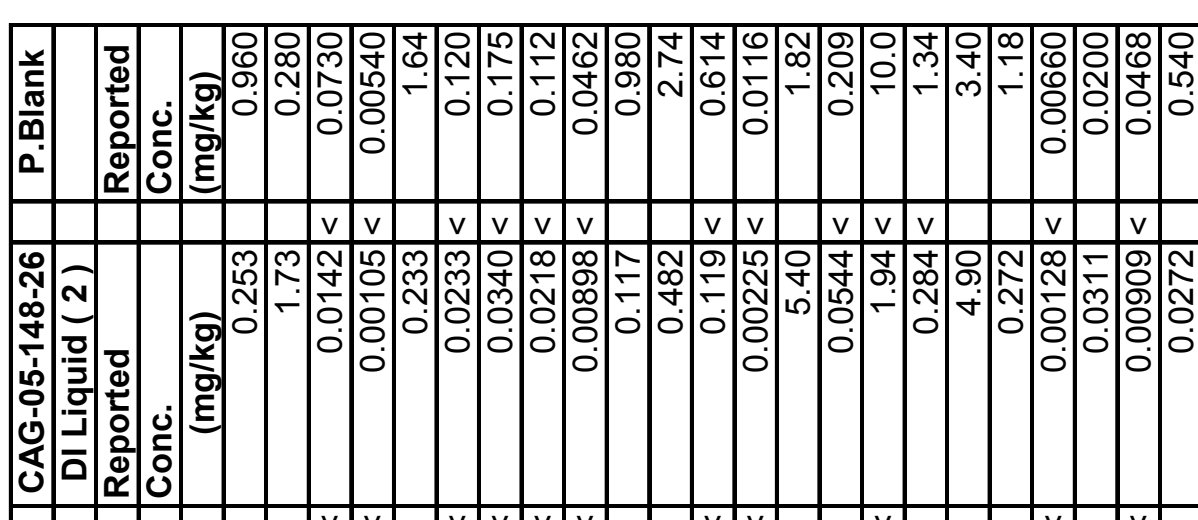

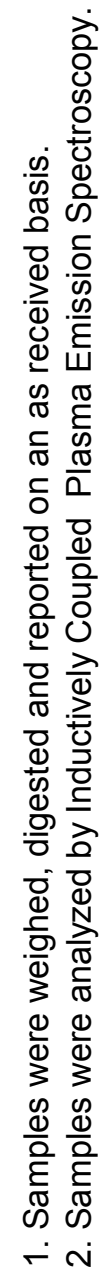

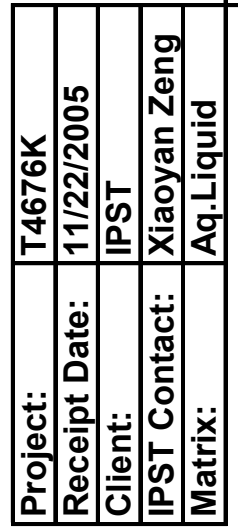

《
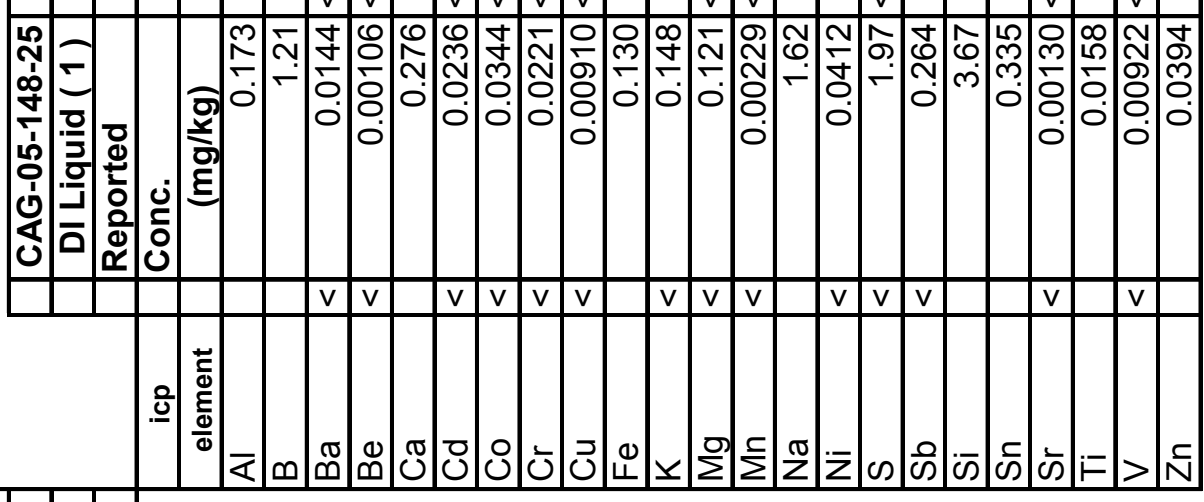

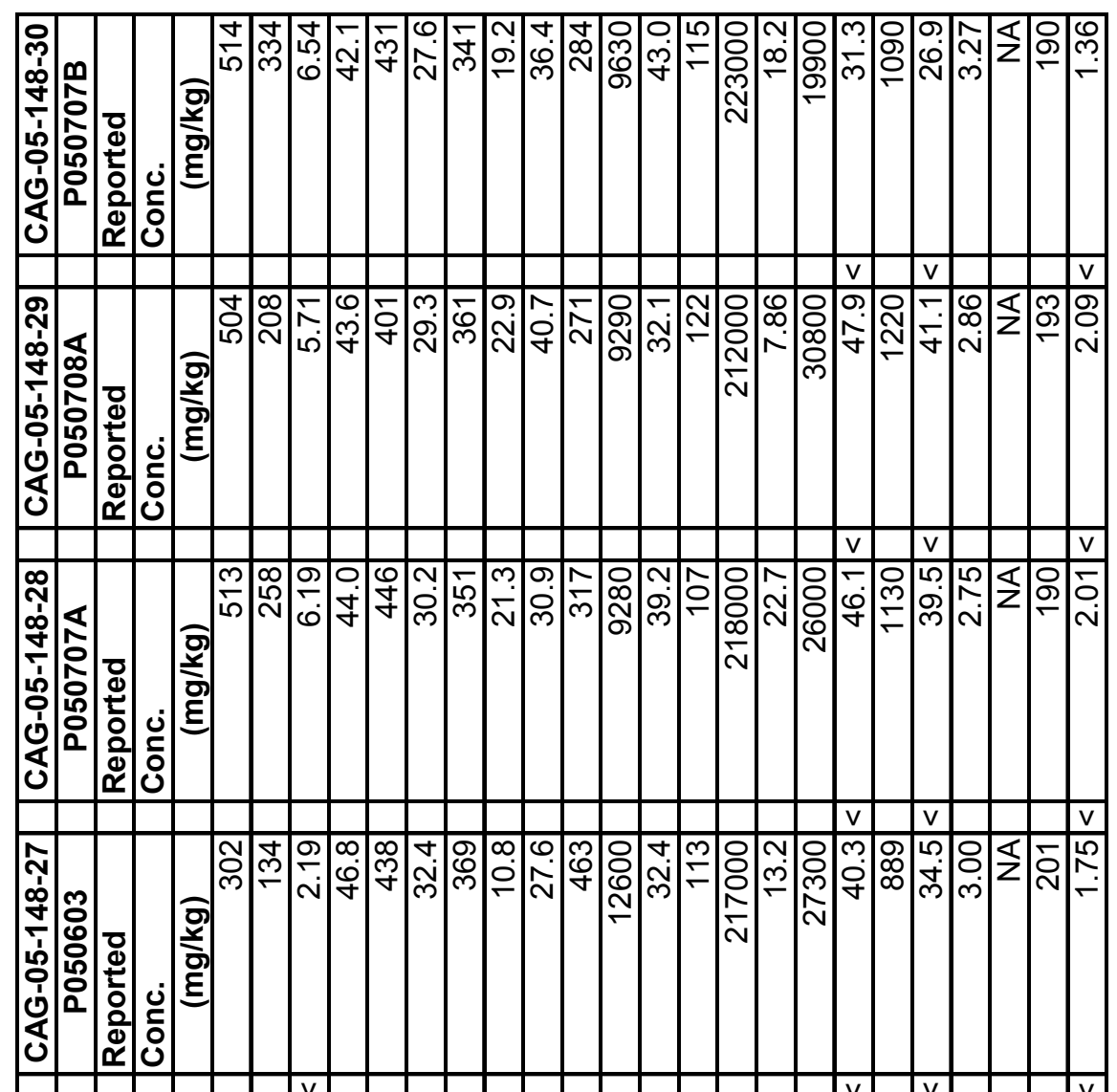

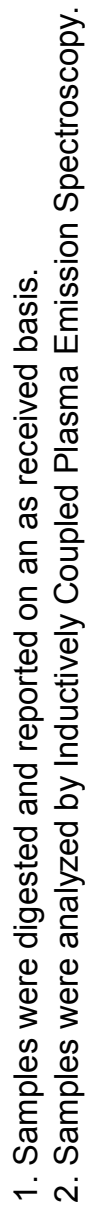

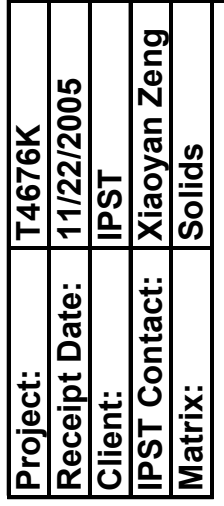

$\frac{0}{0}$ 


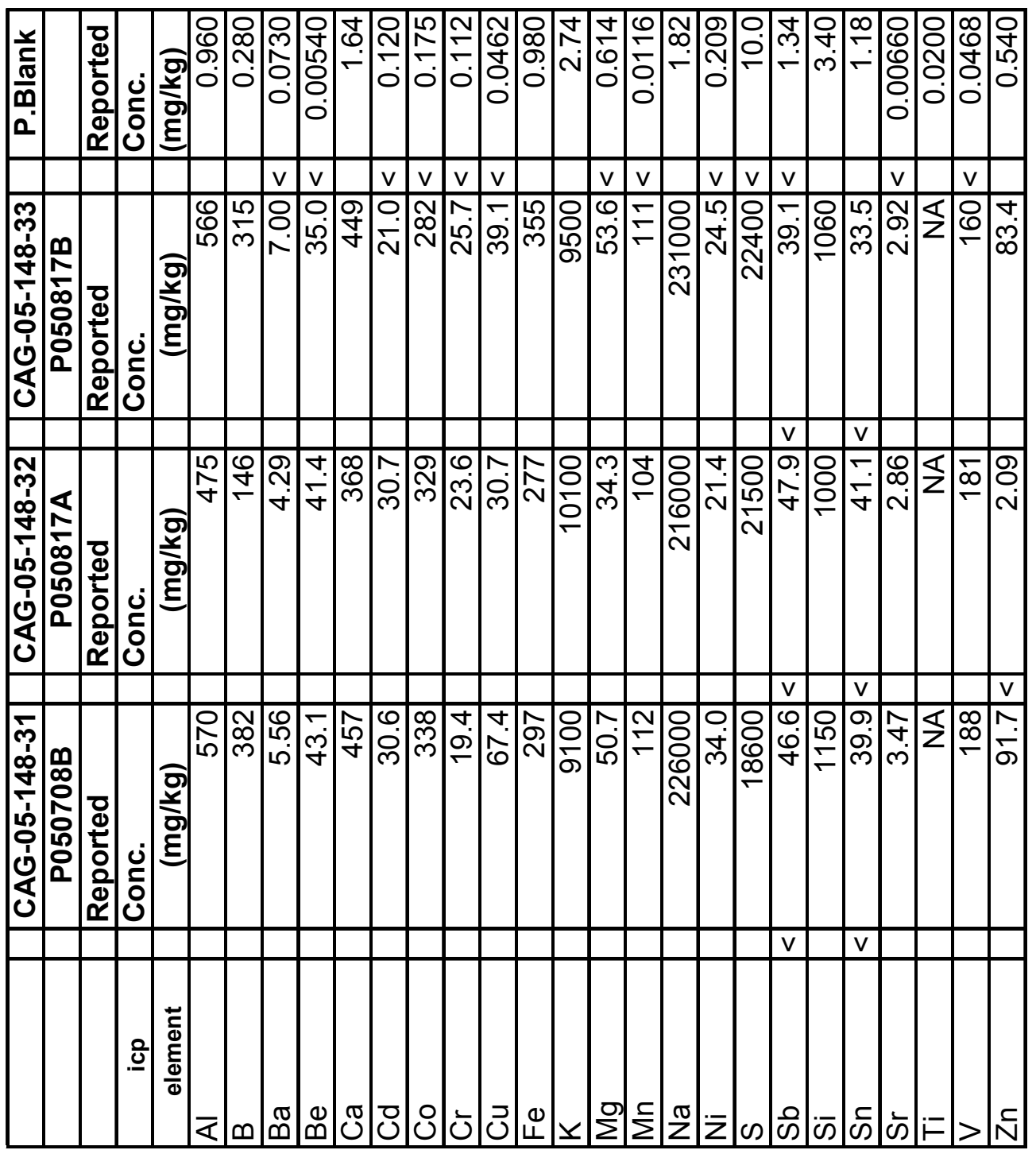



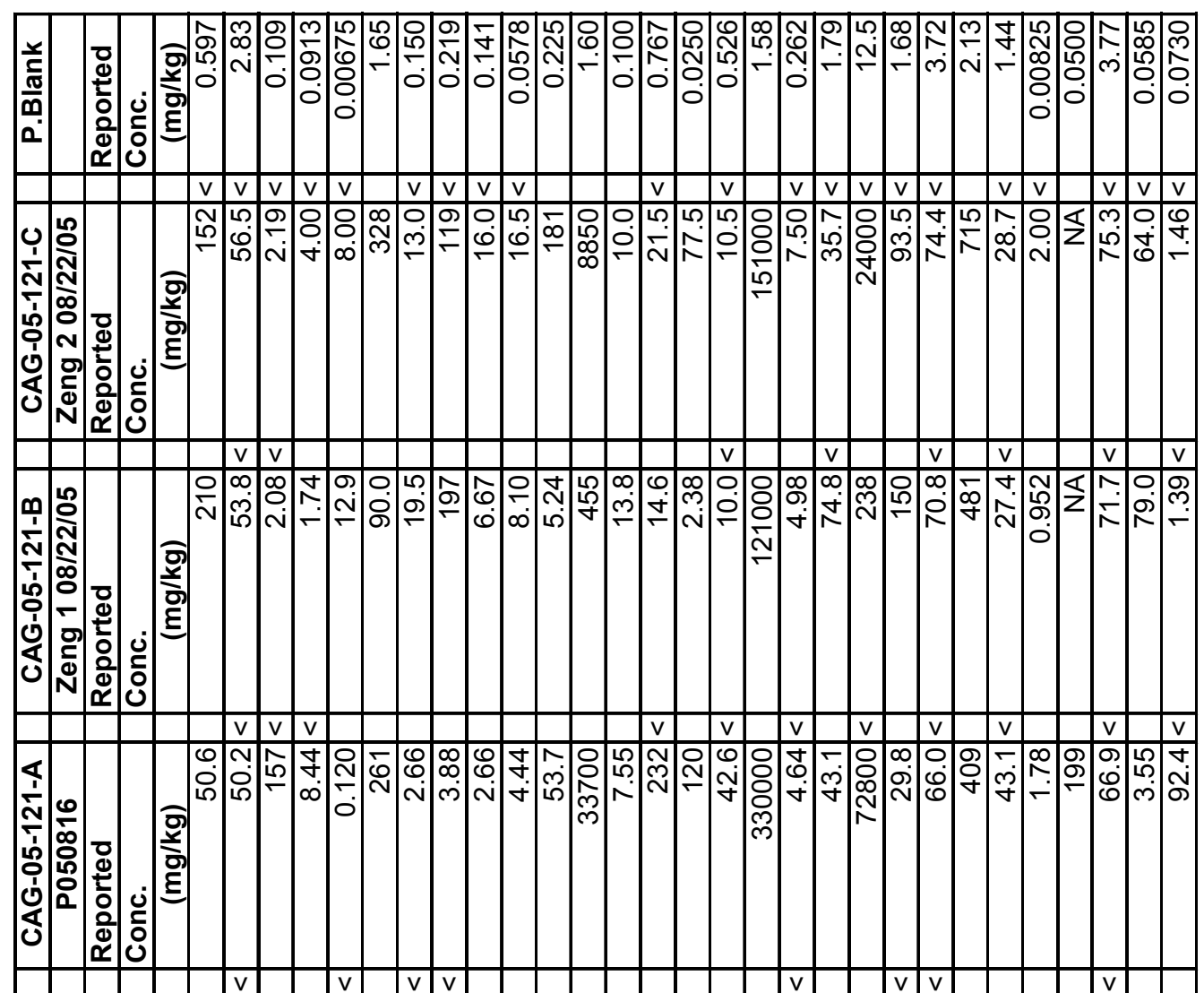

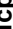

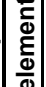

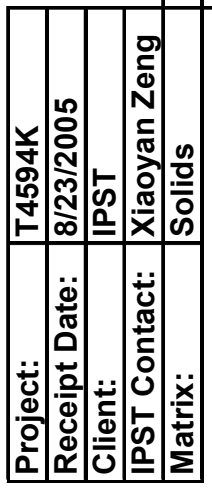

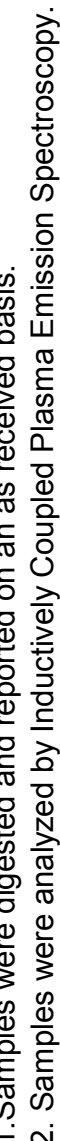

문 


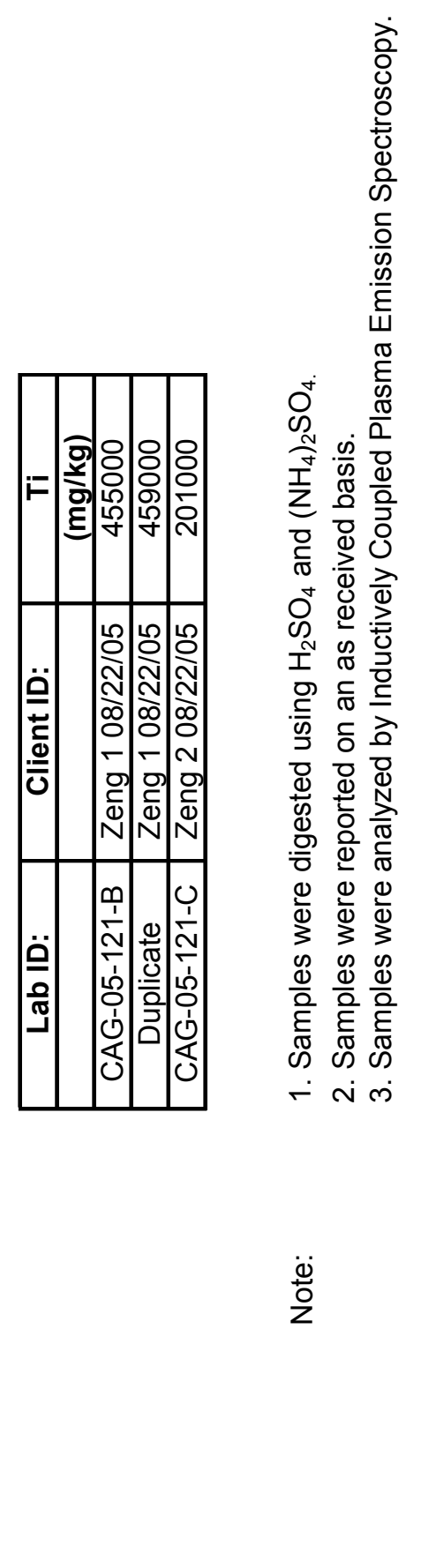




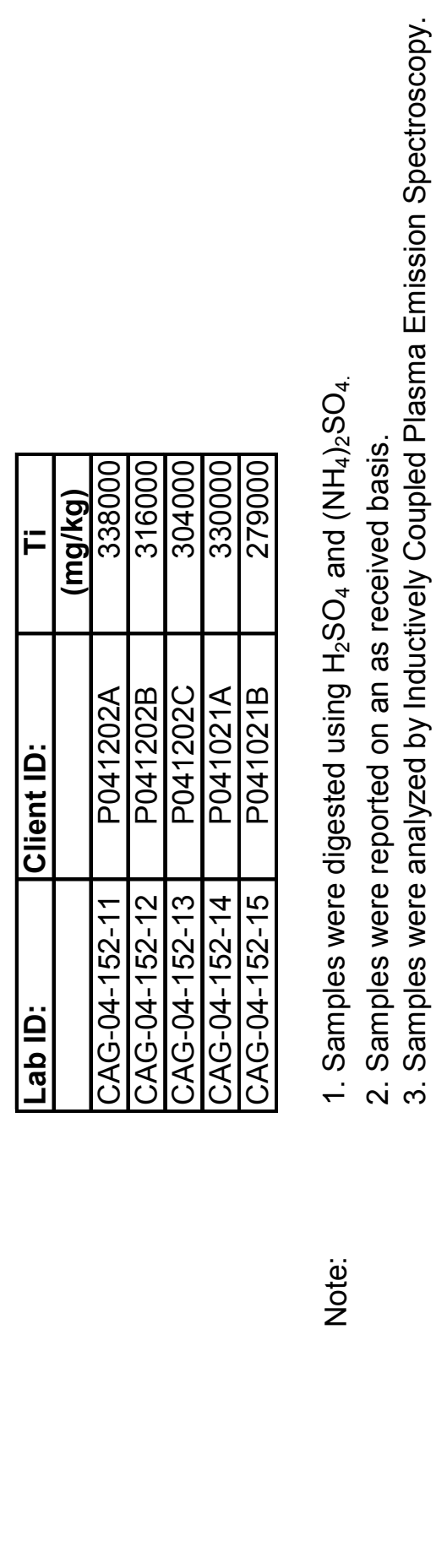




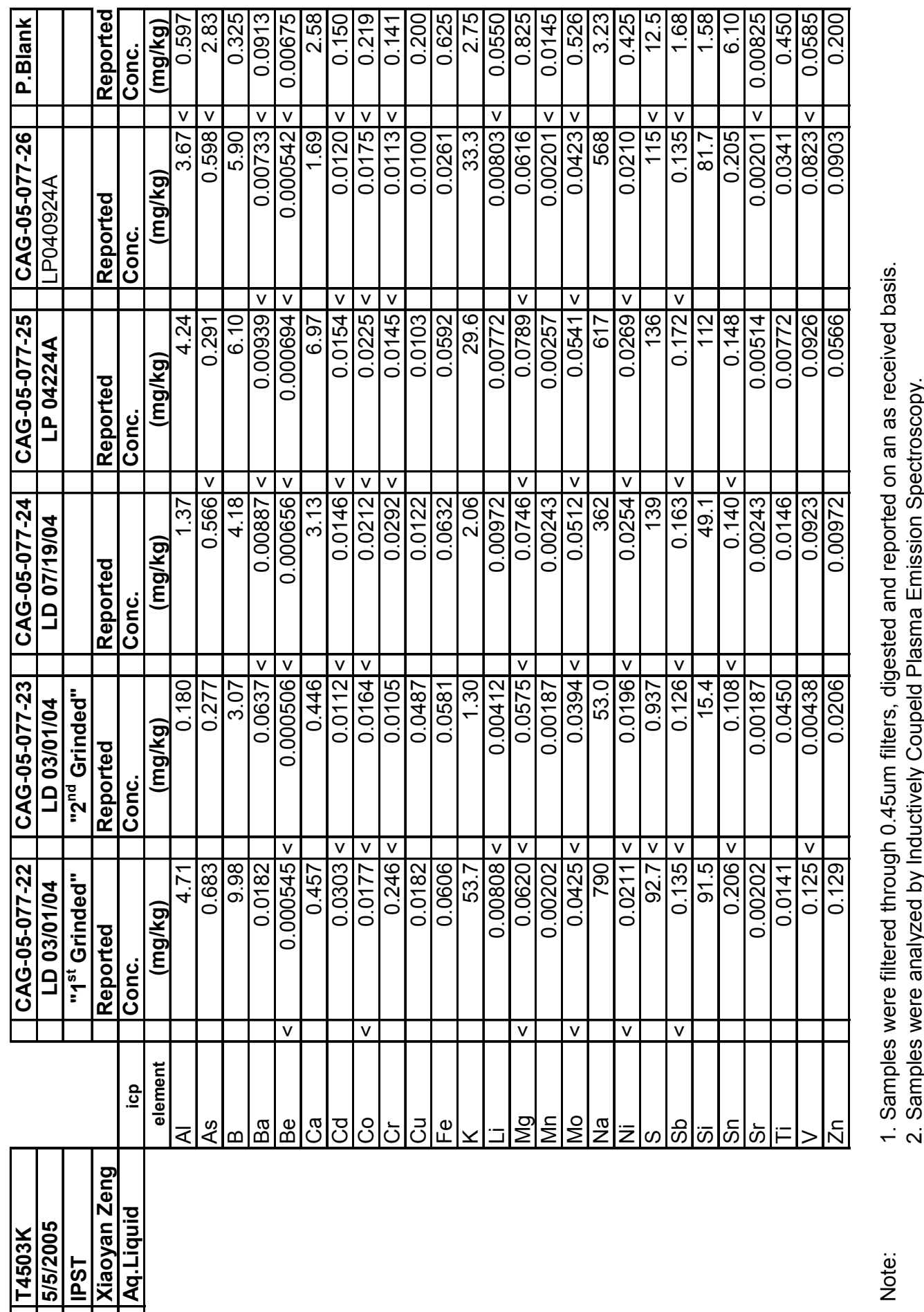




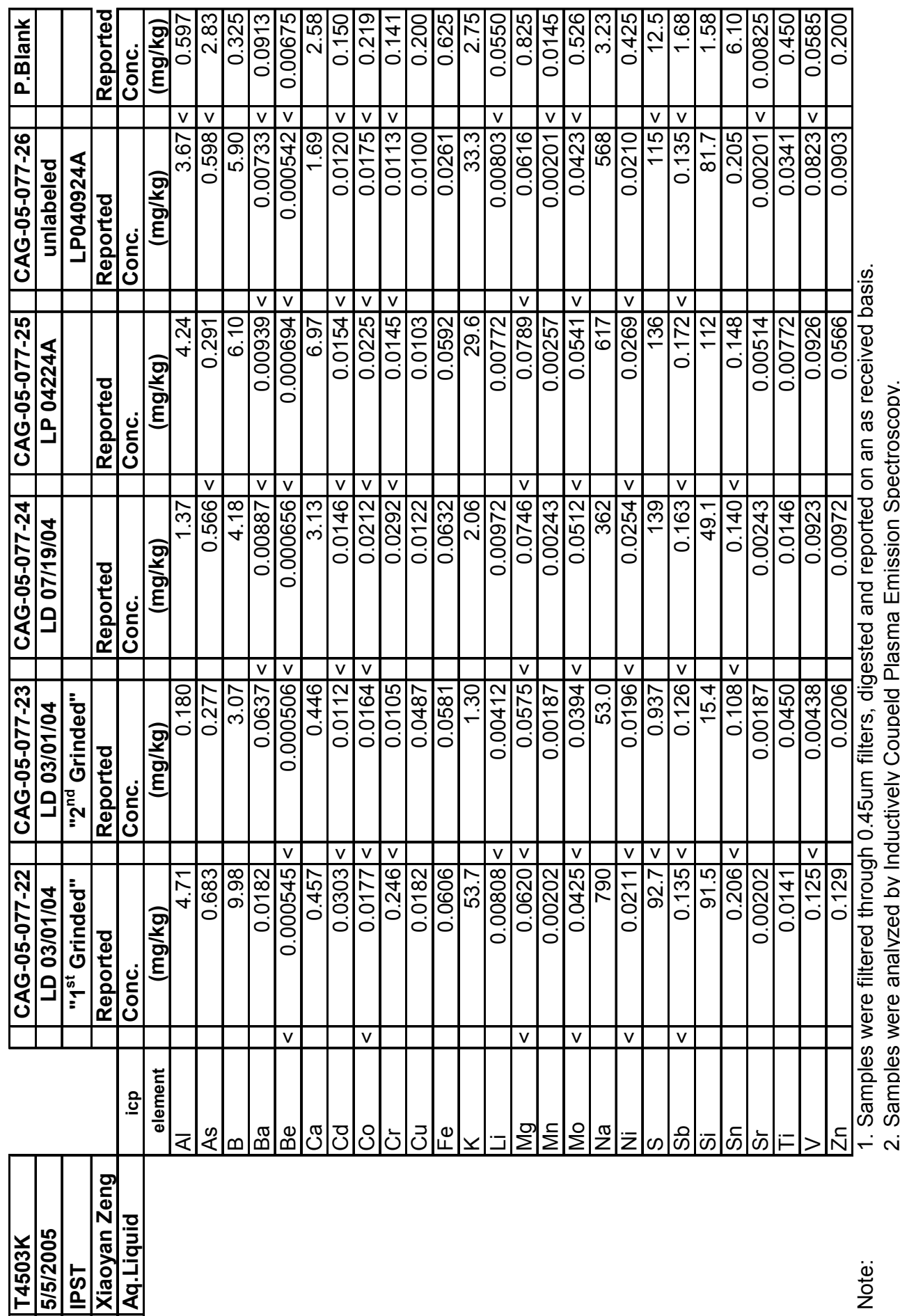




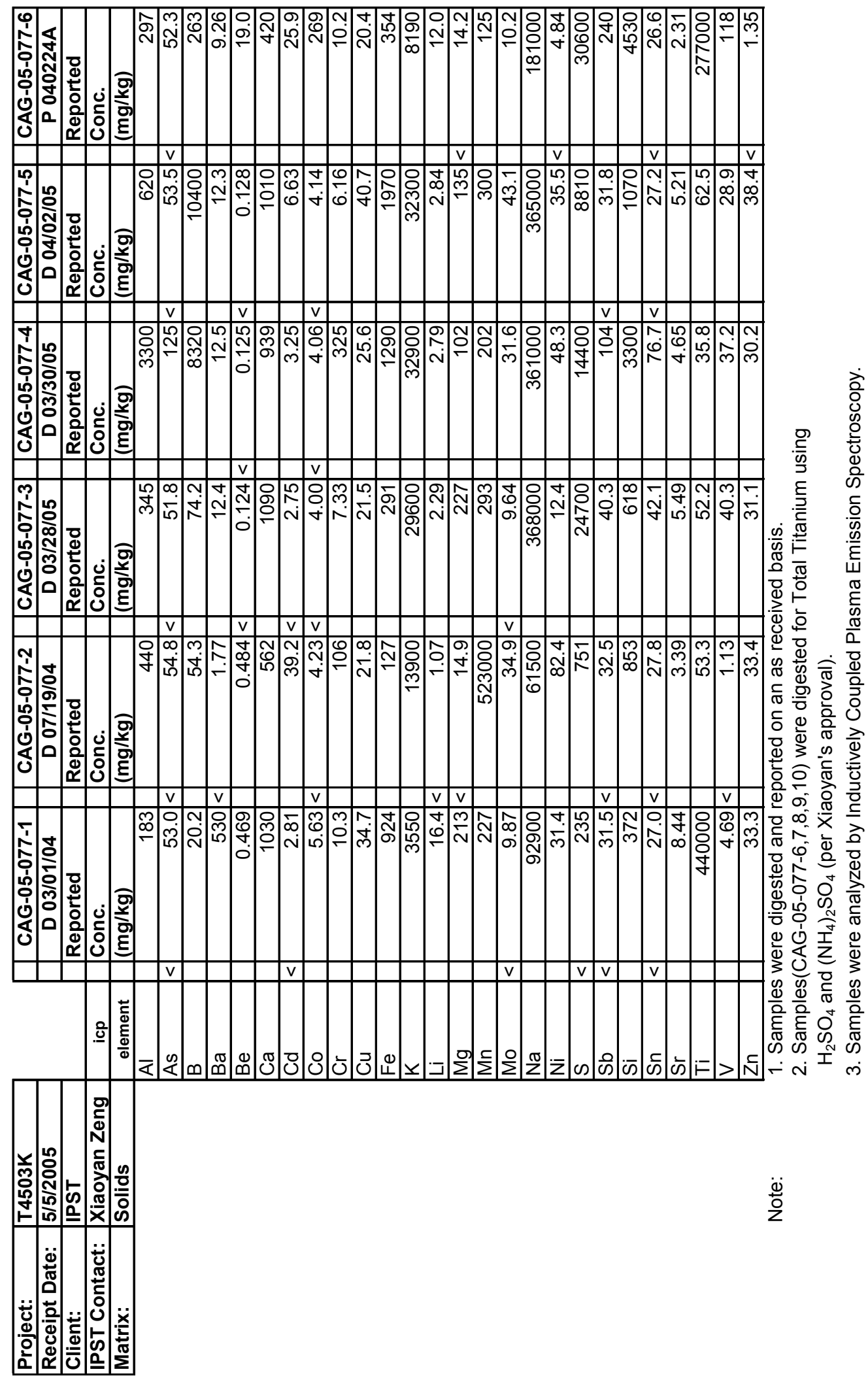




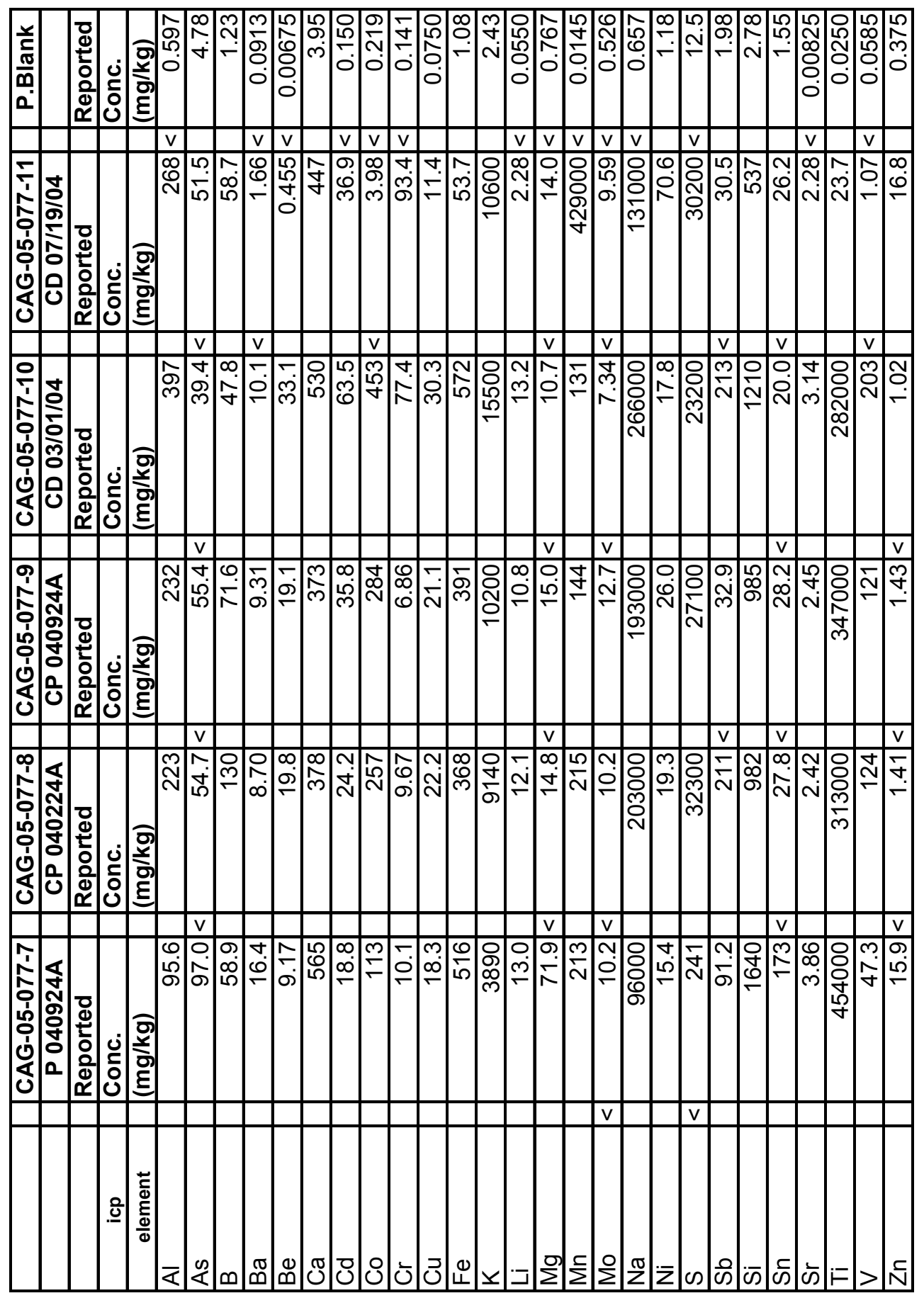



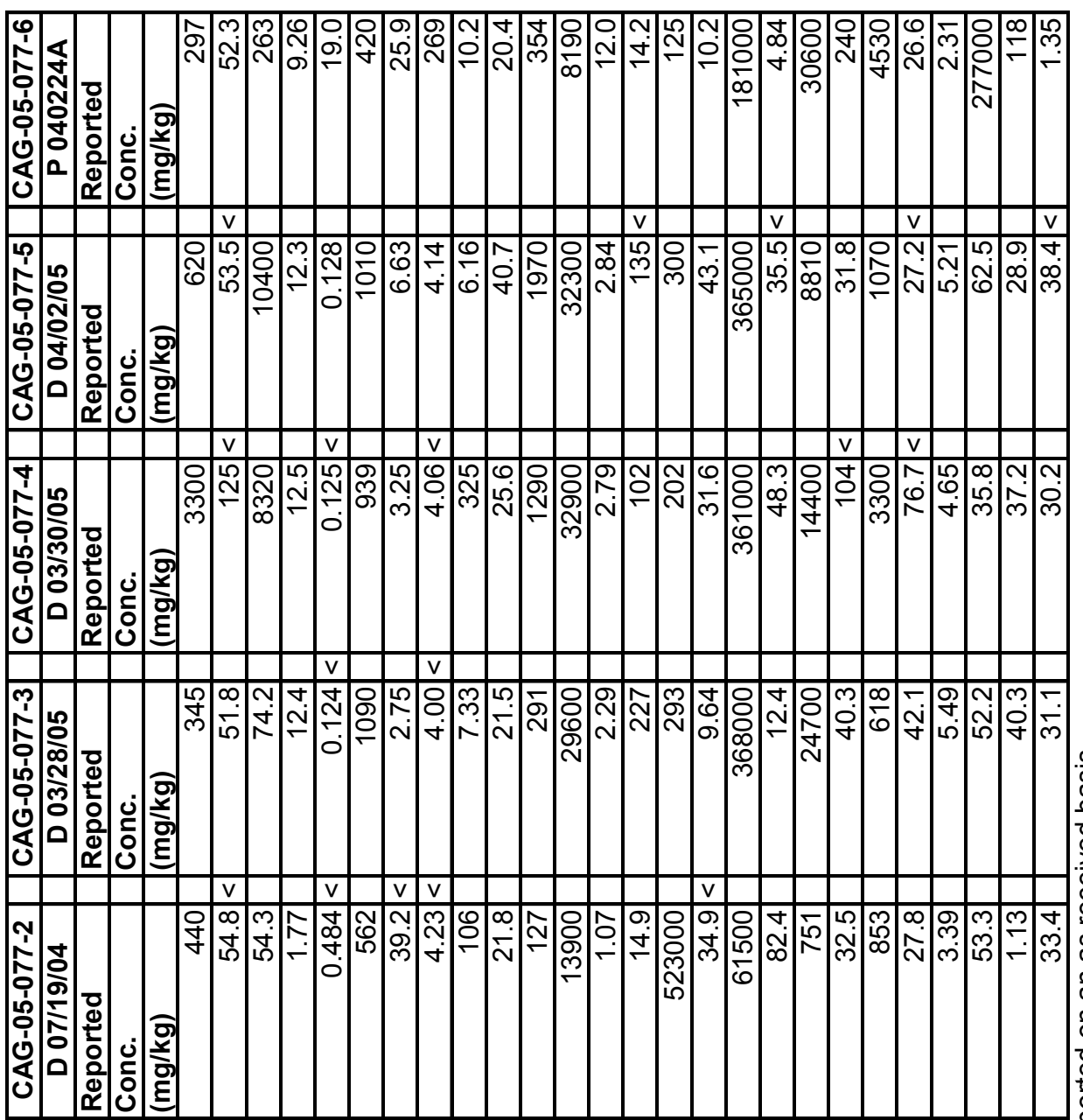

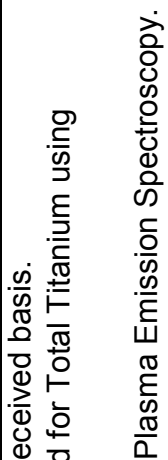

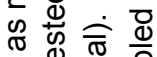

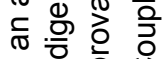
ㄷㅇ응 0 ब \& 3 क क 능 은

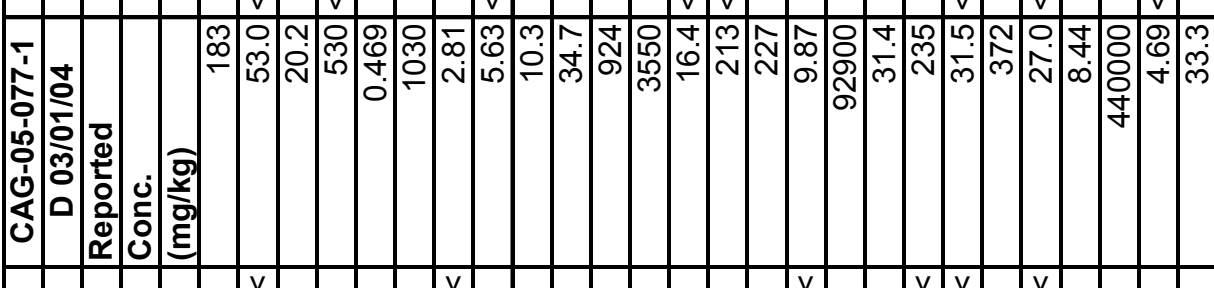
웡 을 它全京 व 范全 政 ब.

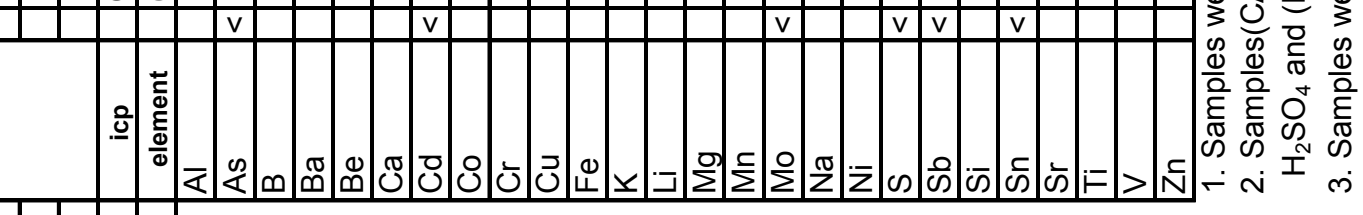

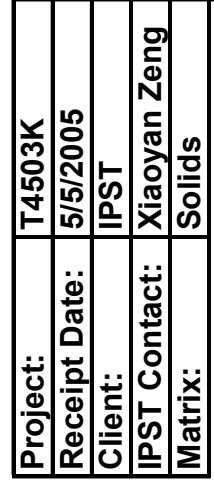



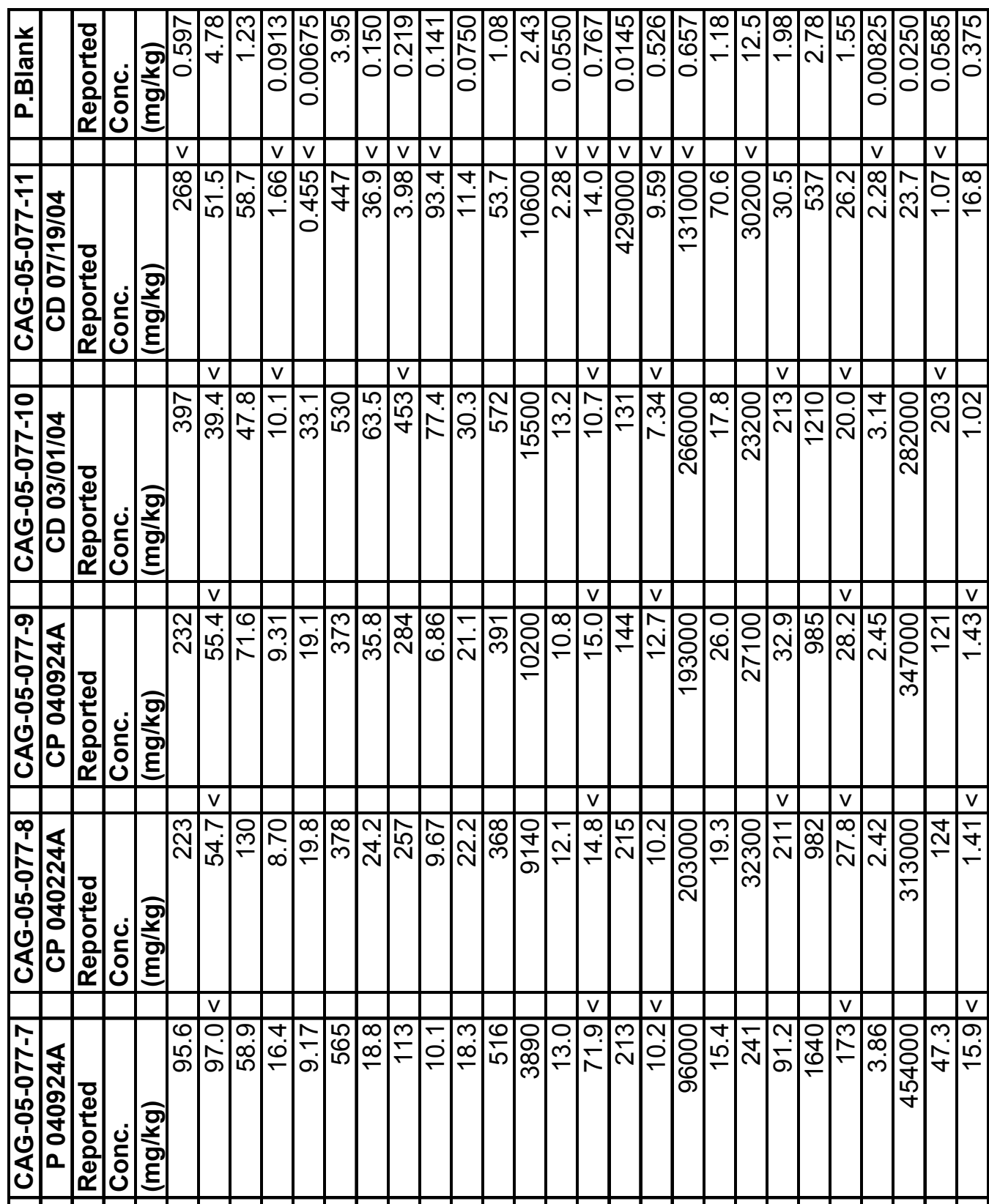

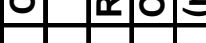

응

选是 


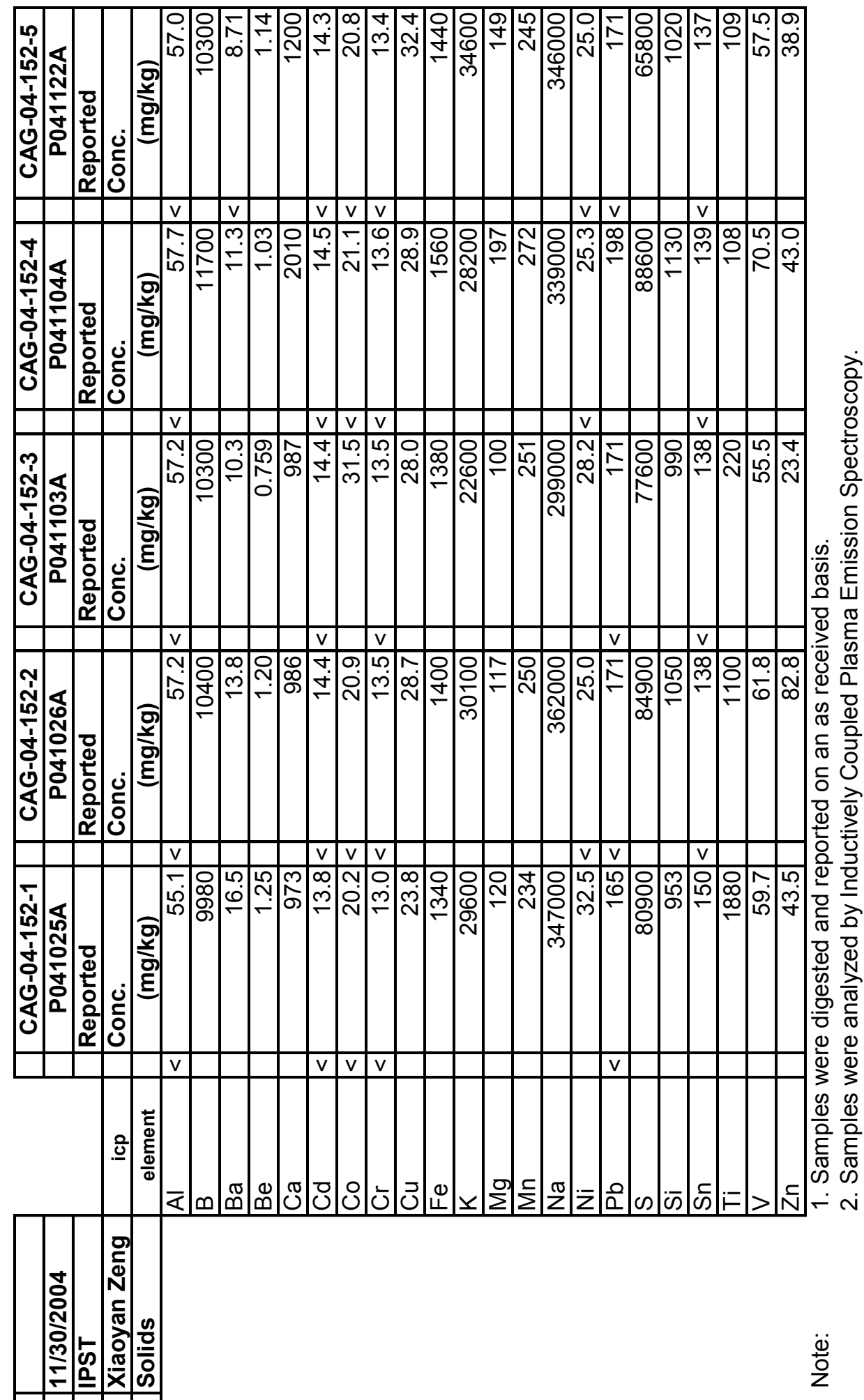



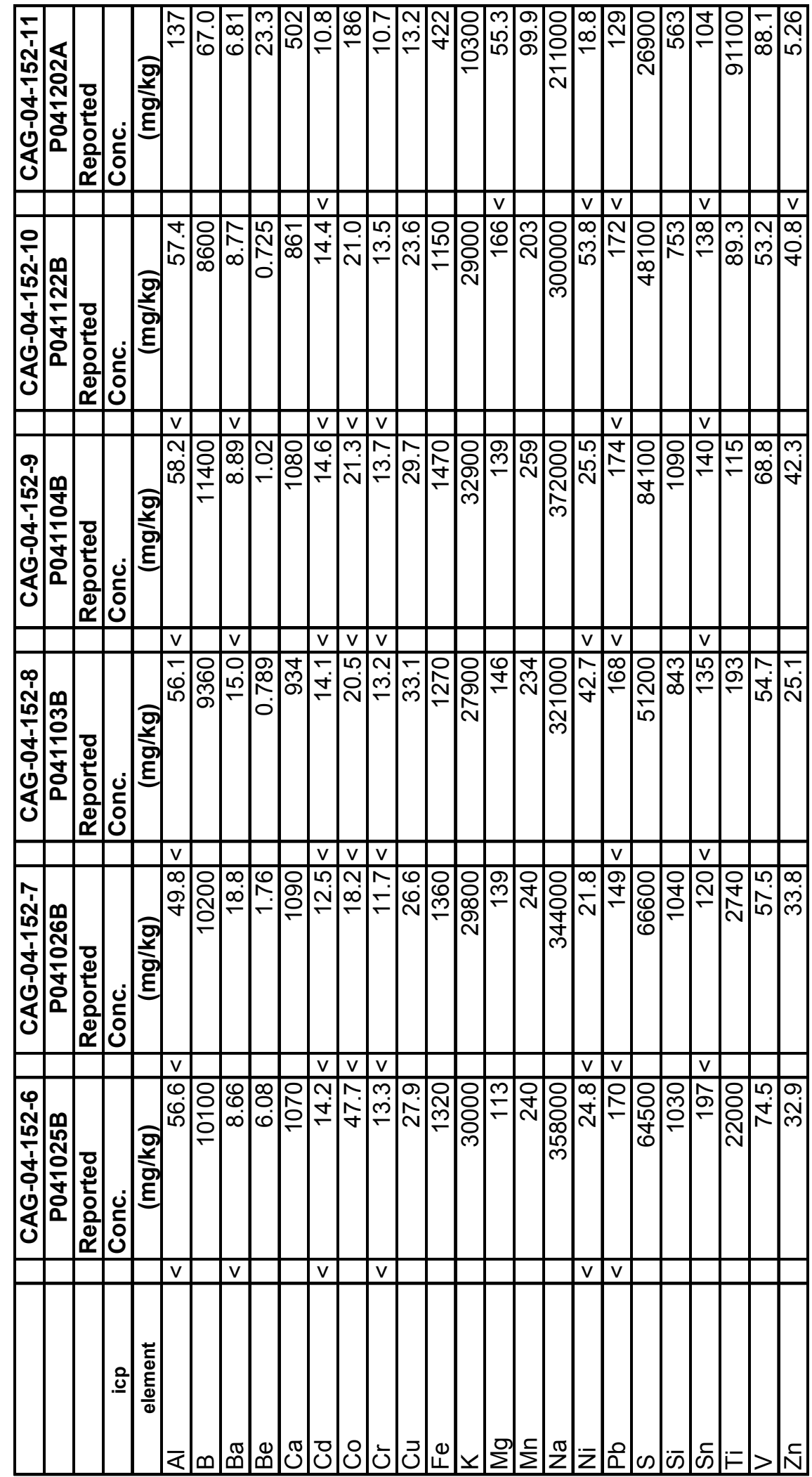


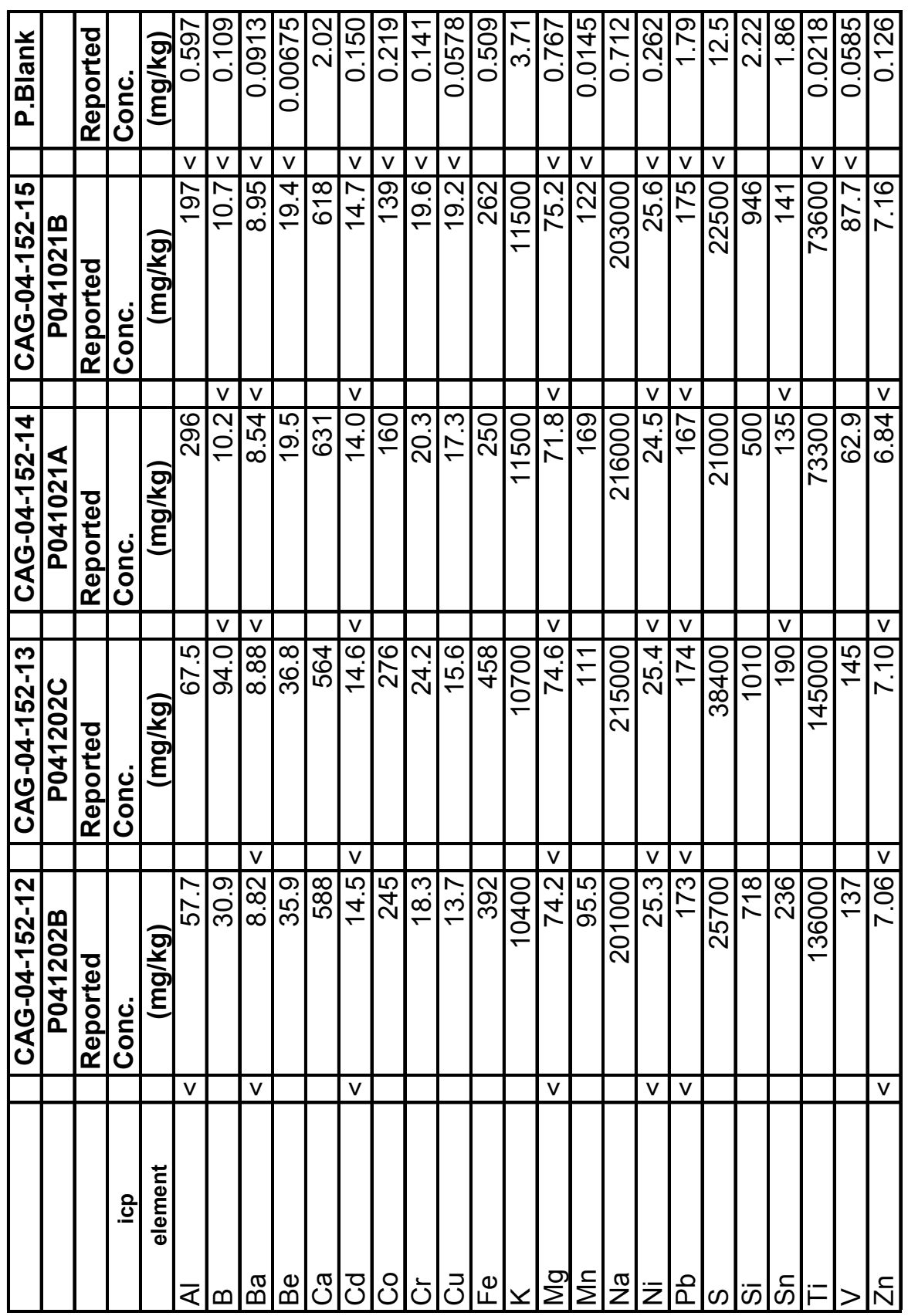



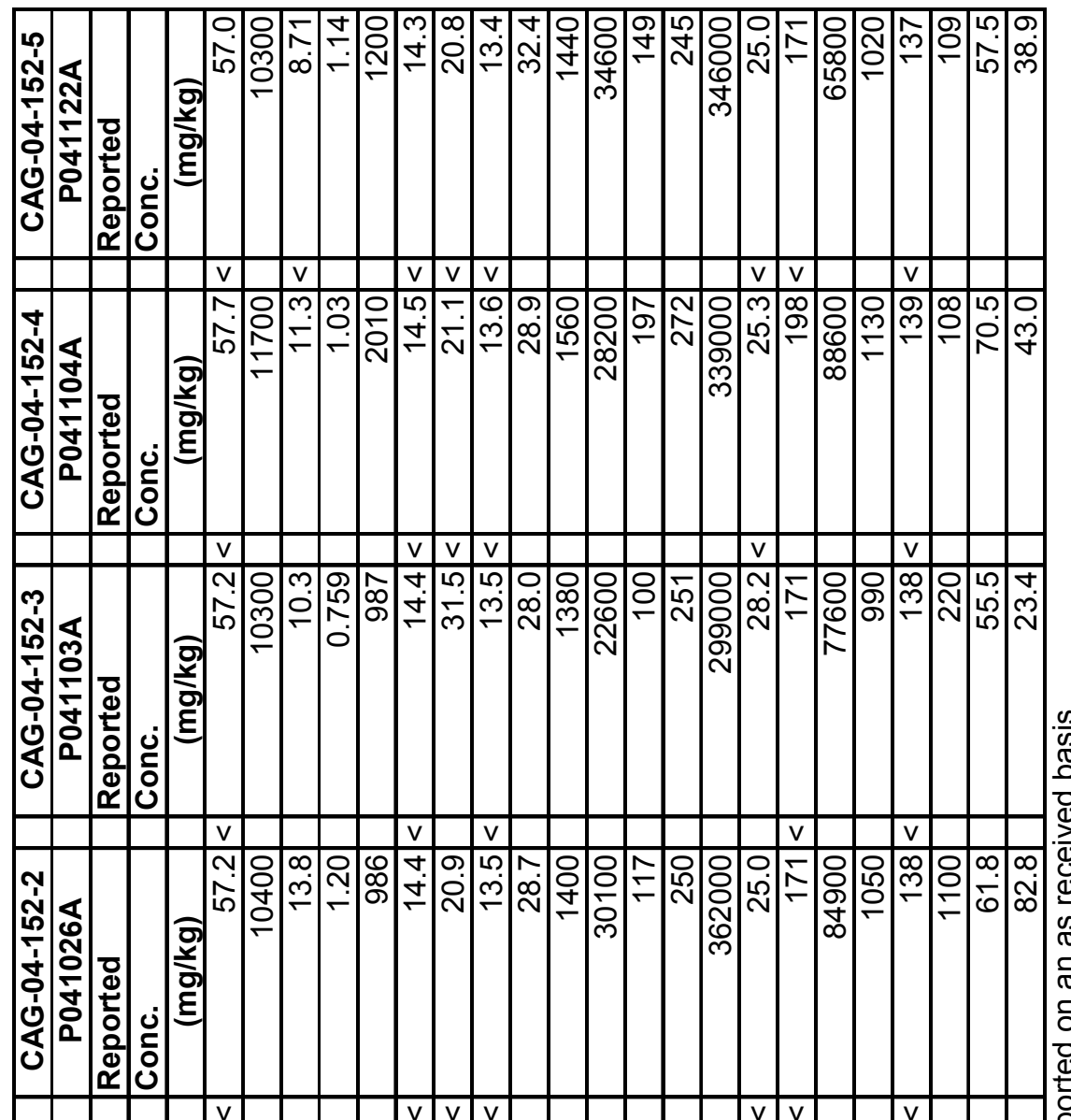

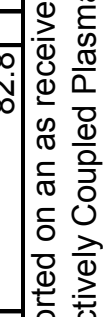
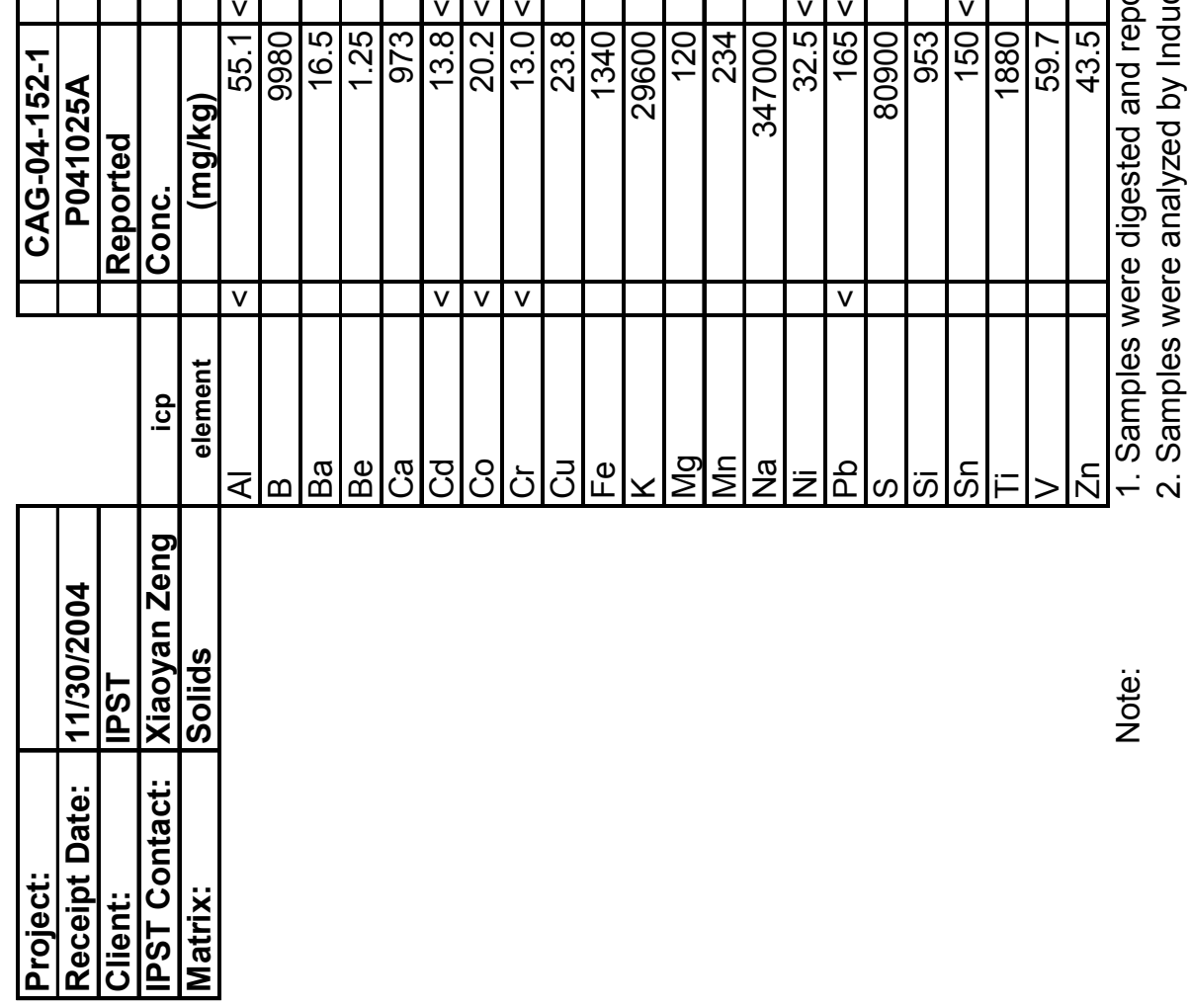


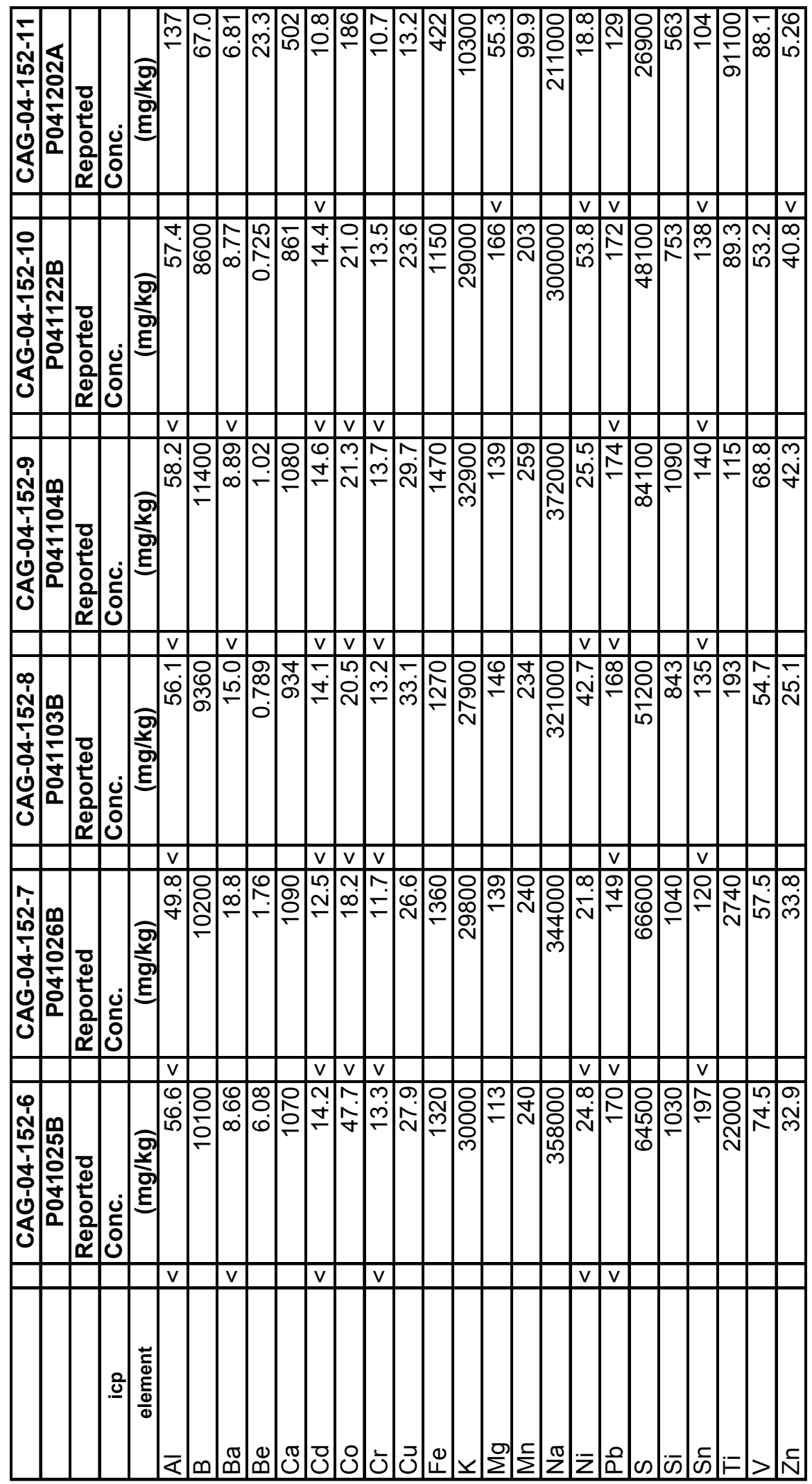




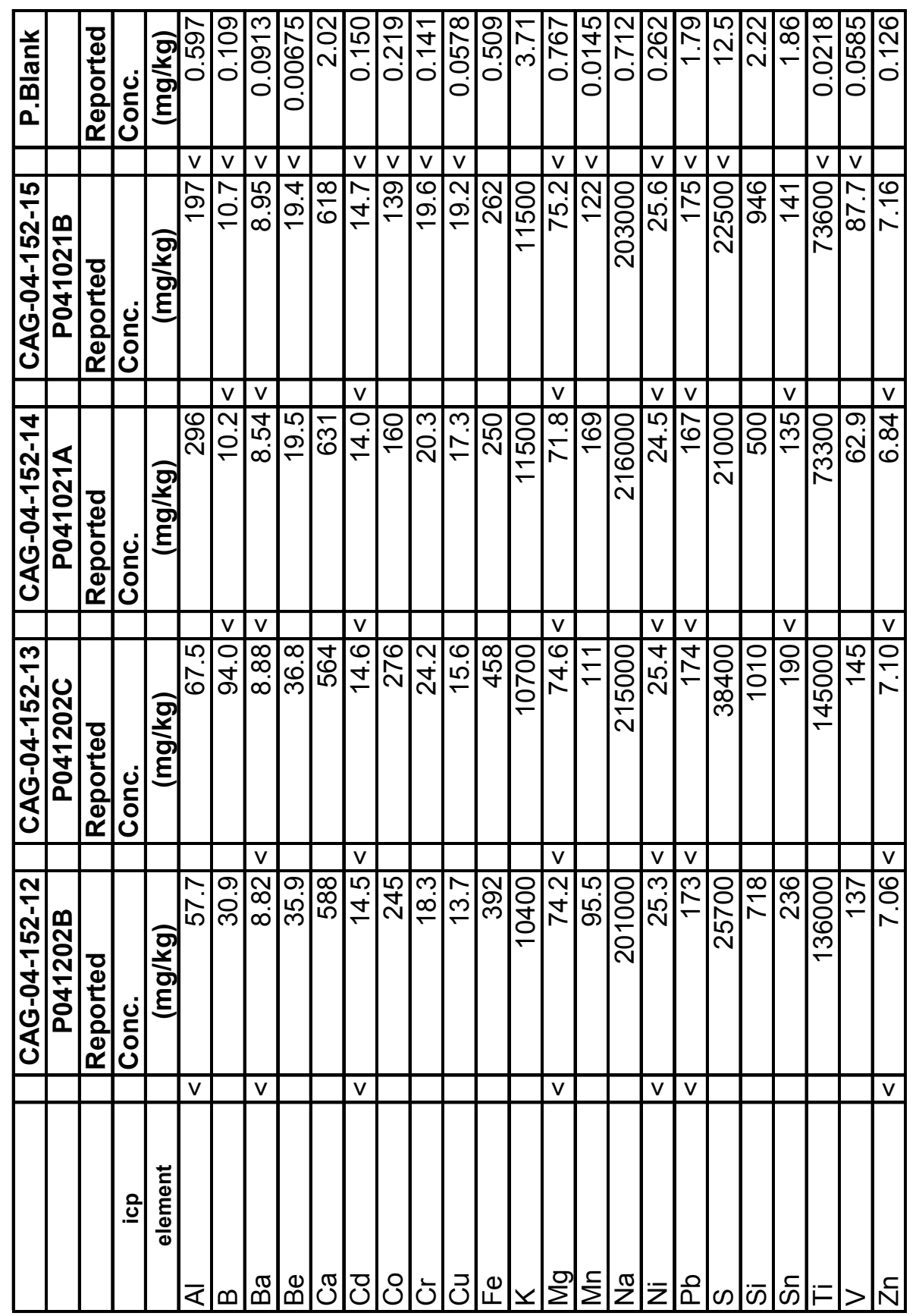




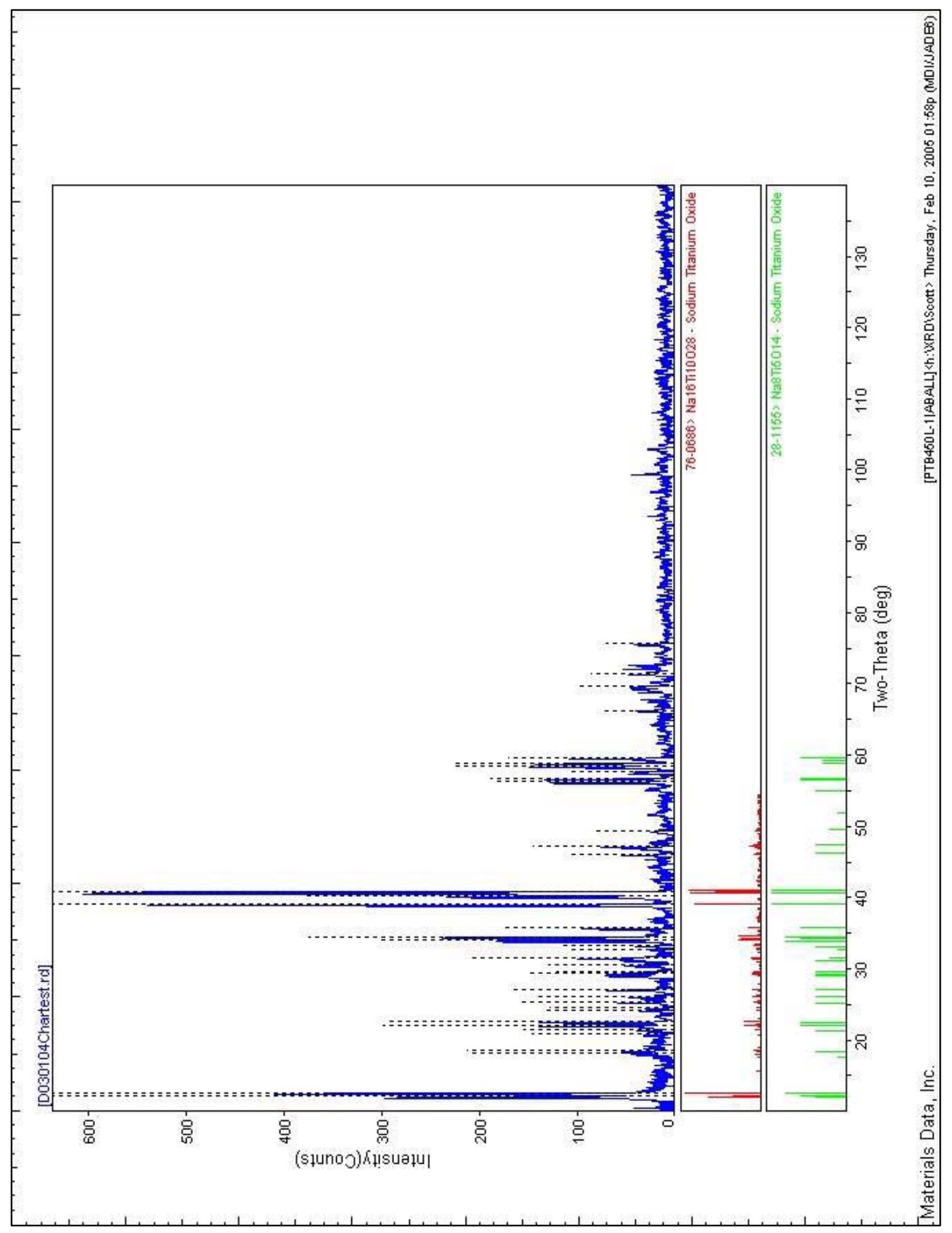




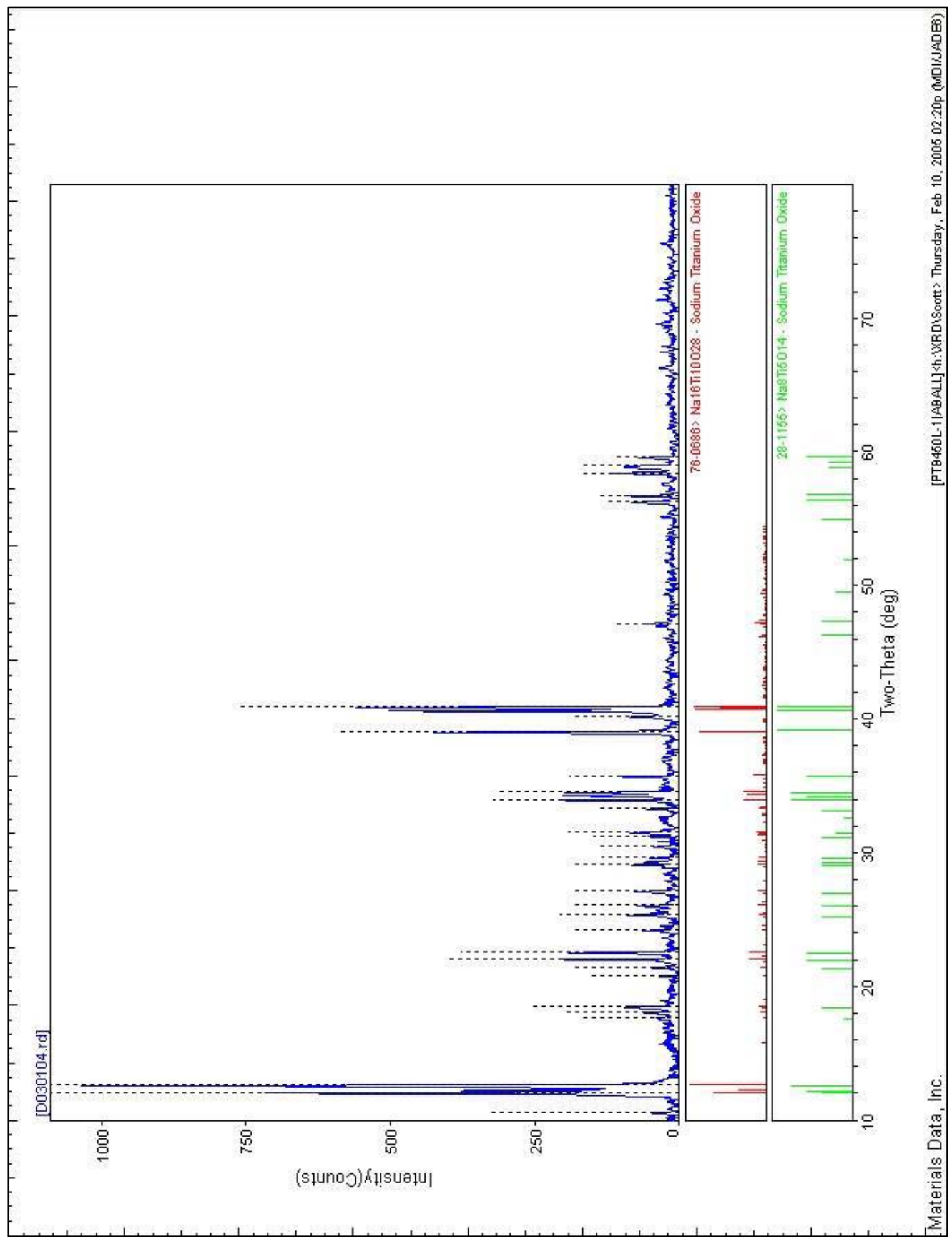




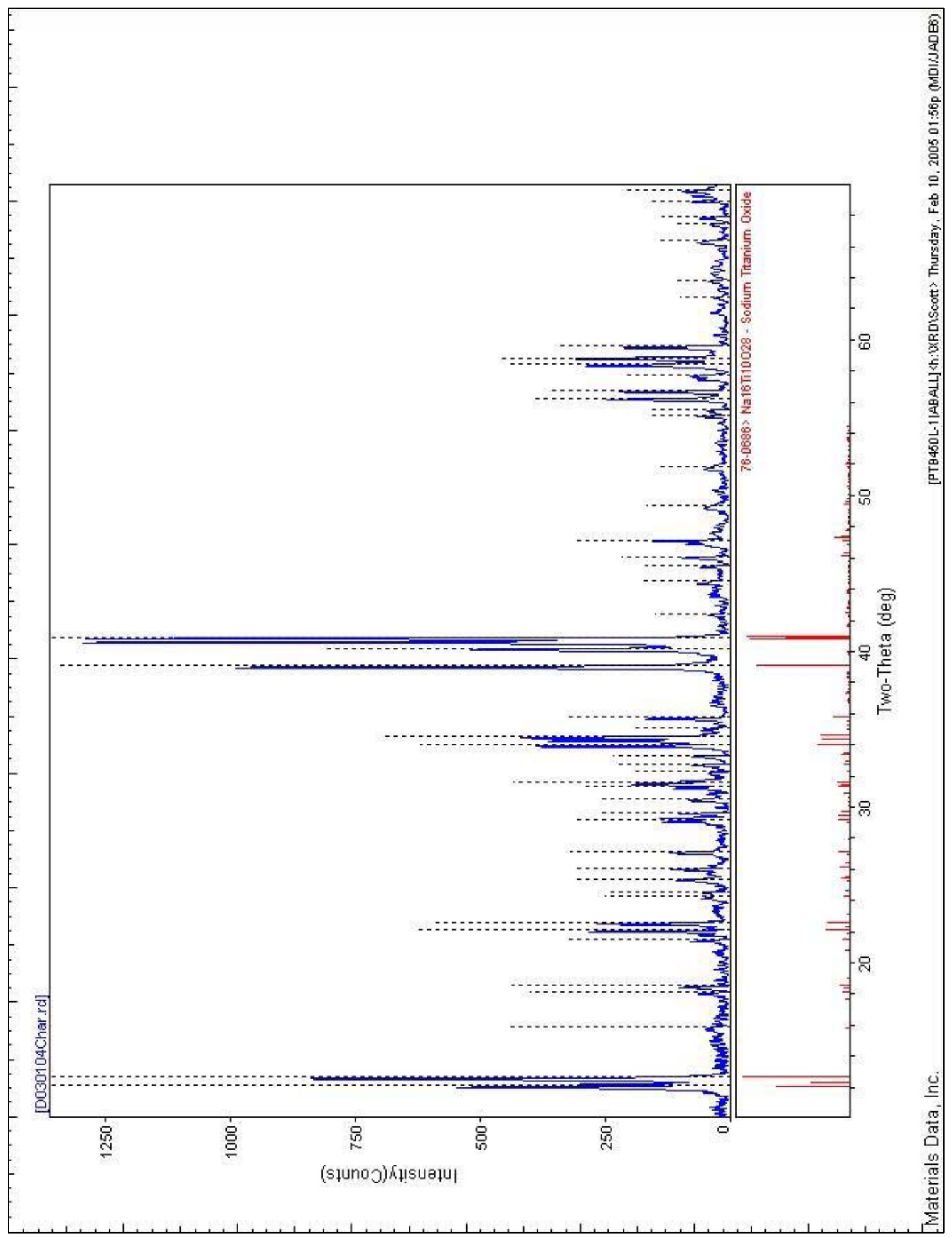




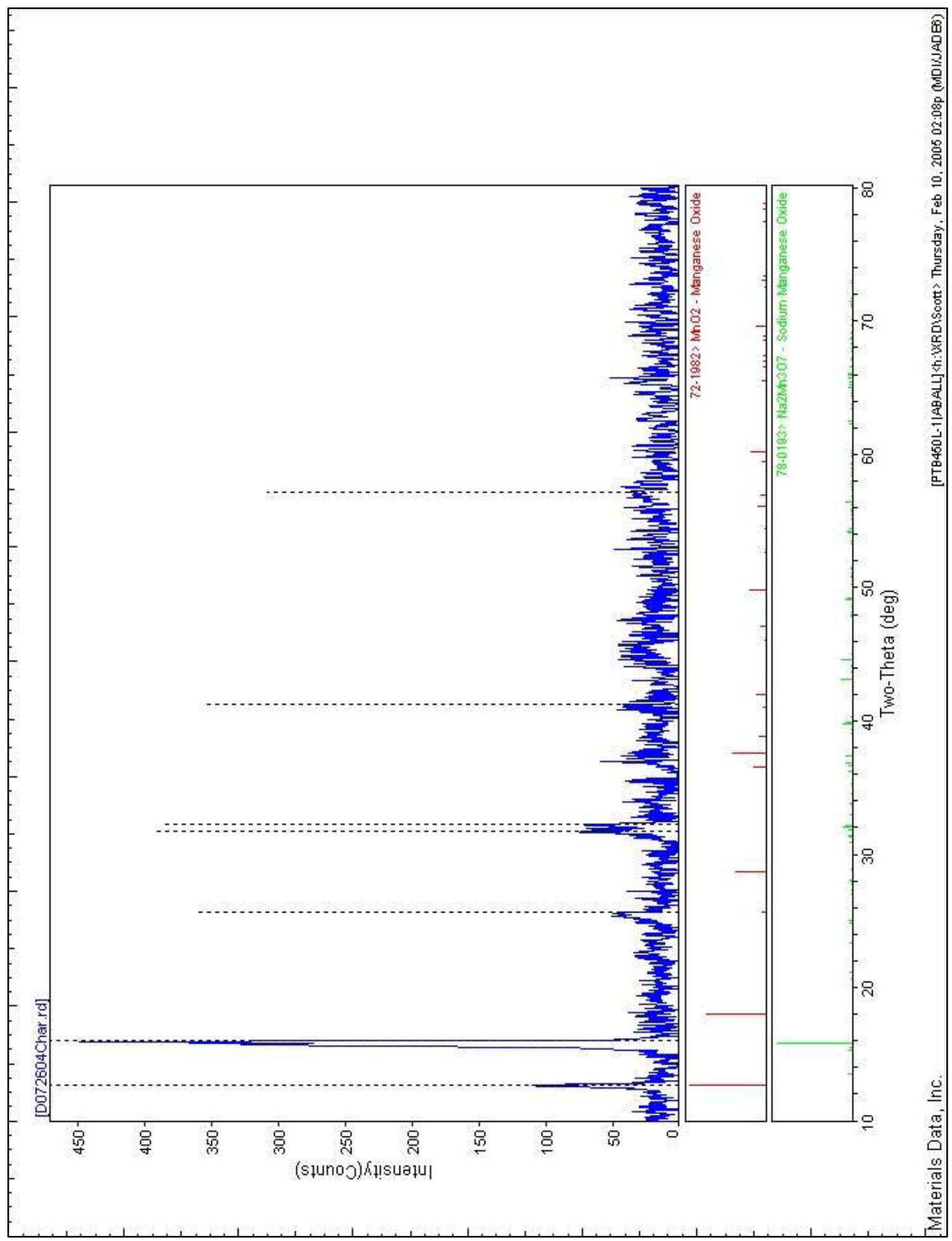




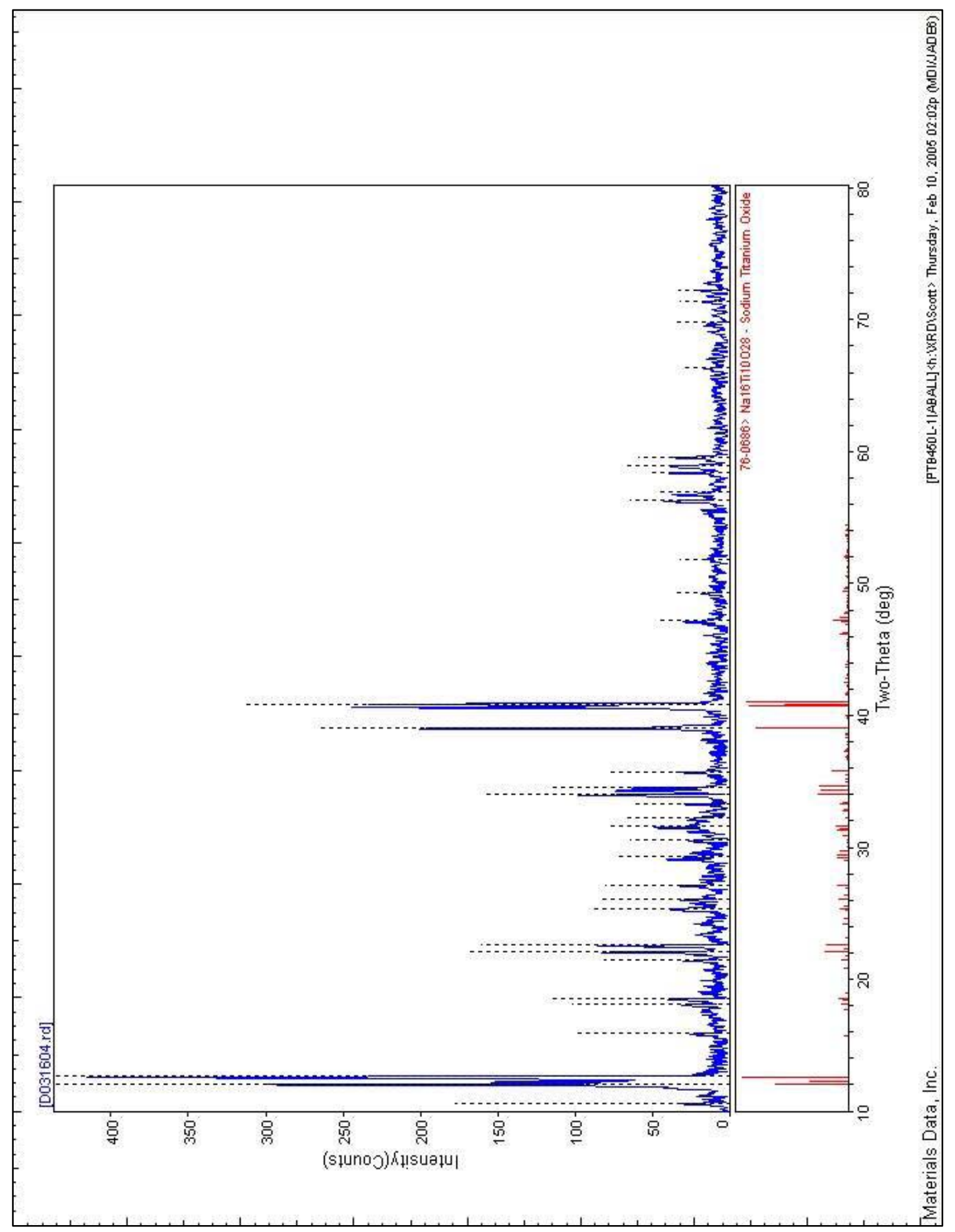




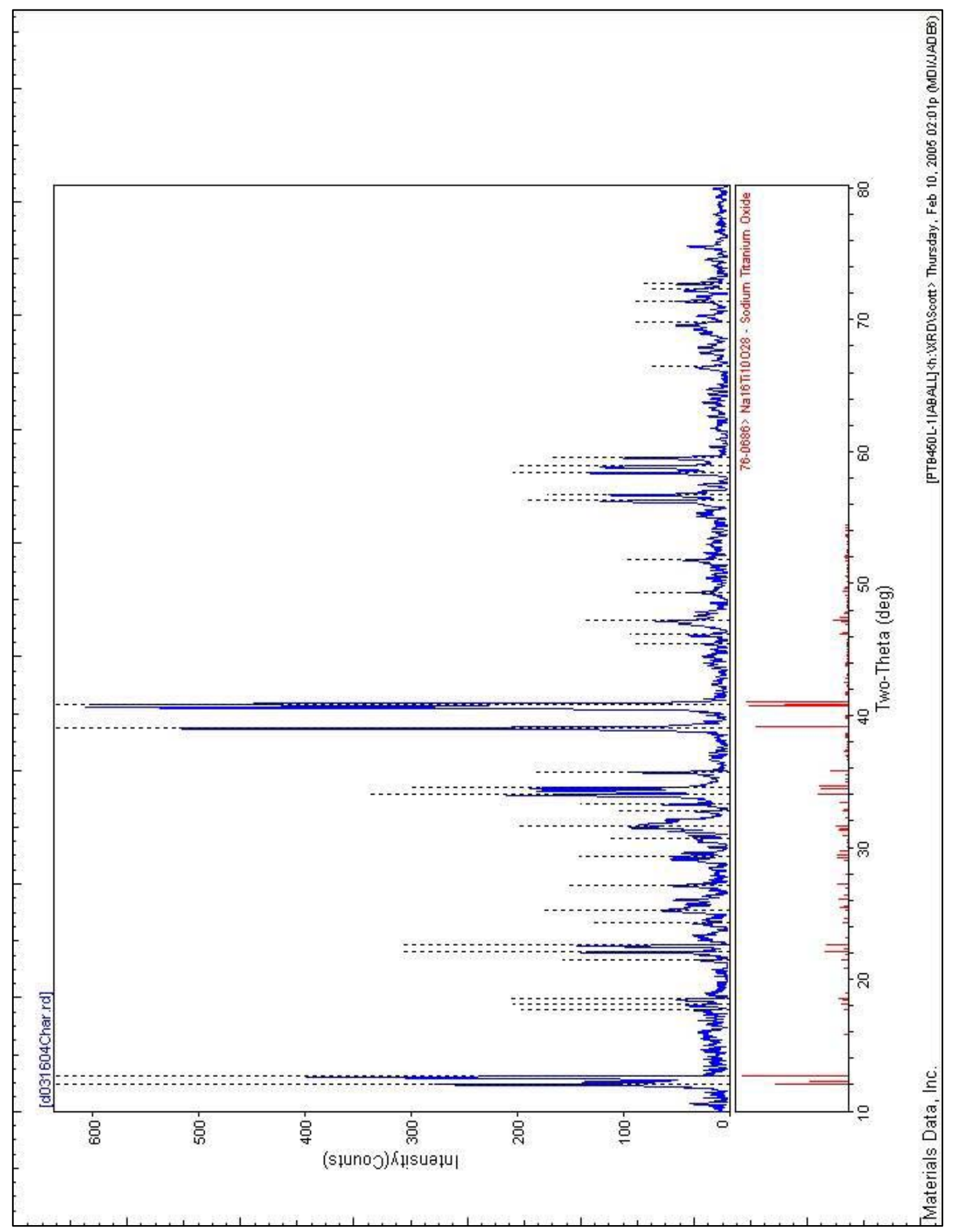




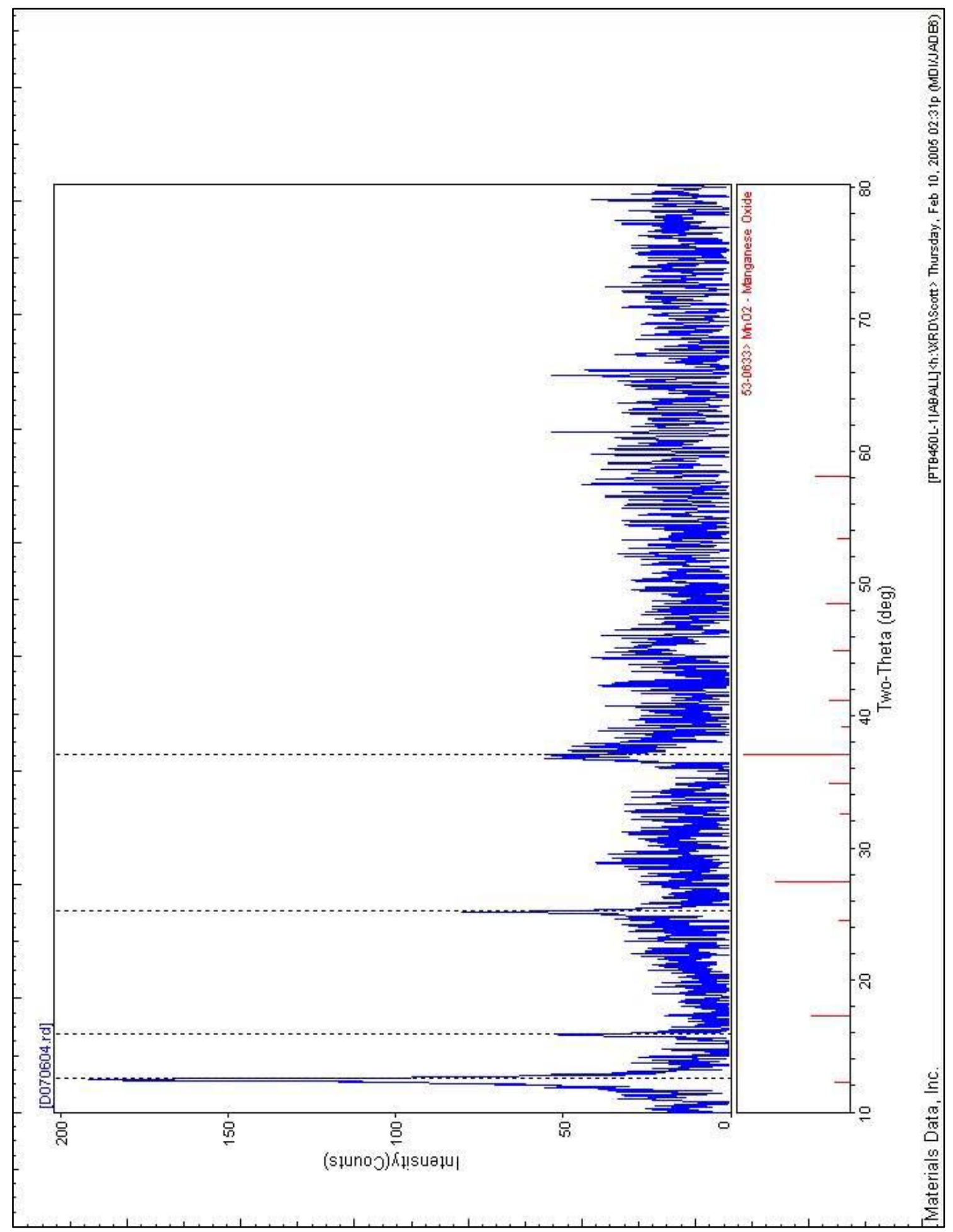




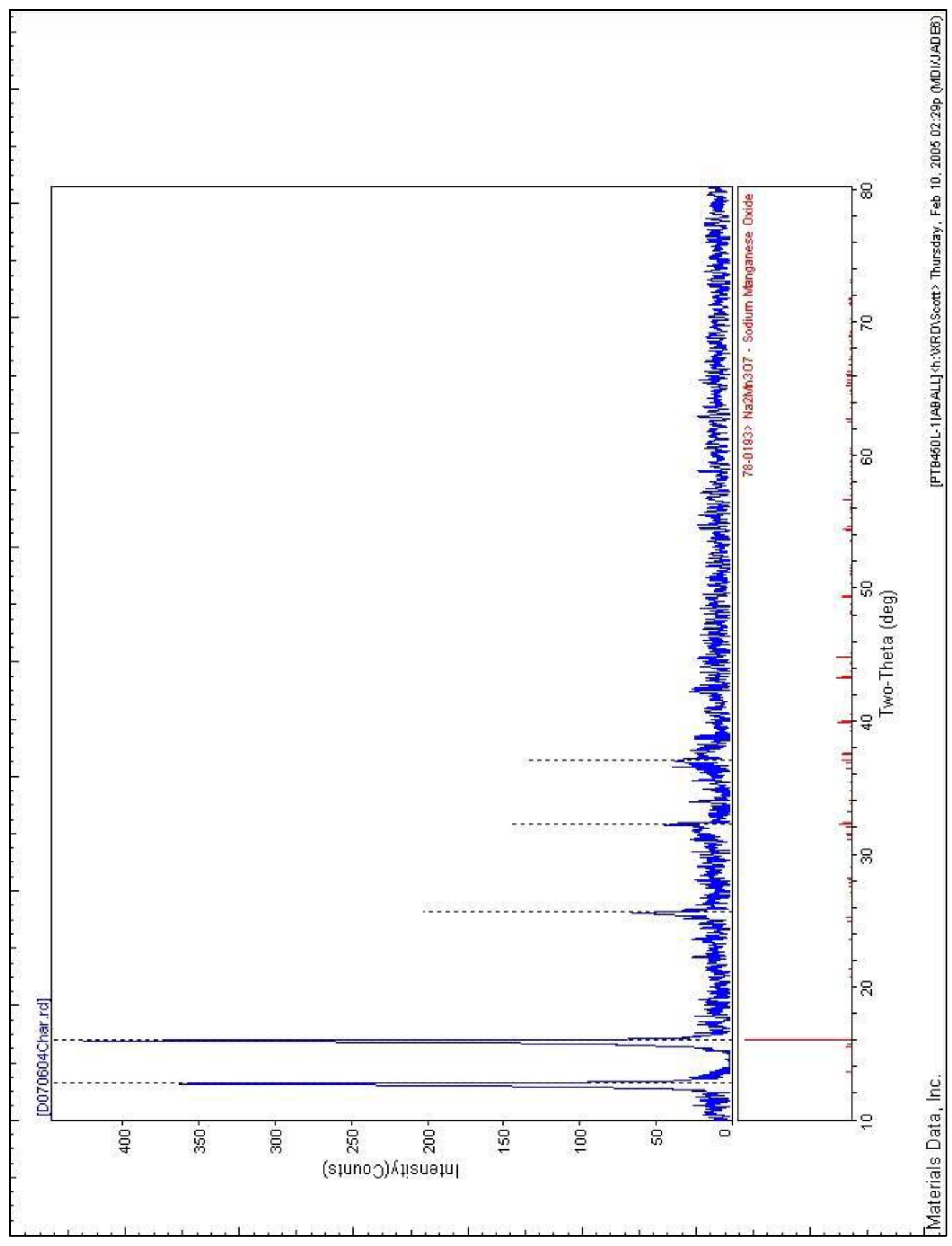




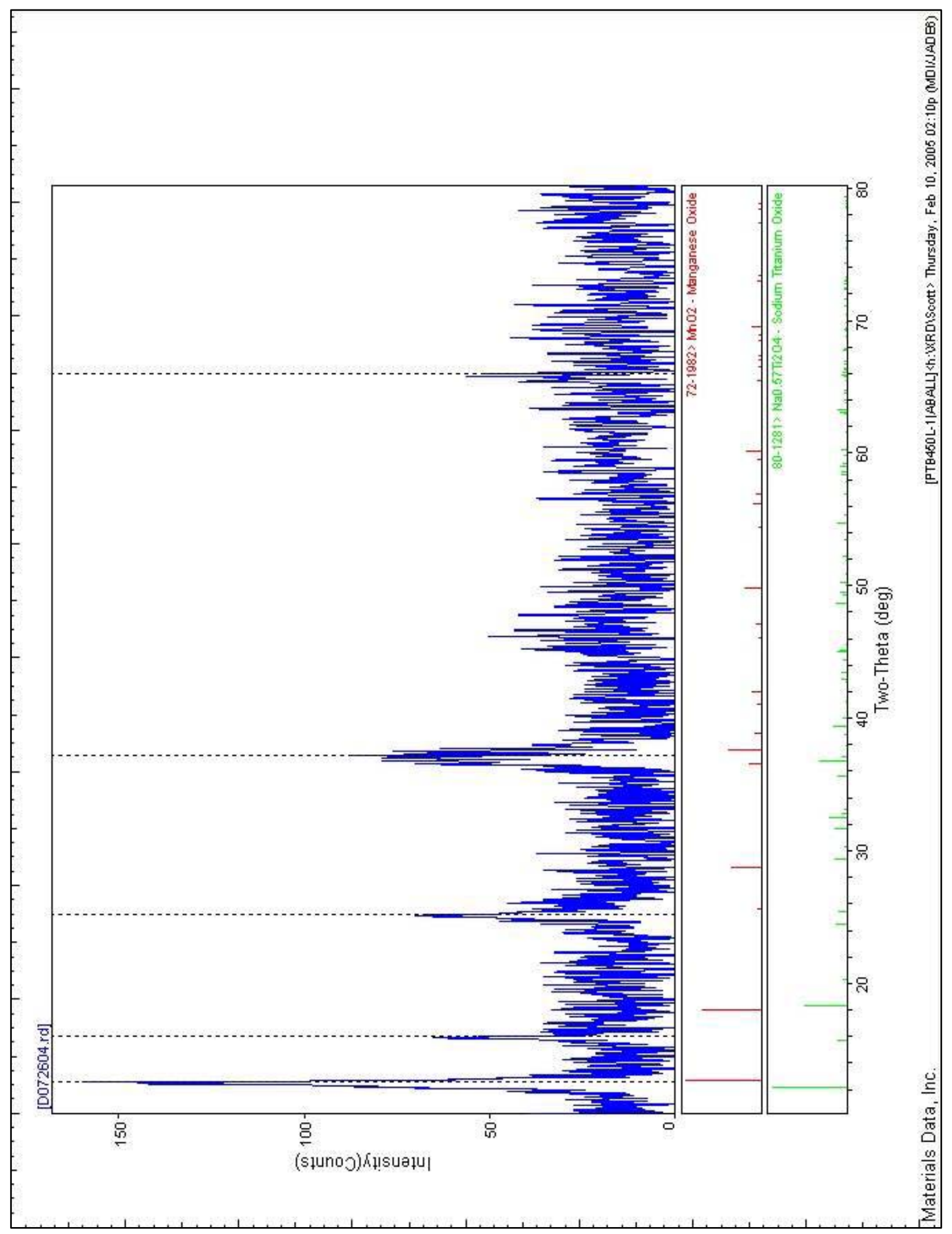




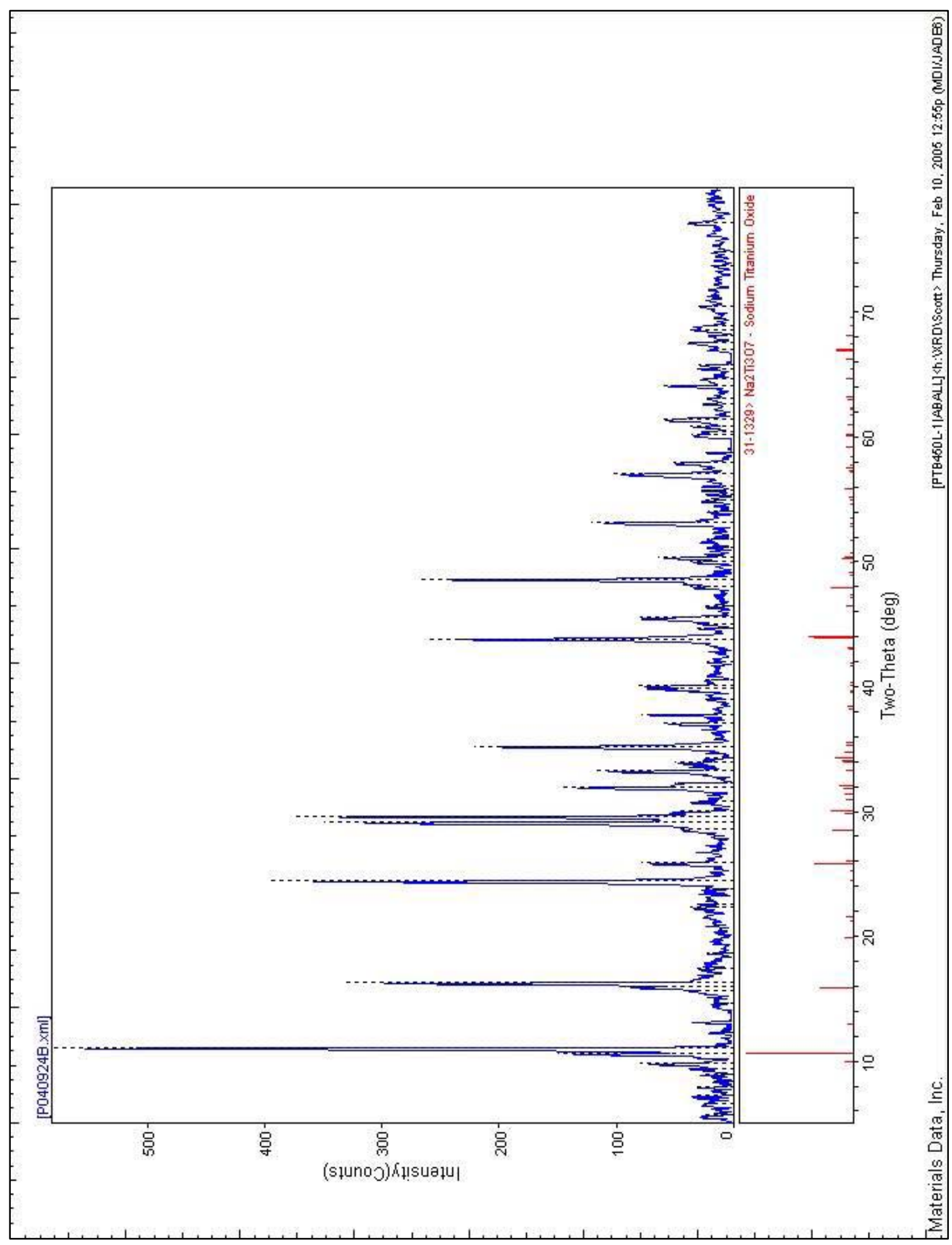




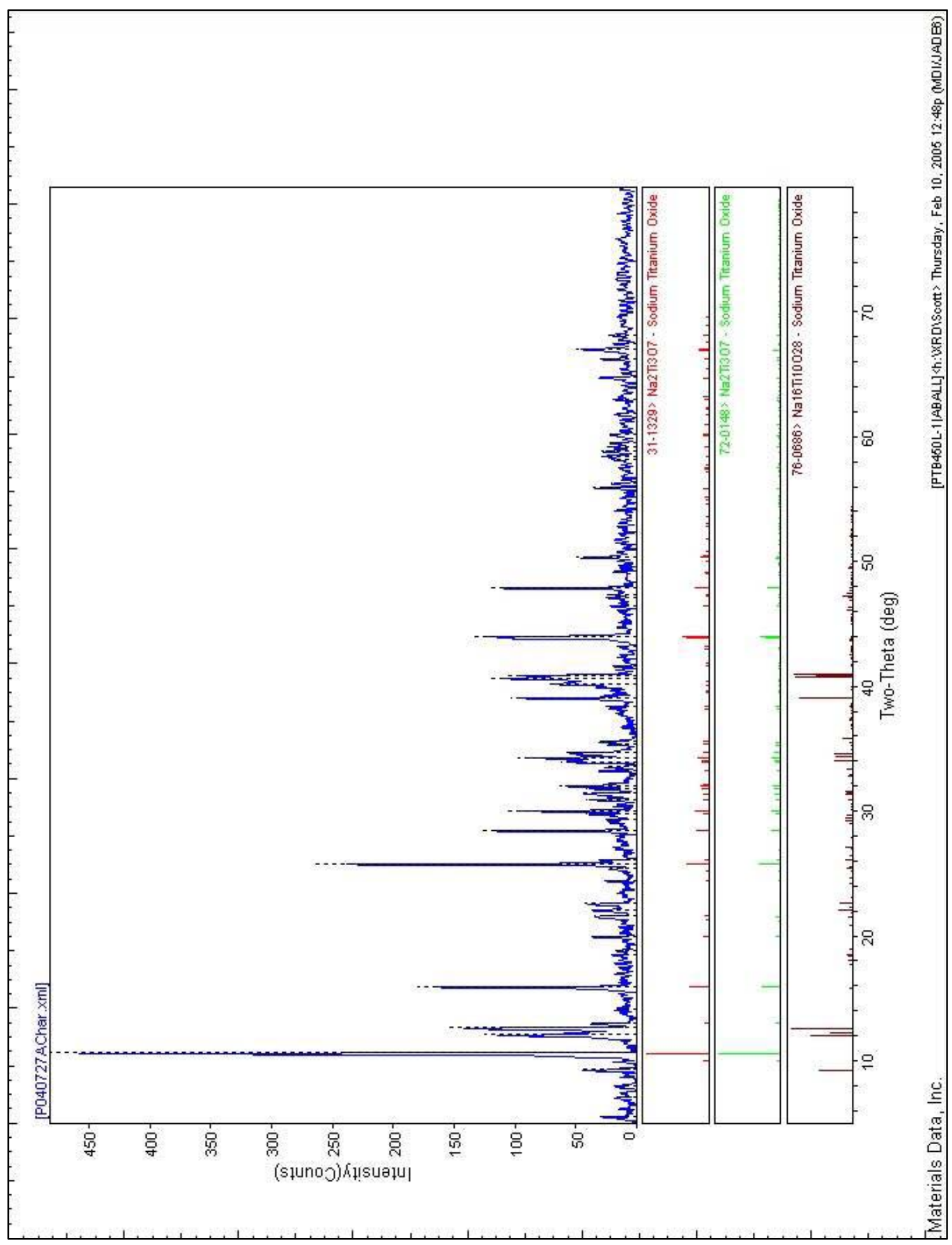




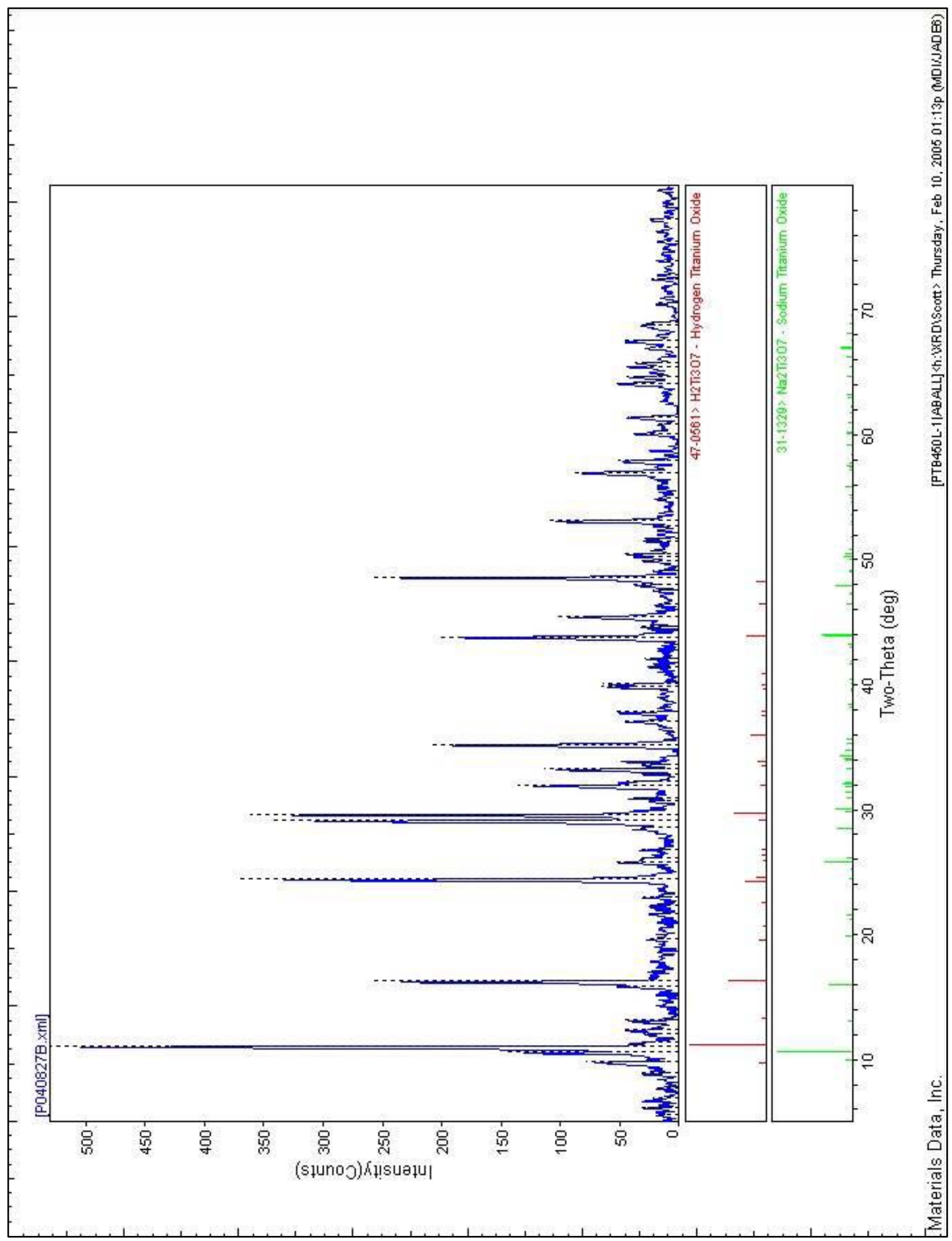




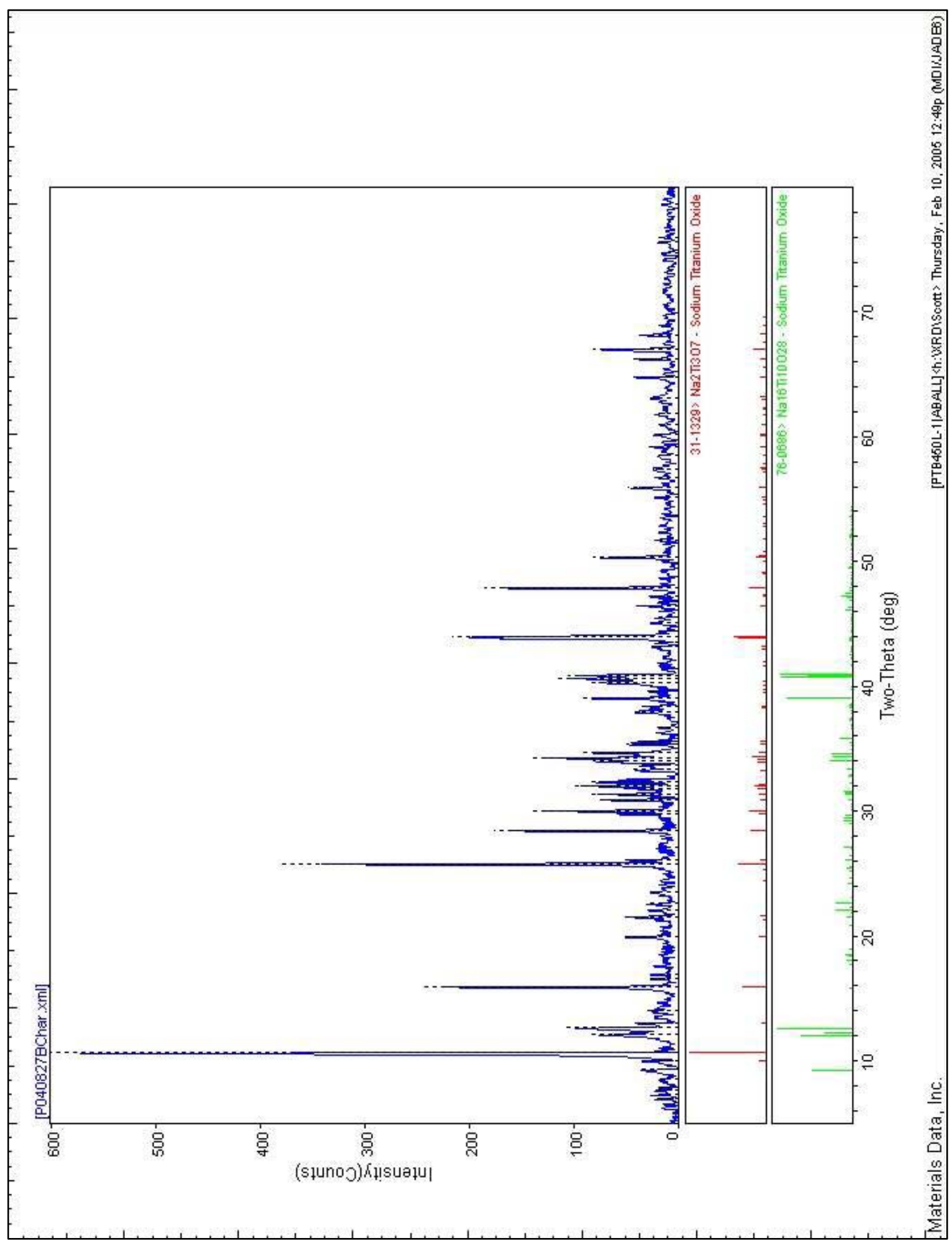




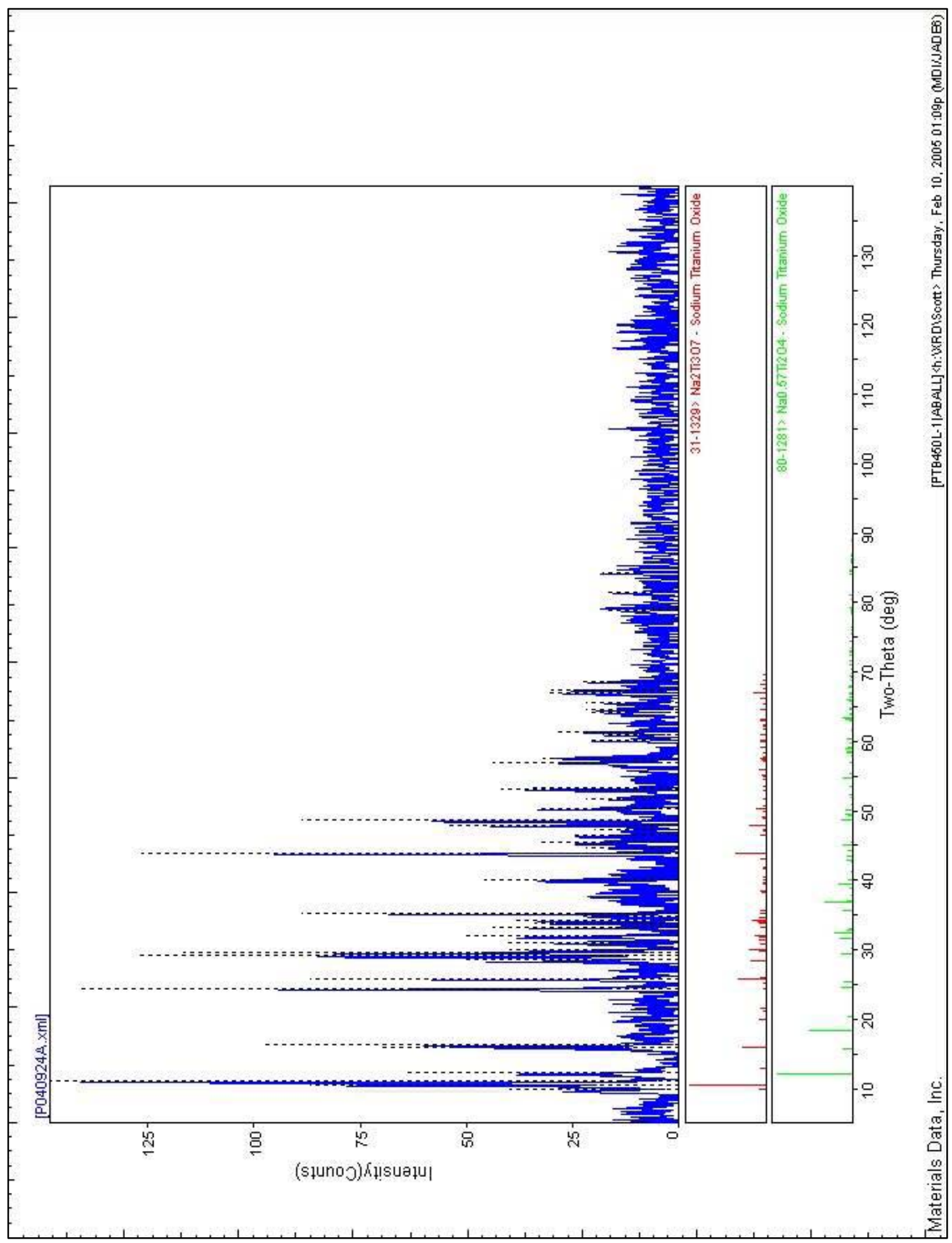




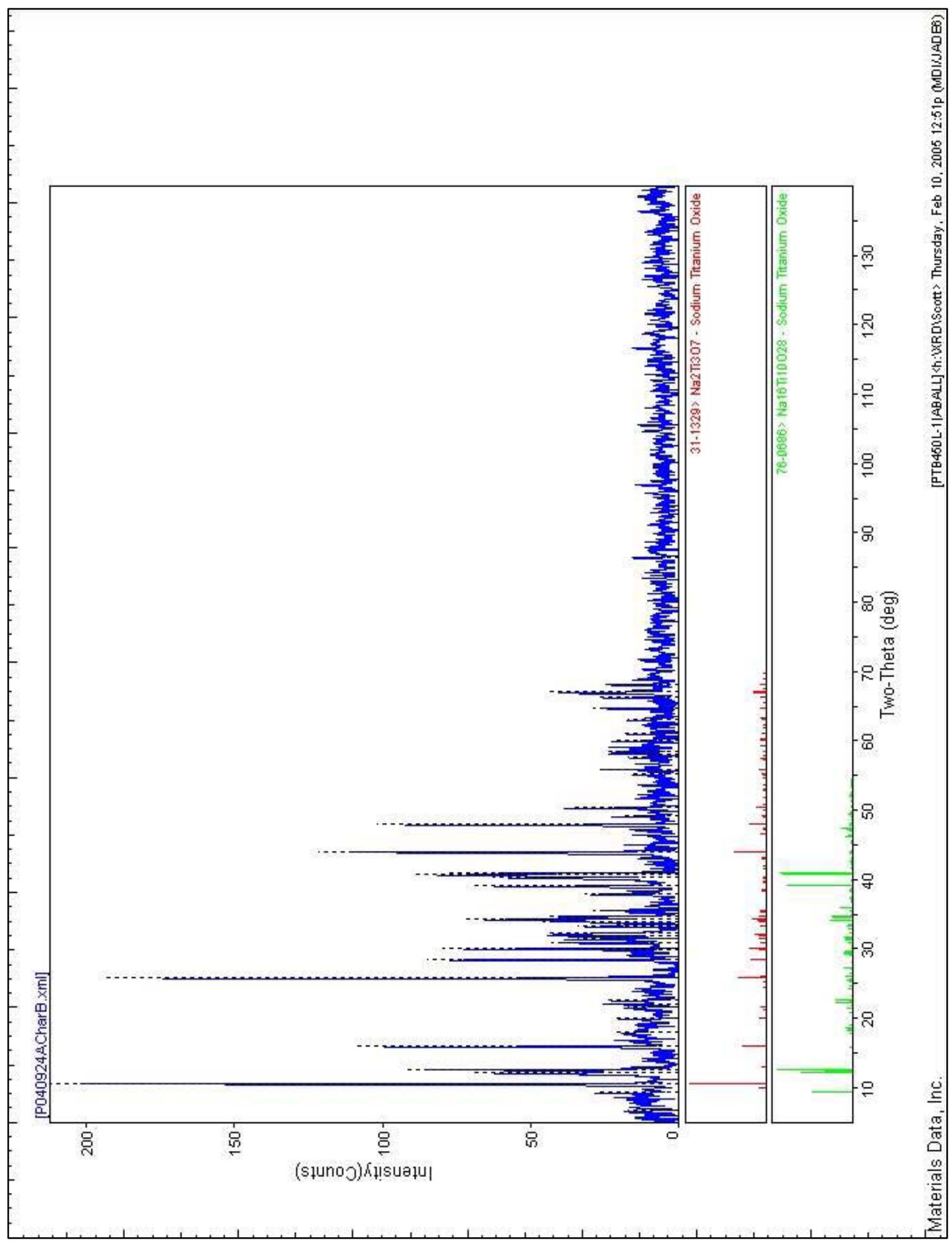




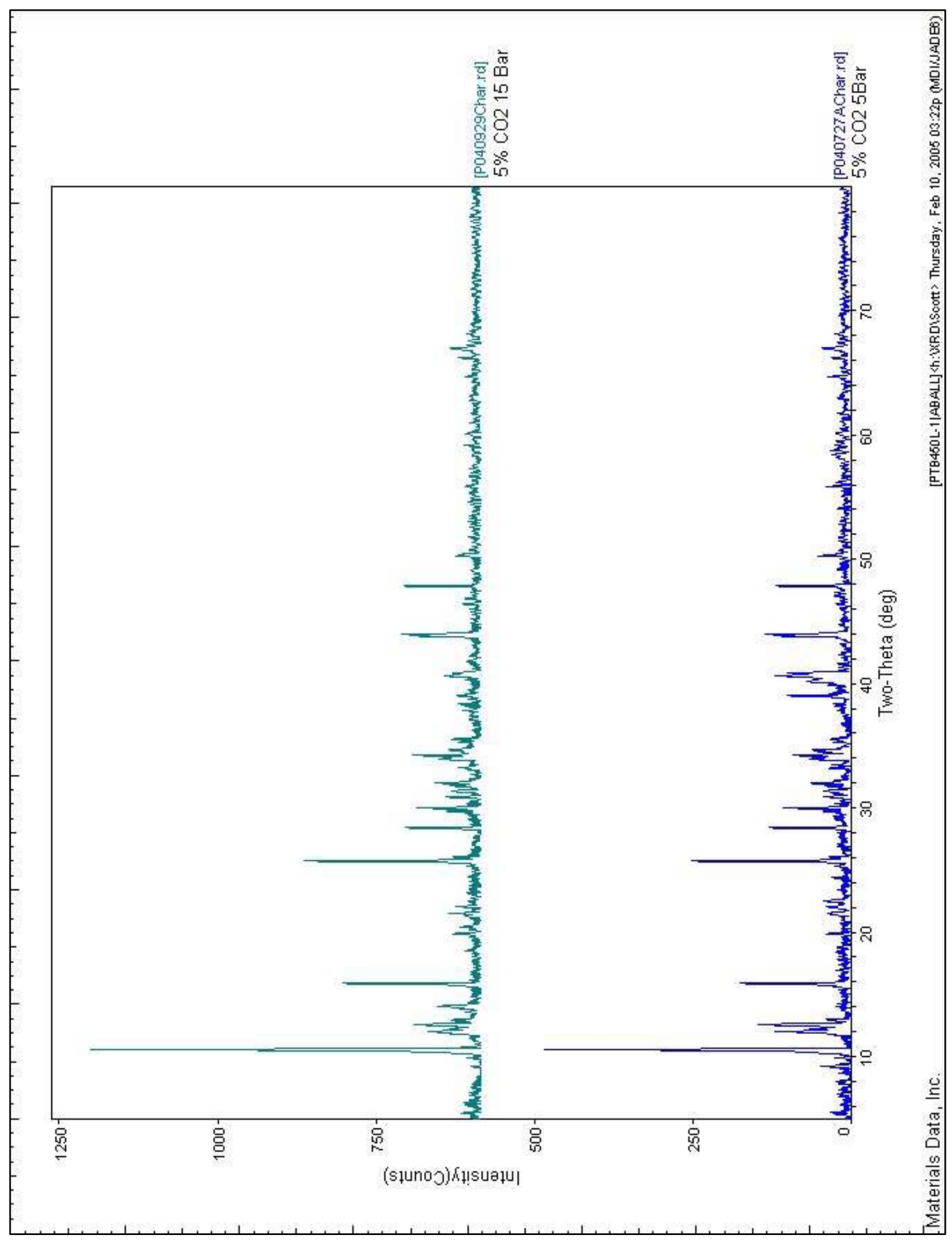




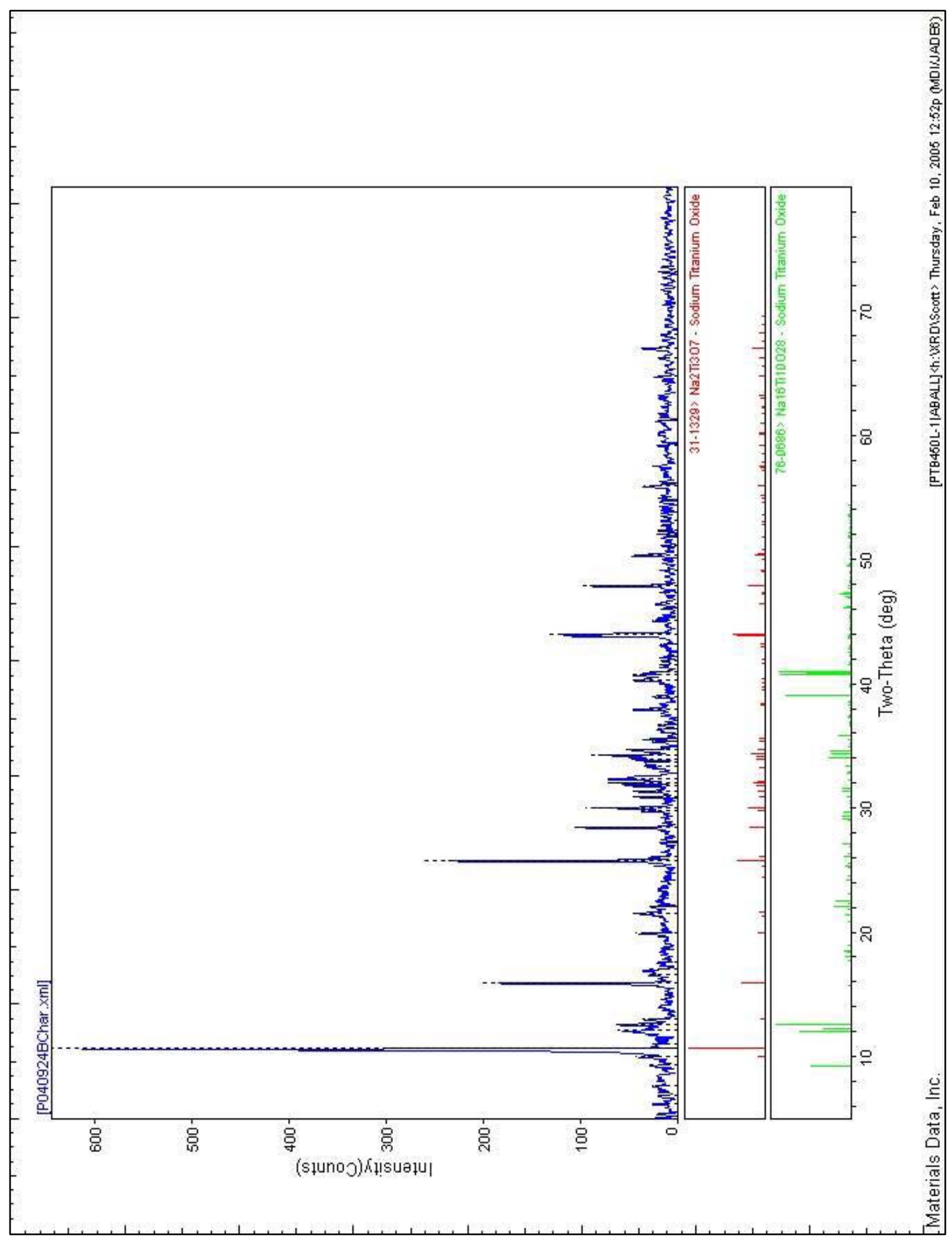




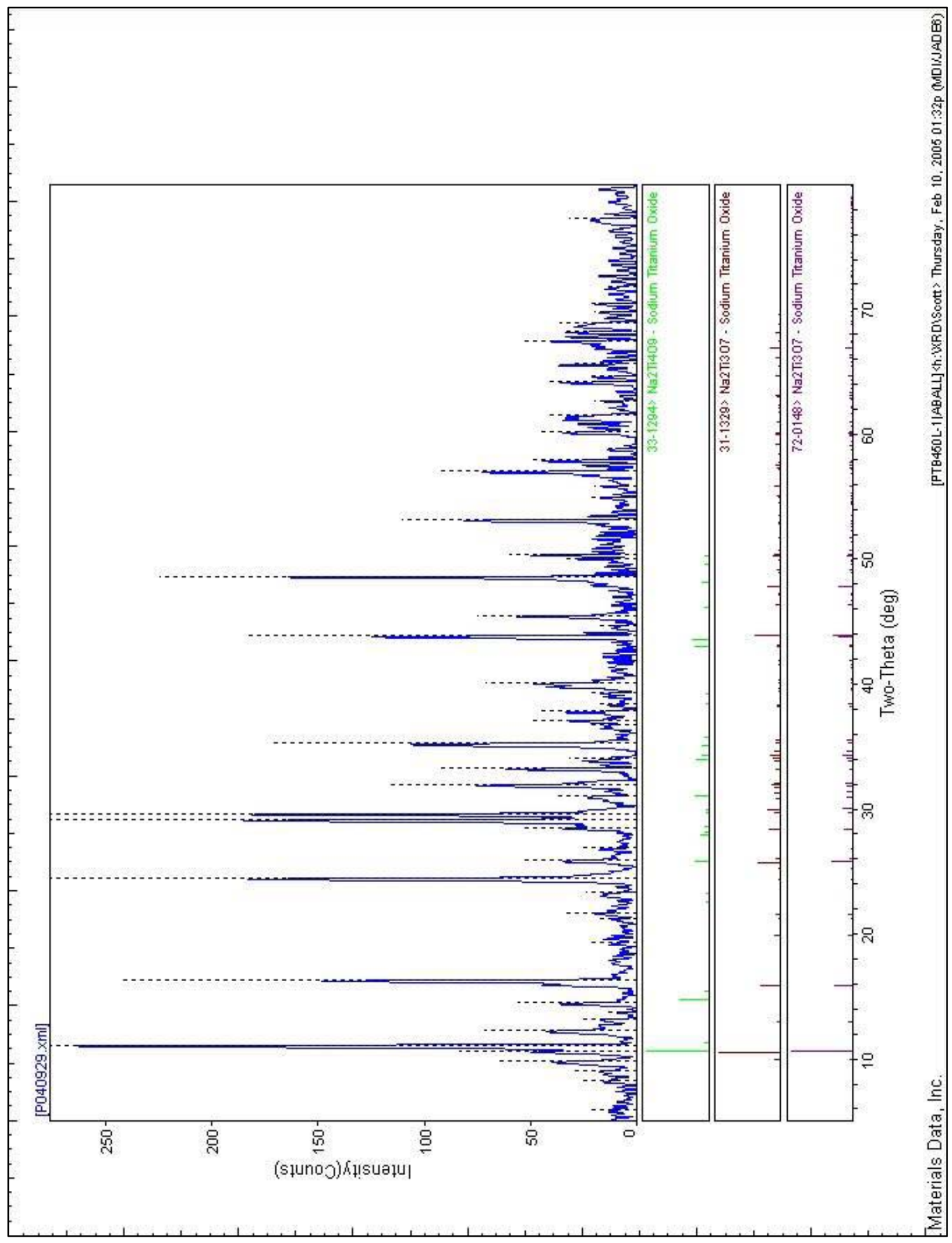




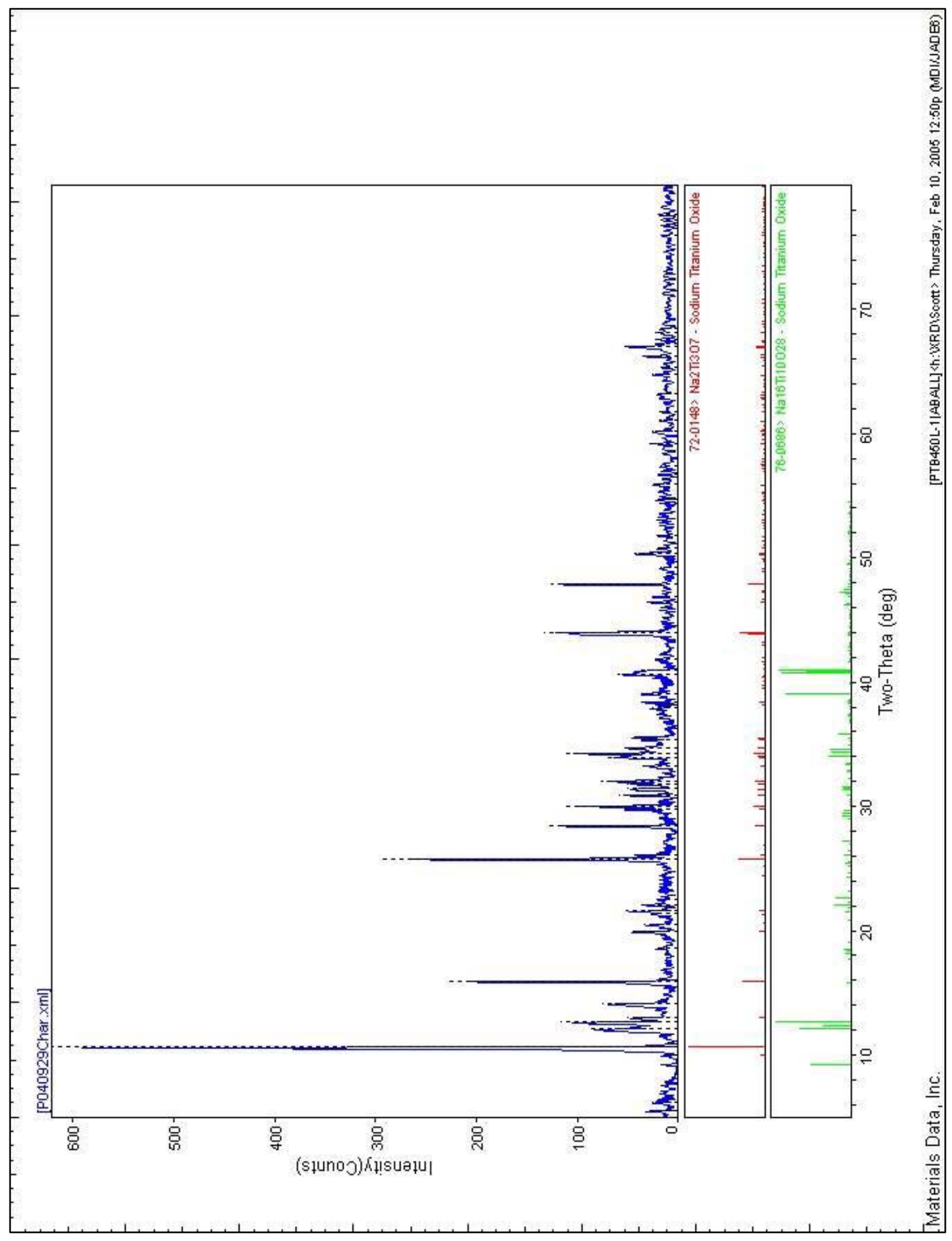




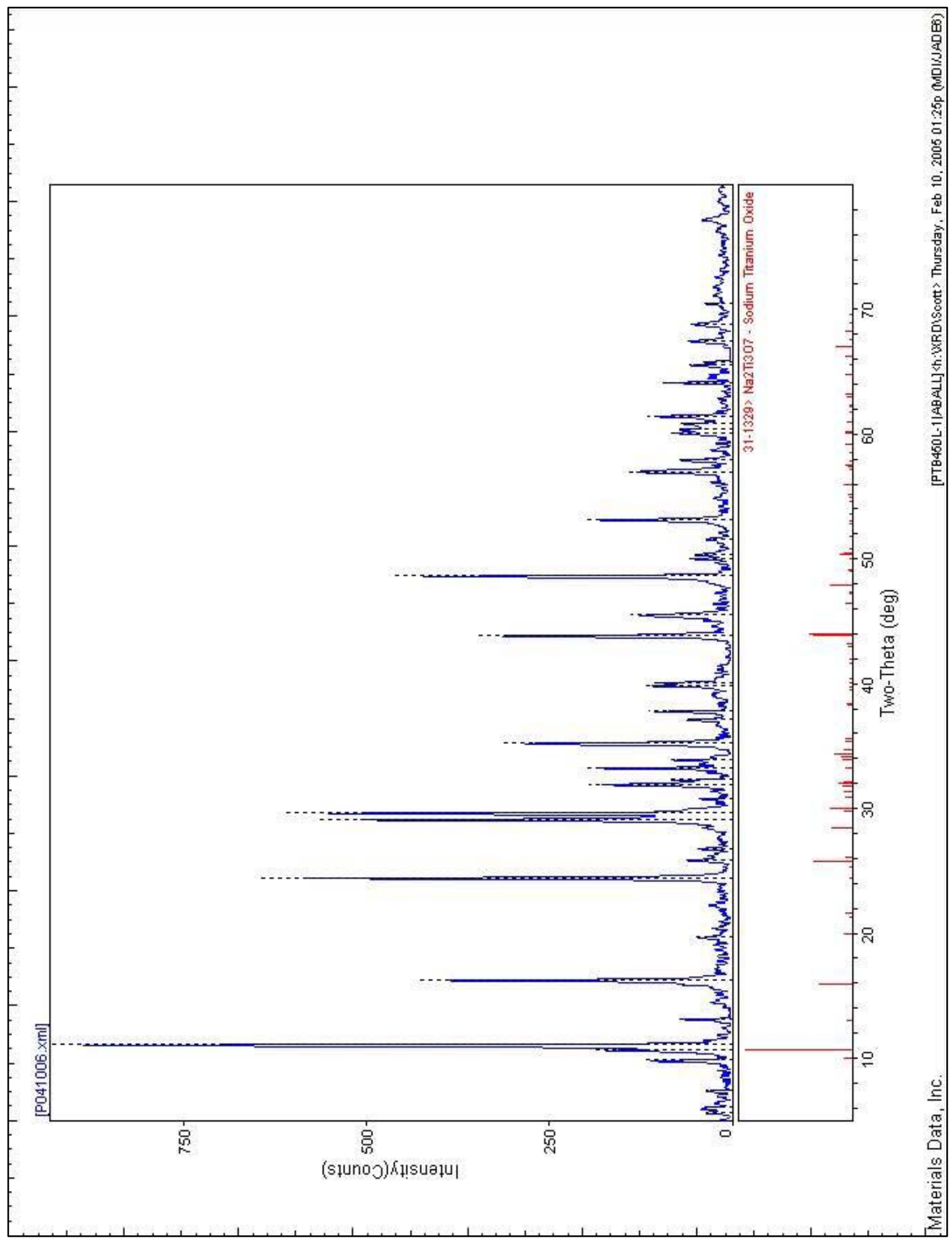




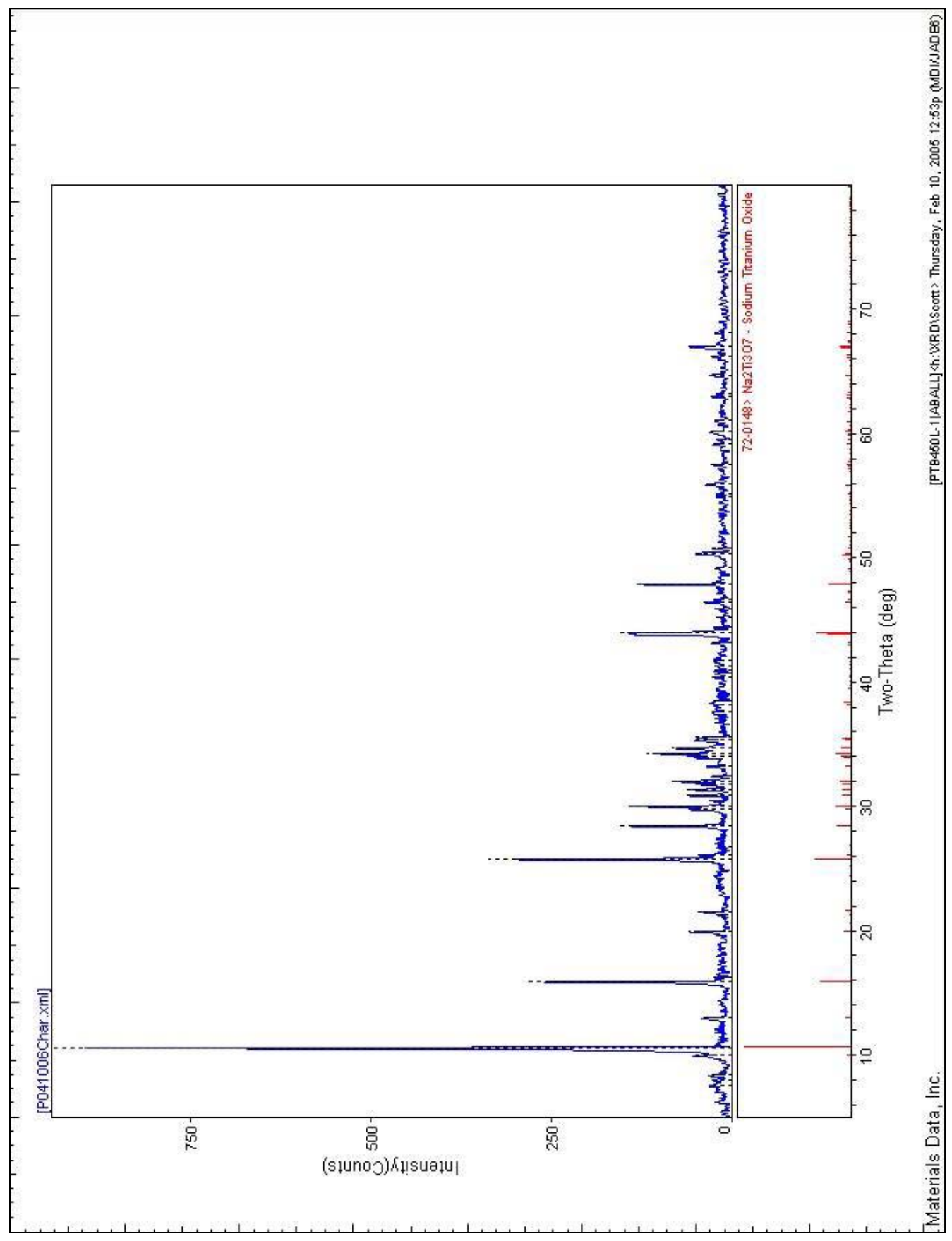




\section{LAST PAGE OF APPENDIX A}

\section{INTENTIONALLY BLANK}




\section{Project \\ DE-FC26-02NT41492}

\section{APPENDIX B}

\section{Jacobs Engineering Report}




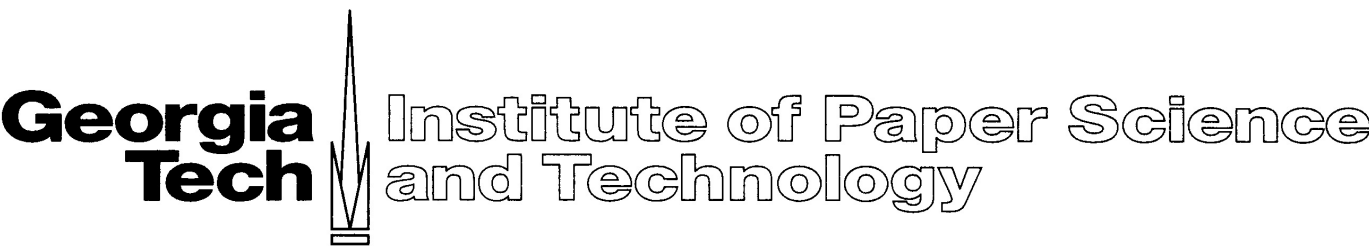 \\ Institute of Paper Science \& Technology at the \\ Georgia Institute of Technology \\ Atlanta, Georgia}

\section{Causticizing for \\ Black Liquor Gasification - Mill Integration Study}

Final Report

Jacobs Job No. 16BD7500

February 26, 2007 


\section{TABLE OF CONTENTS}

Section

Description

$\underline{\text { Page }}$

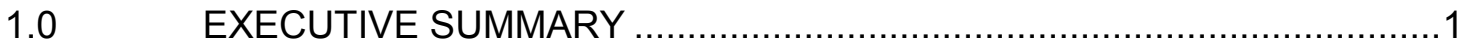

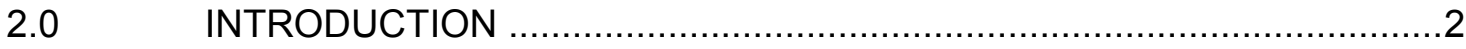

3.0 DESIGN BASIS AND MILL CHARACTERIZATION................................

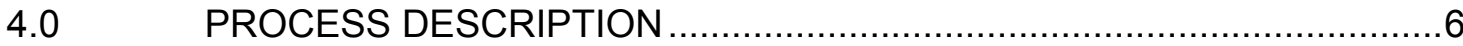

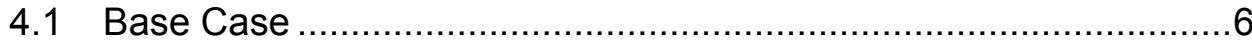

4.2 Borate Case (Auto Causticizing) ............................................. 6

4.3 Titanate Case (Direct Causticizing) ..........................................6

4.4 Water Balance ....................................................................13

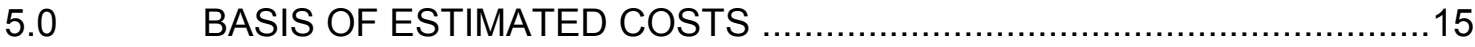

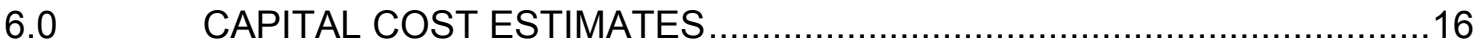

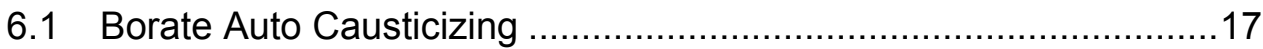

6.2 Titanate Direct Causticizing ......................................................20

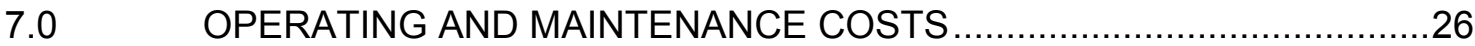

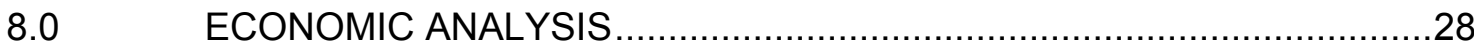

8.1 Approach and Assumptions .................................................. 28

8.2 Economic Analysis Results ................................................. 30

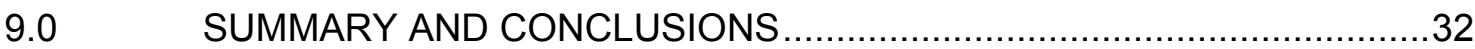

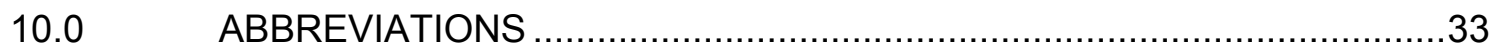

11.0 APPENDICES

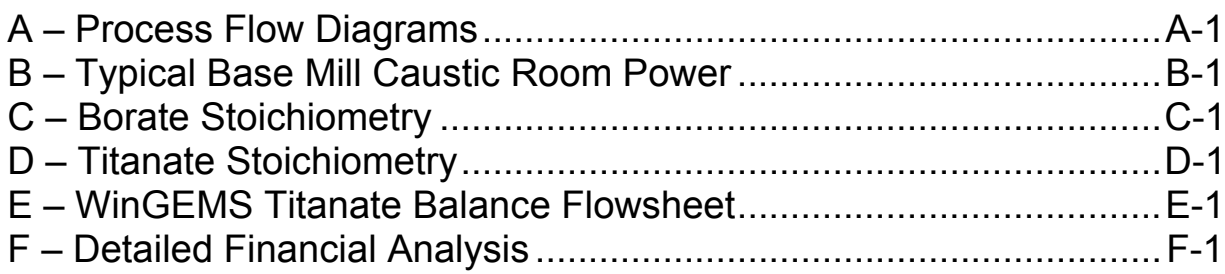




\subsection{EXECUTIVE SUMMARY}

Jacobs has prepared a mill integration study for the Institute of Paper Science \& Technology (IPST) at Georgia Tech for in situ causticizing during black liquor gasification. Two in situ causticizing options are compared to the base case of high temperature black liquor gasification (HTBLG) with conventional causticizing. Borate is an auto-causticizing agent that can replace up to $20 \%$ of the conventional lime cycle. Titanate remains as a suspended solid throughout the process and can replace $100 \%$ of the conventional lime cycle.

The reference mill basis is identical to that used in the Larson Study from October, 2003 entitled "A Cost-Benefit Assessment of Biomass Gasification Power Generation in the Pulp and Paper Industry"1. The base case for this mill integration study is HTBLG with conventional causticizing since the borate and titanate only perform successfully under the high temperature gasification conditions.

The base case $+/-30 \%$ total installed cost estimate is $\$ 1.2 \mathrm{MM}$ and includes oxygen enrichment, a new kiln burner system, and new refractory brick to increase the kiln capacity.

The borate option $+/-30 \%$ total installed cost estimate is $\$ 170,000$ and includes a borate mix down system for adding borate to the green liquor prior to slaking.

The titanate option $+/-30 \%$ total installed cost estimate is $\$ 31.6 \mathrm{MM}$ and includes a full 3-stage leaching system and non-process elements (NPE) acid leaching purge system to replace the conventional lime cycle process. Concentrator upgrades are also required to handle the additional liquor throughput brought on from titanate recycle to the heavy black liquor.

Titanate bears no advantage to the mill water balance except when compared to a conventional lime kiln wet scrubber system. In this case there is a 40 to $50 \%$ reduction in water lost to the sewer or atmosphere with the titanate option.

The primary drivers for the economic analyses are the avoided kiln fuel oil cost and the chemical costs for the borate and titanate options. Both the internal rate of return (IRR) and net present value (NPV) analyses were performed on each case and also performed relative to the HTBLG base case. Considering the stand-alone NPVs over the total project life of 25 years, the titanate option clearly has the best NPV of $\$ 10.6 \mathrm{MM}$ primarily from the substantial fuel savings over the base case. The borate option has a high stand-alone IRR of $135 \%$ due to the minimal capital investment required. The borate option still achieves $20 \%$ of the fuel savings of the titanate option. Relative to the base case the titanate option is more economically attractive with an NPV of \$25.2MM and an IRR of $23.9 \%$.

\footnotetext{
${ }^{1}$ Larson, Eric D.; Consonni, Stefano; and Katofsky, Ryan E.; A Cost-Benefit Assessment of Biomass Gasification Power Generation in the Pulp and Paper Industry - Final Report, Princeton University, Princeton, New Jersey, 8 October 2004.
} 
TOTAL NET CASH FLOW

\begin{tabular}{lcccc} 
& \multicolumn{2}{c}{ Stand-Alone } & \multicolumn{2}{c}{ Relative to Base } \\
& $\begin{array}{l}\text { IRR } \\
(\%)\end{array}$ & $\begin{array}{c}\text { NPV } \\
\text { (\$ million) }\end{array}$ & $\begin{array}{l}\text { IRR } \\
(\%)\end{array}$ & $\begin{array}{c}\text { NPV } \\
\text { (\$ million) }\end{array}$ \\
Base - HTBLG & N/A & -14.6 & N/A & 0 \\
Borate & $135 \%$ & 1.4 & N/A & 16.1 \\
Titanate & $15.9 \%$ & 10.6 & $23.9 \%$ & 25.2
\end{tabular}

Borate is a proven partial auto-causticizing agent through various trials around the world. Titanate has been proven successful in the lab. Pilot plant trials are needed to refine the process scope of titanate recovery and confirm overall performance of the proposed system.

\subsection{INTRODUCTION}

The Institute of Paper Science and Technology (IPST) at Georgia Tech has investigated the performance of several compounds that causticize sodium carbonate in situ during the gasification of black liquor. Two of these compounds have proven successful for high temperature black liquor gasification (HTBLG). These include sodium titanate and sodium borate.

Titanate is insoluble and remains in suspension when mixed into the black liquor. By adding sufficient amounts, titanate directly causticizes sodium carbonate during gasification at levels equal to conventional causticizing. The smelt must then be dissolved and the titanate suspended solids are separated and leached to produce white liquor and to recover titanate for recycle. Non-process elements (NPEs) must be acid leached and purged to prevent build-up in the system. The solids loading for titanate direct causticizing is significant being on the order of three times that of calcium oxide causticizing.

Borate has only been tested at the $20 \%$ causticizing level; hence, it is causticizing booster rather than a full replacement of the lime causticizing system. Borate remains soluble throughout the liquor system reacting with carbonate during gasification and then forming sodium hydroxide and converting back to its original form during smelt dissolving. Therefore it is considered an autocausticizing agent. Also, because borate is soluble and remains in the liquor cycle, only small amounts 
of makeup are required to maintain adequate liquor concentration. The makeup system is a minor capital expense.

The purpose of this mill integration study is to develop the most likely process configuration for the borate and titanate options based on the reference mill design basis, perform capital cost estimates for the options, and then to perform economic evaluations for the options as compared to the base case. The base case is HTBLG with a conventional causticizing operation that has been upgraded with oxygen enriched fuel oil firing in the lime kiln.

The reference mill basis used for this study is the same as that used in the study entitled "A Cost-Benefit Assessment of Biomass Gasification Power Generation in the Pulp and Paper Industry - Final Report" by E. Larson, S. Consumi, and R. Katofsky, October 8, 2003 (from this point forward referred to as the Larson Study) . This was done so that the economics of this study could be used to compare to the results of the Larson Study.

\subsection{DESIGN BASIS AND MILL CHARACTERIZATION}

The reference mill used for this study is an integrated pulp and paper mill producing uncoated freesheet paper from a 65/35 mix of hardwood and softwood. The mill produces about 5.4 MM Ibs/day of black liquor solids (BLS). The HTBLG case data from the Larson Study is used for the base case in this study. Table 1 shows the basic data used for the study. 
Table 1

\section{Reference Mill Basis Data} (Larson Study)

Product Flow

Unbleached Pulp Rate

Mill Hardwood/Softwood Mix

Digester Yield

Wood To Process ( $91 \%$ of total)

Hog Fuel ( $9 \%$ of total)

Total Wood Used

Black Liquor Solids Concentration

BL Solids Flow Rate

BL Specific Gravity

BL Flow

BL Energy Content

BL Solids Composition, mass \%

\begin{tabular}{|c|c|}
\hline md mtpd & 1725 \\
\hline bd stpd & 1580 \\
\hline$\% \mathrm{HW}, \% \mathrm{SW}$ & $65 \% \mathrm{HW}, 35 \% \mathrm{SW}$ \\
\hline$\%$ for softwood & 48.75 \\
\hline$\%$ for hardwood & 49.75 \\
\hline bd stpd & 3,208 \\
\hline bd stpd & 317 \\
\hline bd stpd & 3,525 \\
\hline$\%$ solids & 80 \\
\hline Ib BLS per day & $5,419,646$ \\
\hline kg BLS per day & $2,458,311$ \\
\hline BLS mtpd & 2,458 \\
\hline & 1.428 \\
\hline Ipm & 1,495 \\
\hline kJ per kg of BLS (HHV) & 13,874 \\
\hline Btu per lb of BLS (HHV) & 5,966 \\
\hline MW, HHV & 394.7 \\
\hline C & 32.97 \\
\hline $\mathbf{H}$ & 3.70 \\
\hline 0 & 36.88 \\
\hline $\mathbf{s}$ & 4.27 \\
\hline $\mathrm{Na}$ & 20.03 \\
\hline K & 1.93 \\
\hline Ash/Cl & 0.22 \\
\hline
\end{tabular}

1725

580

8.75

317

3,525

80 
Table 2 shows the reference mill HTBLG chemical recovery data.

Table 2
HTBLG Chemical Recovery Data (Larson Study)

$\begin{array}{rr}\text { Wood charge, mt/d } & 3,198 \\ \text { Causticization efficiency, \% } & 81 \% \\ \text { Active Alkali (as } \mathrm{Na}_{2} \mathrm{O} \text { ), mtpd } & 584 \\ \text { Active Alkali (as } \mathrm{Na}_{2} \mathrm{O} \text { )/Wood } & 0.183 \\ \text { Lime availability, \% } & 90 \% \\ \text { White Liquor in lime mud, mtpd } & 749 \\ \text { Water for slaking, mtpd } & 137.5 \\ \text { Green Liquor TTA, g/l as } \mathrm{Na}_{2} \mathrm{O} & 130 \\ \text { Water in White Liquor, mtpd } & 5,240 \\ \text { White Liquor TTA, g/l as } \mathrm{Na}_{2} \mathrm{O} & 133 \\ \text { TTA in Weak Wash, mtpd } & 87.9\end{array}$

$\begin{array}{rrr}\text { Black Liquor } & \mathrm{mtpd} & \mathrm{mtph} \\ \mathrm{BLS} & 2,458 & 102 \\ \mathrm{~S} & 105 & 4.38 \\ \mathrm{Na} & 492.4 & 20.52 \\ \mathrm{~K} & 47.5 & 1.98 \\ \mathrm{Cl} & 2.7 & 0.11 \\ \text { Ash } & 2.7 & 0.11\end{array}$

$\begin{array}{rrr}{ }^{*} \text { Smelt } & \text { mtpd } & \text { mtph } \\ \mathrm{Na}_{2} \mathrm{~S} & 120.0 & 5.0 \\ \mathrm{NaOH} & 20.0 & 0.8 \\ \mathrm{Na}_{2} \mathrm{CO}_{3} & 1005.6 & 41.9 \\ \mathrm{NaCl} & 4.5 & 0.2 \\ \text { Ash } & 2.7 & 0.1 \\ \text { TTA } & 1152.8 & 48.0\end{array}$

\footnotetext{
* Note - the Larson Study assumes that potassium and sodium are equivalent and both elements are included in the smelt sodium compounds.
} 


\subsection{PROCESS DESCRIPTION}

\subsection{Base Case}

The base case process is based on HTBLG followed by conventional calcium oxide causticizing. See Figure 2. Since HTBLG will increase smelt sodium carbonate by about $16 \%$, the lime requirement for slaking increases by a like amount. This puts an increase load on the lime kiln. Considering that many mills are kiln limited and the hypothetical mill is at its kiln design limit, the Larson Study includes oxygen enrichment, a new kiln burner system, and new refractory brick to increase the kiln capacity.

The flow rates for smelt, green liquor, white liquor, and lime are taken directly from the Larson Study for the base case. Dregs flow rate is assumed to be $0.2 \mathrm{mtph}$ based on literature factors and the pulp production.

\subsection{Borate Case (Auto Causticizing)}

Borate autocausticizing is a partial causticization process $(20 \%$ of lime is replaced with borate). This means that the conventional lime caustic plant continues to run but at a reduced rate. Borate in the form of sodium tetraborate pentahydrate $\left(\mathrm{Na}_{2} \mathrm{~B}_{4} \mathrm{O}_{7}-5 \mathrm{H}_{2} \mathrm{O}\right)$ is added to the liquor system to achieve the desired level of lime substitution. Once this level is achieved, borate can be made up to the liquor system in small amounts to account for natural system losses.

For the borate case, borate is fed to a small mix tank from a supersack/screw feeder. A side stream of clarified green liquor is sent to the mix tank to dissolve and absorb the borate. This green liquor/borate stream then flows to the slaker by gravity. See Figure 3.

A spreadsheet balance was used to develop the chemical flows and borate makeup. See Appendix $C$ for details on borate chemistry. Borate makeup is based on lime substitution, lime availability, white liquor causticity, borate loss rate, and borate reaction efficiency.

\subsection{Titanate Case (Direct Causticizing)}

Titanate direct causticizing is for full $100 \%$ substitution of lime, hence, the conventional caustic plant is shut down. For the economical use of titanate, it must be recovered and recycled back to the black liquor prior to gasification. Following smelt dissolving, titanate remains in the green liquor as a suspended solid. By assuming physical properties of the titanate being similar to lime mud, we can extrapolate to a mill-scale process utilizing three staged leaching tanks for reaction residence time with each stage followed by disc filtration.

The green liquor/titanate slurry goes to a first stage leaching tank. See Figure 4. The leaching tank is agitated to keep the solids in suspension. Each tank is sized for 
60 minutes of residence time to allow adequate mass transfer and leaching of the sodium hydroxide. From the first stage leaching tank, the slurry is pumped to a disc filter. Solids discharge from the filter at $85 \%$ solids. The filtrate from the first stage filtrate tank is essentially white liquor that is transferred to the digester area. The first stage filter discharge solids are diluted and gravity fed to the second stage leaching tank. The second and third leaching stages are configured the same as the first stage. Filtrate moves countercurrent to the solids flow through the system. Hot water or evaporator condensate is added to the third stage filter showers. Titanate solids off the third stage filter are conveyed to a black liquor mix tank prior to the gasifier. A portion of the titanate solids stream (10\%) is transferred to an acid slurry mix tank.

The purpose of the acid slurry tank is to mix hydrochloric acid with the titanate solids. The acid leaches out the NPEs from the titanate. The acid slurry is transferred to a disc filter. Filtrate from the NPE purge filter flows by gravity to the NPE purge filtrate tank. Caustic is added to neutralize the acid. The neutralized filtrate then flows to the sewer. Solids from the NPE purge filter are conveyed to a new black liquor mix tank. Titanium dioxide makeup is added to the black liquor mix tank as well via the screw conveyor. It is assumed that the mill already has available hydrochloric acid and caustic make-down and delivery systems.

Potassium remains in the system either as potassium titanate or potassium hydroxide and carbonate. Potassium lowers the melting point of recovery boiler ash and is a primary cause of boiler tube pluggage in Tomlison recovery boilers. In a HTBLG system, the potassium poses no problem.

A new agitated heavy (50\%) black liquor mix tank is required to recycle the titanate prior to the black liquor concentrator. This allows the $85 \%$ solids titanate recycle stream to be uniformly mixed prior to concentrating the black liquor to $80 \%$ solids for gasification. The titanate suspended solids flow is substantial, adding about $40 \%$ to the overall mass flow of the black liquor. The black liquor volume flow increases about $20 \%$. Although no increase to the evaporation capacity of the black liquor concentrator is required, modifications are required to increase the hydraulic capacity. Primarily pump and motor upgrades are required. An allowance is included in the capital estimate to cover concentrator upgrades for the increased liquor flow. The additional suspended solids should enhance the crystallization process and reduce fouling for $80 \%$ solids liquor production by providing sites for crystallization to take place rather than on heat transfer surface areas.

A WinGEMS ${ }^{\circledR 2}$ balance was used to calculate material flows and temperatures for the titanate recovery and NPE purge process. See Appendix D for titanate chemistry details and Appendix E for the WinGEMS flowsheet. Detailed chemical flows are shown in Figure 4 below. The WinGEMS balance is based on HTBLG smelt chemical flow data from the Larson Study and stoichiometric titanate requirements for causticization. In addition, results from IPST experimental data were also used

\footnotetext{
${ }^{2}$ WinGEMS $^{\circledR}$ is a heat and material balance simulation product from Pacific Simulation, 121 W Sweet Ave, Moscow, ID 83843, www.pacsim.com
} 
for the balance around the caustic leaching stages and the NPE acid leaching stage. Table 3 shows the basis and assumptions for executing the WinGEMS material balance.

Table 3

Titanate WinGEMS Balance Basis and Assumptions

\section{Smelt}

$\mathrm{Na}_{2} \mathrm{CO}_{3}, \mathrm{mt} / \mathrm{hr}$

$\mathrm{NaOH}, \mathrm{mt} / \mathrm{hr}$

$\mathrm{Na}_{2} \mathrm{~S}, \mathrm{mt} / \mathrm{hr}$

$\mathrm{HCl}, \mathrm{mt} / \mathrm{hr}$

NPEs (Dissolved), $\mathrm{mt} / \mathrm{hr}$

Inerts (Suspended), $\mathrm{mt} / \mathrm{hr}$

Black Liquor Sodium Carbonate Converted, \%

1st Leaching Stage Caustic Recovery, \%

2nd Leaching Stage Caustic Recovery, \%

3rd Leaching Stage Caustic Recovery, \%

Titanate Split to NPE Purge, \%

$\mathrm{HCl}$ ratio to Treated Solids, $\mathrm{kg} / \mathrm{kg}$ (w/o potassium)

4.76

0.79

4.73

0

3.15

1.46

88.0

86.1

8.9

3.6

10

0.1

The Titanate split to acid treatment for NPE purge was varied to observe the effect on the steady-state level of NPEs in the recycled titanate. Table 4 and Figure 1 below show the effect on NPE levels at different purge fractions.

Table 4

$\begin{array}{cccc}\begin{array}{c}\text { Fraction to } \\ \text { Acid } \\ \text { Treatment }\end{array} & \begin{array}{c}\text { Fraction of } \\ \text { NPEs in } \\ \text { Recycled } \\ \text { Titanate }\end{array} & \begin{array}{c}\text { HCL } \\ \text { Required, } \\ \text { mt/hr }\end{array} & \begin{array}{c}\text { NaOH } \\ \text { Required, } \\ \text { mt/hr }\end{array} \\ 5 \% & 0.23 & 0.35 & 0.25 \\ 10 \% & 0.15 & 0.67 & 0.47 \\ 15 \% & 0.11 & 0.96 & 0.67 \\ 20 \% & 0.08 & 1.30 & 0.91\end{array}$


Figure 1

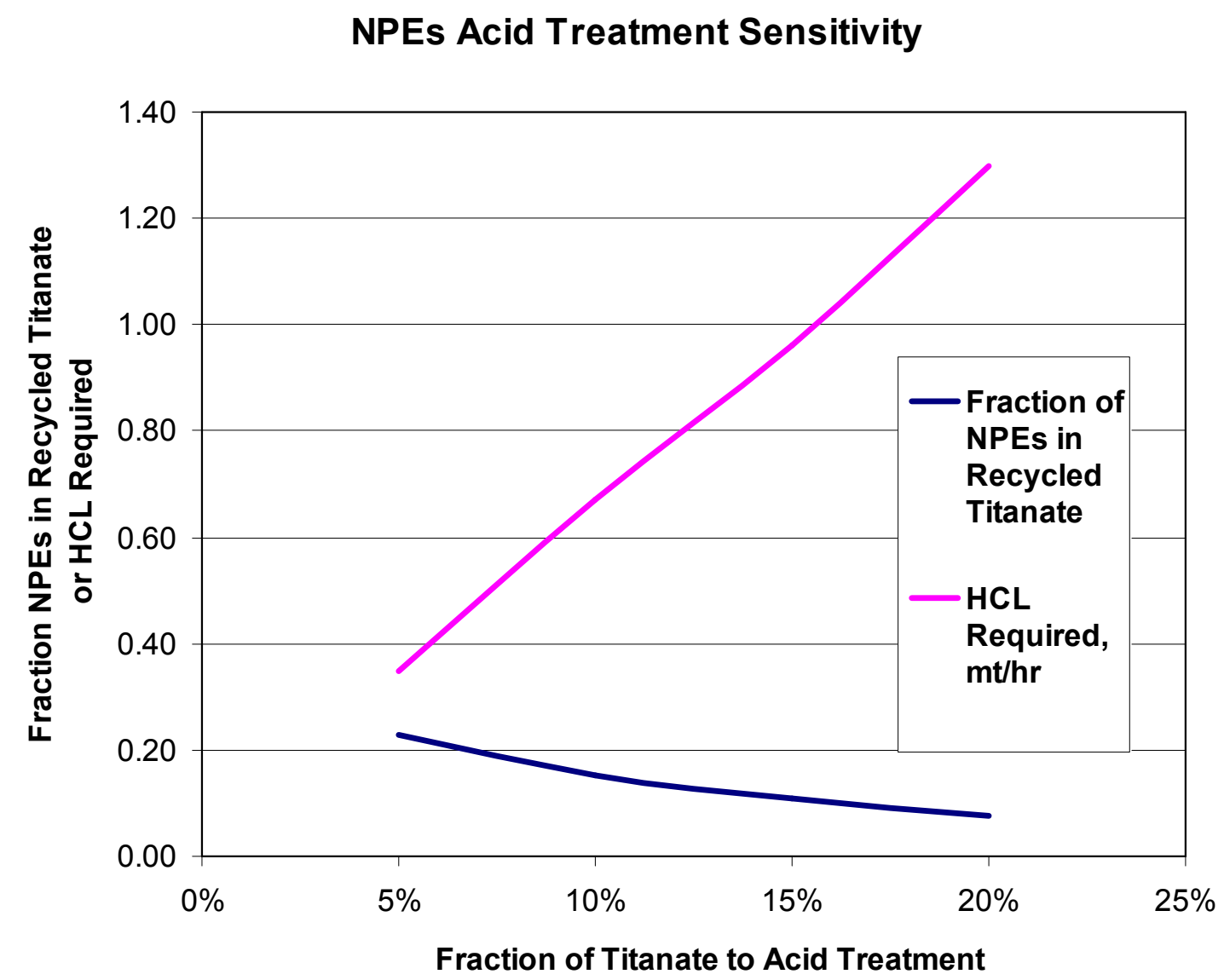

At $5 \%$ fraction to acid treatment, the NPEs level in the recycled titanate is $23 \%$. A higher level of NPEs in the system means a higher dead-load through the process. This causes higher loads on the causticizing equipment and higher hydraulic/pumping loads on the black liquor concentrator system. Of course the acid and caustic costs decrease, but there is still more operational risk with the higher dead-load through the process.

At $10 \%$ fraction to acid treatment, the NPEs level decreases to $15 \%$. Further increases in acid treatment fractions yield lower decreases in the NPEs level. It appears that $10 \%$ fraction to acid treatment is good conservative minimum for the purpose of this mill integration study. In a traditional lime based causticizing system, the amount of NPEs or inerts carried in the reburned lime is typically 10 to $15 \%$ as well. 
Figure 2

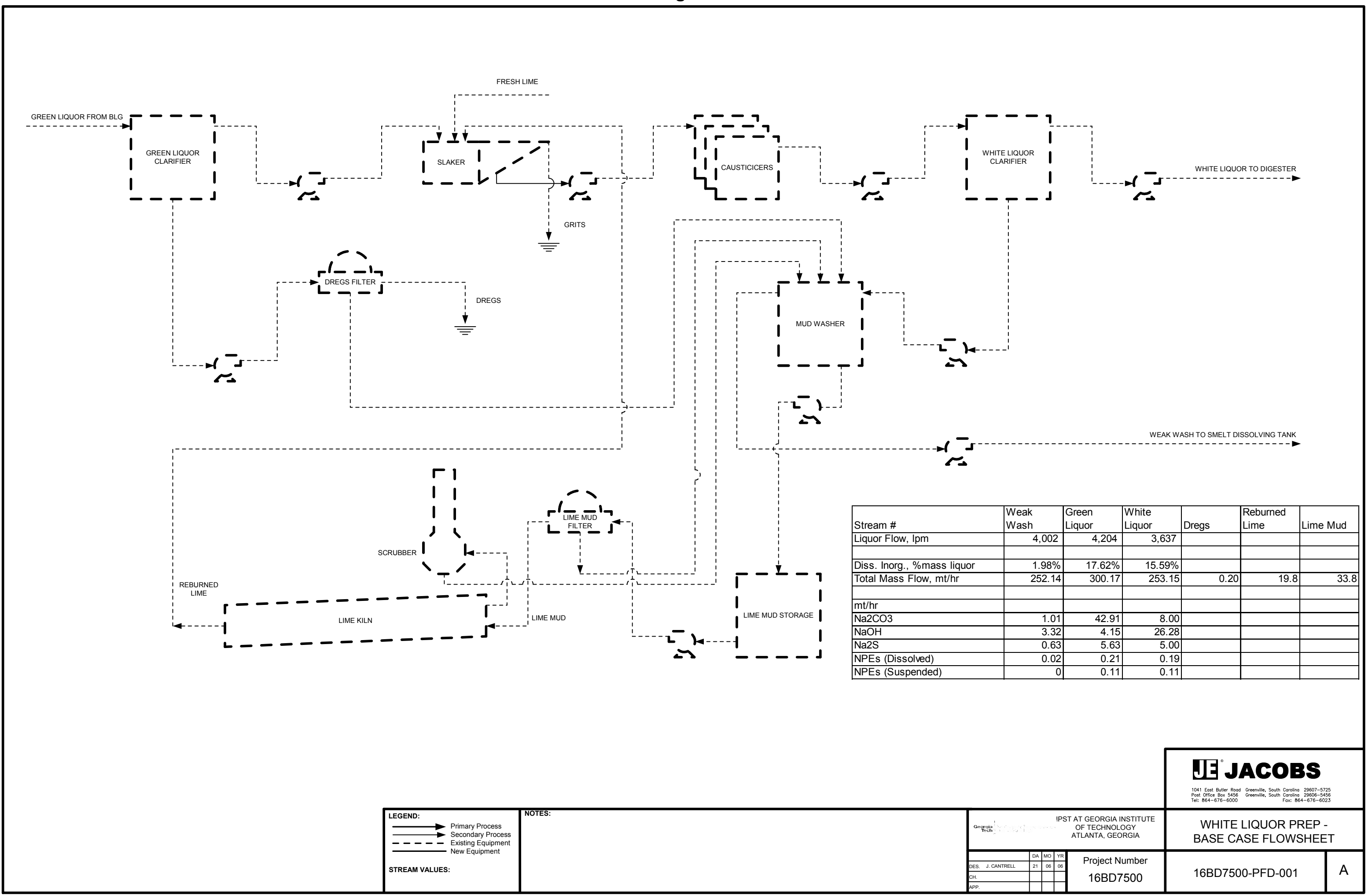


Figure 3

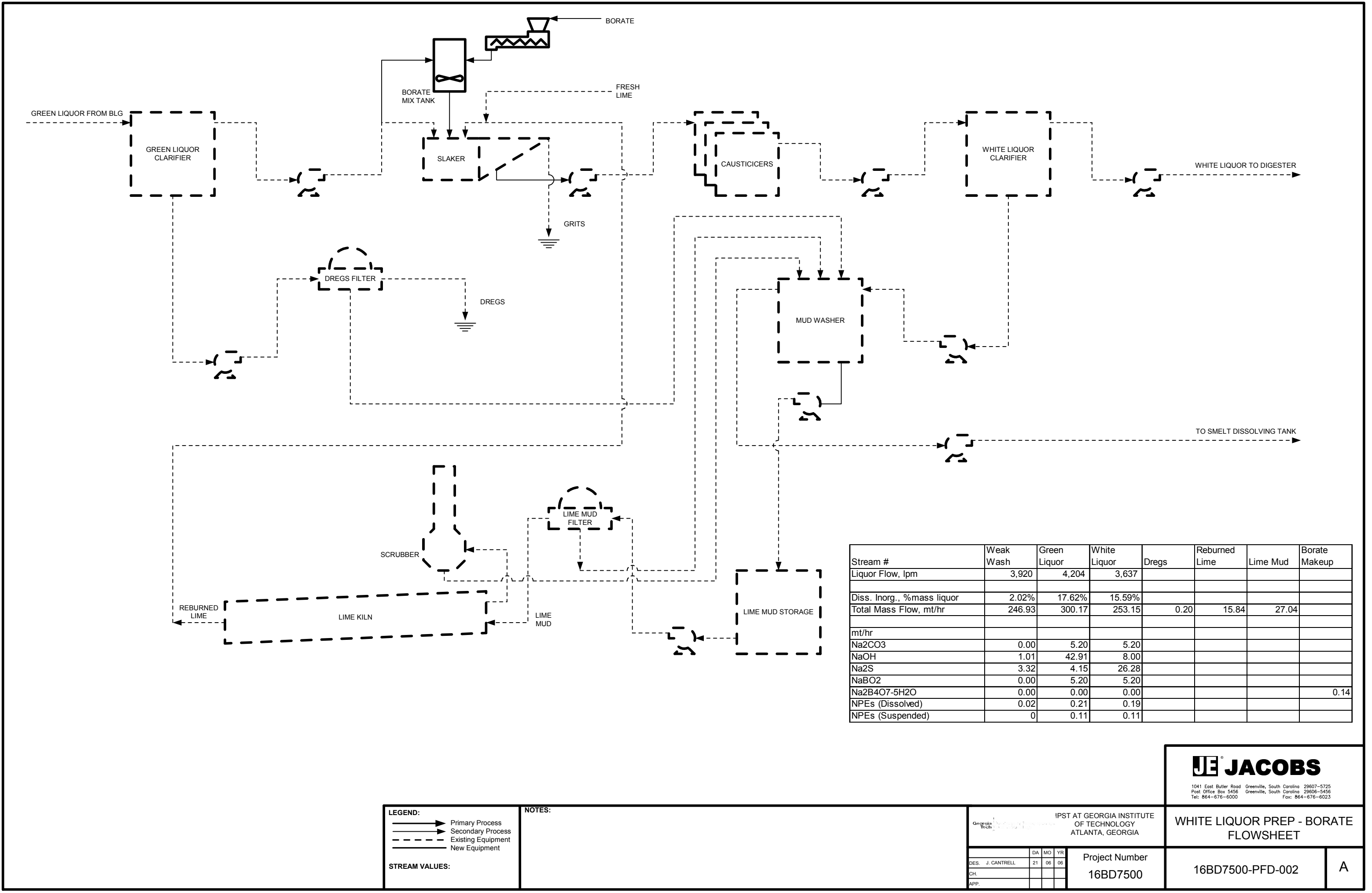


Figure 4

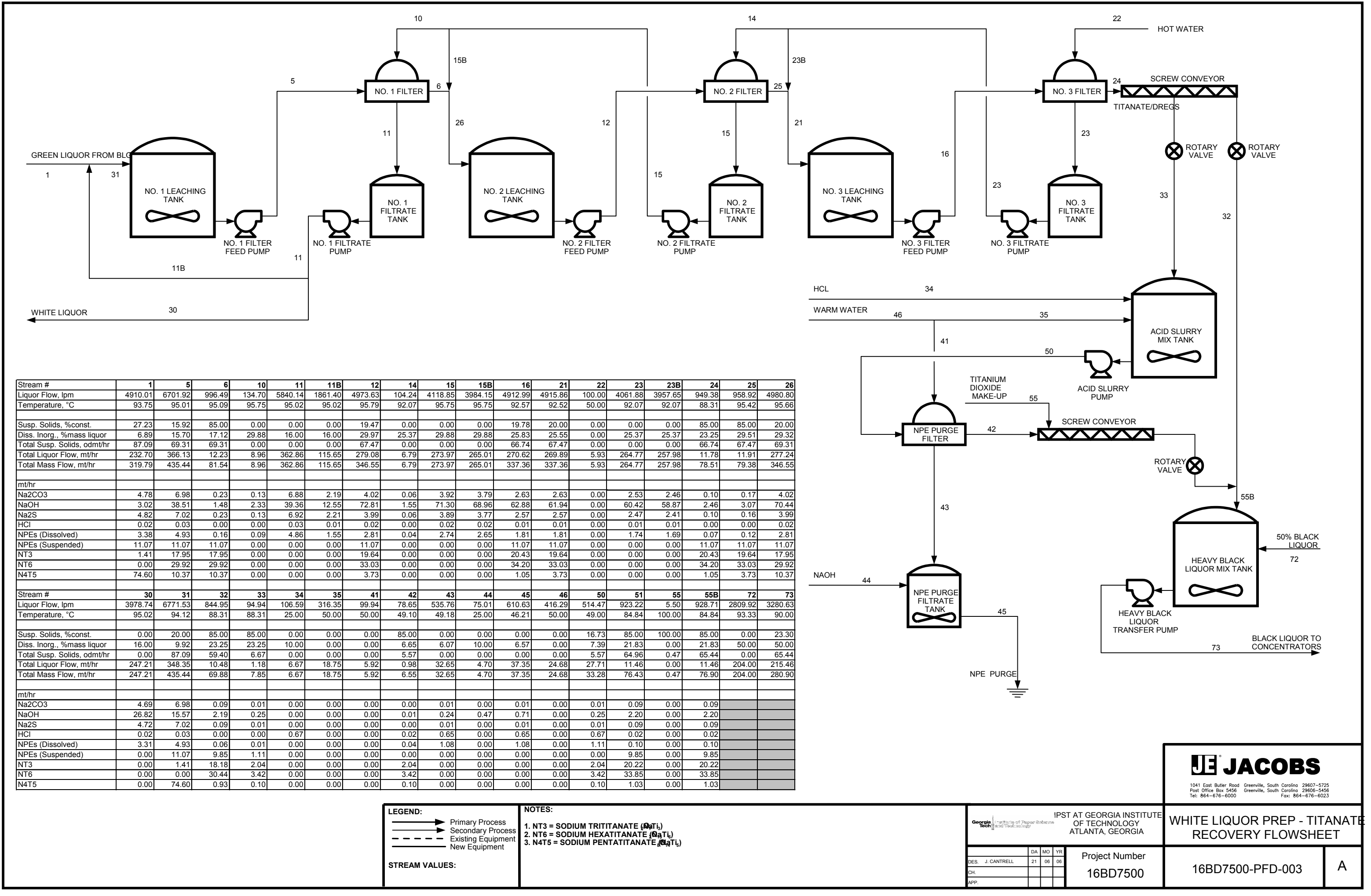




\subsection{Water Balance}

Water usages for the three options are compared in Table 5 along with a base case that uses a scrubber on the kiln flue gas instead of an electrostatic precipitator $(\mathrm{ESP})$.

Water In

Dregs PreCoat Filter

Mud Washer

Mud Filter

Kiln Scrubber

BLG Smelt Dissolving

No. 3 Leach Filter

Dilute Acid

Water to NPE Purge

Dilute Caustic

Total

\section{Water Out}

White Liquor

Smelt Dissolving Tank Stack

Kiln Stack

Slaker Stack

Titanate to Black Liquor

NPE Purge to Sewer

Total

Total Water Lost to

Sewer or Atmosphere

\section{Table 5}

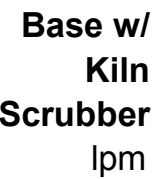

85

2,781

1,502

709

Base
Ipm

Borate

Ipm

Titanate

Ipm

$$
85
$$

3,027

1,201

1,502

4,088

99

100

411

71

5,077

4,368

4,314

4,769

4,018

4,018

4,018

4,018

60

60

60

266

212

24

24

24

169

582

5,077

4,368

4,314

4,769

1,059

350

296

582 
The state of the art mill with an ESP on the lime kiln flue gas uses minimal water because the recycle lime dust is returned dry. The base case assumes a state of the art mill with a lime kiln ESP. The borate case water usage is even less due to a lower lime requirement. The base case with a conventional kiln scrubber has the highest water usage due to evaporative losses. The titanate case water usage is an improvement upon a kiln scrubber but it does require more water than the base case with a kiln ESP. See Figure 5 below.

Figure 5

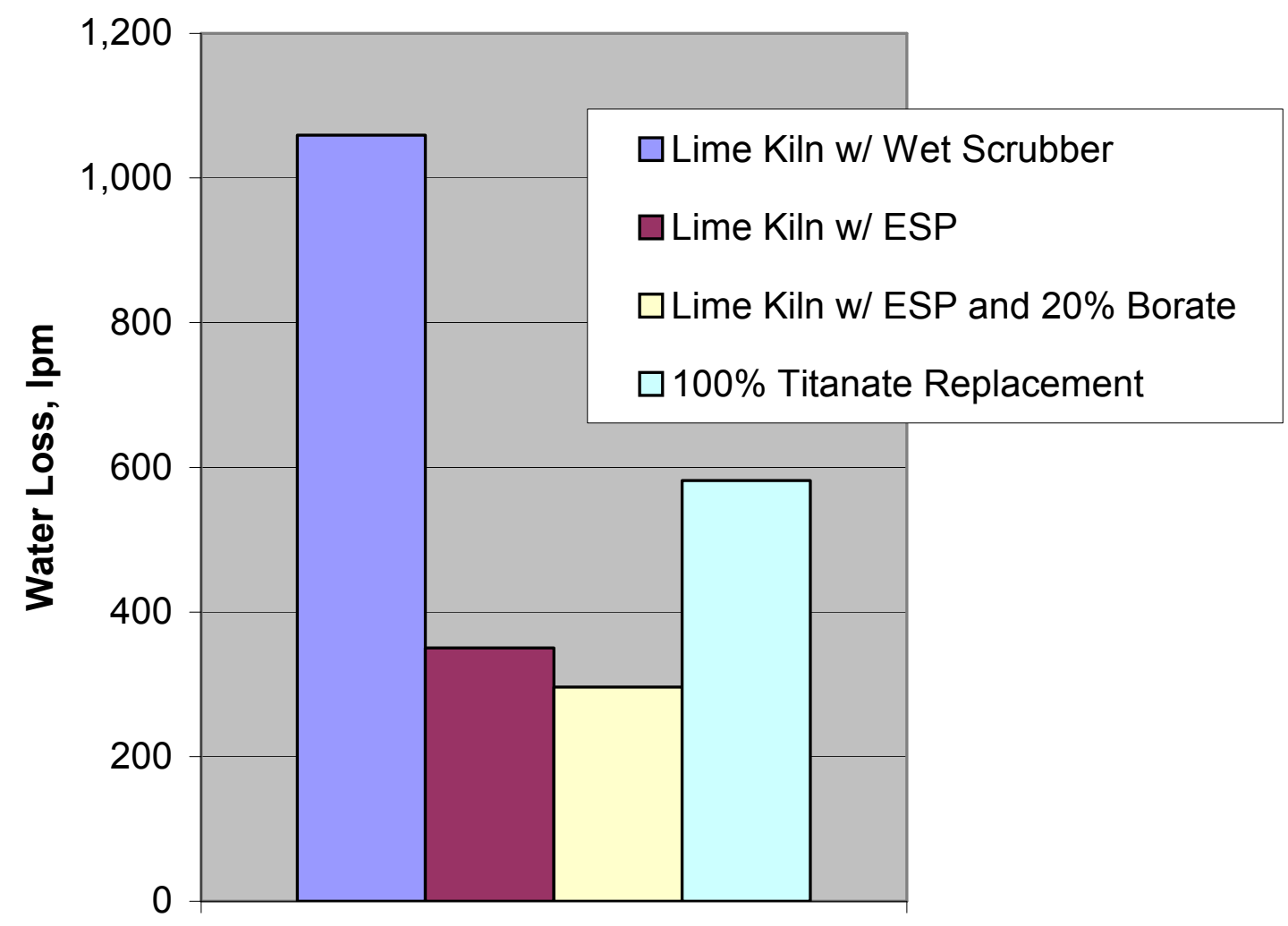




\subsection{BASIS OF ESTIMATED COST}

The estimates are $+/-30 \%$ accuracy factored total installed cost (TIC). The estimates are based on preliminary process flow diagrams, priced equipment lists, and project scope descriptions. Equipment pricing was obtained from Andritz for disc filters and leaching tank agitators. Pump pricing was obtained from ITT Goulds. All other equipment pricing was obtained from Jacobs' historical database. Piping, structural, electrical, and controls material and equipment were factored based on the process equipment direct cost. The estimates assume an engineering, procurement, and construction management (EPC) type contract to execute the project. The estimates assume a site in the southeastern United States, non-union, and no escalation is included. Other estimating assumptions are listed in Table 6 below.

\section{Table 6}

\section{Capital Estimates Assumptions}

\section{General Information}

Basis of Productivity

Basis of Premium Time

Per Diem Requirements

Constructability

Construction Support Labor
Jacobs Standards and Historical Data $100 \%$ of the hours worked on 50 -hour weeks Per Diem at $\$ 5.00$ per hour on $100 \%$ of hours Unknown - depending on site

$20 \%$ of direct labor

Non Payroll Insurance, Taxes, Permits

Sales Tax

Building Permits

Environmental Permits

Construction Management

Engineering

Outside Consultants

Owner's Cost

Spare Parts

Check-Out \& Commissioning

Allowance for Unforeseen

Escalation
$5 \%$ of $\mathrm{TIC}$

Allowance provided for building permits Unknown - depending on site

$4 \%$ of $\mathrm{TIC}$

$15 \%$ of TIC for borate, $10 \%$ of TIC for titanate

DCS configuration, soils testing, and outside survey

$4 \%$ of $\mathrm{TIC}$

$5 \%$ of equipment cost

$5 \%$ of engineering and allowances for vendors $10 \%$ on all costs which equates to $8.33 \%$ of TIC $0 \%$, Estimated in today's costs (October, 2006) 


\subsection{CAPITAL COST ESTIMATES}

The capital cost estimates are summarized in Table 7. The base case capital cost is taken from the Larson Study and factored up to account for inflation from 2002 to 2006.

\section{Table 7}

\section{Capital Cost Summary}

$\begin{array}{lr}\text { Case } & \text { MM\$ } \\ \text { Base } & 1.20 \\ \text { Borate } & 0.17 \\ \text { Titanate } & 31.55\end{array}$

The following sections show the detailed capital cost estimates for borate and titanate cases. 


\subsection{Borate Auto Causticizing}

MORATE SYSTEM - (HYPOTHETICAL MILL)

CLIENT: GEORGIA TECH

LOCATION: ATLANTA, GEORGIA

CONSTRUCTION DURATION:

ESTIMATE TYPE: CLASS 5

G:IESTIMATIIGEORGIA TECHI16BD7500|[EMAIL_BORATE SYSTEM_R0.xIs]PRIME CODE TCS

\begin{tabular}{|c|c|c|c|c|c|c|c|c|c|}
\hline PRIME CODE & DESCRIPTION & W-H & QTTY & UNIT & LABOR & $\begin{array}{l}\text { EQUIPMENT } \\
\end{array}$ & MATERIAL & SUBCONTRACT & $\begin{array}{l}\text { TOTAL COST } \\
\end{array}$ \\
\hline & DIRECT COSTS & & & & & & & & \\
\hline 50 & MAJOR EQUIPMENT & 217 & 0 & 0 & $\$ 10,505$ & $\$ 49,820$ & $\$ 747$ & $\$ 0$ & $\$ 61,072$ \\
\hline 51 & DEMOLITION & 0 & 0 & 0 & $\$ 0$ & $\$ 0$ & $\$ 0$ & $\$ 0$ & $\$ 0$ \\
\hline 52 & SITE EARTHMOVING & 0 & 0 & 0 & $\$ 0$ & $\$ 0$ & $\$ 0$ & $\$ 0$ & $\$ 0$ \\
\hline 53 & SITE IMPROVEMENTS & 0 & 0 & 0 & $\$ 0$ & $\$ 0$ & $\$ 0$ & $\$ 0$ & $\$ 0$ \\
\hline 54 & PILING, CAISSONS & 0 & 0 & 0 & $\$ 0$ & $\$ 0$ & $\$ 0$ & $\$ 0$ & $\$ 0$ \\
\hline 55 & BUILDINGS & 0 & 1 & LOT & $\$ 0$ & $\$ 0$ & $\$ 0$ & $\$ 0$ & $\$ 0$ \\
\hline 56 & CONCRETE & 29 & 2 & $\mathrm{CY}$ & $\$ 1,221$ & $\$ 0$ & $\$ 611$ & $\$ 0$ & $\$ 1,832$ \\
\hline 57 & MASONRY, REFRACTORY & 0 & 0 & 0 & \$0 & $\$ 0$ & $\$ 0$ & $\$ 0$ & $\$ 0$ \\
\hline 58 & STRUCTURAL STEEL & 11 & 0 & TN & $\$ 458$ & $\$ 0$ & $\$ 749$ & $\$ 0$ & \\
\hline 59 & ROOFING AND SIDING & 0 & 0 & 0 & $\$ 0$ & $\$ 0$ & $\$ 0$ & $\$ 0$ & $\$ 0$ \\
\hline 60 & FIRE PROOFING & 0 & 0 & 0 & $\$ 0$ & $\$ 0$ & $\$ 0$ & $\$ 0$ & $\$ 0$ \\
\hline 61 & PROCESS DUCTWORK (NON-BUILDING) & 0 & 0 & 0 & $\$ 0$ & $\$ 0$ & $\$ 0$ & $\$ 0$ & $\$ 0$ \\
\hline 62 & PIPING & 126 & 0 & LF & $\$ 6,107$ & $\$ 0$ & $\$ 5,973$ & $\$ 0$ & $\$ 12,080$ \\
\hline 63 & INSULATION - PIPE, EQUIPMENT \& DUCTWORK & 0 & 0 & 0 & \$o & $\$ 0$ & \$o & $\$ 0$ & $\$ 0$ \\
\hline 64 & $\begin{array}{l}\text { INSTRUMENTATION } \\
\text { INT }\end{array}$ & 41 & 0 & 0 & $\$ 1,832$ & $\$ 6,107$ & $\$ 1,832$ & $\$ 0$ & $\$ 9,772$ \\
\hline 65 & ELECTRICAL & 118 & 520 & LF & $\$ 5,219$ & $\$ 1,272$ & $\$ 3,069$ & $\$ 0$ & $\$ 9,560$ \\
\hline \multirow{5}{*}{$\begin{array}{l}66 \\
67\end{array}$} & PAINTING, PROTECTIVE COATINGS & 0 & 0 & 0 & \$o & $\$ 0$ & $\$ 0$ & $\$ 0$ & $\$ 0$ \\
\hline & FURNITURE, LAB \& SHOP EQUIPMENT & 0 & 0 & 0 & $\$ 0$ & $\$ 0$ & $\$ 0$ & $\$ 0$ & $\$ 0$ \\
\hline & TOTAL DIRECT COSTS & 542 & & & $\$ 25,343$ & $\$ 57,199$ & $\$ 12,981$ & $\$ 0$ & $\$ 95,523$ \\
\hline & $\$ / \mathrm{WH}$ & $\$ 46.75$ & & & & & & & \\
\hline & $\begin{array}{l}\text { CONSTRUCTION INDIRECT COSTS } \\
\end{array}$ & & & & & & & & \\
\hline 75 & CONSTRUCTION SUPPORT LABOR & 108 & & & $\$ 2,488$ & $\$ 0$ & $\$ 0$ & $\$ 0$ & $\$ 2,488$ \\
\hline 76 & TEMPORARY CONSTRUCTION FACILITIES (IN WAGE RATES) & & & & & $\$ 0$ & $\$ 0$ & $\$ 0$ & \\
\hline 78 & PREMIUM TIME & & & & $\$ 1,663$ & $\$ 0$ & $\$ 0$ & $\$ 0$ & $\$ 1,663$ \\
\hline \multirow[t]{2}{*}{79} & CRAFT FRINGE BENEFITS (IN WAGE RATES) & & & & $\$ 0$ & $\$ 0$ & $\$ 0$ & $\$ 0$ & $\$ 0$ \\
\hline & CRAFT PER DIEM ( $\$ 5$ PER HOUR ON $100 \%$ OF THE HOURS) & & & & $\$ 0$ & $\$ 0$ & $\$ 0$ & $\$ 3,253$ & $\$ 3,253$ \\
\hline 80 & PAYROLL TAXES \& INSURANCE (IN WAGE RATES) & & & & $\$ 0$ & $\$ 0$ & $\$ 0$ & $\$ 0$ & $\$ 0$ \\
\hline 83 & SMALL TOOLS (IN WAGE RATES) & & & & $\$ 0$ & $\$ 0$ & $\$ 0$ & $\$ 0$ & $\$ 0$ \\
\hline 84 & CONSUMABLE SUPPLIES (IN WAGE RATES) & & & & $\$ 0$ & $\$ 0$ & $\$ 0$ & $\$ 0$ & $\$ 0$ \\
\hline 85 & CONSTRUCTION EQUIPMENT (IN WAGE RATES) & & & & $\$ 0$ & $\$ 0$ & $\$ 0$ & $\$ 0$ & $\$ 0$ \\
\hline 87 & FIELD STAFF (IN WAGE RATES) & & & & $\$ 0$ & $\$ 0$ & $\$ 0$ & $\$ 0$ & $\$ 0$ \\
\hline 81 & NON-PAYROLL TAX, INSURANCE \& PERMITS & & & & $\$ 0$ & $\$ 0$ & $\$ 649$ & $\$ 2,000$ & $\$ 2,649$ \\
\hline 93 & CONSTRUCTION HOME OFFICE COST (IN WAGE RATES) & & & & $\$ 0$ & $\$ 0$ & $\$ 0$ & $\$ 0$ & $\$ 0$ \\
\hline \multirow{6}{*}{99} & CRAFT START-UP ASSISTANCE & & & & $\$ 773$ & $\$ 0$ & $\$ 0$ & $\$ 0$ & $\$ 773$ \\
\hline & CONTRACTOR'S CONSTRUCTION OVERHEAD \& FEE & & $10.00 \%$ & TCC & $\$ 2,891$ & $\$ 0$ & $\$ 2,045$ & $\$ 525$ & $\$ 5,460$ \\
\hline & TOTAL CONSTRUCTION INDIRECT COSTS & 108 & & & $\$ 7,815$ & $\$ 0$ & $\$ 2,694$ & $\$ 5,778$ & $\$ 16,286$ \\
\hline & TOTAL CONSTRUCTION COSTS (TCC) & 651 & & & $\$ 33,158$ & $\$ 57,199$ & $\$ 15,675$ & $\$ 5,778$ & $\$ 111,809$ \\
\hline & $\begin{array}{ll}/ \mathrm{WH} \\
\end{array}$ & $\$ 58.73$ & & & & & & & \\
\hline & PROJECT INDIRECT COSTS & & & & & & & & \\
\hline 88 & CONSTRUCTION MANAGEMENT & & $4.00 \%$ & TIC & $\$ 0$ & $\$ 0$ & $\$ 0$ & $\$ 6,966$ & $\$ 6,966$ \\
\hline 90 & ENGINEERING PROFESSIONAL SERVICES & & $15.00 \%$ & TIC & $\$ 0$ & $\$ 0$ & $\$ 0$ & $\$ 26,096$ & $\$ 26,096$ \\
\hline 90 & STUDY COST & & $0.00 \%$ & TIC & $\$ 0$ & $\$ 0$ & $\$ 0$ & $\$ 0$ & $\$ 0$ \\
\hline 96 & OUTSIDE CONSULTANT SERVICES & & & & $\$ 0$ & $\$ 0$ & $\$ 0$ & $\$ 2,000$ & $\$ 2,000$ \\
\hline 91 & OWNER'S COST & & $4.00 \%$ & TIC & $\$ 0$ & $\$ 0$ & $\$ 0$ & $\$ 6,966$ & $\$ 6,966$ \\
\hline 70 & SPARE PARTS & & & & $\$ 0$ & $\$ 2,860$ & $\$ 0$ & $\begin{array}{r}\$ 0 \\
91305\end{array}$ & $\$ 2,860$ \\
\hline 71 & NON-CRAFT START-UP ASSISTANCE & & & & $\$ 0$ & $\$ 0$ & $\$ 0$ & $\$ 1,305$ & $\$ 1,305$ \\
\hline 98 & ALLOWANCE FOR UNFORESEEN & & $9.08 \%$ & TIC & $\$ 3,316$ & $\$ 6,006$ & $\$ 1,567$ & $\$ 4,911$ & $\$ 15,800$ \\
\hline \multirow[t]{3}{*}{98} & ESCALATION (EXCLUDED - DATES UNKNOWN) & & $0.00 \%$ & TIC & $\$ 0$ & $\$ 0$ & $\$ 0$ & $\$ 0$ & $\$ 0$ \\
\hline & ROUND OFF & & & & $\$ 526$ & $(\$ 65)$ & $(\$ 242)$ & $(\$ 21)$ & $\$ 198$ \\
\hline & TOTAL PROJECT COSTS & 651 & & & $\$ 37,000$ & $\$ 66,000$ & $\$ 17,000$ & $\$ 54,000$ & $\$ 174,000$ \\
\hline
\end{tabular}


DIRECT COST SUMMARY

$$
\begin{array}{ll}
01100 & \text { MAJOR EQUIPMENT } \\
03000 & \text { CONCRETE } \\
05000 & \text { STRUCTURAL STEEL } \\
15100 & \text { PIPING } \\
17000 & \text { INSTRUMENTATION }
\end{array}
$$

$65 \quad 16000$ ELECTRICAL

$\begin{array}{cc}0 & 0 \\ 1.936785 & \text { CY } \\ 0.263033 & \text { TN } \\ 0 & \text { LF } \\ 0 & 0 \\ 520 & \text { LF }\end{array}$

$\begin{array}{rr}217 & \$ 10,505 \\ 29 & \$ 1,221 \\ 11 & \$ 458 \\ 126 & \$ 6,107 \\ 41 & \$ 1,832 \\ 118 & \$ 5,219\end{array}$

$\$ 49,820$

$\begin{array}{rr}820 & \$ 747 \\ \$ 0 & \$ 611 \\ \$ 0 & \$ 749 \\ \$ 0 & \$ 5,973 \\ 107 & \$ 1,832 \\ 272 & \$ 3,069\end{array}$

$\$ 0 \quad \$ 61,072$

$\$ 1,832$

$\$ 0 \quad \$ 1,207$

$\$ 0 \quad \$ 9,772$

$\begin{array}{lll}520 & \text { LF } & 118\end{array}$

$\$ 1,272$

$\$ 3,069$

$\$ 9,560$ 


\begin{tabular}{|c|c|c|c|c|c|c|c|c|c|c|c|c|c|c|c|}
\hline $\begin{array}{l}\text { LINE } \\
\text { NO. }\end{array}$ & $\begin{array}{l}\text { JE } \\
\text { PRIME } \\
\text { CODE }\end{array}$ & $\begin{array}{c}\text { AREA } 001 \\
\text { BORATE SYSTEM } \\
\text { DESCRIPTION }\end{array}$ & QTY. UNIT & $\begin{array}{l}\text { W.H.II } \\
\text { UNIT }\end{array}$ & $\begin{array}{l}\text { TOTAL } \\
\text { W.H.'s }\end{array}$ & $\begin{array}{l}\text { COST/ } \\
\text { W.H. }\end{array}$ & $\begin{array}{l}\text { TOTAL } \\
\text { DIRECT } \\
\text { LABOR }\end{array}$ & $\begin{array}{l}\text { PROCESS } \\
\text { EQUIPMENT } \\
\text { UNIT COST }\end{array}$ & $\begin{array}{l}\text { TOTAL } \\
\text { PROCESS } \\
\text { EQUIPMENT }\end{array}$ & $\begin{array}{l}\text { MATERIAL } \\
\text { UNIT COST }\end{array}$ & $\begin{array}{c}\text { TOTAL } \\
\text { MATERIAL }\end{array}$ & $\begin{array}{c}\text { SUB } \\
\text { CONTRACT } \\
\text { UNIT COST }\end{array}$ & $\begin{array}{c}\text { TOTAL } \\
\text { SUB } \\
\text { CONTRACTS }\end{array}$ & $\begin{array}{l}\text { UNIT } \\
\text { COST }\end{array}$ & $\begin{array}{l}\text { TOTAL ALL } \\
\text { COSTS }\end{array}$ \\
\hline & & DIRECT COST-DETAILS & & & & & & & & & & & & & \\
\hline 1 & & MAJOR EQUIPMENT & & & & & & & & & & & & & \\
\hline $\begin{array}{l}2 \\
3\end{array}$ & 50 & BORATE FEEDER & $1 \mathrm{EA}$ & 160 & 160 & $\$ 48.34$ & $\$ 7,735$ & $\$ 35,000$ & $\$ 35,000$ & $\$ 0.00$ & $\$ 0$ & $\$ 0.00$ & $\$ 0$ & $\$ 42,735$ & $\$ 42,735$ \\
\hline $\begin{array}{l}4 \\
5\end{array}$ & $\begin{array}{l}50 \\
50\end{array}$ & MOTOR - 1/2 HP @ 1800 RPM & $1 \mathrm{EA}$ & INCL & 0 & $\$ 48.34$ & $\$ 0$ & INCL & $\$ 0$ & $\$ 0.00$ & $\$ 0$ & $\$ 0.00$ & $\$ 0$ & $\$ 0$ & $\$ 0$ \\
\hline $\begin{array}{l}6 \\
7\end{array}$ & $\begin{array}{l}50 \\
50\end{array}$ & BORATE MIX TANK - (70 GALS, 2' DIA. X 3' HT, 316L S.S.) & $1 \mathrm{EA}$ & 24 & 24 & $\$ 48.34$ & $\$ 1,160$ & $\$ 2,000$ & $\$ 2,000$ & $\$ 0.00$ & $\$ 0$ & $\$ 0.00$ & $\$ 0$ & $\$ 3,160$ & $\$ 3,160$ \\
\hline 8 & 50 & BORATE MIX TANK AGITATOR & $1 \mathrm{EA}$ & 24 & 24 & $\$ 48.34$ & $\$ 1,160$ & $\$ 10,000$ & $\$ 10,000$ & $\$ 0.00$ & $\$ 0$ & $\$ 0.00$ & $\$ 0$ & $\$ 11,160$ & $\$ 11,160$ \\
\hline $\begin{array}{r}9 \\
10\end{array}$ & 50 & MOTOR-1/2 HP @ 1800 RPM & $1 \mathrm{EA}$ & 4 & 4 & $\$ 48.34$ & $\$ 193$ & INCL & $\$ 0$ & $\$ 0.00$ & $\$ 0$ & $\$ 0.00$ & $\$ 0$ & $\$ 193$ & $\$ 193$ \\
\hline $\begin{array}{l}11 \\
12\end{array}$ & 50 & FREIGHT & 1 LOT & N/A & 0 & $\$ 48.34$ & $\$ 0$ & $\$ 2,820$ & $\$ 2,820$ & $\$ 0.00$ & $\$ 0$ & $\$ 0.00$ & $\$ 0$ & $\$ 2,820$ & $\$ 2,820$ \\
\hline $\begin{array}{l}13 \\
18\end{array}$ & 50 & SHIMS AND GROUT & 1 LOT & 5 & 5 & $\$ 48.34$ & $\$ 256$ & $\$ 0$ & $\$ 0$ & $\$ 747$ & $\$ 747$ & $\$ 0.00$ & $\$ 0$ & $\$ 1,004$ & $\$ 1,004$ \\
\hline $\begin{array}{l}19 \\
20\end{array}$ & 50 & TOTAL - MAJOR EQUIPMENT & & & 217 & $\$ 48.34$ & $\$ 10,505$ & & $\$ 49,820$ & & $\$ 747$ & & \$0 & & $\$ 61,072$ \\
\hline 21 & & & & & & & & & & & & & & & \\
\hline $\begin{array}{l}170 \\
171\end{array}$ & & CONCRETE & & & & & & & & & & & & & \\
\hline 176 & 56 & FACTORED FROM INSTALLED PROCESS EQUIPMENT COST & 1 LOT & 29.05 & 29 & $\$ 42.04$ & $\$ 1,221$ & $\$ 0$ & $\$ 0$ & $\$ 611$ & $\$ 611$ & $\$ 0$ & $\$ 0$ & $\$ 1,832$ & $\$ 1,832$ \\
\hline $\begin{array}{l}177 \\
178 \\
179 \\
180 \\
192\end{array}$ & 56 & STRUCTURAL STEEL & $2 \mathrm{cY}$ & 15.00 & 29 & $\$ 42.04$ & $\$ 1,221$ & & $\$ 0$ & & $\$ 611$ & & $\$ 0$ & & $\$ 1,832$ \\
\hline 193 & & & & & & & & & & & & & & & \\
\hline $\begin{array}{l}215 \\
216\end{array}$ & 58 & FACTORED FROM INSTALLED PROCESS EQUIPMENT COST & 1 LOT & 10.52 & 11 & $\$ 43.53$ & $\$ 458$ & $\$ 0$ & $\$ 0$ & $\$ 749$ & $\$ 749$ & $\$ 0$ & $\$ 0$ & $\$ 1,207$ & $\$ 1,207$ \\
\hline $\begin{array}{l}217 \\
218\end{array}$ & 58 & TOTAL - STRUCTURAL STEEL & $0.26 \mathrm{TN}$ & 40.00 & 11 & $\$ 43.53$ & $\$ 458$ & & $\$ 0$ & & $\$ 749$ & & $\$ 0$ & & $\$ 1,207$ \\
\hline $\begin{array}{l}219 \\
253 \\
254\end{array}$ & & PIPING & & & & & & & & & & & & & \\
\hline $\begin{array}{l}254 \\
288\end{array}$ & 62 & FACTORED FROM INSTALLED PROCESS EQUIPMENT COST & 1 LOT & 126.33 & 126 & $\$ 48.34$ & $\$ 6,107$ & $\$ 0$ & \$0 & $\$ 5,973$ & $\$ 5,973$ & $\$ 0$ & $\$ 0$ & $\$ 12,080$ & $\$ 12,080$ \\
\hline $\begin{array}{l}299 \\
291\end{array}$ & 62 & TOTAL - PIPING, AVG. Ø__" & LF & & 126 & $\$ 48.34$ & $\$ 6,107$ & & $\$ 0$ & & $\$ 5,973$ & & \$0 & & $\$ 12,080$ \\
\hline $\begin{array}{l}292 \\
304 \\
305\end{array}$ & & INSTRUMENTATION & & & & & & & & & & & & & \\
\hline 317 & 64 & FACTORED FROM INSTALLED PROCESS EQUIPMENT COST & 1 LOT & 41.28 & 41 & $\$ 44.38$ & $\$ 1,832$ & $\$ 6,107$ & $\$ 6,107$ & $\$ 1,832$ & $\$ 1,832$ & $\$ 0$ & $\$ 0$ & $\$ 9,772$ & $\$ 9,772$ \\
\hline $\begin{array}{l}319 \\
320\end{array}$ & 64 & TOTAL - INSTRUMENTATION & & & 41 & $\$ 44.38$ & $\$ 1,832$ & & $\$ 6,107$ & & $\$ 1,832$ & & \$0 & & $\$ 9,772$ \\
\hline $\begin{array}{l}321 \\
322 \\
323\end{array}$ & & ELECTRICAL & & & & & & & & & & & & & \\
\hline $\begin{array}{l}325 \\
325 \\
328\end{array}$ & 65 & MOTOR CONTROL CENTERS & $2 \mathrm{EA}$ & 4.00 & 8 & $\$ 44.38$ & $\$ 355$ & $\$ 600.00$ & $\$ 1,200$ & $\$ 0.00$ & $\$ 0$ & $\$ 0.00$ & $\$ 0$ & $\$ 777.53$ & $\$ 1,555$ \\
\hline $\begin{array}{l}329 \\
331\end{array}$ & 65 & MINOR ELECTRICAL - WIRING DEVICES & 4 EA & 0.50 & 2 & $\$ 44.38$ & $\$ 89$ & $\$ 0.00$ & $\$ 0$ & $\$ 50.00$ & $\$ 200$ & $\$ 0.00$ & $\$ 0$ & $\$ 72.19$ & $\$ 289$ \\
\hline $\begin{array}{l}332 \\
335\end{array}$ & 65 & GROUND RODS / WIRE & $20 \mathrm{LF}$ & 0.10 & 2 & $\$ 44.38$ & $\$ 89$ & $\$ 0.00$ & $\$ 0$ & $\$ 3.50$ & $\$ 70$ & $\$ 0.00$ & $\$ 0$ & $\$ 7.94$ & $\$ 159$ \\
\hline $\begin{array}{l}336 \\
337\end{array}$ & 65 & WIRE AND CABLE & $500 \mathrm{LF}$ & 0.05 & 25 & $\$ 44.38$ & $\$ 1,110$ & $\$ 0.00$ & $\$ 0$ & $\$ 1.50$ & $\$ 750$ & $\$ 0.00$ & $\$ 0$ & $\$ 3.72$ & $\$ 1,860$ \\
\hline $\begin{array}{l}338 \\
341\end{array}$ & 65 & CONDUIT & $500 \mathrm{LF}$ & 0.15 & 75 & $\$ 44.38$ & $\$ 3,329$ & $\$ 0.00$ & $\$ 0$ & $\$ 3.75$ & $\$ 1,875$ & $\$ 0.00$ & $\$ 0$ & $\$ 10.41$ & $\$ 5,204$ \\
\hline $\begin{array}{l}342 \\
343\end{array}$ & 65 & TESTING AND STARTUP & 1 LOT & 5.60 & 6 & $\$ 44.38$ & $\$ 249$ & $\$ 0.00$ & $\$ 0$ & $\$ 0.00$ & $\$ 0$ & $\$ 0.00$ & $\$ 0$ & $\$ 248.54$ & $\$ 249$ \\
\hline $\begin{array}{l}344 \\
349\end{array}$ & 65 & FREIGHT & 1 LOT & $N / A$ & 0 & $\$ 44.38$ & $\$ 0$ & $\$ 72.00$ & $\$ 72$ & $\$ 173.70$ & $\$ 174$ & $\$ 0.00$ & $\$ 0$ & $\$ 245.70$ & $\$ 246$ \\
\hline $\begin{array}{l}349 \\
350 \\
351 \\
352 \\
377 \\
378\end{array}$ & 65 & TOTAL - ELECTRICAL & $520 \mathrm{LF}$ & 0.23 & 118 & $\$ 44.38$ & $\$ 5,219$ & & $\$ 1,272$ & & $\$ 3,069$ & & $\$ 0$ & & $\$ 9,560$ \\
\hline 379 & & TOTAL - DIRECT COST & & & 542 & $\$ 46.75$ & $\$ 25,343$ & & $\$ 57,199$ & & $\$ 12,981$ & & $\$ 0$ & & $\$ 95,523$ \\
\hline
\end{tabular}




\subsection{Titanate Direct Causticizing}

JOB: TITINATE SYSTEM (HYPOTHETICAL MILL)

CLIENT: GEORGIA TECH

OCATION: ATLANTA, GEORGIA

COB NUMBER: 16BD7500

CBNSTMET:

G:IESTIMATIIGEORGIA TECHI16BD7500|[EMAIL_TITANATE SYSTEM_R0.xIs]PRIME CODE TCS

ESTMATE DATE: 10/01/0

REVISION NO.: : 0

WAYNE FAILS

\begin{tabular}{|c|c|c|c|c|c|c|c|c|c|}
\hline PRIME CODE & DESCRIPTION & W-H & $\begin{array}{l}\text { QTY } \\
\end{array}$ & UNIT & LABOR & $\begin{array}{l}\text { EQUIPMENT } \\
\end{array}$ & $\begin{array}{l}\text { MATERIAL } \\
\end{array}$ & $\begin{array}{l}\text { SUBCONTRACT } \\
\end{array}$ & $\begin{array}{l}\text { TOTAL COST } \\
\end{array}$ \\
\hline & DIRECT COSTS & & & & & & & & \\
\hline 50 & MAJOR EQUIPMENT & 5,540 & 0 & 0 & $\$ 267,824$ & $\$ 11,840,337$ & $\$ 177,605$ & $\$ 1,000,000$ & $\$ 13,285,767$ \\
\hline 51 & DEMOLITION & 0 & 0 & 0 & \$0 & \$ 10 & \$0 & $\$ 0$ & $\$ 0$ \\
\hline 52 & SITE EARTHMOVING & 0 & 0 & 0 & $\$ 0$ & $\$ 0$ & $\$ 0$ & $\$ 0$ & $\$ 0$ \\
\hline 53 & SITE IMPROVEMENTS & 0 & 0 & 0 & $\$ 0$ & $\$ 0$ & $\$ 0$ & $\$ 0$ & $\$ 0$ \\
\hline 54 & PILING, CAISSONS & 0 & 0 & 0 & $\$ 0$ & $\$ 0$ & $\$ 0$ & $\$ 0$ & $\$ 0$ \\
\hline 55 & BUILDINGS & 8,241 & 1 & LOT & $\$ 346,500$ & $\$ 0$ & $\$ 283,500$ & $\$ 0$ & $\$ 630,000$ \\
\hline 56 & CONCRETE & 6,320 & 421 & $\mathrm{CY}$ & $\$ 265,715$ & $\$ 0$ & $\$ 132,858$ & $\$ 0$ & $\$ 398,573$ \\
\hline 57 & MASONRY, REFRACTORY & 0 & 0 & 0 & $\$ 0$ & $\$ 0$ & \$0 & $\$ 0$ & \\
\hline 58 & STRUCTURAL STEEL & 2,289 & 57 & TON & $\$ 99,643$ & $\$ 0$ & $\$ 163,016$ & $\$ 0$ & $\$ 262,660$ \\
\hline 59 & ROOFING AND SIDING & 0 & 0 & 0 & $\$ 0$ & $\$ 0$ & $\$ 0$ & $\$ 0$ & \\
\hline 60 & FIRE PROOFING & 0 & 0 & 0 & $\$ 0$ & $\$ 0$ & $\$ 0$ & $\$ 0$ & $\$ 0$ \\
\hline 61 & PROCESS DUCTWORK (NON-BUILDING) & 0 & 0 & 0 & $\$ 0$ & $\$ 0$ & $\$ 0$ & $\$ 0$ & $\$ 0$ \\
\hline 62 & PIPING & 29,642 & 7,852 & LF & $\$ 1,432,965$ & $\$ 0$ & $\$ 1,326,399$ & $\$ 0$ & $\$ 2,759,363$ \\
\hline 63 & INSULATION - PIPE, EQUIPMENT \& DUCTWORK & & 0 & 0 & $\$ 0$ & $\$ 0$ & $\$ 0$ & $\$ 0$ & \\
\hline 64 & INSTRUMENTATION & 8,980 & 0 & 0 & $\$ 398,573$ & $\$ 1,328,577$ & $\$ 398,573$ & $\$ 0$ & $\$ 2,125,723$ \\
\hline 65 & ELECTRICAL & 2,715 & 12,940 & LF & $\$ 120,513$ & $\$ 434,860$ & $\$ 55,984$ & $\$ 0$ & $\frac{\$ 2,16,120}{\$ 611,357}$ \\
\hline 66 & PAINTING, PROTECTIVE COATINGS & 0 & 0 & 0 & $\$ 0$ & $\$ 0$ & $\$ 0$ & $\$ 0$ & \\
\hline \multirow[t]{2}{*}{$\begin{array}{l}66 \\
67\end{array}$} & FURNITURE, LAB \& SHOP EQUIPMENT & 0 & 0 & 0 & $\$ 0$ & $\$ 0$ & $\$ 0$ & $\$ 0$ & $\$ 0$ \\
\hline & TOTAL DIRECT COSTS & 63,728 & & & $\$ 2,931,733$ & $\$ 13,603,774$ & $\$ 2,537,935$ & $\$ 1,000,000$ & $\$ 20,073,442$ \\
\hline
\end{tabular}

CONSTRUCTION INDIRECT COSTS

\section{$\$ 46.00$}

$\$ 2,931,733$
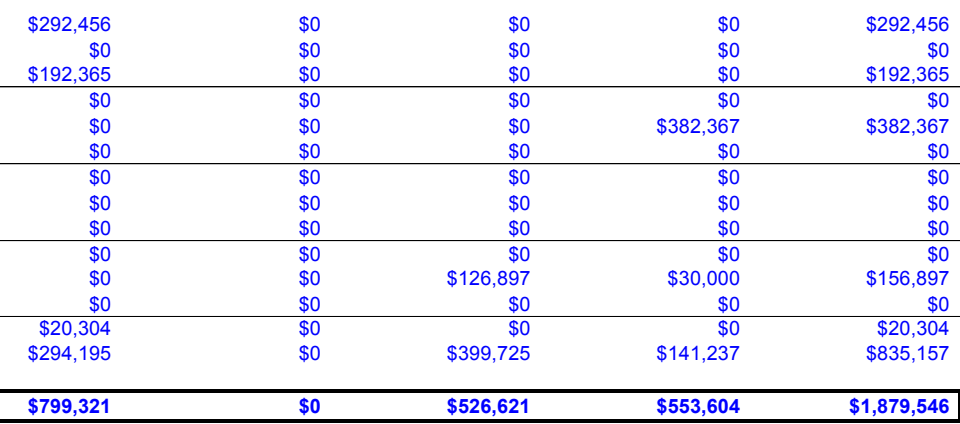

CONSTRUCTION SUPPORT LABOR TEMPORARY CONST
PREMIUM TIME

CRAFT FRINGE BENEFITS (IN WAGE RATES)

12,746

$\begin{array}{rrr} & & \$ 292,456 \\ & \$ 0 \\ & \$ 192,365 \\ & \$ 0 \\ & \$ 0 \\ & \$ 0 \\ & \$ 0 \\ & \$ 0 \\ & \$ 0 \\ & & \$ 0 \\ & \$ 0 \\ & & \$ 0 \\ & & \$ 20,304 \\ 10.00 \% & \text { TCC } & \$ 294,195\end{array}$

$\$ 799,321$

$\$ 13,603,774$

$\$ 3,064,556$

$\$ 1,553,604$

$\$ 21,952,988$

PROJECT INDIRECT COSTS

\begin{tabular}{|c|c|c|c|c|c|}
\hline 88 & CONSTRUCTION MANAGEMENT & $4.00 \%$ & TIC & $\$ 0$ & \\
\hline 90 & ENGINEERING PROFESSIONAL SERVICES & $10.00 \%$ & TIC & $\$ 0$ & \\
\hline 90 & STUDY COST & $0.00 \%$ & TIC & $\$ 0$ & \\
\hline 96 & OUTSIDE CONSULTANT SERVICES & $0.22 \%$ & TIC & $\$ 0$ & \\
\hline 91 & OWNER'S COST & $4.00 \%$ & TIC & $\$ 0$ & \\
\hline 70 & SPARE PARTS & $2.16 \%$ & TIC & $\$ 0$ & $\$ 680$, \\
\hline 71 & NON-CRAFT START-UP ASSISTANCE & $0.98 \%$ & TIC & $\$ 0$ & \\
\hline 98 & ALLOWANCE FOR UNFORESEEN & $9.09 \%$ & TIC & $\$ 373,105$ & $\$ 1,428$, \\
\hline 98 & ESCALATION (EXCLUDED - DATES UNKNOWN) & $0.00 \%$ & TIC & $\$ 0$ & \\
\hline & ROUND OFF & & & $(\$ 160)$ & \\
\hline
\end{tabular}

\begin{tabular}{|c|c|c|c|}
\hline$\$ 0$ & $\$ 0$ & $\$ 1,262,297$ & $\$ 1,262,297$ \\
\hline$\$ 0$ & $\$ 0$ & $\$ 3,156,840$ & $\$ 3,156,840$ \\
\hline$\$ 0$ & $\$ 0$ & $\$ 0$ & $\$ 0$ \\
\hline$\$ 0$ & $\$ 0$ & $\$ 70,000$ & $\$ 70,000$ \\
\hline$\$ 0$ & $\$ 0$ & $\$ 1,262,297$ & $\$ 1,262,297$ \\
\hline ,189 & $\$ 0$ & $\$ 0$ & $\$ 680,189$ \\
\hline$\$ 0$ & $\$ 0$ & $\$ 307,842$ & $\$ 307,842$ \\
\hline ,396 & $\$ 306,456$ & $\$ 761,288$ & $\$ 2,869,245$ \\
\hline$\$ 0$ & $\$ 0$ & $\$ 0$ & $\$ 0$ \\
\hline 591 & (\$12) & (\$167) & $(\$ 697)$ \\
\hline
\end{tabular}


TOTAL

TOTAL

DIRECT COST SUMMARY

$\begin{array}{ll}50 & \text { MAJOR EQUIPMENT } \\ 55.380 & \text { BUILDINGS } \\ 56 & \text { CONCRETE } \\ 58 & \text { STRUCTURAL STEEL } \\ 62 & \text { PIPING } \\ 64 & \text { INSTRUMENTATION } \\ 65 & \text { ELECTRICAL }\end{array}$

$\begin{array}{ccr}0 & 0 & 5,540 \\ 1,800 & \text { SF } & 8,241 \\ 421 & \text { CY } & 6,320 \\ 57 & \text { TON } & 2,289 \\ 7,852 & \text { LF } & 29,642 \\ 0 & 0 & 8,980 \\ 12,940 & \text { LF } & 2,715\end{array}$

INSTRUMENTATION

$\$ 1,432,965$

12,940 LF 2,71

$\begin{array}{rr}\$ 11,840,337 & \$ 177,605 \\ \$ 0 & \$ 283,500 \\ \$ 0 & \$ 132,858 \\ \$ 0 & \$ 163,016 \\ \$ 0 & \$ 1,326,399 \\ \$ 1,328,577 & \$ 398,573 \\ \$ 434,860 & \$ 55,984\end{array}$

$\$ 1,000,000$

$\$ 0$

$\$ 13,285,767$ $\$ 630,000$ $\$ 398,573$

$\$ 2,759,363$

(2, 125,723

$\$ 2,125,723$
$\$ 611,357$

\section{TOTAL - DIRECT COST SUMMARY}




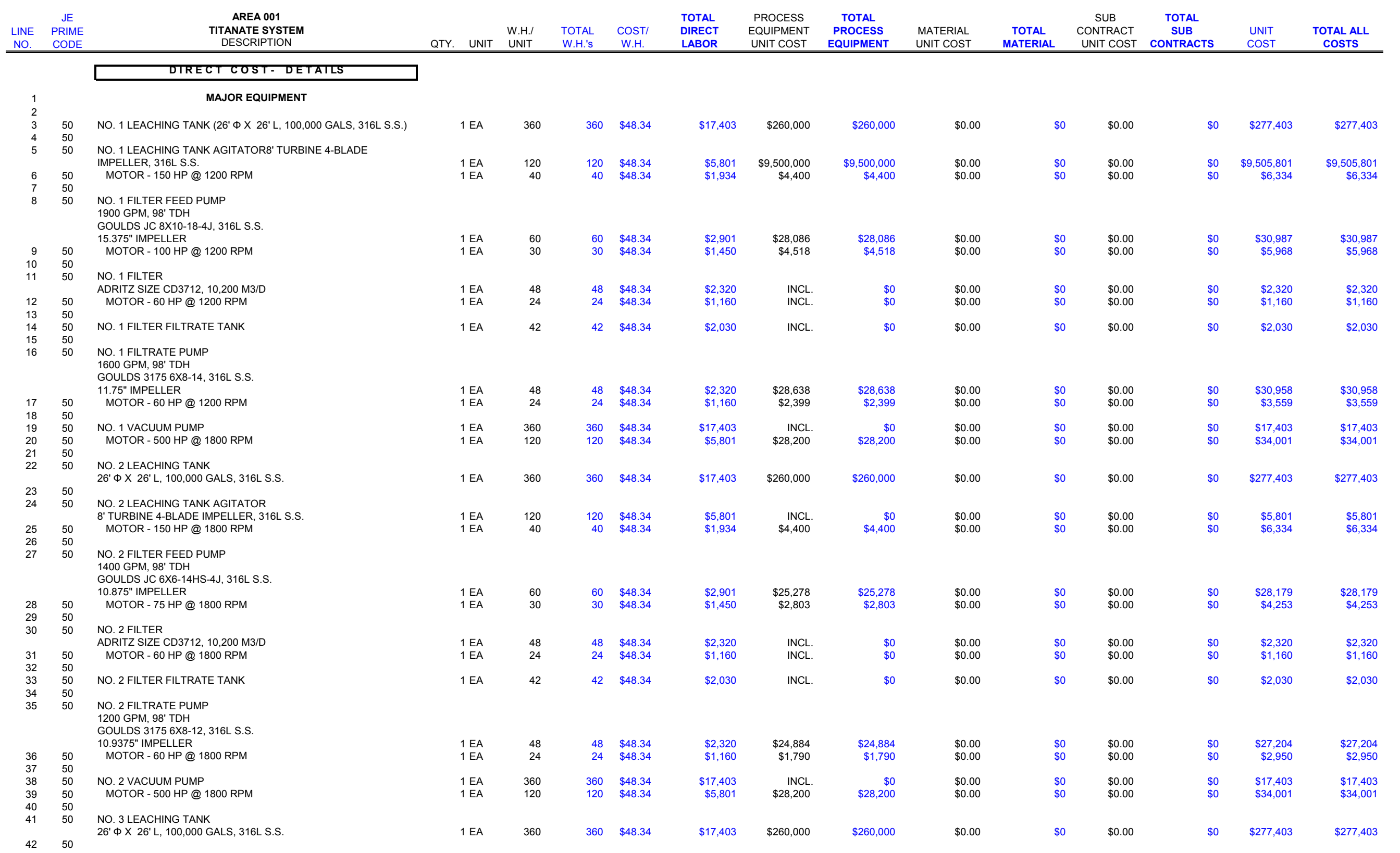




\begin{tabular}{|c|c|c|c|c|c|c|c|c|c|c|c|c|c|c|c|}
\hline $\begin{array}{l}\text { LINE } \\
\text { NO. }\end{array}$ & $\begin{array}{l}\text { JE } \\
\text { PRIME } \\
\text { CODE }\end{array}$ & $\begin{array}{l}\text { AREA } 001 \\
\text { TITANATE SYSTTEM } \\
\text { DESCRIPTION }\end{array}$ & QTY. UNIT & $\begin{array}{l}\text { W.H.II } \\
\text { UNIT }\end{array}$ & $\begin{array}{l}\text { TOTAL } \\
\text { W.H.'s }\end{array}$ & $\begin{array}{l}\text { COST/ } \\
\text { W.H. }\end{array}$ & $\begin{array}{l}\text { TOTAL } \\
\text { DIRECT } \\
\text { LABOR }\end{array}$ & $\begin{array}{l}\text { PROCESS } \\
\text { EQUIPMENT } \\
\text { UNIT COST }\end{array}$ & $\begin{array}{c}\text { TOTAL } \\
\text { PROCESS } \\
\text { EQUIPMENT }\end{array}$ & $\begin{array}{l}\text { MATERIAL } \\
\text { UNIT COST }\end{array}$ & $\begin{array}{c}\text { TOTAL } \\
\text { MATERIAL }\end{array}$ & $\begin{array}{l}\text { SUB } \\
\text { CONTRACT } \\
\text { UNIT COST }\end{array}$ & $\begin{array}{l}\text { TOTAL } \\
\text { SUB } \\
\text { CONTRACTS }\end{array}$ & $\begin{array}{l}\text { UNIT } \\
\text { COST }\end{array}$ & $\begin{array}{l}\text { TOTAL ALL } \\
\text { COSTS }\end{array}$ \\
\hline 43 & 50 & 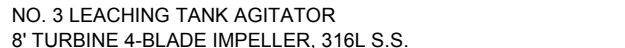 & & & & & & & & & & & & & \\
\hline 44 & 50 & MOTOR-150 HP@ 1800 RPM & $1 \mathrm{EA}$ & 40 & 40 & $\$ 48.34$ & $\$ 1,934$ & $\$ 4,400$ & $\$ 4,400$ & $\$ 0.00$ & $\$ 0$ & $\$ 0.00$ & $\$ 0$ & $\$ 6,334$ & $\$ 6,334$ \\
\hline 46 & 50 & 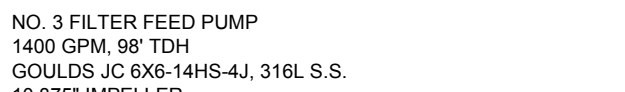 & & & & & & & & & & & & & \\
\hline 47 & 50 & $\begin{array}{l}\text { 10.875" IMPELLER } \\
\text { MOTOR - } 75 \text { HP @ } 1800 \text { RPM }\end{array}$ & $\begin{array}{l}1 \mathrm{EA} \\
1 \mathrm{EA}\end{array}$ & $\begin{array}{l}60 \\
30\end{array}$ & $\begin{array}{l}60 \\
30\end{array}$ & $\begin{array}{l}\$ 48.34 \\
\$ 48.34\end{array}$ & $\begin{array}{l}\$ 2,901 \\
\$ 1,450\end{array}$ & 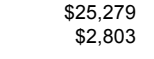 & $\begin{array}{l}\begin{array}{l}\$ 25,279 \\
\$ 2,803\end{array} \\
\text {. }\end{array}$ & $\begin{array}{l}\$ 0.00 \\
\$ 0.00\end{array}$ & $\begin{array}{l}\$ 0 \\
\$ 0\end{array}$ & $\begin{array}{l}\$ 0.00 \\
\$ 0.00\end{array}$ & $\begin{array}{l}\$ 0 \\
\$ 0\end{array}$ & $\begin{array}{l}\$ 28,180 \\
\$ 4,253\end{array}$ & $\begin{array}{l}\$ 28,180 \\
\$ 4,253\end{array}$ \\
\hline 49 & 50 & $\begin{array}{l}\text { NO. } 3 \text { FLITER } \\
\text { ADRITZ SIZE CD } 3712,10,200 \mathrm{M} 3 / \mathrm{D}\end{array}$ & $1 \mathrm{EA}$ & 48 & 48 & & & & \$0 & $\$ 0.00$ & \$0 & & \$0 & $\$ 2,320$ & $\$ 2,320$ \\
\hline $\begin{array}{l}50 \\
51\end{array}$ & $\begin{array}{c}50 \\
50\end{array}$ & MOTOR - 60 HP @ 1800 RPM & $1 \mathrm{EA}$ & 24 & 24 & $\$ 48.34$ & $\$ 1,160$ & INCL. & \$o & $\$ 0.00$ & \$o & $\$ 0.00$ & \$o & $\$ 1,160$ & $\$ 1,160$ \\
\hline 52 & 50 & NO. 3 FILTER FILTRATE TANK & $1 \mathrm{EA}$ & 42 & 42 & $\$ 48.34$ & $\$ 2,030$ & INCL. & $\$ 0$ & $\$ 0.00$ & so & $\$ 0.00$ & $\$ 0$ & $\$ 2,030$ & $\$ 2,030$ \\
\hline 54 & 50 & $\begin{array}{l}\text { NO.3 FILTRATE PUMP } \\
1100 \text { GPM, 98' TDH } \\
\text { GOULS } 31756 \times 8-12,316 \mathrm{~L} . \mathrm{S} . \\
\text { 10.875" IMPELER } \\
\text { MOTOR - 50HP @ } 1800 \text { RPM }\end{array}$ & $\begin{array}{l}1 \mathrm{EA} \\
1 \mathrm{EA}\end{array}$ & $\begin{array}{l}48 \\
24\end{array}$ & ${ }_{24}^{48}$ & $\begin{array}{l}\$ 48.34 \\
\$ 48.34\end{array}$ & $\begin{array}{l}\$ 2,320 \\
\$ 1,160\end{array}$ & $\begin{array}{l}\$ 24,884 \\
\text { INCL. }\end{array}$ & $\$ 24,884$ & $\begin{array}{l}\$ 0.00 \\
\$ 0.00\end{array}$ & $\$ 0$ & $\begin{array}{l}\$ 0.00 \\
\$ 0.00\end{array}$ & $\begin{array}{l}\$ 0 \\
\$ 0\end{array}$ & $\begin{array}{r}\$ 27,204 \\
\$ 1,160\end{array}$ & $\begin{aligned} \$ 27,204 \\
\$ 1,160\end{aligned}$ \\
\hline $\begin{array}{l}57 \\
58\end{array}$ & 50 & $\begin{array}{l}\text { NO. } 3 \text { VACUUM PUMP } \\
\text { MOTOR-500 HP @ } 1800 \text { RPM }\end{array}$ & $\begin{array}{l}1 \mathrm{EA} \\
1 \mathrm{EA}\end{array}$ & $\begin{array}{l}360 \\
120\end{array}$ & $\begin{array}{l}360 \\
120\end{array}$ & $\begin{array}{l}\$ 48.34 \\
\$ 48.34\end{array}$ & $\begin{array}{r}\$ 17,403 \\
\$ 5,801\end{array}$ & $\begin{array}{l}\text { INCL. } \\
\$ 28,200\end{array}$ & $\begin{array}{r}\$ 0 \\
\$ 28,200\end{array}$ & $\begin{array}{l}\$ 0.00 \\
\$ 0.00\end{array}$ & $\$ \$$ & $\begin{array}{l}\$ 0.00 \\
\$ 0.00\end{array}$ & $\begin{array}{l}\$ 0 \\
\$ 0\end{array}$ & $\begin{array}{l}\$ 17,403 \\
\$ 34,001\end{array}$ & $\begin{array}{l}\$ 17,403 \\
\$ 34,001\end{array}$ \\
\hline 60 & $\begin{array}{l}50 \\
50\end{array}$ & $\begin{array}{l}\text { NO. } 3 \text { FLLTER SCREW CONVEYOR } \\
20^{\circ} \text { X } 30^{\circ} \text { L., 316LLS.S. }\end{array}$ & $\begin{array}{l}1 \mathrm{EA} \\
1 \mathrm{EA}\end{array}$ & $\begin{array}{r}240 \\
40\end{array}$ & $\begin{array}{r}240 \\
40\end{array}$ & $\begin{array}{l}\$ 48.34 \\
\$ 48.34\end{array}$ & $\begin{array}{r}\$ 11,602 \\
\$ 1,934\end{array}$ & $\begin{array}{r}\$ 787,637 \\
\$ 4,400\end{array}$ & $\begin{array}{r}\$ 787,637 \\
\$ 4,400\end{array}$ & $\begin{array}{l}\$ 0.00 \\
\$ 0.00\end{array}$ & $\begin{array}{l}\$ 0 \\
\$ 0\end{array}$ & $\begin{array}{l}\$ 0.00 \\
\$ 0.00\end{array}$ & $\begin{array}{l}\$ 0 \\
\$ 0\end{array}$ & $\$ 799,240$ & $\begin{array}{l}\$ 799,240 \\
\$ 6,334\end{array}$ \\
\hline $\begin{array}{l}62 \\
62 \\
63\end{array}$ & $\begin{array}{l}50 \\
50\end{array}$ & ROTARY VALVE, ACID MIX TANK FEED (150 CUFT/HR, 10", $316 \mathrm{~L}$ & & & & & & & & & & & & & \\
\hline 64 & 50 & $\begin{array}{l}\text { S.S.) } \\
\text { MOTOR-3 HP @ } 1800 \text { RPM }\end{array}$ & $\begin{array}{l}1 \mathrm{EA} \\
1 \mathrm{EA}\end{array}$ & $\begin{array}{r}64 \\
6\end{array}$ & $\begin{array}{r}64 \\
6\end{array}$ & $\begin{array}{l}\$ 48.34 \\
\$ 48.34\end{array}$ & 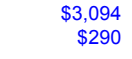 & $\begin{array}{l}\$ 17,250 \\
\text { INCL. }\end{array}$ & $\begin{aligned} \$ 17,250 \\
\$ 0\end{aligned}$ & $\$ \$ 0.00$ & $\begin{array}{l}\$ 0 \\
\$ 0\end{array}$ & $\begin{array}{l}\$ 0.00 \\
\$ 0.00\end{array}$ & $\begin{array}{l}\$ 0 \\
\$ 0\end{array}$ & $\$ 20,344$ & $\begin{array}{r}\$ 20,344 \\
\$ 290\end{array}$ \\
\hline 66 & 50 & $\begin{array}{l}\text { ACID SLURRY MIX TANK ) } 6^{\prime} \Phi \text { X } 9^{\prime} \text { 'L, 1,900 GALS, HASTELLOY } \\
\text { C) }\end{array}$ & $1 \mathrm{EA}$ & 64 & 64 & $\$ 48.34$ & $\$ 3,094$ & INCL. & so & $\$ 0.00$ & so & $\$ 0.00$ & \$o & $\$ 3,094$ & $\$ 3,094$ \\
\hline $\begin{array}{l}67 \\
68\end{array}$ & $\begin{array}{c}50 \\
50\end{array}$ & ACID SLURRY MIX TANK AGITATOR - 72" TURBINE 4-BLADE & & & & & & & & & & & & & \\
\hline 69 & 50 & $\begin{array}{l}\text { IMPELLER, HASTELLOY C } \\
\text { MOTOR-20 HP @ 1800 RPM }\end{array}$ & $\begin{array}{l}1 \mathrm{EA} \\
1 \mathrm{EA}\end{array}$ & $\begin{array}{l}40 \\
15\end{array}$ & $\begin{array}{l}40 \\
15\end{array}$ & $\begin{array}{l}\$ 48.34 \\
\$ 48.34\end{array}$ & $\begin{aligned} \$ 1,934 \\
\$ 725\end{aligned}$ & $\begin{array}{l}\$ 30,000 \\
\text { INCL. }\end{array}$ & $\begin{array}{r}\$ 30,000 \\
\$ 0\end{array}$ & $\begin{array}{l}\$ 0.00 \\
\$ 0.00\end{array}$ & $\begin{array}{l}\$ 0 \\
\$ 0\end{array}$ & $\$ \$ \$ 0.00$ & $\begin{array}{l}\$ 0 \\
\$ 0\end{array}$ & $\begin{array}{l}\$ 31,934 \\
\$ 725.14\end{array}$ & $\begin{array}{r}\$ 31,934 \\
\$ 725\end{array}$ \\
\hline 71 & 50 & $\begin{array}{l}\text { ACID SLURRY PUMP } \\
\text { 160 GPM, 98 TDH } \\
\text { GOULDS 3175 336-12, CD4MCUN } \\
9.8125 " \text { IIPELER } \\
\text { MOTOR -20 HP @ 1800 RPM }\end{array}$ & $\begin{array}{l}\text { TEA } \\
1 \mathrm{EA}\end{array}$ & 15 & $\begin{array}{l}40 \\
15\end{array}$ & $\begin{array}{l}\$ 88.34 \\
\$ 48.34\end{array}$ & $\begin{array}{r}\$ 1,934 \\
\$ 725\end{array}$ & $\begin{array}{c}\$ 2,063 \\
\$ 803\end{array}$ & \$2,063 $\$ \$ 803$ & $\begin{array}{l}\$ \$ 0.00 \\
\$ 0.00\end{array}$ & $\begin{array}{l}\$ 0 \\
\$ 0\end{array}$ & $\begin{array}{l}\$ 0.00 \\
\$ 0.00\end{array}$ & $\begin{array}{l}\$ 0 \\
\$ 0\end{array}$ & $\begin{array}{r}\$ 22,537 \\
\$ 1,528\end{array}$ & $\begin{array}{l}\$ 22,537 \\
\$ 1,528\end{array}$ \\
\hline $\begin{array}{l}74 \\
75\end{array}$ & $\begin{array}{l}50 \\
50\end{array}$ & $\begin{array}{l}\text { NPE PURGE FILTER (ANDRITZ SIZE EIRS 3030) } \\
\text { MOTOR-1/2 HP@ } 1800 \text { RPM }\end{array}$ & $\begin{array}{l}1 \mathrm{EA} \\
1 \mathrm{EA}\end{array}$ & $\begin{array}{r}24 \\
6\end{array}$ & $\begin{array}{r}24 \\
6\end{array}$ & $\begin{array}{l}\$ 48.34 \\
\$ 48.34\end{array}$ & $\begin{array}{r}\$ 1,160 \\
\$ 290\end{array}$ & $\begin{array}{l}\text { INCL. } \\
\text { INCL. }\end{array}$ & $\begin{array}{l}\text { so } \\
\text { so }\end{array}$ & $\begin{array}{l}\$ 0.00 \\
\$ 0.00\end{array}$ & $\begin{array}{l}\text { so } \\
\text { so }\end{array}$ & $\begin{array}{l}\$ 0.00 \\
\$ 0.00\end{array}$ & $\begin{array}{l}\$ 0 \\
\text { \$0 }\end{array}$ & $\begin{array}{r}\$ 1,160 \\
\$ 290.06\end{array}$ & $\begin{array}{r}\$ 1,160 \\
\$ 290\end{array}$ \\
\hline 77 & 50 & NPE PURGE FILTRATE TANK & $1 \mathrm{EA}$ & 64 & 64 & $\$ 48.34$ & $\$ 3,094$ & INCL. & $\$ 0$ & $\$ 0.00$ & so & $\$ 0.00$ & $\$ 0$ & $\$ 3,094$ & $\$ 3,094$ \\
\hline $\begin{array}{l}79 \\
80\end{array}$ & 50 & $\begin{array}{l}\text { NPE PURGE FLLTRATE TANK AGITATOR48" TURBINE 4-BLADE } \\
\text { IMPELLER, HASTELLY C } \\
\text { MOTOR - } 2 \text { HP @ } 1800 \text { RPM }\end{array}$ & $\begin{array}{l}1 \mathrm{EA} \\
1 \mathrm{EA}\end{array}$ & $\begin{array}{r}20 \\
6\end{array}$ & $\begin{array}{r}20 \\
6\end{array}$ & $\begin{array}{l}\$ 48.34 \\
\$ 48.34\end{array}$ & $\$ \$ \$ 967$ & $\begin{array}{l}\$ 20,000 \\
\text { INCL. }\end{array}$ & $\begin{aligned} \$ 20,000 \\
\$ 0\end{aligned}$ & $\begin{array}{l}\$ 0.00 \\
\$ 0.00\end{array}$ & $\$ \$$ & $\begin{array}{l}\$ 0.00 \\
\$ 0.00\end{array}$ & $\begin{array}{l}\$ 0 \\
\$ 0\end{array}$ & $\$ 20,967$ & $\begin{array}{r}\$ 20,967 \\
\$ 290\end{array}$ \\
\hline $\begin{array}{l}82 \\
83\end{array}$ & $\begin{array}{l}50 \\
50\end{array}$ & $\begin{array}{l}\text { TITANATE SCREW CONVEYOR (9" } \Phi \times 30^{\circ} \text { L, HASTELLOY C) } \\
\text { MOTOR - } 5 \text { HP @ } 1800 \text { RPM }\end{array}$ & $\begin{array}{l}1 \mathrm{EA} \\
1 \mathrm{EA}\end{array}$ & $\begin{array}{r}240 \\
5\end{array}$ & $\begin{array}{r}240 \\
5\end{array}$ & $\begin{array}{l}\$ 48.34 \\
\$ 48.34\end{array}$ & $\begin{array}{r}\$ 11,602 \\
\$ 242\end{array}$ & $\begin{array}{l}\$ 160,000 \\
\text { INCL. }\end{array}$ & $\$ 160,000$ & $\begin{array}{l}\$ 0.00 \\
\$ 0.00\end{array}$ & $\begin{array}{l}\$ 0 \\
\$ 0\end{array}$ & $\begin{array}{l}\$ 0.00 \\
\$ 0.00\end{array}$ & $\begin{array}{l}\$ 0 \\
\$ 0\end{array}$ & $\begin{array}{l}\$ 111,602 \\
\$ 241.71\end{array}$ & $\begin{array}{l}\$ 171,602 \\
\$ 242\end{array}$ \\
\hline $\begin{array}{l}85 \\
86\end{array}$ & $\begin{array}{l}50 \\
50\end{array}$ & $\begin{array}{l}\text { TITANATE ROTARY VALVE (150 CUFT/HR, 10", HASTELLOY C) } \\
\text { MOTOR-1.5 HP @ } 1800 \text { RPM }\end{array}$ & $\begin{array}{l}1 \mathrm{EA} \\
1 \mathrm{EA}\end{array}$ & $\begin{array}{r}72 \\
4\end{array}$ & $\begin{array}{r}72 \\
4\end{array}$ & $\begin{array}{l}\$ 48.34 \\
\$ 48.34\end{array}$ & $\begin{array}{r}\$ 3,481 \\
\$ 193\end{array}$ & $\begin{array}{c}\$ 60,000 \\
\text { INCL. }\end{array}$ & $\$ 60,000$ & $\begin{array}{l}\$ 0.00 \\
\$ 0.00\end{array}$ & $\begin{array}{l}\text { so } \\
\text { so }\end{array}$ & $\begin{array}{l}\$ 0.00 \\
\$ 0.00\end{array}$ & $\begin{array}{l}\text { \$o } \\
\text { \$0 }\end{array}$ & $\begin{array}{l}\$ 63,481 \\
\$ 193.37\end{array}$ & $\begin{aligned} \$ 63,481 \\
\$ 193\end{aligned}$ \\
\hline 88 & 50 & $\begin{array}{l}\text { HEAVY BLACK LIQUOR MIX TANK ( } 12 \Phi \times 30^{\prime} \text { L, 55,000 GAL } \\
316 \text { SS })\end{array}$ & $1 \mathrm{EA}$ & 360 & 360 & $\$ 48.34$ & $\$ 17,403$ & $\$ 143,000$ & $\$ 143,000$ & $\$ 0.00$ & \$0 & $\$ 0.00$ & $\$ 0$ & $\$ 160,403$ & $\$ 160,403$ \\
\hline
\end{tabular}




\begin{tabular}{|c|c|c|c|c|c|c|c|c|c|c|c|c|c|c|c|}
\hline $\begin{array}{l}\text { LINE } \\
\text { NO. }\end{array}$ & $\begin{array}{l}\text { JE } \\
\text { PRIME } \\
\text { CODE }\end{array}$ & $\begin{array}{l}\text { AREA } 001 \\
\text { TITANATE SYSTEM } \\
\text { DESCRIPTION }\end{array}$ & QTY. UNIT & $\begin{array}{l}\text { W.H.I } \\
\text { UNIT }\end{array}$ & $\begin{array}{l}\text { TOTAL } \\
\text { W.H.'s } \\
\end{array}$ & $\begin{array}{l}\text { cost/ } \\
\text { W.H. }\end{array}$ & $\begin{array}{l}\text { TOTAL } \\
\text { DIRECT } \\
\text { LABOR }\end{array}$ & $\begin{array}{l}\text { PROCESS } \\
\text { EQUIPMENT } \\
\text { UNIT COST } \\
\end{array}$ & $\begin{array}{c}\text { TOTAL } \\
\text { PROCESS } \\
\text { EQUIPMENT }\end{array}$ & $\begin{array}{l}\text { MATERIAL } \\
\text { UNIT COST } \\
\end{array}$ & $\begin{array}{c}\text { TOTAL } \\
\text { MATERIAL }\end{array}$ & $\begin{array}{l}\text { SUB } \\
\text { CONTRACT } \\
\text { UNIT COST } \\
\end{array}$ & $\begin{array}{c}\text { TOTAL } \\
\text { SUB } \\
\text { CONTRACTS } \\
\end{array}$ & $\begin{array}{l}\text { UNIT } \\
\text { COST }\end{array}$ & $\begin{array}{l}\text { TOTAL ALL } \\
\text { COSTS }\end{array}$ \\
\hline $\begin{array}{l}89 \\
90\end{array}$ & $\begin{array}{l}50 \\
50\end{array}$ & & & & & & & $\$ 15,000$ & $\$ 15,000$ & $\$ 0.00$ & $\$ 0$ & & & & \\
\hline 91 & $\begin{array}{l}50 \\
50\end{array}$ & MOTOR-150 HP @ 1800 RPM & $1 \mathrm{EA}$ & 64 & 64 & $\begin{array}{l}\$ 4.0 .34 \\
\$ 48.34\end{array}$ & 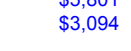 & $\$ 4,400$ & $\$ 4,400$ & $\begin{array}{l}\$ 0.00 \\
\$ 0.00\end{array}$ & $\$ 0$ & $\$ 0.00$ & so & $\$ \$ 7,494$ & $\$ 7,494$ \\
\hline 93 & $\begin{array}{l}50 \\
50\end{array}$ & $\begin{array}{l}\text { HEAVY BLACK LIQUOR TANK TRANSFER PUMP ( GOULD } 3175 \\
\text { 6X8-12,316L SS ) } \\
\text { MOTOR - } 50 \text { HP @ } 1800 \text { RPM }\end{array}$ & $\begin{array}{l}1 \mathrm{EA} \\
1 \mathrm{EA}\end{array}$ & $\begin{array}{l}48 \\
20\end{array}$ & $\begin{array}{l}48 \\
20\end{array}$ & $\begin{array}{l}\$ 48.34 \\
\$ 48.34\end{array}$ & $\begin{array}{r}\$ 2,320 \\
\$ 967\end{array}$ & $\begin{array}{r}\$ 25,279 \\
\$ 2,803\end{array}$ & $\begin{array}{r}\$ 25,279 \\
\$ 2,803\end{array}$ & $\begin{array}{l}\$ 0.00 \\
\$ 0.00\end{array}$ & $\begin{array}{l}\$ 0 \\
\$ 0\end{array}$ & $\begin{array}{l}\$ 0.00 \\
\$ 0.00\end{array}$ & $\begin{array}{l}\$ 0 \\
\$ 0\end{array}$ & $\begin{array}{r}\$ 27,599 \\
\$ 3,770\end{array}$ & $\begin{array}{r}\$ 27,599 \\
\$ 3,770\end{array}$ \\
\hline $\begin{array}{l}95 \\
96\end{array}$ & 50 & ALLOWANCE FOR CONCENTRATOR UPGRADE & 1 LOT & $s / C$ & 0 & $\$ 48.34$ & $\$ 0$ & \$o & $\$ 0$ & $\$ 0.00$ & so & $\$ 1,000,000$ & $\$ 1,000,000$ & $\$ 1,000,000$ & $\$ 1,000,000$ \\
\hline 98 & 50 & FREIGHT & 1 LOT & N/A & 0 & $\$ 48.34$ & \$o & W/EQUIP & \$o & $\$ 0.00$ & \$o & $\$ 0.00$ & so & $\$ 0.00$ & \$o \\
\hline $\begin{array}{l}99 \\
100\end{array}$ & 50 & SHIMS AND GROUT & 1 LOT & 135 & 135 & $\$ 48.34$ & $\$ 6,532$ & so & \$o & $\$ 177,605$ & $\$ 177,605$ & $\$ 0.00$ & so & $\$ 184,137$ & $\$ 184,137$ \\
\hline $\begin{array}{l}106 \\
107\end{array}$ & 50 & TOTAL - MAJOR EQUIPMENT & & & 5,540 & $\$ 48.34$ & $\$ 267,824$ & & $\$ 11,840,337$ & & $\$ 177,605$ & & $\$ 1,000,000$ & & $\$ 13,285,767$ \\
\hline 209 & & BUILDINGS & & & & & & & & & & & & & \\
\hline 211 & 55.380 & MOTOR CONTROL CENTER $\left(30^{\circ} \times 60^{\prime}\right)$ & $1,800 \mathrm{SF}$ & 4.58 & 8,241 & $\$ 42.04$ & $\$ 346,500$ & $\$ 0.00$ & so & $\$ 157.50$ & $\$ 283,500$ & $\$ 0.00$ & so & $\$ 350.00$ & $\$ 630,000$ \\
\hline $\begin{array}{l}217 \\
218\end{array}$ & 55.380 & TOTAL - BUILDINGS & $1,800 \mathrm{SF}$ & 4.58 & 8,241 & $\$ 42.04$ & $\$ 346,500$ & & so & & $\$ 283,500$ & & so & & $\$ 630,000$ \\
\hline $\begin{array}{l}219 \\
257\end{array}$ & & CONCRETE & & & & & & & & & & & & & \\
\hline $\begin{array}{l}258 \\
263\end{array}$ & 56 & FACTORED FROM INSTALLED PROCESS EQUIPMENT COST & 1 LOT & 6,320 & 6,320 & $\$ 42.04$ & $\$ 265,715$ & so & $\$ 0$ & $\$ 132,858$ & $\$ 132,858$ & $\$ 0$ & so & $\$ 398,573$ & $\$ 398,573$ \\
\hline $\begin{array}{l}204 \\
265\end{array}$ & 56 & TOTAL - CONCRETE & $421 \mathrm{cr}$ & 15.00 & 6,320 & $\$ 42.04$ & $\$ 265,715$ & & $\$ 0$ & & $\$ 132,858$ & & so & & $\$ 398,573$ \\
\hline $\begin{array}{l}267 \\
279\end{array}$ & & STRUCTURAL STEEL & & & & & & & & & & & & & \\
\hline $\begin{array}{l}280 \\
302\end{array}$ & 58 & FACTORED FROM INSTALLED PROCESS EQUIPMENT COST & 1 LOT & 2,289 & 2,289 & $\$ 43.53$ & $\$ 99,643$ & so & $\$ 0$ & $\$ 163,016$ & $\$ 163,016$ & $\$ 0$ & so & $\$ 262,660$ & $\$ 262,660$ \\
\hline 304 & 58 & TOTAL - STRUCTURAL STEEL & 57 TON & 40 & 2,289 & $\$ 43.53$ & $\$ 99,643$ & & $\$ 0$ & & $\$ 163,016$ & & so & & $\$ 262,660$ \\
\hline $\begin{array}{l}306 \\
340\end{array}$ & & PIPING & & & & & & & & & & & & & \\
\hline $\begin{array}{l}341 \\
375\end{array}$ & 62 & FACTORED FROM INSTALLED PROCESS EQUIPMENT COST & 1 LOT & 27,482 & 27,482 & $\$ 48.34$ & $\$ 1,328,577$ & so & so & $\$ 1,299,348$ & $\$ 1,299,348$ & \$0 & so & $\$ 2,627,925$ & $\$ 2,627,925$ \\
\hline 377 & 62 & TOTAL - PIPING, AVG. ø 12" & 7,852 LF & 3.78 & 29,642 & $\$ 48.34$ & $\$ 1,432,965$ & & $\$ 0$ & & $\$ 1,326,399$ & & so & & $\$ 2,759,363$ \\
\hline $\begin{array}{l}379 \\
391\end{array}$ & & INSTRUMENTATION & & & & & & & & & & & & & \\
\hline 404 & 64 & FACTORED FROM INSTALLED PROCESS EQUIPMENT COST & 1 LOT & 8,980 & 8,980 & $\$ 44.38$ & $\$ 398,573$ & $\$ 1,328,577$ & $\$ 1,328,577$ & $\$ 398,573$ & $\$ 398,573$ & $\$ 0$ & so & $\$ 2,125,723$ & $\$ 2,125,723$ \\
\hline $\begin{array}{l}405 \\
406 \\
407\end{array}$ & 64 & TOTAL - INSTRUMENTATION & & & 8,980 & $\$ 44.38$ & $\$ 398,573$ & & $\$ 1,328,577$ & & $\$ 398,573$ & & so & & $\$ 2,125,723$ \\
\hline $\begin{array}{l}408 \\
409\end{array}$ & & ELECTRICAL & & & & & & & & & & & & & \\
\hline 411 & 65 & 3450KVA SUBSTATION & 1 EA & 170 & 170 & $\$ 44.38$ & $\$ 7,545$ & $\$ 140,000$ & $\$ 140,000$ & $\$ 0.00$ & so & $\$ 0.00$ & so & $\$ 147,545$ & $\$ 147,545$ \\
\hline 413 & 65 & 2400V SWITCHGEAR & 1 LOT & 40 & 40 & $\$ 44.38$ & $\$ 1,775$ & $\$ 65,000$ & $\$ 65,000$ & $\$ 0.00$ & so & $\$ 0.00$ & so & $\$ 66,775$ & $\$ 66,775$ \\
\hline 415 & 65 & 1500KVA SUBSTATION & $1 \mathrm{EA}$ & 120 & 120 & $\$ 44.38$ & $\$ 5,326$ & $\$ 67,000$ & $\$ 67,000$ & $\$ 0.00$ & so & $\$ 0.00$ & so & $\$ 72,326$ & $\$ 72,326$ \\
\hline $\begin{array}{l}416 \\
417 \\
418\end{array}$ & 65 & $15 \mathrm{KV}$ SWITCH & 1 EA & 40 & 40 & $\$ 44.38$ & $\$ 1,775$ & $\$ 28,000$ & $\$ 28,000$ & $\$ 0.00$ & so & $\$ 0.00$ & so & $\$ 29,775$ & $\$ 29,775$ \\
\hline
\end{tabular}




\begin{tabular}{|c|c|c|c|c|c|c|c|c|c|c|c|c|c|c|c|c|}
\hline $\begin{array}{l}\text { LINE } \\
\text { NO. }\end{array}$ & $\begin{array}{c}\text { JE } \\
\text { PRIME } \\
\text { CODE } \\
\end{array}$ & $\begin{array}{c}\text { AREA } 001 \\
\text { TITANATE SYSTEM } \\
\text { DESCRIPTION } \\
\end{array}$ & QTY. & UNIT & $\begin{array}{l}\text { W.H.I } \\
\text { UNIT }\end{array}$ & $\begin{array}{l}\text { TOTAL } \\
\text { W.H.'s } \\
\end{array}$ & $\begin{array}{l}\text { COST/ } \\
\text { W.H. }\end{array}$ & $\begin{array}{l}\text { TOTAL } \\
\text { DIRECT } \\
\text { LABOR } \\
\end{array}$ & $\begin{array}{l}\text { PROCESS } \\
\text { EQUIPMENT } \\
\text { UNIT COST } \\
\end{array}$ & $\begin{array}{c}\text { TOTAL } \\
\text { PROCESS } \\
\text { EQUIPMENT }\end{array}$ & $\begin{array}{l}\text { MATERIAL } \\
\text { UNIT COST }\end{array}$ & $\begin{array}{c}\text { TOTAL } \\
\text { MATERIAL }\end{array}$ & $\begin{array}{c}\text { SUB } \\
\text { CONTRACT } \\
\text { UNIT COST }\end{array}$ & $\begin{array}{c}\text { TOTAL } \\
\text { SUB } \\
\text { CONTRACTS } \\
\end{array}$ & $\begin{array}{l}\text { UNIT } \\
\text { COST } \\
\end{array}$ & $\begin{array}{c}\text { TOTAL ALL } \\
\text { COSTS }\end{array}$ \\
\hline $\begin{array}{l}419 \\
420\end{array}$ & 65 & 480V SWITCHGEAR & 1 & EA & 90 & 90 & $\$ 44.38$ & $\$ 3,994$ & $\$ 49,000$ & $\$ 49,000$ & $\$ 0.00$ & $\$ 0$ & $\$ 0.00$ & $\$ 0$ & $\$ 52,994$ & $\$ 52,994$ \\
\hline $\begin{array}{l}421 \\
422\end{array}$ & 65 & LOW VOLTAGE MOTOR CONTROL CENTERS & 20 & EA & 12.00 & 240 & $\$ 44.38$ & $\$ 10,652$ & $\$ 1,500$ & $\$ 30,000$ & $\$ 0.00$ & $\$ 0$ & $\$ 0.00$ & $\$ 0$ & $\$ 2,033$ & $\$ 40,652$ \\
\hline $\begin{array}{l}423 \\
423 \\
424\end{array}$ & 65 & MEDIUM VOLTAGE MOTOR CONTROL CENTERS & & EA & 16.00 & 48 & $\$ 44.38$ & $\$ 2,130$ & $\$ 17,000$ & $\$ 51,000$ & $\$ 0.00$ & $\$ 0$ & $\$ 0.00$ & $\$ 0$ & $\$ 17,710$ & $\$ 53,130$ \\
\hline $\begin{array}{l}425 \\
427\end{array}$ & 65 & MINOR ELECTRICAL - WIRING DEVICES & 88 & EA & 0.50 & 44 & $\$ 44.38$ & $\$ 1,953$ & $\$ 0.00$ & $\$ 0$ & $\$ 50.00$ & $\$ 4,400$ & $\$ 0.00$ & $\$ 0$ & $\$ 72.19$ & $\$ 6,353$ \\
\hline $\begin{array}{l}428 \\
431\end{array}$ & 65 & GROUND RODS / WIRE & 440 & LF & 0.10 & 44 & $\$ 44.38$ & $\$ 1,953$ & $\$ 0.00$ & $\$ 0$ & $\$ 3.50$ & $\$ 1,540$ & $\$ 0.00$ & $\$ 0$ & $\$ 7.94$ & $\$ 3,493$ \\
\hline $\begin{array}{l}432 \\
433\end{array}$ & 65 & WIRE AND CABLE & 12,500 & LF & 0.05 & 625 & $\$ 44.38$ & $\$ 27,739$ & $\$ 0.00$ & $\$ 0$ & $\$ 1.50$ & $\$ 18,750$ & $\$ 0.00$ & $\$ 0$ & $\$ 3.72$ & $\$ 46,489$ \\
\hline $\begin{array}{l}434 \\
437\end{array}$ & 65 & CONDUIT & 7,500 & $\mathrm{LF}$ & 0.15 & 1,125 & $\$ 44.38$ & $\$ 49,931$ & $\$ 0.00$ & $\$ 0$ & $\$ 3.75$ & $\$ 28,125$ & $\$ 0.00$ & $\$ 0$ & $\$ 10.41$ & $\$ 78,056$ \\
\hline $\begin{array}{l}438 \\
439\end{array}$ & 65 & TESTING AND STARTUP & & LOT & 129 & 129 & $\$ 44.38$ & $\$ 5,739$ & $\$ 0.00$ & $\$ 0$ & $\$ 0.00$ & $\$ 0$ & $\$ 0.00$ & $\$ 0$ & $\$ 5,739$ & $\$ 5,739$ \\
\hline $\begin{array}{l}440 \\
445\end{array}$ & 65 & FREIGHT & & LOT & N/A & 0 & $\$ 44.38$ & $\$ 0$ & $\$ 4,860$ & $\$ 4,860$ & $\$ 3,169$ & $\$ 3,169$ & $\$ 0.00$ & $\$ 0$ & $\$ 8,029$ & $\$ 8,029$ \\
\hline $\begin{array}{l}446 \\
472 \\
473 \\
474\end{array}$ & 65 & TOTAL - ELECTRICAL & 12,940 & LF & 0.21 & 2,715 & $\$ 44.38$ & $\$ 120,513$ & & $\$ 434,860$ & & $\$ 55,984$ & & $\$ 0$ & & $\$ 611,357$ \\
\hline 475 & & TOTAL - DIRECT COST & & & & 63,728 & $\$ 46.00$ & $\$ 2,931,733$ & & $\$ 13,603,774$ & & $\$ 2,537,935$ & & $\$ 1,000,000$ & & $\$ 20,073,442$ \\
\hline
\end{tabular}




\subsection{OPERATING AND MAINTENANCE COSTS}

The operating and maintenance costs for each option are estimated from the following sources of information:

- Chemicals usages from WinGEMS or spreadsheet mass balances

- Lime kiln fuel oil usage for HTBLG (Larson Study)

- Electricity usage based on total connected equipment horsepower times $80 \%$ for each case

- Chemicals, fuel oil, and electricity costs from current market pricing (August, 2006)

- Annual maintenance cost equal to $5 \%$ of capital cost

Table 8 shows the chemicals, fuel oil, and electricity costs used for the economics analysis based on 2006 prices.

\section{Table 8}

Chemicals, Fuel Oil, and Electricity Costs (2006)

\#6 Fuel Oil , \$/MMBtu

Electricity , \$/MWh

Borate, \$/mt

Titanium Dioxide, $\$ / m t$

Hydrochloric Acid, \$/mt

Sodium Hydroxide, $\$ / \mathrm{mt}$

\section{$\$ 8.51$}

$\$ 58.60$

$\$ 425.00$

$\$ 480.00$

$\$ 135.00$

$\$ 370.00$ 
Table 9 shows chemicals, fuel oil, and electricity usage or savings as compared to the base case.

\section{Table 9}

Annual Chemicals, Fuel Oil, and Electricity Usages

\begin{tabular}{rrr} 
& Borate & \multicolumn{1}{c}{ Titanate } \\
Fuel Oil Savings & 217,386 & $1,086,928 \mathrm{MMBtu} / \mathrm{yr}$ \\
Electricity Savings & 4,310 & $7,038 \mathrm{MWh} / \mathrm{yr}$ \\
Borate Usage & 1,177 & $\mathrm{mt} / \mathrm{yr}$ \\
Titanium Dioxide Usage & & $3,951 \mathrm{mt} / \mathrm{yr}$ \\
Hydrochloric Acid Usage & & $5,559 \mathrm{mt} / \mathrm{yr}$ \\
Sodium Hydroxide Usage & & $3,912 \mathrm{mt} / \mathrm{yr}$
\end{tabular}

Table 10 shows the costs or savings items for each option. Avoided cost savings are treated as positive cash flow. The annual maintenance cost for the base case is based on $5 \%$ of the capital cost of a new lime kiln and caustic plant of similar capacity. This capital cost is approximately $\$ 35,000,000$. 
Table 10

Annualized O\&M Costs

$\begin{array}{lcl} & \text { Annual } \$ \\ \text { Base } & \text { Borate Titanate }\end{array}$

\section{Avoided Cost Savings}

Avoided Lime Kiln Fuel Oil

$1,849,503 \quad 9,247,514$

Avoided Electricity Purchases

Total

$2,102,070 \quad 9,659,943$

\section{Direct Operating Costs}

Borate

500,288

Titanate

$1,896,391$

Hydrochloric Acid

750,454

Sodium Hydroxide

$1,447,375$

Incremental Waste Treatment Costs (.10 KW/lpm)

29,809

Operations \& Maintenance

$1,750,000$

$1,408,700 \quad 1,577,250$

Total

$1,750,000$

$1,908,988 \quad 5,701,279$

\subsection{ECONOMIC ANALYSIS}

\subsection{Approach and Assumptions}

Both the internal rate of return (IRR) and net present value (NPV) analyses were performed on each case and also performed relative to the base case. The key inputs to the analyses are the capital costs from Section 5 and the annualized operating and maintenance costs from Section 6 . Table 11 shows the economic assumptions used for the analyses. 


\section{Table 11}

\section{Economic Assumptions}

\section{Financial Parameters}

Annual Inflation Rate

$4.0 \%$

Debt Fraction of Capital

$50 \%$

Equity Fraction of Capital

$50 \%$

Interest Rate on Debt

$8.0 \%$

Return on Equity

$15 \%$

Resulting Discount Rate used for NPV calculations

$9.9 \%($ after tax)

Income Tax Rate (combined Federal \& State)

$40 \%$

Economic Life (years)

25

Depreciation Method

20-year MACRS rate schedule $^{1}$

Construction Time

$1 \mathrm{yr}$

Mill Assumptions

Annual Operating Hours

Annual O\&M Costs, \% of Capital Cost

$5 \%$

\section{Start-up Assumptions}

Year 1 of Operation

$100 \%$

(1 - Modified Accelerated Cost Recovery System (MACRS) per IRS Tax Code) 


\subsection{Economic Analysis Results}

The IRR and NPV cash flow analyses were performed for each case and for relative comparison to the HTBLG base case. The annualized materials and energy flows used in the analyses are shown above in Table 9. The detailed cash flow calculations are shown in Appendix F.

As shown in Table 12, sensitivity analyses were performed for capital cost, fuel and electricity costs since these variables are subject to some volatility in the current and future economic environment.

Table 12

Economic Analysis Results Summary

TOTAL NET CASH FLOW

\begin{tabular}{lcccc} 
& \multicolumn{2}{c}{ Stand-Alone } & \multicolumn{2}{c}{ Relative to Base } \\
& $\begin{array}{l}\text { IRR } \\
(\%)\end{array}$ & $\begin{array}{c}\text { NPV } \\
\text { (\$ million) }\end{array}$ & $\begin{array}{l}\text { IRR } \\
(\%)\end{array}$ & $\begin{array}{c}\text { NPV } \\
\text { (\$ million) }\end{array}$ \\
Base - HTBLG & N/A & -14.6 & N/A & 0 \\
Borate & $135 \%$ & 1.4 & N/A & 16.1 \\
Titanate & $15.9 \%$ & 10.6 & $23.9 \%$ & 25.2
\end{tabular}

Considering the stand-alone NPVs over the total project life of 25 years, the titanate option clearly has the best NPV of $\$ 10.6 \mathrm{MM}$ primarily from the substantial fuel savings over the base case. The borate option has a high stand-alone IRR of $135 \%$ due to the minimal capital investment required. The borate option still achieves $20 \%$ of the fuel savings of the titanate option. Relative to the base case the titanate option is more economically attractive with an NPV of $\$ 25.2 \mathrm{MM}$ and an IRR of $23.9 \%$.

The titanate carries some technical risks though because it is a new technology. The performance of titanate as a direct causticizing agent and the subsequent acid purging of NPEs was proven successful on the lab scale. Some basic assumptions are made about the titanate char physical properties in order to configure the process presented in this report. The actual performance of the process must be determined through pilot plant trials to refine the process configuration and minimize risk. Hence, the capital cost could vary depending on the final process scope from pilot plant work. Borate, on the other hand, has been proven effective in conventional Tomlison based recovery cycles but only for partial auto-causticization. 
Below are sensitivity charts that show how the capital cost variance affects the economics.

Figure 6

\section{Electrical \& Capital Cost Sensitivity}

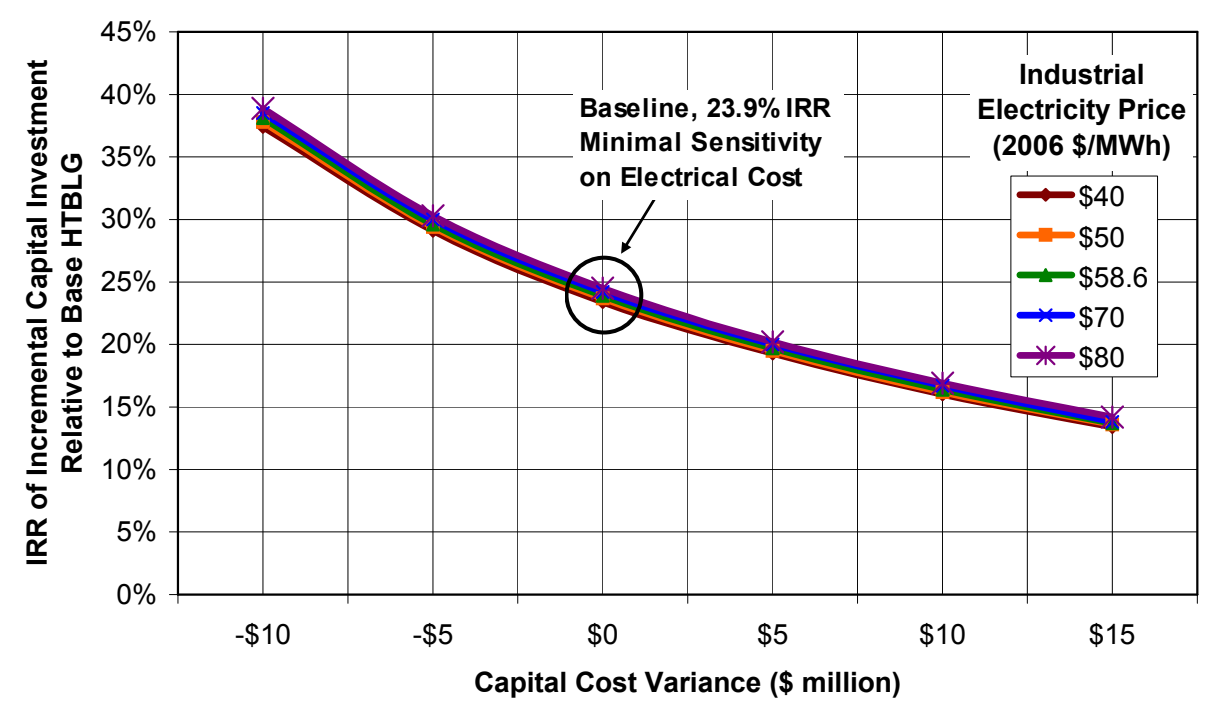

Figure 7

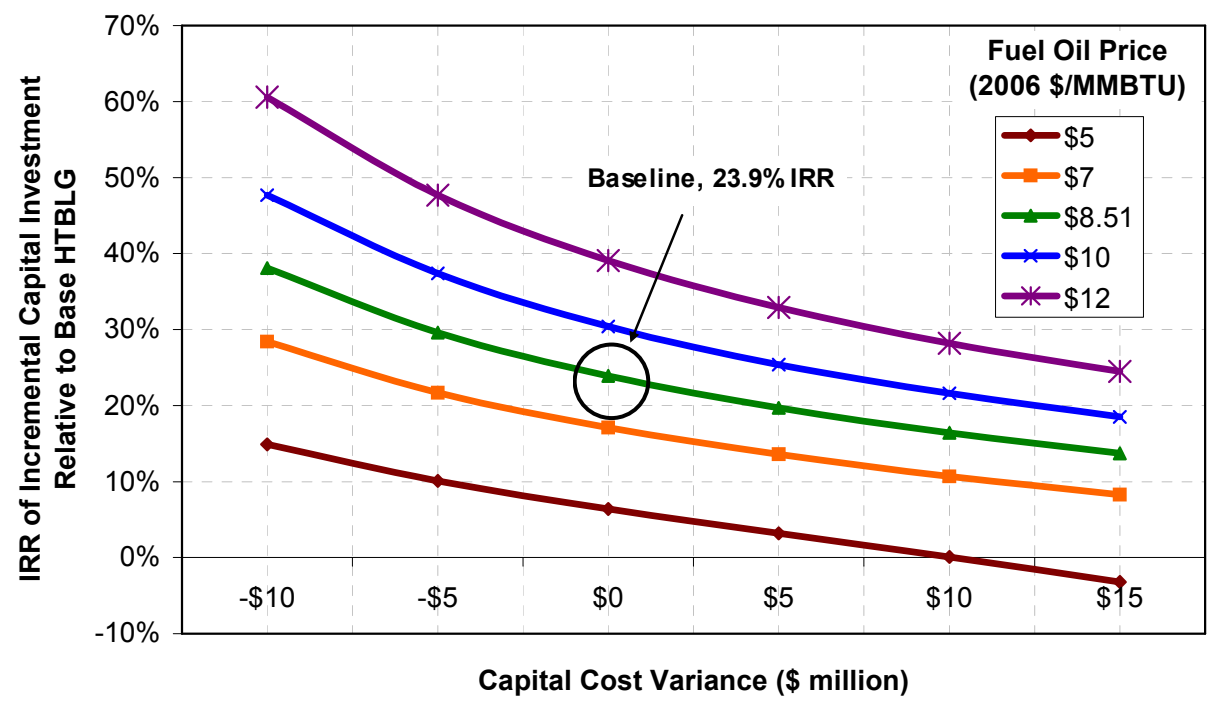


Figure 6 shows IRR sensitivity to titanate capital cost variance. Also, the industrial electricity price was varied only around the baseline $\$ 0$ cost variance to check the sensitivity spread. Industrial electricity price variance has minimal effect on the IRR because it is simply not a large portion of the incremental operating cost. The fuel oil cost by far outweighs the effect of electricity cost. The IRR decreases from about $24 \%$ to $14 \%$ as the capital cost increases by $\$ 15 \mathrm{MM}$.

Figure 7 shows IRR sensitivity to titanate capital cost variance at varying fuel oil prices. Fuel oil price variance has a significant effect on the IRR. If fuel oil price rises to $\$ 10$ per MMBTU, then the IRR will increase from $23.9 \%$ to $31 \%$. On the other hand a significant drop in fuel oil price will severely negate the economics of titanate as well. Therefore, fuel price trends must be carefully analyzed to predict economic performance for future projects.

\subsection{Summary and Conclusions}

The borate and titanate options are both effective auto and direct causticizing agents, respectively. Borate carries minimal capital investment and provides attractive payback and economics by alleviating the additional burden on the lime cycle that HTBLG causes and by saving some kiln fuel oil cost.

Titanate can replace up to $100 \%$ of the lime cycle and provide equal white liquor quality. This has been demonstrated on the lab scale. By assuming physical properties of the titanate being similar to lime mud we can extrapolate to a mill-scale process utilizing three staged agitated leaching tanks for reaction residence time followed by disc filtration. Acid leaching of a final titanate side stream achieves the required NPE purge of metals. Potassium remains in the system either as potassium titanate or potassium hydroxide and carbonate. This poses no problem without a Tomlison recovery boiler in the system. An additional hydraulic burden is put on the black liquor concentrator system due to the high flow rate of suspended titanate solids to $50 \%$ black liquor. It is not known exactly what the performance and maintenance impact will be with this additional $40 \%$ mass flow load increase. The additional suspended solids could enhance the crystallization process and reduce fouling for $80 \%$ solids liquor production by providing sites for crystallization to take place rather than on heat transfer surface areas. On the other hand, the added abrasive ness of the concentrated black liquor may pose a maintenance risk to the process equipment.

Titanate bears no advantage to the mill water balance except when compared to a conventional lime kiln wet scrubber system. In this case there is a 40 to $50 \%$ reduction in water lost to the sewer or atmosphere with the titanate option.

The titanate option economics are very favorable. The titanate recovery system is estimated at about $\$ 32 \mathrm{MM}$ with an NPV and IRR, relative to the base case, of $\$ 25.2 \mathrm{MM}$ and $23.9 \%$. The main issue is scale-up from lab results. Pilot plant testing is required to firm up the process scope and capital cost estimate. 


\subsection{Abbreviations}

Black Liquor Solids

Bone Dry

Electrostatic Precipitator

Engineer, Procure, Construct

Hardwood

High Temperature Black Liquor Gasification

Higher Heating Value

Internal Rate of Return

Liters Per Minute

Machine Dry

Metric Ton

Metric Tons Per Day

Net Present Value

Non-Process Elements

Short Tons Per Day

Softwood

Total Installed Cost

Total Titratable Alkali
BLS

bd

ESP

EPC

HW

HTBLG

HHV

IRR

Ipm

md

$\mathrm{mt}$

mtpd

NPV

NPEs

stpd

SW

TIC

TTA 
IPST - Georgia Tech

Jacobs Job No. 16BD7500

Atlanta, Georgia

February 26, 2007

Mill Integration Study Report

Rev. 1

\subsection{APPENDICES}

APPENDIX A - PROCESS FLOW DIAGRAMS 


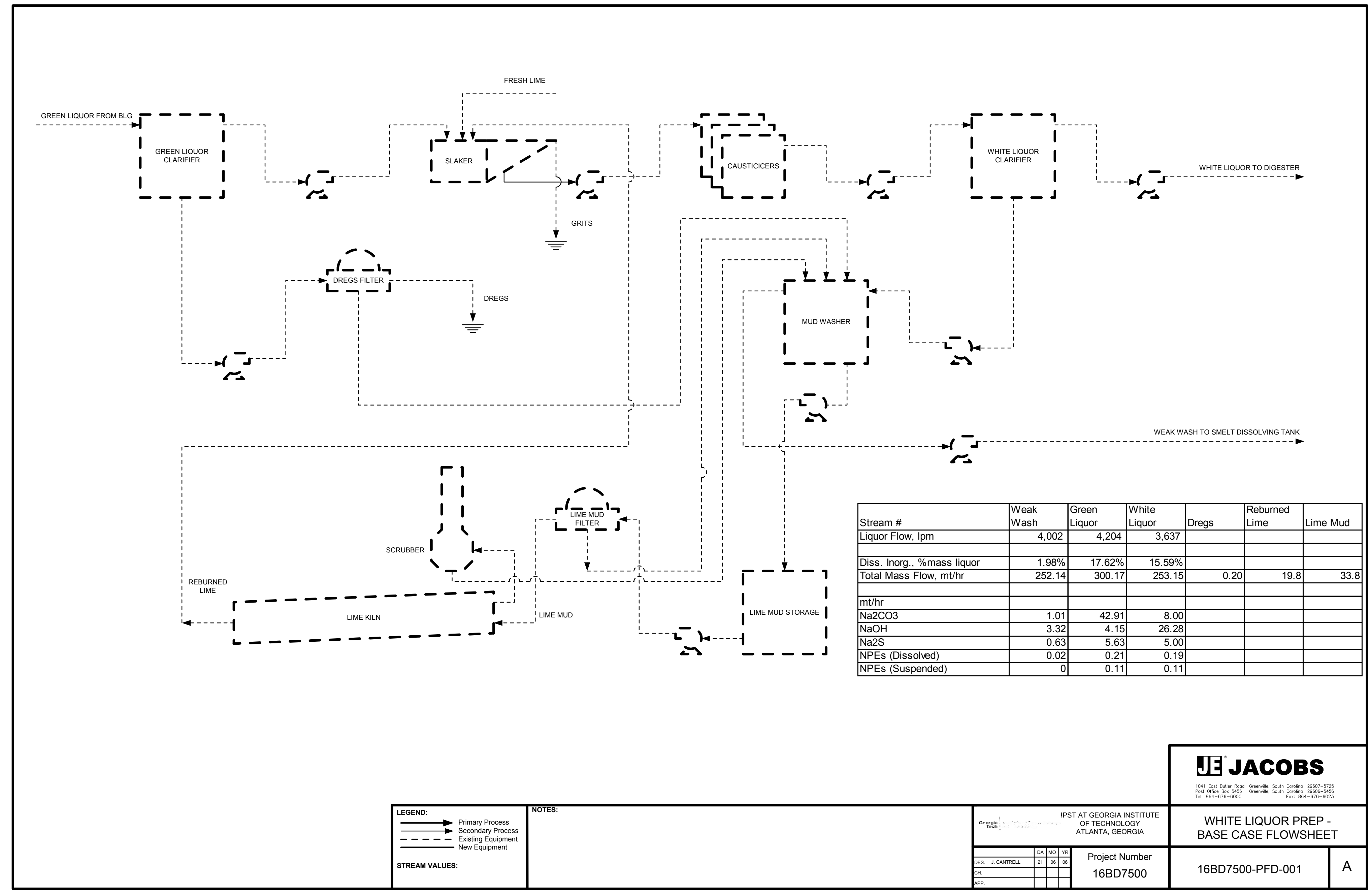




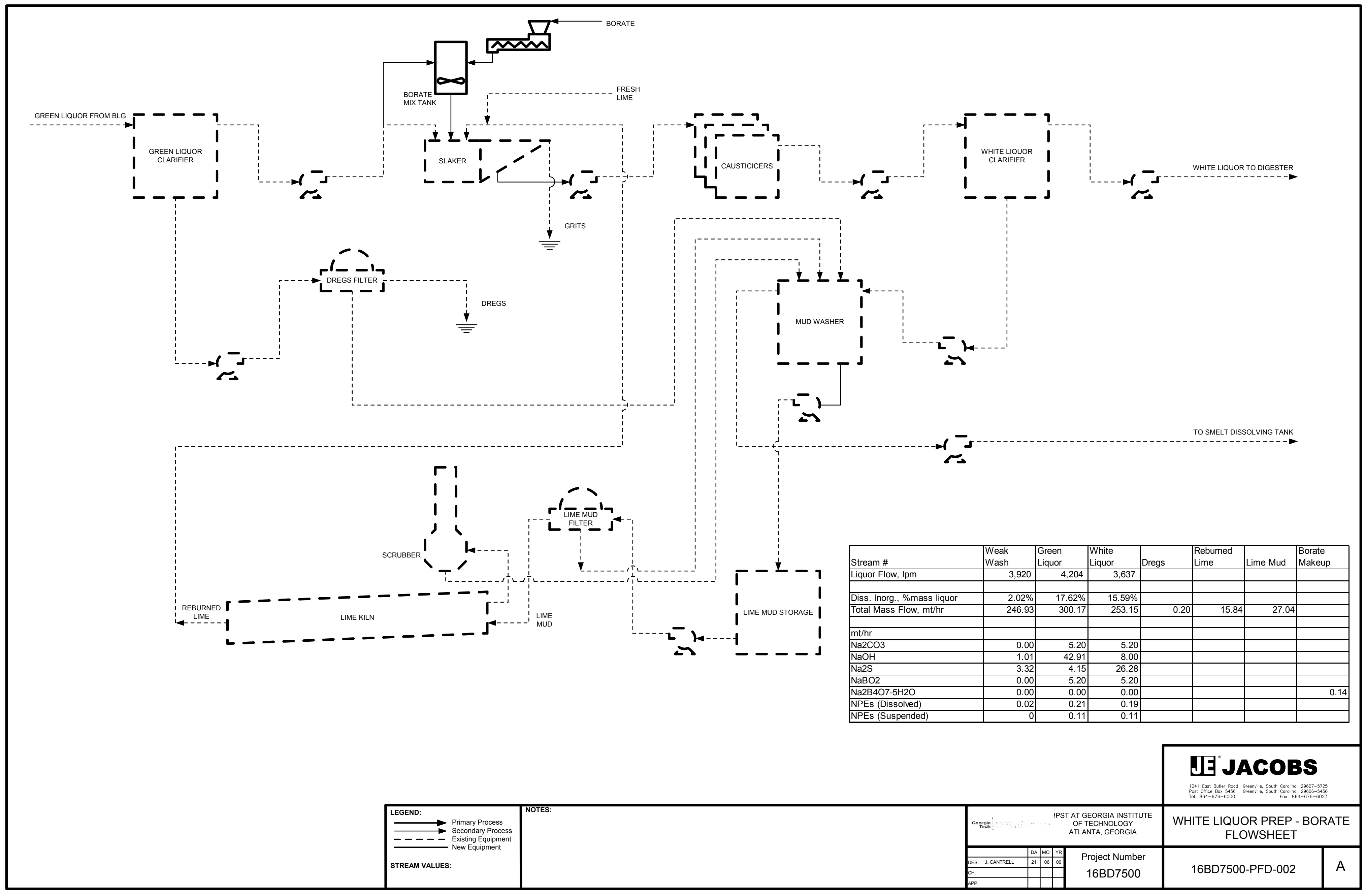




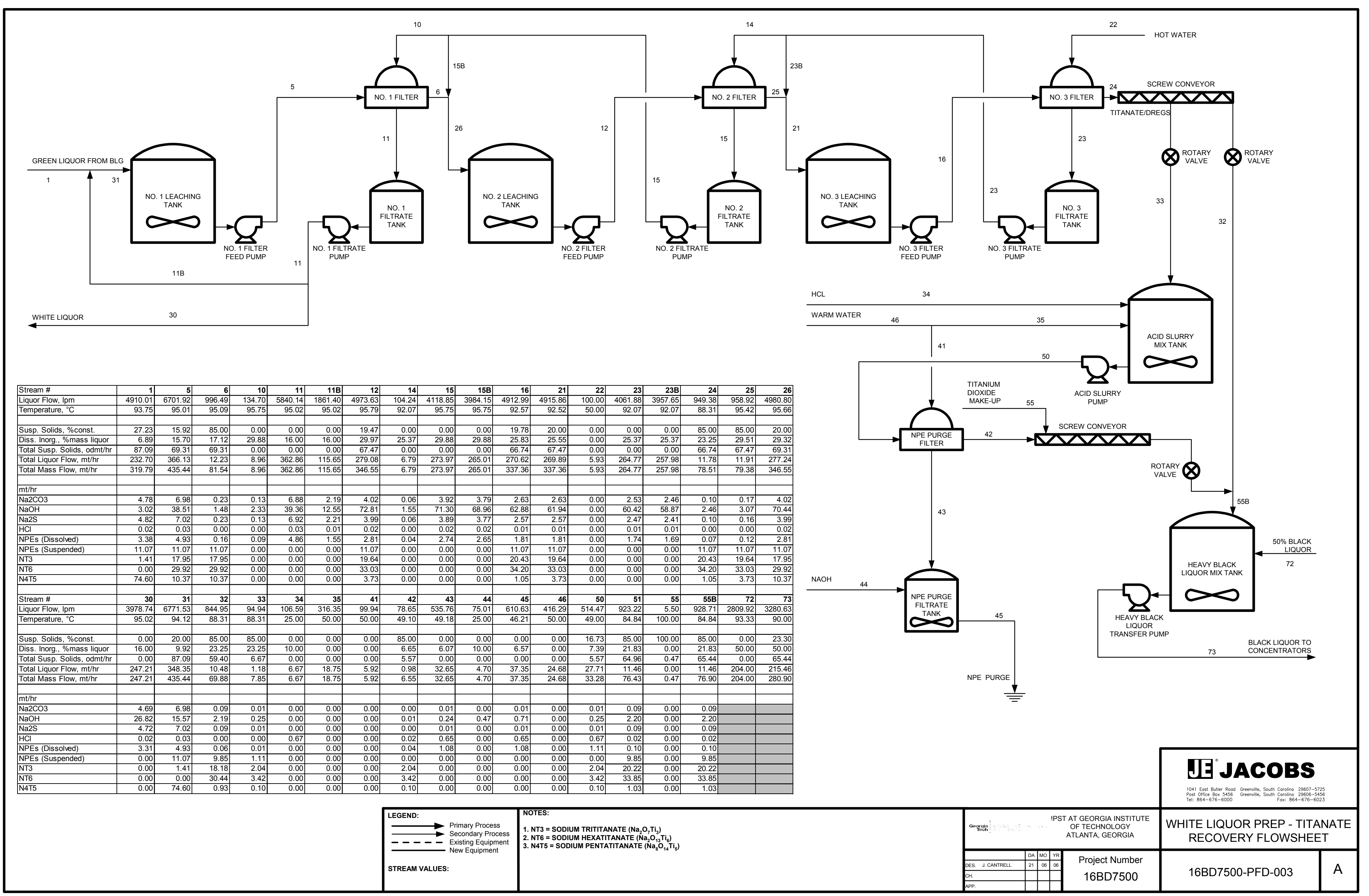




\section{APPENDIX B - TYPICAL BASE MILL CAUSTIC ROOM POWER \\ Equipment \\ Connected HP \\ (450 tpd RBL)}

Green Liquor Clarifiers $\quad 7.5$

GLC Overflow Pumps $\quad 80$

GLC Underflow Pump 60

Green Liquor Storage Tank Pump 25

Slaker Scrubber Pump $\quad 15$

Slaker Scrubber Recirc. Pump $\quad 60$

Slaker Agitator 40

Slaker Grits Screw 3

Nos. 1 - 4 Causticizers Agitators 120

Causticized Liquor Pump $\quad 75$

Dregs Precoat Filter 5

Dregs Filter Discharge Screw $\quad 25$

Dregs Filtrate Pump $\quad 7.5$

Dregs Filter Dump Tank Pump

Dregs Filter Purge Pump $\quad 125$

Dregs Filter Vacuum Pump

Weak Wash Pump $\quad 50$

Weak Wash Agitator 4

White Liquor Clarifier 4

WLC Overflow Pump 50

WLC Underflow Pump $\quad 60$

Mud Washer 4

Weak Wash Pump $\quad 25$

Washed Mud Pump $\quad 40$

Mud Storage Agitators $\quad 35$

Lime Mud Recirc. Pump 25

LM to Dregs Filter Precoat Pump 20

LM to Mud Filter Precoat Pump 20

Mud Filter Feed Pumps $\quad 60$

LM Filter $\quad 60$

LM Filter Vacuum Pumps $\quad 800$

LM Filter Filtrate Pumps $\quad 40$

LM Filter Belt Conveyors $\quad 15$

LM Filter Screw Conveyors $\quad 40$

Mill Water Pump $\quad 75$

Kiln Feed Conveyor $\quad 125$

Kiln ID Fan $\quad 900$

Kiln Scrubber Recirc. Pump 80

Kiln Sump Pump $\quad 30$

Kiln Drive 200

Kiln Trunion Cooling Water Pump

Kiln Primary Air Fan $\quad 55$

Kiln Secondary Air Fan $\quad 55$

Atomizing Air Blower $\quad 40$

Purchase Lime Conveyor $\quad 10$

Hot Lime Drag Conveyor $\quad 20$

Lime Crusher 5

Lime Bucket Elevator $\quad 10$

$\begin{array}{ll}\text { Total Connected Power } & 3700\end{array}$

Total Connected Power @ 525 tpd RBL 4320

Total Operating Power (80\% of connected) 3460

Titanate System Connected Power 2910

Total Operating Power (80\% of connected) 2330

$\begin{array}{ll}\text { Difference } & 1130\end{array}$ 
APPENDIX C - BORATE STOICHIOMETRY

Sodium tetraborate (makeup) reacts with sodium carbonate in the gasifier:

$\mathrm{Na}_{2} \mathrm{~B}_{4} \mathrm{O}_{7}+5 \mathrm{Na}_{2} \mathrm{CO}_{3} \rightarrow 4 \mathrm{Na}_{3} \mathrm{BO}_{3}+5 \mathrm{CO}_{2}$

Sodium is bound up by sodium metaborate within the gasifier:

$2 \mathrm{NaBO}_{2}+\mathrm{Na}_{2} \mathrm{CO}_{3} \leftrightarrow \mathrm{Na}_{4} \mathrm{~B}_{2} \mathrm{O}_{7}+\mathrm{CO}_{2}$

$\mathrm{NaBO}_{2}+\mathrm{Na}_{2} \mathrm{CO}_{3} \leftrightarrow \mathrm{Na}_{3} \mathrm{BO}_{3}+\mathrm{CO}_{2}$

The caustic is later recovered by hydrolysis:

$\mathrm{Na}_{3} \mathrm{BO}_{3}+\mathrm{H}_{2} \mathrm{O} \leftrightarrow 2 \mathrm{NaOH}(\mathrm{aq})+\mathrm{NaBO}_{2}(\mathrm{aq})$

Borate is soluble and circulates with the pulping liquor

The amount of sodium tetraborate pentahydrate makeup required is as follows per U.S. Borax:

\section{$\frac{\text { Ton Neobor Makeup }}{\text { Ton of Lime Replaced }}=1.3 \times \mathrm{A} \times \mathrm{B} \times \mathrm{C} / \mathrm{D}$}

where: $\mathrm{A}=$ Lime Availability, wt $\%$ of $\mathrm{CaO}$ in lime

$$
\begin{aligned}
& =90 \% \\
& =81 \% \\
& =3 \%
\end{aligned}
$$$$
\mathrm{B}=\text { White Liquor Causticity , mole } \%
$$$$
\mathrm{C}=\text { Borate Loss Rate, } \% \text { of Borate Used }
$$

Borate loss rate can be assumed equal to $\mathrm{Na}$ loss rate from the liquor cycle. However, the $\mathrm{Na}$ loss rate has to be expressed as a percentage of the total amount of $\mathrm{Na}$ passed through digester (or in circulation).

$$
\mathrm{D}=\text { Borate AC Reaction Efficiency, } \% \quad=80 \%
$$


APPENDIX D - TITANATE STOICHIOMETRY

$>$ Sodium is bound up by titanates within the gasifier:

$\mathrm{Na}_{2} \mathrm{CO}_{3}+3 \mathrm{TiO}_{2}(\mathrm{~s}) \leftrightarrow \mathrm{Na}_{2} \mathrm{O} \cdot 3 \mathrm{TiO}_{2}(\mathrm{~s})+\mathrm{CO}_{2}(\mathrm{~g})$

$7 \mathrm{Na}_{2} \mathrm{CO}_{3}+5\left(\mathrm{Na}_{2} \mathrm{O}-3 \mathrm{TiO}_{2}\right)(\mathrm{s}) \leftrightarrow 3\left(4 \mathrm{Na}_{2} \mathrm{O}-5 \mathrm{TiO}_{2}\right)(\mathrm{s})+7 \mathrm{CO}_{2}(\mathrm{~g})$

$\mathrm{Na}_{2} \mathrm{O}-6 \mathrm{TiO}_{2}(\mathrm{~s})+\mathrm{Na}_{2} \mathrm{CO}_{3}(\mathrm{~s}) \leftrightarrow 2\left(\mathrm{Na}_{2} \mathrm{O}-3 \mathrm{TiO}_{2}\right)(\mathrm{s})+\mathrm{CO}_{2}(\mathrm{~g})$

[Abbreviated NT3, N4T5, NT6]

$>$ The caustic is later recovered by hydrolysis:

$3\left(4 \mathrm{Na}_{2} \mathrm{O}-5 \mathrm{TiO}_{2}\right)(\mathrm{s})+7 \mathrm{H}_{2} \mathrm{O} \leftrightarrow 14 \mathrm{NaOH}(\mathrm{aq})+5\left(\mathrm{Na}_{2} \mathrm{O}-3 \mathrm{TiO}_{2}\right)(\mathrm{s})$

$2\left(\mathrm{Na}_{2} \mathrm{O}-3 \mathrm{TiO}_{2}\right)(\mathrm{s})+\mathrm{H}_{2} \mathrm{O} \leftrightarrow 2 \mathrm{NaOH}(\mathrm{aq})+\mathrm{Na}_{2} \mathrm{O}-6 \mathrm{TiO}_{2}$ (s) (65\%) 
IPST - Georgia Tech

Atlanta, Georgia

Mill Integration Study Report
Jacobs Job No. 16BD7500

February 26, 2007

Rev. 1

\section{APPENDIX E - WINGEMS TITANATE BALANCE FLOWSHEET}




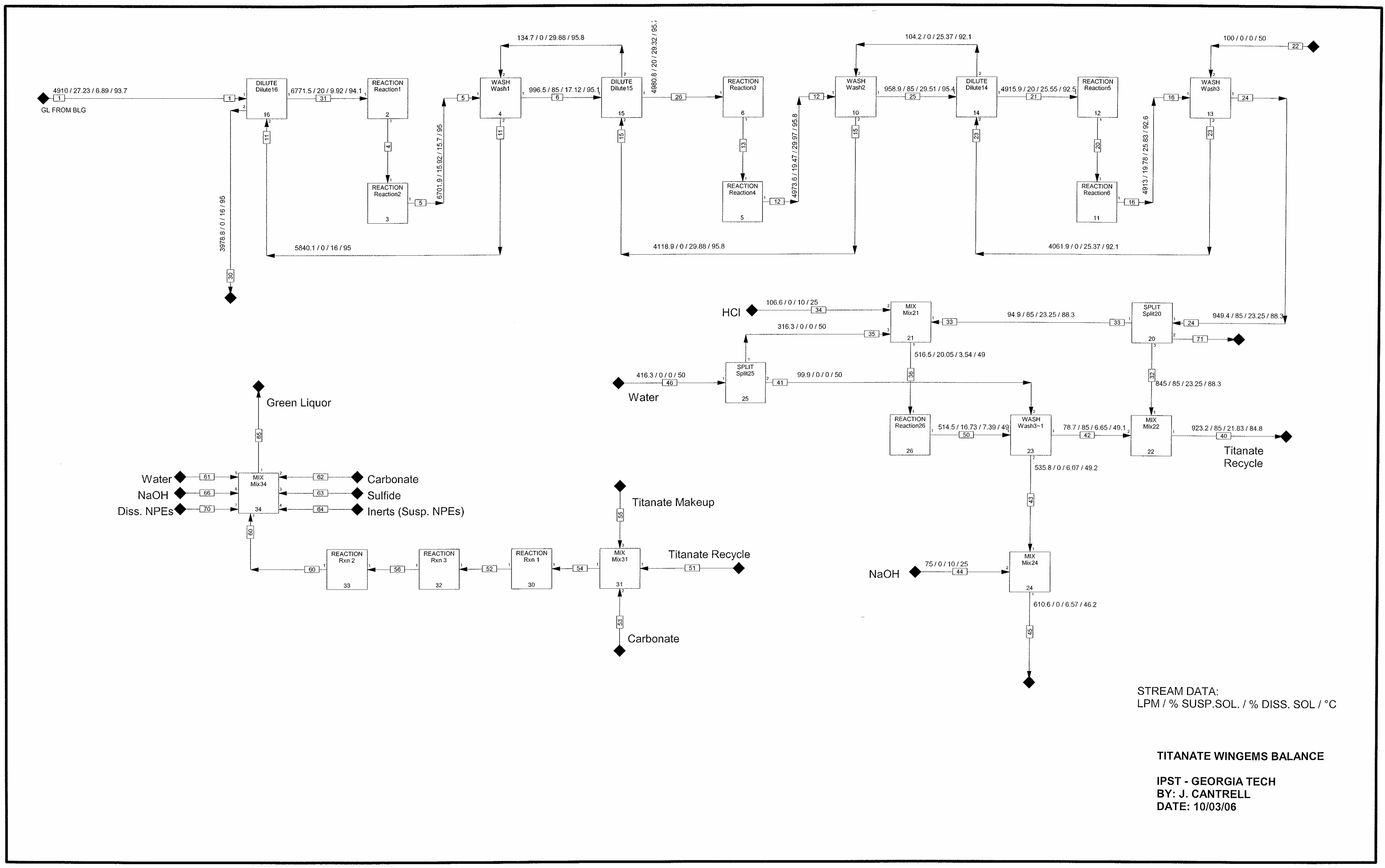




\section{APPENDIX F - DETAILED FINANCIAL ANALYSES}




\section{Total Net Cash Flow}

\section{Base Case}

NPV (\$ million)

IRR

Borate

NPV (\$ million)

IRR

Titanate

NPV (\$ million)

IRR

Total Net Cash Flow Variance from Base

Borate

NPV of Variance (\$ million)

IRR on Variance

Titanate

NPV of Variance (\$ million)

IRR on Variance

$(1,200,518) \quad(1,248,771)$

$(1,298,750)$

$(1,350,540)$

$(1,403,909)$

$(1,458,026)$

$(1,514,354)$

$(1,572,981)$

$(1,633,995)$

$(1,697,505)$

$\begin{array}{llll}(14.6) & (620,146) \quad(1,009,005) \quad(955,381)\end{array}$

(904,432)

$(856,036) \quad(810,097)$

$(766,516)$

(1)

$(685,147)$

$(647,513)$

$(578,464)$

$(546,813)$

$\begin{array}{rrrrrr} & (89,921) & 118,033 & 122,659 & 127,499 & 132,566 \\ 1.4 & (89,921) & 107,400 & 101,555 & 96,054 & 90,874 \\ 135 \% & & & & & \\ & & & & & \\ & & & & & \end{array}$

137,864

143,402

149,233
77,069

155,498
73,071

162,007
69,271

168,769

175,796

183,097

85,993

81,390

45

$10.6 \quad(16,302,077) \quad 1,843,575$

$1,730,269$

$1,628,436$

$1,536,841$

$2,330,857$

$2,428,281$

$2,542,567$

$2,697,876$

$1,267,770$

$2,858,186$

3,023,697

$1,176,417$

$3,194,744$

$1,130,997$

$3,371,163$

$15.9 \%$

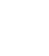

\begin{tabular}{|c|c|c|c|c|c|c|c|c|c|c|c|c|c|}
\hline & 530,224 & $1,226,929$ & $1,276,569$ & $1,328,018$ & $1,381,337$ & $1,436,614$ & $1,493,942$ & $1,553,142$ & $1,613,524$ & $1,676,361$ & $1,741,751$ & $1,809,791$ & $1,880,601$ \\
\hline 16.1 & 530,224 & $1,116,405$ & $1,056,937$ & $1,000,486$ & 946,910 & 896,090 & 847,906 & 802,098 & 758,218 & 716,784 & 677,656 & 640,699 & 605,793 \\
\hline & $(15,681,932)$ & $3,134,985$ & $3,243,731$ & $3,362,061$ & $3,490,688$ & $3,629,607$ & $3,778,821$ & $3,946,476$ & $4,155,903$ & $4,372,541$ & $4,596,679$ & $4,828,739$ & $5,068,668$ \\
\hline 25.2 & $(15,681,932)$ & $2,852,580$ & $2,685,650$ & $2,532,868$ & $2,392,876$ & $2,263,972$ & $2,144,718$ & $2,038,101$ & $1,952,917$ & $1,869,625$ & $1,788,411$ & $1,709,461$ & $1,632,757$ \\
\hline
\end{tabular}




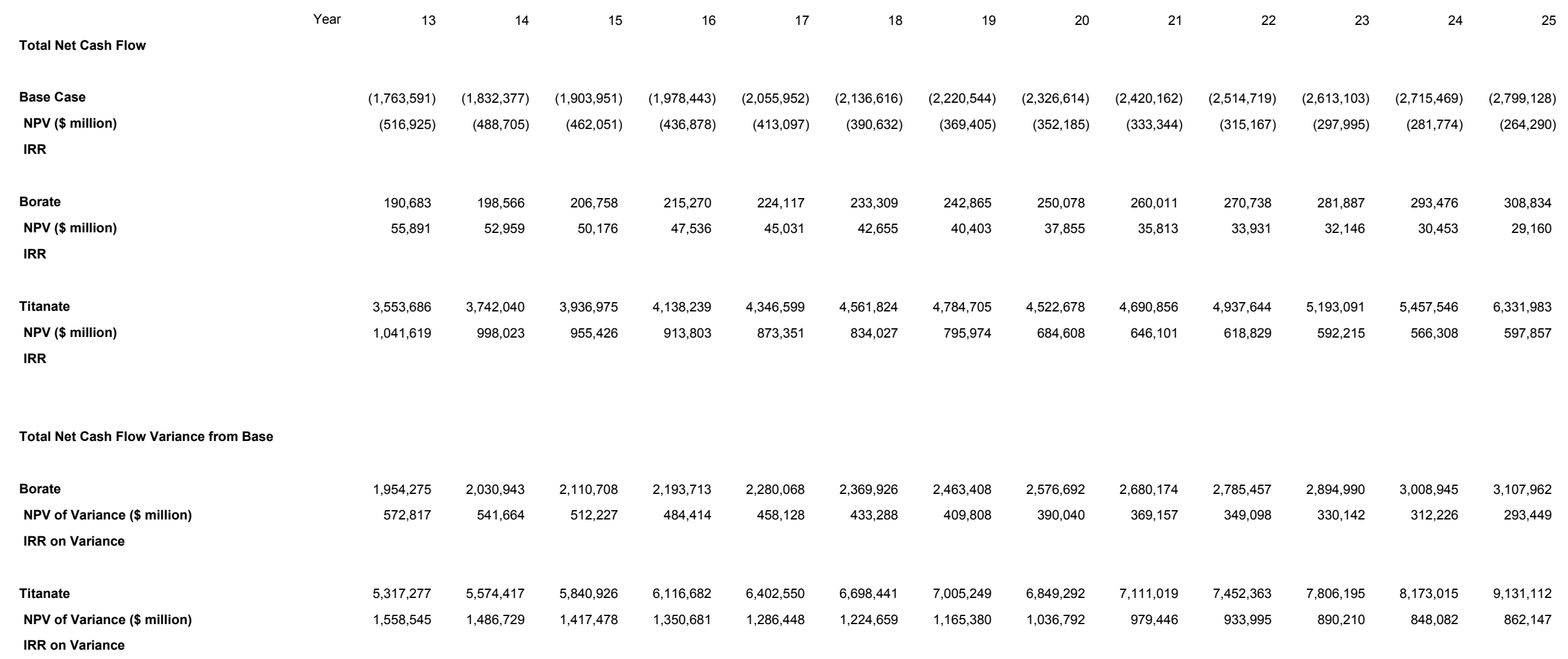




\section{Base Case}

\section{Avoided Cost Savings}

Subtotal - Avoided Cost Savings

Direct Operating Costs

Operations \& Maintenance

Subtotal - Operating Costs

Financing

Interest

Principal

Cumulative Principal

Subtotal - Financing

\section{Total Expenses Before Taxes}

Income Taxes

Total Expenses After Taxes

Net Cash Flow from Operations

Equity Capital Invested

Total Net Cash Flow

Discount Factor

NPV (\$ million)

IRR

Total Capital Invested

Discount Rate
Year

$1,892,800$

$1,968,512$

$2,047,252$

$2,129,143$

$2,214,308$

$2,302,881$

$1,968,512$

$2,047,252$

$2,129,143$

$2,214,308$

$2,302,881$

2,394,996

$2,490,796$

$2,490,796$

$2,590,427$

$2,590,427$

$2,694,045$

$2,694,045$

$2,801,806$

$2,801,806$

24,000

\section{2,240}

40,320

\section{8,400}

70,080

48,000

24,000

24,000

24,000

36,480

\section{4,560}

32,640

24,000

24,000

\section{0,720}

24,000

144,000

168,000

192,000

216,000

54,720

240,000

52,800

26,880

24,000

264,000

50,880

24,960

24,000

288,000

48,960

23,040

$70,080 \quad 1,888,160$

$1,959,040 \quad 2,032,832$

$2,109,652$

$2,189,623$

$2,272,868$

$2,359,521$

$2,449,716$

$2,543,596$

$2,641,307$

$2,743,005$

$2,848,846$

$(49,934) \quad(779,264)$

$(805,130)$

(832,3

$20,146 \quad 1,108,8$

$1,153,9$

$1,200,518$

$1,248,77$

(955,611)

$(991,690)$

$(1,029,241)$

$(1,068,32$

$(1,109,010)$

$(1,151,342)$

$(20,146)$

$(1,108,896)$

$(1,153,910)$

$(1,200,518)$

$(1,248,771)$

$(600,000)$

$(620,146)$

(14.6)

1.0

$(620,146)$

$(1,108,896)$
1.1
$(1,009,005)$

$(1,153,910)$
1.2
$(955,381)$

$(1,200,518)$
1.3
$(904,432)$

$(1,248,771)$
1.5
$(856,036)$

$(1,298,750)$
1.6
$(810,097)$

$(1,350,540)$
1.8

$(1,40$

$(1,403,909)$
1.9

$(1,458,026)$

$1,200,000$ 


\section{Base Case}

\begin{tabular}{|c|c|c|c|c|c|c|c|c|c|c|c|}
\hline & Year & 16 & 17 & 18 & 19 & 20 & 21 & 22 & 23 & 24 & 25 \\
\hline \multicolumn{12}{|l|}{ Avoided Cost Savings } \\
\hline Subtotal - Avoided Cost Savings & 0 & 0 & 0 & 0 & 0 & 0 & 0 & 0 & 0 & 0 & 0 \\
\hline \multicolumn{12}{|l|}{ Direct Operating Costs } \\
\hline Operations \& Maintenance & $3,151,651$ & $3,277,717$ & $3,408,826$ & $3,545,179$ & $3,686,986$ & $3,834,466$ & $3,987,844$ & $4,147,358$ & $4,313,252$ & $4,485,782$ & $4,665,214$ \\
\hline Subtotal - Operating Costs & $3,151,651$ & $3,277,717$ & $3,408,826$ & $3,545,179$ & $3,686,986$ & $3,834,466$ & $3,987,844$ & $4,147,358$ & $4,313,252$ & $4,485,782$ & $4,665,214$ \\
\hline \multicolumn{12}{|l|}{ Financing } \\
\hline Interest & 17,280 & 15,360 & 13,440 & 11,520 & 9,600 & 7,680 & 5,760 & 3,840 & 1,920 & 0 & \\
\hline Principal & 24,000 & 24,000 & 24,000 & 24,000 & 24,000 & 24,000 & 24,000 & 24,000 & 24,000 & 24,000 & \\
\hline Cumulative Principal & 384,000 & 408,000 & 432,000 & 456,000 & 480,000 & 504,000 & 528,000 & 552,000 & 576,000 & 600,000 & \\
\hline Subtotal - Financing & 41,280 & 39,360 & 37,440 & 35,520 & 33,600 & 31,680 & 29,760 & 27,840 & 25,920 & 24,000 & \\
\hline Total Expenses Before Taxes & $3,192,931$ & $3,317,077$ & $3,446,266$ & $3,580,699$ & $3,720,586$ & $3,866,146$ & $4,017,604$ & $4,175,198$ & $4,339,172$ & $4,509,782$ & $4,665,214$ \\
\hline Total Expenses After Taxes & $1,903,951$ & $1,978,443$ & $2,055,952$ & $2,136,616$ & $2,220,544$ & $2,326,614$ & $2,420,162$ & $2,514,719$ & $2,613,103$ & $2,715,469$ & $2,799,128$ \\
\hline Net Cash Flow from Operations & $(1,903,951)$ & $(1,978,443)$ & $(2,055,952)$ & $(2,136,616)$ & $(2,220,544)$ & $(2,326,614)$ & $(2,420,162)$ & $(2,514,719)$ & $(2,613,103)$ & $(2,715,469)$ & $(2,799,128)$ \\
\hline \multicolumn{12}{|l|}{ Equity Capital Invested } \\
\hline Total Net Cash Flow & $(1,903,951)$ & $(1,978,443)$ & $(2,055,952)$ & $(2,136,616)$ & $(2,220,544)$ & $(2,326,614)$ & $(2,420,162)$ & $(2,514,719)$ & $(2,613,103)$ & $(2,715,469)$ & $(2,799,128)$ \\
\hline Discount Factor & 4.1 & 4.5 & 5.0 & 5.5 & 6.0 & 6.6 & 7.3 & 8.0 & 8.8 & 9.6 & 10.6 \\
\hline NPV (\$ million) & $(462,051)$ & $(436,878)$ & $(413,097)$ & $(390,632)$ & $(369,405)$ & $(352,185)$ & $(333,344)$ & $(315,167)$ & $(297,995)$ & $(281,774)$ & $(264,290)$ \\
\hline
\end{tabular}

Total Capital Invested

Discount Rate 


\section{Avoided Cost Savings}

Avoided Lime Kiln Fuel Oil

Avoided Electricity Purchases

Subtotal - Avoided Cost Savings

Direct Operating Costs

Borate

Operations \& Maintenance

Subtotal - Operating Costs

Financing

Interest

Principal

Cumulative Principal

Subtotal - Financing

Total Expenses Before Taxes

Income Taxes

\section{Total Expenses After Taxes}

Net Cash Flow from Operations

Equity Capital Invested

Total Net Cash Flow

Discount Factor

NPV (\$ million)

Total Capital Invested

Discount Rate
$1,923,483$

262,669

$2,186,152$

$2,000,422$

$2,080,439$

273,176

$2,273,598$

284,103

$2,364,542$

$2,163,657$

295,467

$2,459,124$

$2,250,203$

307,286

$2,557,489$

319,577

$2,659,789$

$2,433,820$

332,361

$2,766,180$

$2,531,172$
345,655

$2,876,827$

$2,632,419$

359,481

$2,737,716$

373,860

$3,111,576$

$2,847,225$

388,815

$3,236,040$

$520,300 \quad 541,112$

$1,465,048$

$1,523,650$

562,756

585,267

608,677

633,024

658,345

684,679

$1,985,348$

$1,647,980$

$1,713,899$

$1,782,455$

$1,853,753$

$1,927,903$

712,066

740,549

$2,085,220$

770,171

2,168,629

$2,717,086$

$2,825,769$

$2,938,800$

$2,255,374$

$3,056,352$

3,480

3,480

10,162

10,162

$\begin{array}{lll}(7,240) & 72,888 & 76,573\end{array}$

$2,921 \quad 2,068,120$

$2,150,940$

$2,237,043$

122,659

127,499

132,566

5,290
3,480

5,011

4,733

3,480

4,454

$$
3,480
$$

3,480

27,840

8,213

3,480

3,480

3,480

34,800

7,656

3,898

3,480

38,280

38,280
7,378

3,619

3,480

41,760

7,099

$2,520,311$

$2,620,517$

$2,724,742$

$2,833,14$

109,66

(2)

(2)

92,416

96,636

100,813

105,152

$2,419,625$

$2,516,387$

$2,616,94$

137,864

143,402

149,233

155,498

175,79

$(87,000)$

(89,92

1.0

$(89,921)$

118,033

122,659
1.2
101,555

127,499
1.3
96,054

137,864
1.6
85,993

143,402
1.8
81,390

149,233

155,498
2.1
73,071
162,007
2.3
69,271

168,769

175,796

77,069

73,071

2.6

2.8

62,235

183,097

3.1

58,980
174,000

1.099 


\section{Avoided Cost Savings}

Avoided Lime Kiln Fuel Oil

Avoided Electricity Purchases

Subtotal - Avoided Cost Savings

\section{Direct Operating Costs}

Borate

Operations \& Maintenance

$3,079,558$

420,542

$3,202,741$

$3,330,850$

$3,464,084$

$3,602,648$

$3,746,753$

$3,896,624$

$4,052,489$

$4,214,588$

$4,383,172$

$4,558,499$

$4,740,838$

$4,930,472$

$3,500,100$

$3,640,104$

$3,785,709 \quad 3,937,137$

$4,094,622$

$4,258,407$

$4,428,744$

$4,605,893$

$4,790,129$

$4,981,734$

$5,181,004$

833,017

866,338

900,991

937,031

974,512

$1,013,492$

$1,054,032$

$1,096,193$

$1,140,041$

$1,185,643$

$1,233,069$

$1,282,391$

$1,333,687$

$2,345,589$

$2,439,413 \quad 2,536,989$

$2,638,469 \quad 2,744,007$

$2,853,768$

$2,967,918$

$3,086,635$

$3,210,101$

$3,338,505$

$3,472,045$

$3,610,927$

$3,755,364$

$3,437,980 \quad 3,575,499 \quad 3,718,519 \quad 3,867,260 \quad 4,021,951$

$4,350,142$

$4,524,147$

$4,705,113$

$4,893,318$

Financing

Interest

Principal

Cumulative Principal

Subtotal - Financing

Total Expenses Before Taxes

Income Taxes

Total Expenses After Taxes

3,062
3,480
48,720
6,542

$2,784 \quad 2,506$

$2,227 \quad 1,949$

$\begin{array}{llll}3,480 & 3,480 & 3,480 & 3,480\end{array}$

1,670

52,200

3,480

1,392

1.114

835
3,480

$\begin{array}{rrr}557 & 278 & 0 \\ 3,480 & 3,480 & 3,480 \\ 80,040 & 83,520 & 87,000 \\ 4,037 & 3,758 & 3,480\end{array}$

$3,185,148$

$312,014-2,443,966$

0,507

5,429

66,120

3,480

76,560

4,037

$4,896,798$

$5,089,051$

$124,269 \quad 129,525 \quad 134$

140,661

146,558

152,687

159,056

175,661

182,812

190,245

197,970

205,889

$3,309,417$

$4,025,098$

$4,185,879$

$4,355,815$

$4,530,11$

$4,710,996$

$4,899,11$

$5,094,768$

$5,294,940$

190,683

$\begin{array}{lll}198,566 & 206,758 & 215,270\end{array}$

224,117

233,309

242,865

250,078

260,011

270,738

281,887

293,476

308,834

Equity Capital Invested

Total Net Cash Flow

Discount Factor

NPV (\$ million)

IRR

Total Capital Invested

Discount Rate 
Avoided Cost Savings

Avoided Lime Kiln Fuel Oil

Avoided Electricity Purchases

Subtotal - Avoided Cost Savings

\section{Direct Operating Costs}

Titanium Dioxide

Hydrochloric Acid

Sodium Hydroxide

Incremental Waste Treatment Costs

Operations \& Maintenance

Subtotal - Operating Costs

\section{Financing}

Interest

Principal

Cumulative Principal

Subtotal - Financing

\section{Total Expenses Before Taxes}

Income Taxes

Total Expenses After Taxes

Net Cash Flow from Operations

Equity Capital Invested

Total Net Cash Flow

Discount Factor

NPV (\$ million)

IRR

Total Capital Invested

Discount Rate
Year

$428,925 \quad 446,082$

$10,402,196$

$10,448,194$

463,926

$10,866,122$

$10,818,284$

11

$10,046,340$

$11,300,767$

501,782

$11,752,797$

$1,701,056$

(1)

$12,169,098$

8

$12,655,862$

$12,222,909$

$12,711,826$

$13,220,299$

$13,162,096$
587,014

13

$13,688,580$

610,495

$13,749,111$

$14,299,075$

$4,236,124$

634,914

$14,871,038$

$1,972,143 \quad 2,051,028$

$2,133,069$

811,700

$2,218,392$

$2,307,128$

$2,399,413$

$2,495,390$

$1,505,306$

$1,565,518$

$1,628,139$

877,935

913,053

949,575

$2,495,390$
987,558

$2,595,205$

(2,

30,999

32,239

33,529

34,870

$1,760,995$

$1,831,435$

$1,904,692$

$1,027,060$

$1,980,880$

$1,068,142$

$1,640,340$

$6,166,440$

$6,413,098$

$1,845,159$

$1,918,966$

$6,936,406$

$1,995,724$

$7,213,863$

$2,075,553$

$7,502,417$

$2,158,576$

$7,802,514$

42,425

$2,244,919$

$8,114,614$

$1,211,328$
630,900

$1,160,856$

$1,110,384$

630,900
$1,842,228$

630,900

$1,059,912$

$1,009,440$

\section{8,968}

$1,261,800$

630,900

630,900

630,900

630,900

908,490

\section{8,024}

$1,842,228$

$1,791,756$

$1,741,284$

$1,690,812$

$3,154,500$

$3,785,400$

630,900

$4,416,300$

630,900

$5,047,200$

807,552

630,900

$5,678,100$

\section{7,080}

630,900

$6,309,000$

$1,539,396$

$1,488,924$

$1,438,452$

$1,387,980$

$9,240,966$

$(1,312,651)$

299,226

$9,907,724$

$8,103,910$

$8,309,962$

$8,526,274$

$8,753,259$

$8,991,341$

600,670

748,888

895,666

$529,577 \quad 8,020,251$

$8,358,373$

$8,704,579$

$9,058,849$

$9,421,940$

$1,281,45$

$9,502,594$

$(529,577) \quad 2,026,089$

$2,089,821$

$2,161,543$

$2,241,917$

$(15,772,500)$

$(16,302,077) \quad 2,026,089$

10.6

1.0

1.1

$2,089,821$

$2,161,543$

$2,241,917$

$1,730,269$

$1,628,436$

$1,536,841$

$2,330,857$

$2,428,281$

$1,453,875$

$1,378,202$

$2,542,567$

1.9

$1,313,072$

$2,697,876$
2.1

$1,267,770$

$2,858,186$
2.3
$1,222,113$

$3,023,697$

2.6
$1,176,417$

$3,194,744$
2.8

$1,130,997$
$31,545,000$

1.099 


\section{Avoided Cost Savings}

Avoided Lime Kiln Fuel OI

Avoided Electricity Purchases

Subtotal - Avoided Cost Savings

\section{Direct Operating Costs}

Titanium Dioxide

Hydrochloric Acid

Sodium Hydroxide

Incremental Waste Treatment Costs

Operations \& Maintenance

Subtotal - Operating Costs

Financing

Interest

Principal

Cumulative Principal

Subtotal - Financing

Total Expenses Before Taxes

Income Taxes

Total Expenses After Taxes

\section{Net Cash Flow from Operations}

Equity Capital Invested

Total Net Cash Flow
Discount Factor
NPV (\$ million)
IRR

IRR

Total Capital Invested

Discount Rate $\begin{array}{lllll}15,397,791 & 16,013,703 & 16,654,251 & 17,320,421 & 18,013,238\end{array}$$$
686,723 \quad 714,192
$$$$
742,760
$$

772,470

$$
803,369
$$

$18,733,767$

$16,084,515$

$16,727,895$

$17,397,011 \quad 18,092,892$

$18,816,607$

835,504

$19,483,118$

$20,262,443$

$21,072,941$

$21,915,858$

$20,352,042 \quad 21,166,124$

$22,012,769$

$22,893,280$

$23,704,192$

$24,652,360$

(969,271

$3,157,464$

$3,283,762$

$3,415,113$

$3,551,717$

$3,693,786$

$3,841,538$

(1)

$1,299,558$

$1,351,541$

$1,405,602$

$1,461,826$

$1,520,300$

$3,995,199$

$4,155,007$

4,321,207

2,710,971

$\begin{array}{r}58,061 \\ \hline\end{array}$

$2,932,187$

$3,049,474$

$1,644,356$

$3,171,453$

$1,710,130$

$3,298,311$

$4,494,056$

$1,778,535$

$3,430,244$

70,640

$2,731,287 \quad 2,840,538$

$2,954,160$

$3,072,326$

$3,195,219$

62,799

65,311

67,924

$9,492,951$

$9,872,669$

$10,267,576$

$12,011,612$

12,492076

$12,991,759$

13511,429

$$
630,900
$$

504,720

454,248

$8,832,600$

630,900

403776

353,304

$1,186,092$

$9,463,500$

630,900

630,900

630,900

\section{0}

$10,679,043$

$11,008,289$

$11,356,200$

630,900
$11,987,100$

630,900

201,888

\section{1,416}

$1,851,786$

$1,977,566$

$11,352,724$

$11,712,955$

984,204

933,732

$12,618,000$

630,900

630,900

630,900

630,900

$15,141,600$

782,316

731,844

681,372

$883,260 \quad 832,788$

$13,774,075$

$14,243,273$

$14,733,259$

$$
2,483,359
$$$$
\text { (2,894,872 }
$$

$12,530,8$

$12,985,85$

$3,742,040$

0

$2,380,394$

\section{$2,524,089$}

\section{$2,672,465$}

$3,318,582$

$16,643.446$

\section{$3,547,838$}

$3,712,363$

$3,882,66$

$18,615,92$

4,138,239

$4,346,599$

$4,561,824$

$4,784,705$

$4,522,678$

$3,553,686$

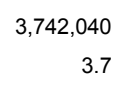

$3,936,975$

$4,138,239$

$1,041,619$

998,023

955,426

4.5
913,803

$4,346,599$
5.0
873,351

$4,561,824$
5.5
834,027

$4,784,705$
6.0
795,974

$4,522,678$
6.6
684,608
$4,690,856$

4,937,644

$5,193,09$

$4,690,856$
7.3
646,101

$4,937,644$
8.0
618,829

$5,193,091$
8.8
592,215

$5,457,546$

$6,331,983$

$592,215 \quad 566,308$

10.6

597,857 